\section{Pacific Northwest}

National Laboratory

Operated by Battelle for the

U.S. Department of Energy

\title{
200-BP-1 Prototype Hanford Barrier Annual Monitoring Report for Fiscal Year 2004
}

\author{
A. L. Ward \\ J. K. Linville \\ J. M. Keller \\ G.H. Seedahmed
}

January 2005

Prepared for the U.S. Department of Energy under Contract DE-AC05-76RL01830 


\title{
DISCLAIMER
}

This report was prepared as an account of work sponsored by an agency of the United States Government. Neither the United States Government nor any agency thereof, nor Battelle Memorial Institute, nor any of their employees, makes any warranty, express or implied, or assumes any legal liability or responsibility for the accuracy, completeness, or usefulness of any information, apparatus, product, or process disclosed, or represents that its use would not infringe privately owned rights. Reference herein to any specific commercial product, process, or service by trade name, trademark, manufacturer, or otherwise does not necessarily constitute or imply its endorsement, recommendation, or favoring by the United States Government or any agency thereof, or Battelle Memorial Institute. The views and opinions of authors expressed herein do not necessarily state or reflect those of the United States Government or any agency thereof.

\author{
PACIFIC NORTHWEST NATIONAL LABORATORY \\ operated by \\ BATTELLE \\ for the \\ UNITED STATES DEPARTMENT OF ENERGY \\ under Contract DE-ACO5-76RL01830
}




\section{0-BP-1 Prototype Hanford Barrier Annual Monitoring Report for Fiscal Year 2004}
A. L. Ward
J. K. Linville
J. M. Keller
G. H. Seedahmed

January 2005

Prepared for

the U.S. Department of Energy

under Contract DE-AC05-76RL01830

Pacific Northwest National Laboratory

Richland, Washington 99352 


\section{Summary}

In FY 2004, monitoring of the prototype Hanford barrier focused on barrier stability, vegetative cover, evidence of plant and animal intrusion, and the main components of the water balance. Monitored water-balance components included precipitation, runoff, storage, drainage, and deep percolation. Precipitation in FY 2004 was 26 percent less than in FY 2003 but was still higher than normal. The seasonal distribution in precipitation was also different from the previous year with a 43-percent reduction in spring precipitation and a 46-percent increase in summer precipitation. The cumulative amount of water received from October 1994, through September 2004, was 2,559.58 $\mathrm{mm}$ on the northern half of the barrier, which is the formerly irrigated treatment, and $1,886.71 \mathrm{~mm}$ on the southern non-irrigated treatments. Water storage continued to show a cyclic pattern, increasing in the winter and declining in the spring and summer to a lower limit of about $100 \mathrm{~mm}$ in response to evapotranspiration. The $600-\mathrm{mm}$ design storage has never been exceeded. Total drainage from the soil-covered plots range from $2.9 \mathrm{E}-4$ $\mathrm{mm}$ to $0.22 \mathrm{~mm}$ or 0.00360 .004 percent of precipitation. Side-slope drainage was much higher at 20.96 2.3 percent of precipitation from the gravel and 18.665 .1 percent from the riprap. There was no runoff from the barrier, but runoff from the BY tank farm following a thunderstorm in May eroded a 45-inchdeep channel into the structural fill at the toe of the riprap slope. Above-asphalt and below-asphalt moisture measurements show no evidence of deep percolation of water. Topographic surveys were conducted on the barrier surface, including the two settlement gauges and 12 creep gauges on the riprap slope using aerial photogrammetry (AP) and a global positioning system (GPS). Comparing the aerial photogrammetry (AP) and global positioning system (GPS) surveys with the traditional survey shows the barrier and side slopes to be stable. Both AP and GPS show potential for considerable cost savings without any loss in accuracy. A relatively high coverage of native plants still persists after the initial revegetation in 1994. The formerly irrigated treatments continue to show greater cover of grasses and litter than the non-irrigated treatments. On the formerly irrigated treatments, the mean cover class was 25 to 50 percent for both grasses and shrubs. On the non-irrigated treatments, the mean cover class was 5 to 25 percent from grasses and 25 to 50 percent for shrubs. Species diversity of the vegetative community appears to have stabilized over the past several years. In addition to 12 of 17 species present in 2003 being present in 2004, two additional species were encountered. Sagebrush continues to flourish with shrubs along the perimeter showing higher biomass yield than the interior shrubs. There is evidence of sagebrush seedlings recruitment but not of rabbitbrush; the presence of gray rabbitbrush appears is declining as the barrier surface continues to stabilize. Use of the barrier surface by insects and small mammals is also evident. Small mammal burrowing on the barrier surface has become more prevalent in recent years, suggesting that the restored barrier surface is beginning to function as a recovering ecosystem. Small-mammal burrowing on the top and sides of the barrier is most prevalent on the finergrained and disturbed soils while active ant mounds were observed on the northern and western slopes. 



\section{Contents}

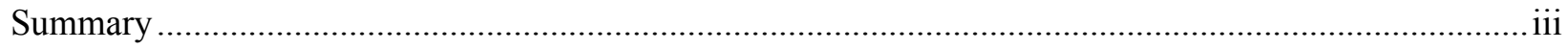

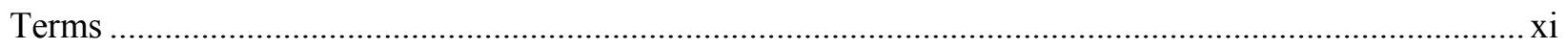

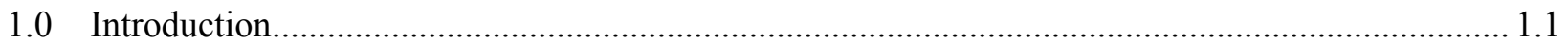

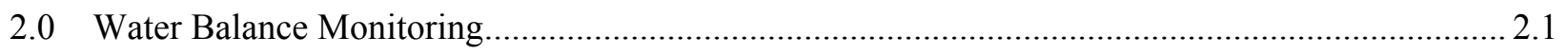

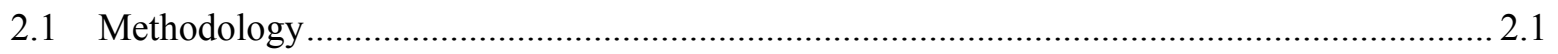

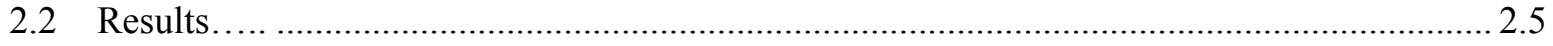

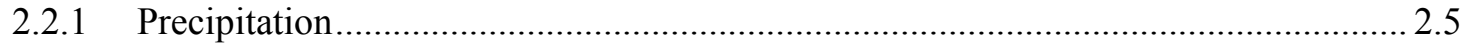

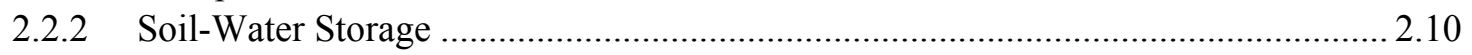

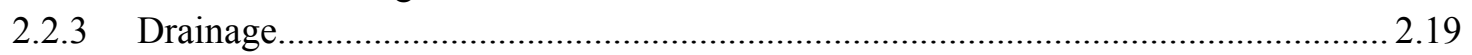

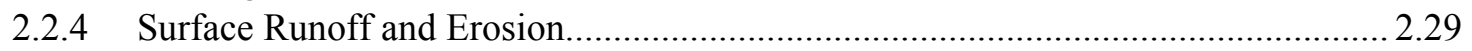

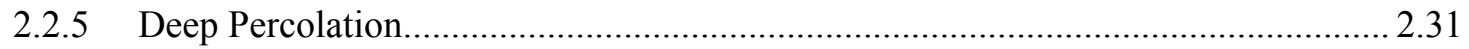

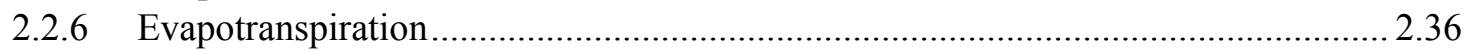

2.3 Recommendations for Fiscal Year 2005 ....................................................................... 2.37

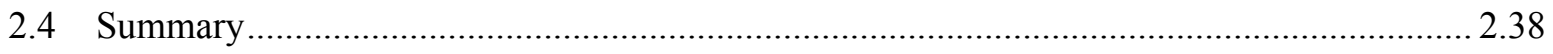

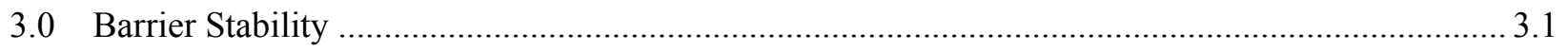

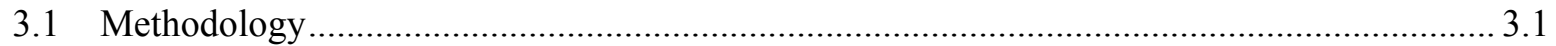

3.1.1 DEM Generation from Aerial Photogrammetry ................................................... 3.2

3.1.2 DEM Generation from Global Positioning System Surveys ..................................... 3.4

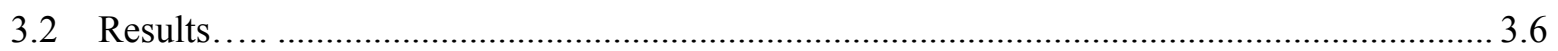

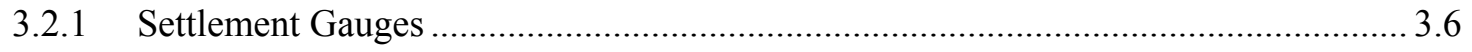

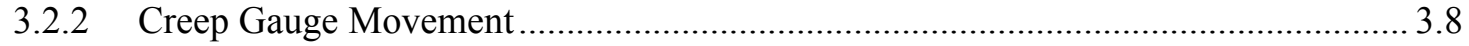

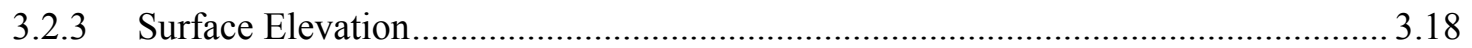

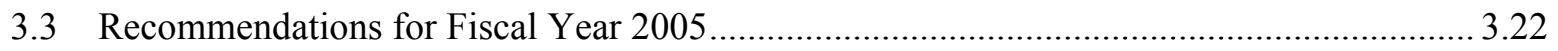

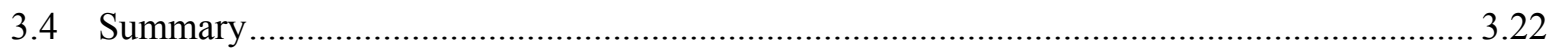

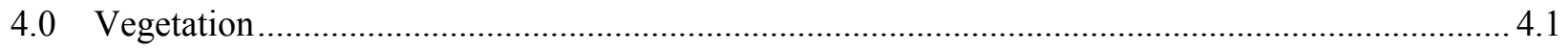

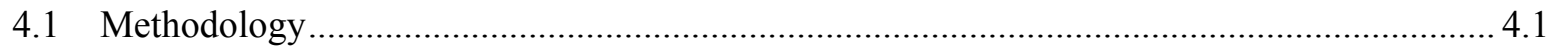

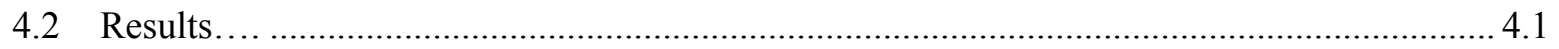

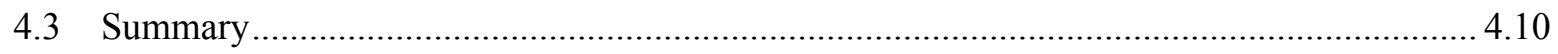

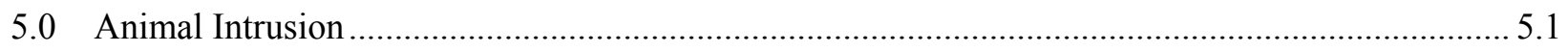

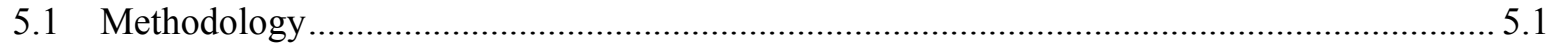

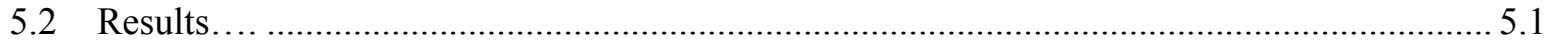

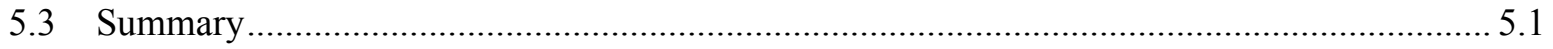


6.0 References......

Appendix A: Water Content, Water Balance Summary, and Elevational Measurements for the Prototype Hanford Barrier, 2004 ............................................................................................... A.1

Appendix B: Vegetation Survey Measurements Taken at the PROTOTYPE HANFORD BARRIER, 2004 B. 1 


\section{Figures}

2.1. Plan View of the Prototype Hanford Barrier Showing Monitoring Stations ................................2.3

2.2. Plan View of the Prototype Hanford Barrier Showing the Layout of the 12 Surface Soil

Plots (1W to $6 \mathrm{~W}$ and $1 \mathrm{E}$ to $6 \mathrm{E}$ ) and Horizontal Neutron Access Tubes (AA Above Asphalt;

BA Below Asphalt)

2.3. Characteristics of 200-East Area Rainfall Events based on 15-min Measurements During a Thunderstorm on May 20, 2004

2.4. Characteristics of 200-East Area Rainfall Events based on 15-min Measurements During a Thunderstorm on May 22, 2004.

2.5. Natural and Total Precipitation (Natural plus Irrigation) at the Prototype Hanford Barrier From October 1, 1994, Through September 30, 2004.

2.6. Snow Accumulation at the Prototype Barrier from WY 2004 Snowfall

2.7. Temporal Variation in Soil-Water Storage in Northwest Plot $6 \mathrm{~W}$ at the Prototype Hanford Barrier, October 1994 Through September 2004

2.8. Temporal Variation in Soil-Water Storage in Northwest Plot 6E at the Prototype Hanford Barrier, October 1994 Through September 2004

2.9. Temporal Variation in Soil-Water Storage in Northwest Plot $3 \mathrm{~W}$ at the Prototype Hanford Barrier, October 1994 Through September 2004

2.10. Temporal Variation in Soil-Water Storage in Northwest Plot 3E at the Prototype Hanford Barrier, October 1994 Through September 2004

2.11. Temporal Variation in Mean Soil-Water Storage on the North and South Plots at the Prototype Hanford Barrier, October 1994 Through September 2004

2.12. Temporal Variation in Mean Soil-Water Storage on the North Plots at the Prototype Hanford Barrier, March 51994 Through August 31 2004, Based on TDR Measurements

2.13. Temporal Variation in Mean Soil-Water Storage on the South Plots at the Prototype Hanford Barrier, March 51994 Through August 31 2004, Based on TDR Measurements

2.14. Temporal Variation in Soil-Water Content Measured by ECHO Probes on the Gravel Side Slope at the Prototype Hanford Barrier, November 27, 2002, Through August 31, 2004

2.15. Temporal Variation in Soil-Water Content Measured by ECHO Probes on the Gravel Side Slope at the Prototype Hanford Barrier During the Thunderstorms on May 20 and 22, 2004 ..... 2.19

2.16. Cumulative Amounts of Water Diverted by the Asphalt Pad (Drainage) from the SoilCovered Plots at the Prototype Hanford Barrier in September 1994 Through September 2004

2.17. Cumulative Amounts of Water Diverted by the Asphalt Pad (Drainage) from the SideSlope Plots at the Prototype Hanford Barrier in September 1994 Through September 2004 
2.18. Cumulative Amounts of Water Diverted by the Asphalt Pad (Drainage) from the SideSlope Plots at the Prototype Hanford Barrier After the Treatability Test, June 1999

Through September 2004 .

2.19. Cumulative Amounts of Water by Water Year Diverted by the Asphalt Pad (Drainage) From the Side-Slope Plots at the Prototype Hanford Barrier in September 1994 Through September 2004

2.20. Cumulative Amounts of Water by Water Year Diverted by the Asphalt Pad (Drainage) From the Side-Slope Plots at the Prototype Hanford Barrier in September 1994 Through September 2004 as a Percentage of Precipitation.

2.21. A Comparison of Cumulative Amount of Water Diverted by the Asphalt Pad (Drainage) Under the Gravel Side Slope as Measured by Pressure Transducers in the Siphons Vaults and a Water Fluxmeter for the Period May 1, 2004, through May 31, 2004.

2.22. A Comparison of Cumulative Amount of Water Diverted by the Asphalt Pad (Drainage) Under the Gravel Side Slope as Measured by Pressure Transducers in the Siphons Vaults and a Water Fluxmeter for the Period June 1, 2004, through June 30, 2004.

2.23. A Comparison of Cumulative Amount of Water Diverted by the Asphalt Pad (Drainage) Under the Gravel Side Slope Measured in the Siphons Vaults and Water Fluxmeters for the Period November 27, 2002, through September 17, 2004

2.24. Evidence of Erosion Near the Prototype Barrier Resulting from a Thunderstorm in May 2004.

2.25. North-Facing Photograph Taken on 6/16/04 from the BY Tank Farm During an Inspection by Kirk Christensen and Curt Wittreich (standing in channel)

2.26. Spatiotemporal Variations in Soil-Water Content at the Bottom of the Silt-Loam Layer of the Irrigated Treatment of the Barrier.

2.27. Spatiotemporal Variations in Soil-Water Content at the Bottom of the Silt-Loam Layer of the Nonirrigated Treatment of the Barrier.....

2.28. Spatial Variation in Soil-Water Content Under the Asphalt Layer (Uncurbed Section) on March 28, 1995, and April 30, 2003.

2.29. Comparison of Average Evapotranspiration Rate at the Prototype Hanford Barrier

3.1. Example of two Overlapping Images used to Extract Control Point of Generation of the Digital Elevation Model....

3.2. Locations of the Ground Control Points.

3.3. Outline of Sampling Area used for Calculation of Elevation ........................................................... 3.3

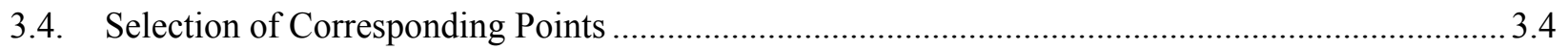

3.5. Real-Time Kinematic GPS Surveying System with a 5700 Receiver and Trimmark 3 Base

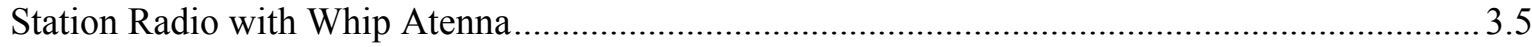

3.6. Real-Time Kinematic 5800 Rover Unit at the Prototype Barrier ............................................... 3.6 
3.7. Summary of Changes in Settlement Gauge Elevation Between November 1, 1994, and May 10, 2004

3.8. Net Creep Gauge Movement Between December 1994 and May 2004.

3.9. Net Creep Gauge Movement Between December 1994 and May 2004

3.10. Net Creep Gauge Movement Between December 1994 and May 2004

3.11. Net Creep Gauge Movement Between December 2001 and May 2004.

3.12. Creep Gauge Movement Between December 2001 and May 2004.

3.13. Creep Gauge Elevation Changes Between December 1994 and May 2004

3.14. Creep Gauge Elevation Changes Between December 1994 and May 2004

3.15. Creep Gauge Elevation Changes Between December 1994 and May 2004

3.16. Creep Gauge Elevation Changes Between February 2000 and May 2004 ...

3.17. Surface Elevations in Meters at the Prototype Hanford Barrier as Measured by Three Different Methods

3.18. Differences in Surface Elevation (meters) as Measured by Three Methods Measured by Three Different Methods

3.19. Surface Elevation (10× Vertical Exaggeration) at the Prototype Hanford Barrier as of May 10, 2004 Measured Using a Real-Time Kinematic Global Position System.

4.1. Temporal Variation in the Number of Annual and Perennial Species Including Total Species on the Prototype Hanford Barrier.

\section{Tables}

2.1. Expected Measurement Precision for Prototype Hanford Barrier Monitoring..............................2.6

2.2. Annual and Seasonal Natural Precipitation for the Hanford Site, 1994 Through 2004

2.3. Amounts of Water Diverted by the Asphalt Pad (Drainage) from the North Plots at the Prototype Hanford Barrier and the Relationship to Barrier Precipitation

2.4. Amounts of Water Diverted by the Asphalt Pad (Drainage) from the South Plots at the Prototype Hanford Barrier and the Relationship to Barrier Precipitation

3.1. Elevations and Elevation Changes of Settlement Gauges from December 1994 ….......................3.7

4.1. Shrub Measurement Summary Data of 2004 on the Prototype Hanford Barrier........................... 4.2

4.2. Median, Mode, and Mean Percent Cover Classes Ranges (2 pages) ........................................... 4.3

4.3. Plant Species Observed in 2004 on the Prototype Hanford Barrier Surface, Formerly Irrigated and Non-Irrigated Sections 
4.4. Plant Species Observed in 2004 on the North and West Side Slopes of the Prototype Hanford Barrier ..... 4.6

4.5. Plant Species Observed on the Prototype Hanford Barrier in Previous Years ${ }^{(a)}$ (3 pages). 


\section{Terms}

$\begin{array}{ll}\text { AP } & \text { Aerial Photogrammetry } \\ \text { CERCLA } & \text { Comprehensive Environmental Response, Compensation, and Liability Act of } 1980 \\ \text { DEM } & \text { digital elevation model } \\ \text { DOE-RL } & \text { U.S. Department of Energy Richland Operations } \\ \text { DP } & \text { deep percolation } \\ \text { ECHO } & \text { ECH }{ }_{2} \text { O, moisture sensor system (Decagon Devices, Inc.) } \\ \text { EDM } & \text { electronic distance measurement } \\ \text { EMI } & \text { electromagnetic induction } \\ \text { ET } & \text { evapotranspiration } \\ \text { FY } & \text { fiscal year } \\ \text { GPR } & \text { ground-penetrating radar } \\ \text { GPS } & \text { global positioning system } \\ \text { HMS } & \text { Hanford Meteorological Station } \\ \text { PNNL } & \text { Pacific Northwest National Laboratory } \\ \text { PSB } & \text { Prototype surface barrier } \\ \text { RTK } & \text { real time kinematic } \\ \text { TDR } & \text { time domain reflectometry } \\ \text { WY } & \text { water year }\end{array}$




\subsection{Introduction}

The prototype Hanford barrier, deployed over the 216-B-57 Crib, was constructed in 1994 to evaluate surface-barrier constructability, construction costs, and physical and hydrologic performance at the field scale. The barrier was routinely monitored between November 1994 and September 1998 as part of a Comprehensive Environmental Response, Compensation, and Liability Act of 1980 (CERCLA)

(42 USC 9601) treatability test of barrier performance for the 200-BP-1 Operable Unit. The results of the 4-year (fiscal years [FY] 1995 to 1998) treatability test are documented in 200-BP-1 Prototype Barrier Treatability Test Report (DOE-RL 1999). Since FY 1998, monitoring has focused on a more limited set of key water balance, stability, and biotic parameters with results summarized in annual letter reports (CCN 073428, “200-BP-1 Prototype Hanford Barrier Annual Monitoring Report for FY 1999”; CCN 083132, "200-BP-1 Prototype Hanford Barrier Annual Monitoring Report for Fiscal Year 2000"; CCN 100381, "200-BP-1 Prototype Hanford Barrier Annual Monitoring Report for FY 2001"; CP 14873, "200-BP-1 Prototype Hanford Barrier Annual Monitoring Report for FY 2002"; and CP 18187, "200-BP1 Prototype Hanford Barrier Annual Monitoring Report for FY 2003"). As in previous years, the FY 2004 barrier-performance monitoring activities were as follows:

- Water-balance monitoring, consisting of precipitation, soil moisture, and drainage measurements

- Barrier-stability monitoring, consisting of asphalt-layer-settlement, basalt-side-slope-stability, and surface-elevation measurements

- Vegetation survey

- Animal-intrusion survey.

This report summarizes the results of monitoring activities performed in FY 2004 and compares these results to those obtained in previous years. 


\subsection{Water Balance Monitoring}

In FY 2004, monitoring of selected water-balance components continued to allow evaluation of the barrier's hydrologic performance. A simplified water balance for the prototype barrier can be written as follows:

$$
P-D-D P-R-\Delta W-E T=0
$$

where

$$
\begin{aligned}
P & =\text { natural precipitation } \\
D & =\text { drainage out of the soil cover (diverted by the asphalt) } \\
D P & =\text { deep percolation (vertical drainage past the asphalt layer) } \\
R & =\text { surface runoff } \\
\Delta W & =\text { change in soil-water storage } \\
E T & =\text { evapotranspiration. }
\end{aligned}
$$

Evapotranspiration (ET) is the only component not measured; it is calculated by solving Equation 2.1:

$$
E T=P-(D+D P+R+\Delta W) .
$$

The change in storage, $\Delta \mathrm{W}$, is calculated as the difference in $\mathrm{W}$ measured at different times. Soil-water storage, $\mathrm{W}$, is calculated from measurements of soil-water content, $\theta$, by integrating $\theta$ over depth profiles. Thus, $\mathrm{W}$ between the surface and depth, $z$, is calculated as follows:

$$
W=\int_{0}^{L} \theta(z) d z \approx L_{1} \theta_{1}+\sum_{i=1}^{n-1} L_{i+1} \frac{\left(\theta_{i}-\theta_{i+1}\right)}{2}
$$

where

$L=$ total depth of characterization $(2 \mathrm{~m})$

$\theta_{1}=$ volumetric soil-water content at the first measurement points

$L_{1}=$ distance from surface to first measurement point

$n=$ number of measurement points

${ }_{i}=$ volumetric soil-water content at the $\mathrm{i}^{\text {th }}$ depth in the profile

$L_{i}=$ distance between successive measurement points.

The components selected for continued monitoring were precipitation, drainage (water diverted by the asphalt layer), deep percolation (leakage through the asphalt layer), and water storage. In addition to monitoring the water-balance components, horizontal distributions of soil-water content were measured at the capillary break (silt loam-sand filter interface) and beneath the asphalt layer. A pan lysimeter beneath the northeast corner of the asphalt layer also was monitored routinely for leakage, which, in this case, is analogous to deep drainage and would represent potential recharge through the cover.

\subsection{Methodology}

To monitor the water-balance components in the top 2-m silt-loam layer of the barrier, the surface is fitted with 14 water-balance monitoring stations (S1 through S14; Figure 2.1). The stations are arranged with 
three in each of the four silt-loam-covered plots $(3 \mathrm{~W}, 3 \mathrm{E}, 6 \mathrm{~W}$, and $6 \mathrm{E})$ and one in each of the two gravelcovered plots (1W and 4W).

The temporal and spatial distribution of precipitation is particularly important to understanding barrier performance and is monitored using precipitation meters installed at each monitoring station. The meters are described in DOE-RL (1999). Data currently are being collected on an hourly basis and are supplemented with precipitation data from the Hanford Meteorological Station. This report includes only temporal averages of precipitation. More detailed spatial and temporal information is stored in the project database and can be made available in an electronic format.

For monitoring the drainage component, D, in Equation 2.2, the barrier is equipped with an automated drainage-monitoring system. This system is composed of 12 concrete vaults located to the north and downgradient from the asphalt layer to allow the movement of water by gravity (DOE-RL 1999). A series of curbs divides the surface of the asphalt into 12 water-collection zones, the boundaries of which align vertically with the 12 surface plots shown in Figure 2.2. Water that moves through the surface layers of the barrier and onto the curbed asphalt is piped to the drainage vaults. Drainage water flows into each vault via a datalogger-controlled tipping-bucket rain gauge, which allows monitoring of low flows. Hydrostatic pressure, a function of water height, is recorded using pressure transducers to monitor intermediate and high flow rates. At present, measurements are made hourly. Detailed instructions on the measuring procedure are contained in Procedures for Routine Maintenance and Calibration of Dosing Siphons at the Prototype Surface Barrier (PNL 1995). Monitoring of deep percolation (DP) is facilitated by a $6.5-\mathrm{m}$ by $6.5-\mathrm{m}$ pan lysimeter installed under the northeast section (centered on plot 4E) of the asphalt layer (DOE-RL 1999). The lysimeter, which resembles an inverted pyramid, is sealed around the perimeter to the underside of the asphalt layer. A pair of 1.65-mm-diameter stainless steel tubes is used for venting and siphoning water from the bottom of the lysimeter. Any water siphoned from the lysimeter tube is routed to a tipping bucket and monitored by a datalogger. The lysimeter is monitored daily.

In FY 2002, the original monitoring network was expanded with the addition two water fluxmeters to monitor unsaturated water flux density through the gravel side slope. Data from the fluxmeters allow direct comparison of recharge rate, as a function of slope position, on the gravel slope. These measurements are critical to the estimation of recharge at the barrier's edge from the protective slopes.

Surface runoff is monitored through the use of a 6.1-m-wide by 15.2-m-long erosion flume located in the northwest section of the barrier (Figure 2.1). The erosion flume is designed to capture and convey runoff to an automated water and sediment sampler. Water storage is monitored using measurements taken by a neutron hydroprobe (Procedure for Measuring Soil Moisture Using the Neutron Probe in the Neutron Probe Access Tube Vertical and Horizontal Array [PNNL 1995]) and by time domain reflectometry (TDR) (Measuring Soil Water Content With the Moisture Point Time Domain Reflectometry System [PNNL 1999]). As part of the monitoring network expansion in FY 2002, two sets of $\mathrm{ECH}_{2} \mathrm{O}$ Model EC$20^{\text {(a) }}$ moisture sensors (ECHO probe) were installed at the barrier to evaluate their capability to monitor

(a) $\mathrm{ECH}_{2} \mathrm{O}$ is a registered trademark of Decagon Devices, Inc., Pullman, Washington. 


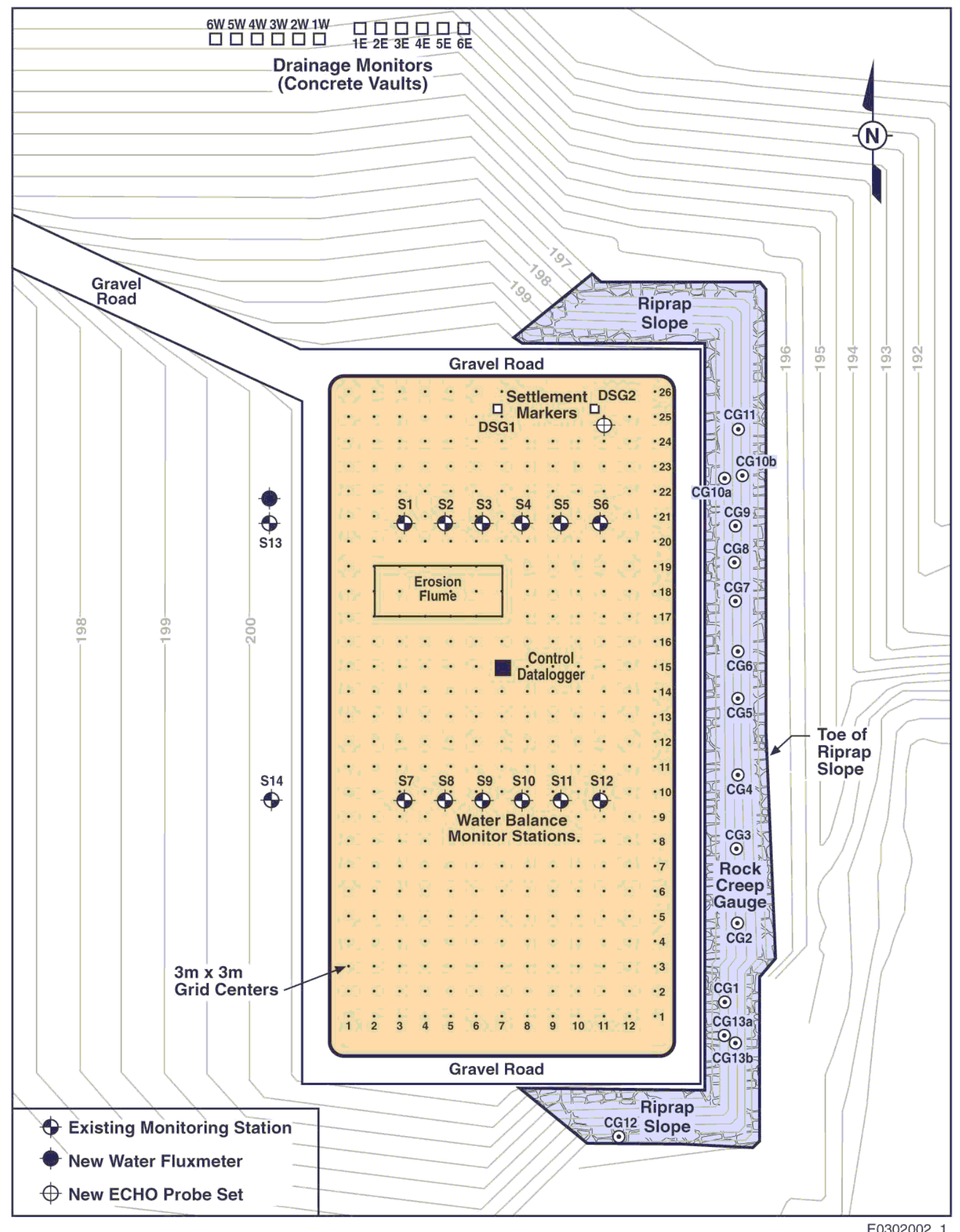

Figure 2.1. Plan View of the Prototype Hanford Barrier Showing Monitoring Stations 


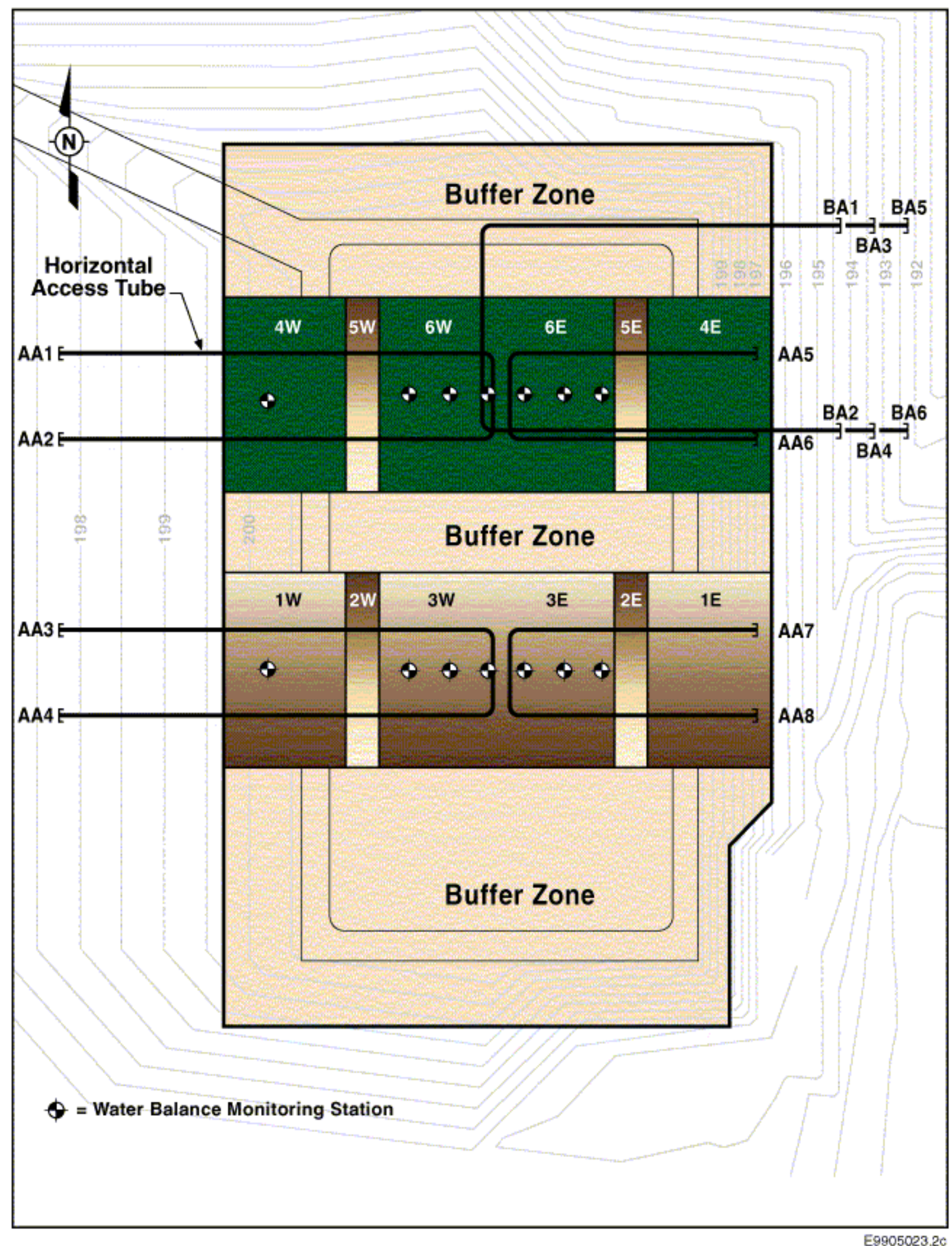

Figure 2.2. Plan View of the Prototype Hanford Barrier Showing the Layout of the 12 Surface Soil Plots (1W to 6W and 1E to 6E) and Horizontal Neutron Access Tubes (AA Above Asphalt; BA Below Asphalt) 
water storage (Fluor Hanford 2003). The ECHO probe is a relatively low-cost sensor that uses dielectric measurements to estimate soil volumetric water content. The $\mathrm{ECHO}_{2} \mathrm{O}$ probes and their installation are described in CP-14873. Briefly, a set of five probes was installed in the silt-loam cover about $3 \mathrm{~m}$ north of station S6 (Figure 2.1). A second set was installed on the gravel slope. The side-slope installation is downslope of monitoring station S13, just below and north of the end of the horizontal neutron access

tube AA1 (Figure 2.2). For the silt loam installation, five ECHO probes are installed vertically in the 2-m silt-loam layer, starting at the bottom and moving toward the surface. The first probe was installed with the distal end at the $1.5-\mathrm{m}(5-\mathrm{ft})$, depth and the remaining probes were installed $30 \mathrm{~cm}$ apart. On the gravel slope, three probes were installed at $36-\mathrm{cm}$ to $60-\mathrm{cm}$ and $5-\mathrm{cm}$ to $30.5-\mathrm{cm}$ depths.

Although not specifically used to assess water storage, neutron logging using horizontal access tubes is used to monitor several zones of the barrier for changes in the soil moisture content. At the west side of the prototype surface barrier, two pairs of U-shaped horizontal access tubes were installed at $1.95 \mathrm{~m}$ below the surface, near the capillary break (silt loam-sand filter interface) (AA1, AA2, AA3, AA4; Figure 2.2). A similar set of tubes (AA5, AA6, AA7, AA8) was installed at $1.95 \mathrm{~m}$ on the east side. Three additional sets of tubes were installed under the northeast section of the barrier below the asphalt layer. Tubes BA1 and BA2 were installed at a depth of $1 \mathrm{~m}$ below the asphalt, tubes BA3 and BA4 at 2 $\mathrm{m}$, and tubes BA5 and BA6 at $3 \mathrm{~m}$ below the asphalt layer. The northeast corner of the asphalt layer (under the north buffer zone) was left uncurbed to assess the amount of underflow at the edge of the asphalt.

Table 2.1 summarizes the measurements taken at the barrier, and the measurement precision of each instrument. In FY 2004, surface elevations were measured for the first time using two additional techniques, 1) aerial photogrammetry and 2) the differential global positioning system (GPS). The measurement precision of these techniques is also summarized in Table 2.1.

\subsection{Results}

\subsubsection{Precipitation}

Table 2.2 summarizes the precipitation at the Hanford Site on an annual and a seasonal basis for the duration of monitoring at the prototype barrier. These data are derived from measurements taken at the Hanford Meteorological Station (HMS) and are discussed in greater detail in site climatological data summaries (Hanford Site Climatological Data Summary 2003 with Historical Data [PNNL 2004]). During this period, the mean annual precipitation onsite has exceeded the normal precipitation by over 10 percent. The range, however, is much larger, with annual precipitation varying from a low of $95.25 \mathrm{~mm}$ in 1999 to a high of $312.67 \mathrm{~mm}$ in 1995. Precipitation in FY 2004 (October 1, 2003, through September 30, 2004) totaled $218.95 \mathrm{~mm}$.

Although the difference between the totals for FY 2004 and FY 2003 (224.028 mm) is less than 3 percent, there is significant variability in the seasonal distribution for this year and previous years. The highest winter precipitation for the monitoring period was $138.4 \mathrm{~mm}$ in FY 1997, almost a factor of four more than the lowest of $35 \mathrm{~mm}$ recorded in the winter of FY 2001. Of the FY 2004 total, $126.5 \mathrm{~mm}$ occurred during the winter (December 2003, January 2004, and February 2004). Winter precipitation for the last two years is almost twice the normal average winter precipitation for the Hanford Site and is only slightly less than that observed in FY 1997. Last year's winter is the second consecutive year of elevated winter precipitation since FY 1997. Since 1997, winter precipitation has shown a steady decline, reaching a low 
Table 2.1. Expected Measurement Precision for Prototype Hanford Barrier Monitoring

\begin{tabular}{|c|c|c|c|}
\hline Variable & Measurement Method & Resolution & Expected Precision \\
\hline Precipitation, $\mathrm{P}(\mathrm{mm})$ & Load cells & $\pm 0.2 \mathrm{~mm}$ & $\pm 0.2 \mathrm{~mm}$ \\
\hline Water storage, $\mathrm{W}(\mathrm{mm})$ & $\begin{array}{l}W=\int_{0}^{L} \theta(z) d z, \\
\theta \text { measured from surface to } \\
\text { depth L by neutron probe } \\
\text { and time domain } \\
\text { reflectometry (TDR) }\end{array}$ & $\begin{array}{l}\text { Neutron probe: } \\
\pm 0.005 \mathrm{~m}^{3} \mathrm{~m}^{-3} \\
\text { TDR: } \pm 0.003 \mathrm{~m}^{3} \mathrm{~m}^{-3} \\
\text { ECHO }^{\mathrm{a}}: \pm 0.001 \mathrm{~m}^{3} \mathrm{~m}^{-3}\end{array}$ & $\begin{array}{l}\text { Neutron probe: } \pm 10.0 \mathrm{~mm} \\
\text { over depth L, subject to } \\
\text { confidence interval of } \\
\text { calibration curve } \\
\text { TDR: } \pm 6.0 \mathrm{~mm} \text { over depth L } \\
\text { ECHO: } \pm 2.0 \mathrm{~mm} \text { over L }\end{array}$ \\
\hline Surface runoff, R (mm) & Isco flowmeter ${ }^{b}$ & $\pm 0.25 \mathrm{~mm}$ & $\pm 0.25 \mathrm{~mm}$ \\
\hline \multirow{3}{*}{ Drainage, D (mm) } & Tipping-bucket gauge & $\pm 0.025 \mathrm{~mm}$ & $\begin{array}{l}\text { Main plot: } 3.52 \times 10^{-5} \mathrm{~mm} \\
\text { Trans plot: } 7.04 \times 10^{-5} \mathrm{~mm}\end{array}$ \\
\hline & Pressure transducer & $\pm 0.025 \mathrm{~mm}$ & $\begin{array}{l} \pm 0.26 \mathrm{~mm} \mathrm{yr}^{-1} \text {; controlled by } \\
\text { seepage through walls of } \\
\text { vault }\end{array}$ \\
\hline & Fluxmeter & $\pm 0.15 \mathrm{~mm}$ & $0.15 \mathrm{~mm} \mathrm{yr}^{-1}$ \\
\hline $\begin{array}{l}\text { Evapotranspiration, ET } \\
(\mathrm{mm})\end{array}$ & $\begin{array}{l}\text { By difference; } \\
\mathrm{ET}=\mathrm{P}-(\mathrm{D}+\mathrm{DP}+\mathrm{R}+\Delta \mathrm{W})\end{array}$ & $\begin{array}{l}\text { Set by least precise } \\
\text { component, } \Delta \mathrm{W}\end{array}$ & $\pm 10 \mathrm{~mm}$ \\
\hline \multirow{3}{*}{ Elevation, distance (m) } & $\begin{array}{l}\text { Electronic distance } \\
\text { measurement system }\end{array}$ & $5 \mathrm{~mm}+5 \mathrm{ppm}$ & $5 \mathrm{~mm}+5\left(\right.$ distance $\left./ 10^{6}\right)$ \\
\hline & Digital Photogrammetry & $\begin{array}{l}\text { Horizontal: } 3 \mathrm{~mm}+ \\
0.5 \mathrm{ppm}(\times \text { baseline } \\
\text { length }) \\
\text { Vertical: } 5 \mathrm{~mm}+ \\
0.5 \mathrm{ppm}(\times \text { baseline } \\
\text { length })\end{array}$ & $\begin{array}{l}\text { Horizontal: } 3 \mathrm{~mm}+0.5 \\
\left(\text { distance } / 10^{6}\right) \\
\text { Vertical: } 5 \mathrm{~mm}+0.5 \\
\left(\text { distance } / 10^{6}\right)\end{array}$ \\
\hline & Global Positioning System & $\begin{array}{l}\text { Horizontal: } 5 \mathrm{~mm}+ \\
0.5 \mathrm{ppm}(\times \text { baseline } \\
\text { length) } \\
\text { Vertical: } 5 \mathrm{~mm}+ \\
2.0 \mathrm{ppm}(\times \text { baseline } \\
\text { length })\end{array}$ & $\begin{array}{l}\text { Horizontal: } \\
5 \mathrm{~mm}+0.5\left(\text { distance } / 10^{6}\right) \\
\text { Vertical: } \\
5 \mathrm{~mm}+2.0\left(\text { distance } / 10^{6}\right)\end{array}$ \\
\hline
\end{tabular}


Table 2.2. Annual and Seasonal Natural Precipitation for the Hanford Site, 1994 Through 2004

\begin{tabular}{|c|c|c|c|c|c|}
\hline \multirow[b]{2}{*}{ Water Year $^{(a)}$ (WY) } & \multirow[b]{2}{*}{ Annual $^{(b)}$} & \multicolumn{4}{|c|}{ Precipitation (mm) } \\
\hline & & $\begin{array}{c}\text { Winter } \\
\text { (Dec-Feb) }^{(\mathrm{c})}\end{array}$ & $\begin{array}{c}\text { Spring } \\
\text { (Mar-May) }\end{array}$ & $\begin{array}{c}\text { Summer } \\
\text { (Jun-Aug) }\end{array}$ & $\begin{array}{c}\text { Autumn } \\
\text { (Sep-Nov) }\end{array}$ \\
\hline 1995 & 312.67 & 106.43 & 83.31 & 29.97 & 68.58 \\
\hline 1996 & 309.63 & 125.98 & 47.75 & 5.33 & 95.76 \\
\hline 1997 & 162.31 & 138.43 & 34.54 & 18.03 & 57.15 \\
\hline 1998 & 163.83 & 68.58 & 27.69 & 21.84 & 42.42 \\
\hline 1999 & 95.25 & 51.56 & 10.16 & 24.13 & 18.80 \\
\hline 2000 & 205.23 & 57.91 & 57.91 & 18.03 & 56.13 \\
\hline 2001 & 169.16 & 35.05 & 42.67 & 35.56 & 55.12 \\
\hline 2002 & 137.41 & 48.01 & 16.26 & 20.83 & 12.70 \\
\hline 2003 & 206.76 & 128.27 & 65.28 & 11.68 & 11.68 \\
\hline 2004 & 163.07 & 126.49 & 37.34 & 24.89 & na \\
\hline Normal $^{(\mathrm{d})}$ & 177.29 & 65.56 & 40.13 & 24.13 & 45.72 \\
\hline Barrier average $^{(\mathrm{e})}$ & 195.81 & 84.47 & 42.84 & 20.60 & 46.48 \\
\hline Standard deviation & 73.48 & 40.08 & 23.63 & 9.02 & 28.14 \\
\hline \multicolumn{6}{|c|}{$\begin{array}{l}\text { (a) The water year (WY) corresponds to the Federal fiscal year and runs from October } 1 \text { of a given year } \\
\text { through September } 30 \text { of the following year. } \\
\text { (b) Annual precipitation is total precipitation for the stated calendar year. } \\
\text { (c) Winter precipitation for a given WY includes precipitation for December of the previous calendar } \\
\text { year plus precipitation for January and February of the current year. } \\
\text { (d) Normal is the } 30 \text {-year average based on the period from } 1971 \text { through } 2000 \text {. } \\
\text { (e) Barrier average is the average over the period of monitoring, October } 1994 \text { through September } 2004 .\end{array}$} \\
\hline
\end{tabular}

of $35 \mathrm{~mm}$ in 2001 (Table 2.2). Given that most of the precipitation at the Hanford Site typically occurs in the winter, total precipitation showed a similar trend. FY 2004 also saw a shift in the seasonal distribution from the previous year with an almost 60-percent decline in spring precipitation, a 213percent increase in summer precipitation, and almost no change in winter precipitation.

Site data, in general, and in particular data from prototype, show that there can be significant spatial differences in precipitation. These differences are often associated with localized thunderstorms and could impact on barrier performance either through changes in the overall water balance or changes in specific components of the water balance. In addition, high intensity, localized storms could be an important factor in designing surface covers. In FY 2004, there were at least three localized storm events that are of particular interest. The first two occurred in May 2004, a particularly active month in which the Hanford Site received an average of $22.6 \mathrm{~mm}$, or $162 \%$ of normal. Five thunderstorms were recorded, compared to a normal of two and a record of seven in 1956. On May 20, a thunderstorm started around 16:30 and was localized to the 200 East area. This storm produced $18.03 \mathrm{~mm}$ with a maximum intensity of $47.75 \mathrm{~mm} \mathrm{hr}^{-1}$ (Figure 2.3). 


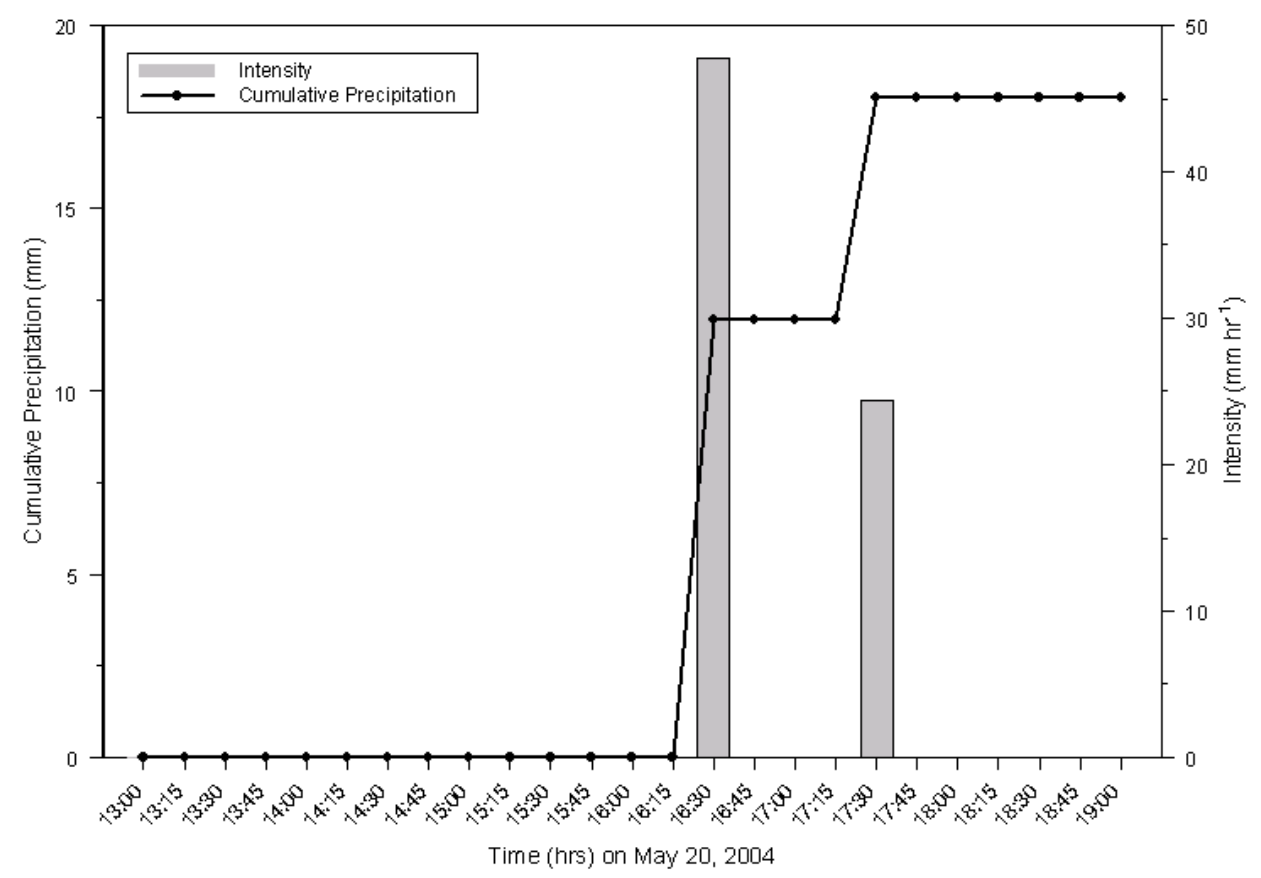

Figure 2.3. Characteristics of 200-East Area Rainfall Events based on 15-min Measurements During a Thunderstorm on May 20, 2004

Another storm on May 22 produced $13.21 \mathrm{~mm}$ with a maximum intensity of $36.58 \mathrm{~mm} \mathrm{hr}^{-1}$ (Figure 2.4). There were additional precipitation events on June 7 and 8, 2004, that produced significant amounts of rain $(6.10 \mathrm{~mm}$ on June $6 ; 12.19 \mathrm{~mm}$ on June 8$)$, but the intensities were much lower with values of $8.13 \mathrm{~mm} \mathrm{hr}^{-1}$ and $5.08 \mathrm{~mm} \mathrm{hr}^{-1}$, respectively. The storm of higher intensity is of particular interest because of the potential to be erosive. This storm is discussed further in Section 2.2.4.

In spite of the high-intensity events and the obvious changes in the seasonal distribution, no adverse effects were observed on the prototype barrier. The cumulative amount of water received from October 1 , 1994, through September 30, 2004, was $2559.58 \mathrm{~mm}$ on the northern half of the barrier, which is the formerly irrigated section. During the same period, $1886.71 \mathrm{~mm}$ fell on the barrier's southern half (Figure 2.5). Last year's winter precipitation resulted in significant amounts of snow accumulation on the barrier surface and side slopes (Figure 2.6). Predicting the long-term performance of surface covers at Hanford should therefore include the effects of snow accumulation and subzero temperatures on the water-balance components and the migration of water.

The analysis of seasonal variations in precipitation is particularly important in evaluating cover performance and designing future covers to be used at the Hanford Site. Vegetated capillary barriers are commonly designed to store all of the expected winter precipitation until it can be recycled by plants during the spring and summer months. Even with the prototype Hanford barrier's relatively short history, the short-term variation in precipitation is quite clear. This suggests a need for greater consideration of the short-term variation in precipitation as a design variable rather than the normal or long-term average precipitation values. The prototype Hanford barrier is designed with a 2-m silt-loam layer capable of storing approximately $600 \mathrm{~mm}$ of water, which is more than three times the long-term average precipitation $\left(160 \mathrm{~mm} \mathrm{yr}^{-1}\right)$ for the site. This capacity has never been exceeded, not even during the treatability test when the prototype was irrigated. 


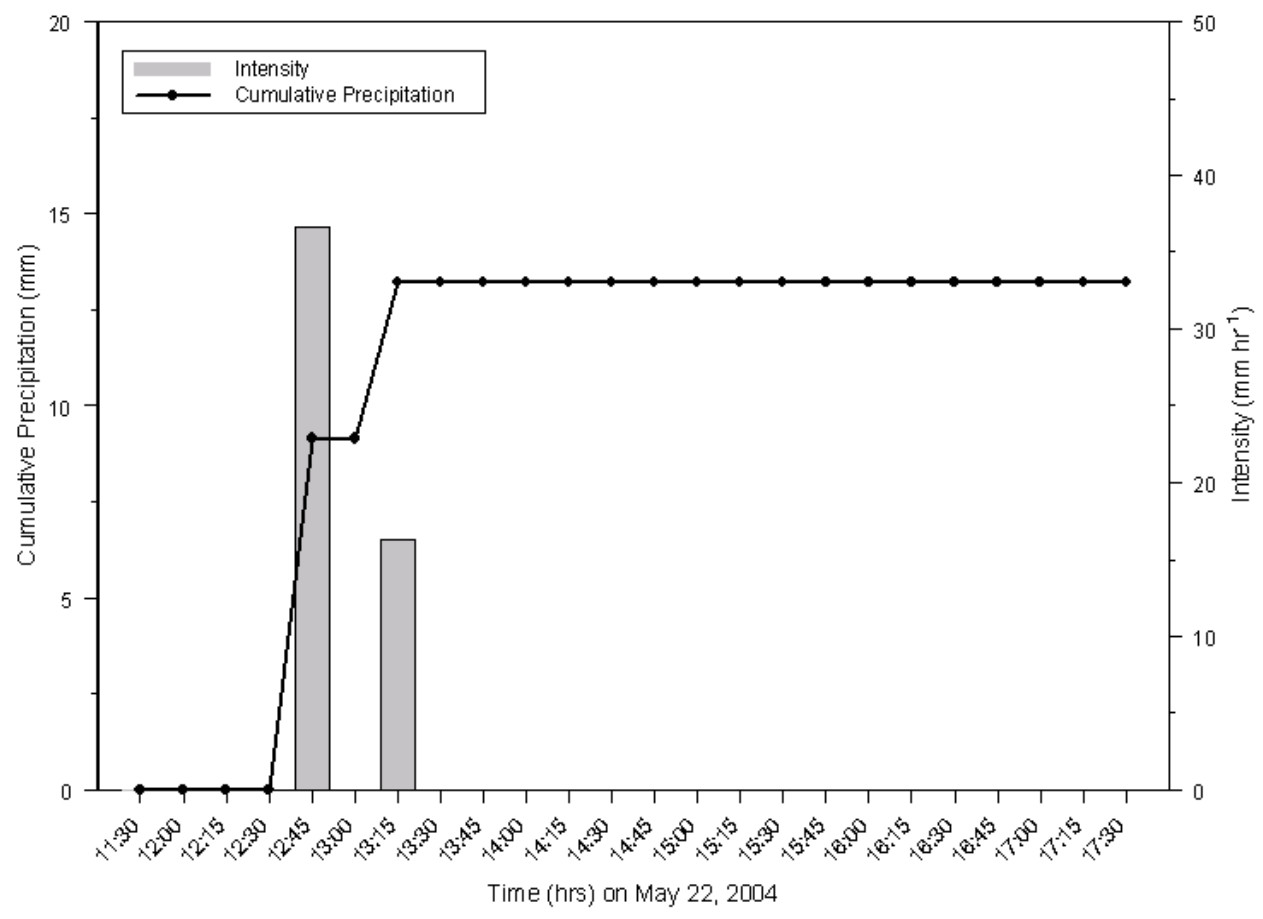

Figure 2.4. Characteristics of 200-East Area Rainfall Events based on 15-min Measurements During a Thunderstorm on May 22, 2004

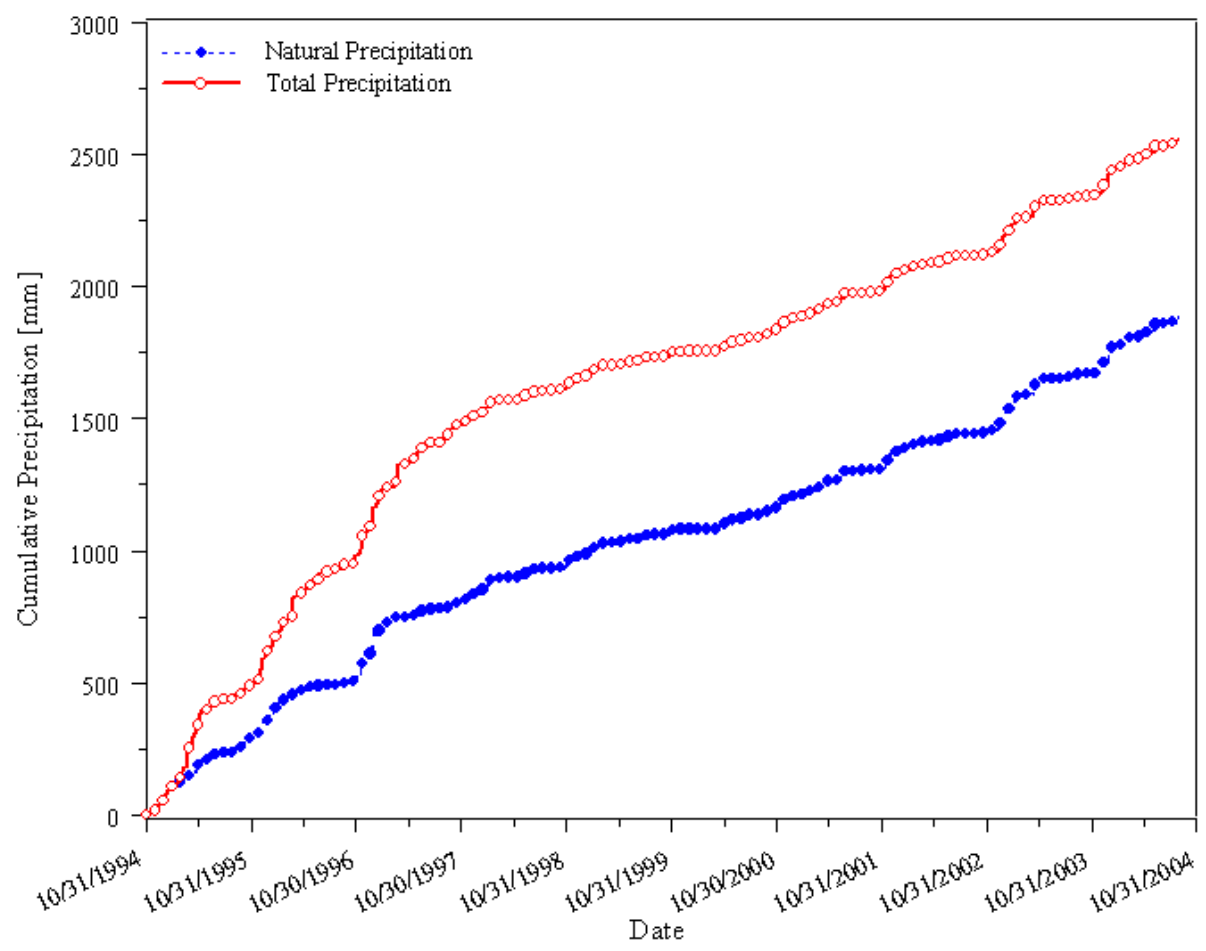

Figure 2.5. Natural and Total Precipitation (Natural plus Irrigation) at the Prototype Hanford Barrier From October 1, 1994, Through September 30, 2004 

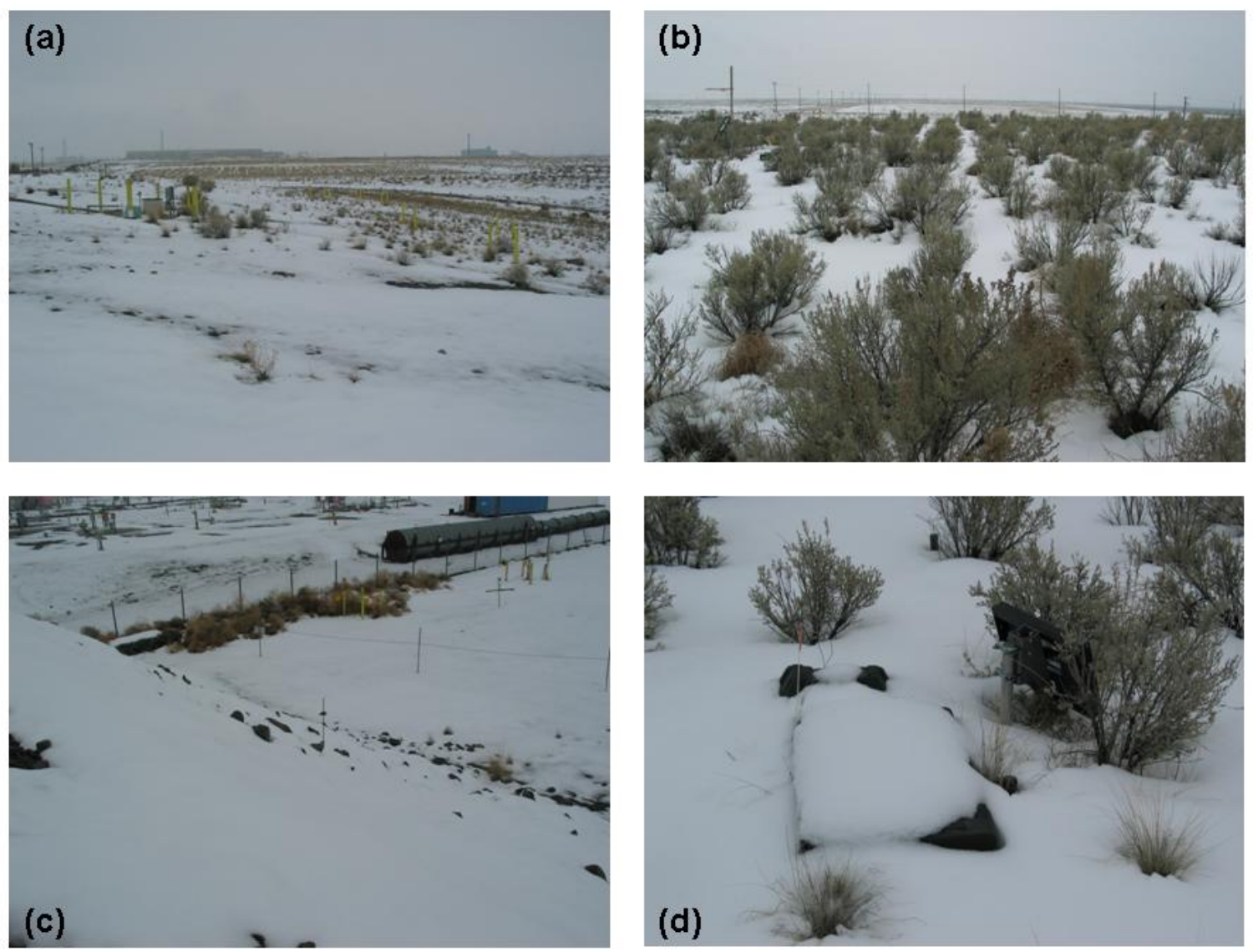

Figure 2.6. Snow Accumulation at the Prototype Barrier from WY 2004 Snowfall: (a) looking southwest on the gravel side slope, (b) looking northeast on the silt-loam surface, (c) looking southwest on the riprap side slope, and (d) accumulation on instrument boxes

\subsubsection{Soil-Water Storage}

As in previous years, water storage, $\mathrm{W}$, was calculated from water contents measured with a neutron probe and TDR. The neutron-probe method continues on a quarterly basis as a means of verification of the TDR-based water content measurements, which were initiated in FY 2000. A set of ECHO probes was installed in 2002 to evaluate their performance in measuring storage. Measured soil-water contents were used to calculate soil-water storage as a function of time, W(t), using Equation 2.3.

\subsubsection{Neutron-Probe Measurements}

Figure 2.7 through Figure 2.10 show distributions of W(t) on the silt-loam plots from September 30, 1994, through September 4, 2004, derived from neutron-probe measurements. Figure 2.7 and Figure 2.8 summarize measurements made on the northern half of the barrier, which was irrigated from 1995 through 1997 as part of the treatability test. Figure 2.9 and Figure 2.10 summarize measurements made on the southern half of the barrier, which was consistently maintained under ambient precipitation conditions. No storage data were collected in FY 1999, hence the break in the record. These data show a 
well-defined annual cycle in $\mathrm{W}(\mathrm{t})$ for the duration of monitoring with a much larger range during the 3 years of the treatability test. Although plants in both precipitation treatments were able to recycle most of the water intercepted by the barrier, the data show a treatment-dependent variation in $\mathrm{W}(\mathrm{t})$ at the end of each summer period. On the south side, which never received irrigation, plants removed water to essentially the same minimum $\mathrm{W}(\mathrm{t})$. The lower limit has shown little change over the monitoring period of 1994 through 2004.

On the north side, which was irrigated for 3 years, the picture is dramatically different. While the plants were able to recycle most of the applied water, the lower level of W(t) shows a clear spatial and temporal dependence. Through 1998 and into 1999, following the resumption of monitoring, the lower level of W continued to increase. This suggests a reduction in the efficiency of the plants on the northern half of the barrier to recycle water. This effect appears to be most dramatic in the northeastern corner where S5 and S6 appear to retain more water throughout the year.

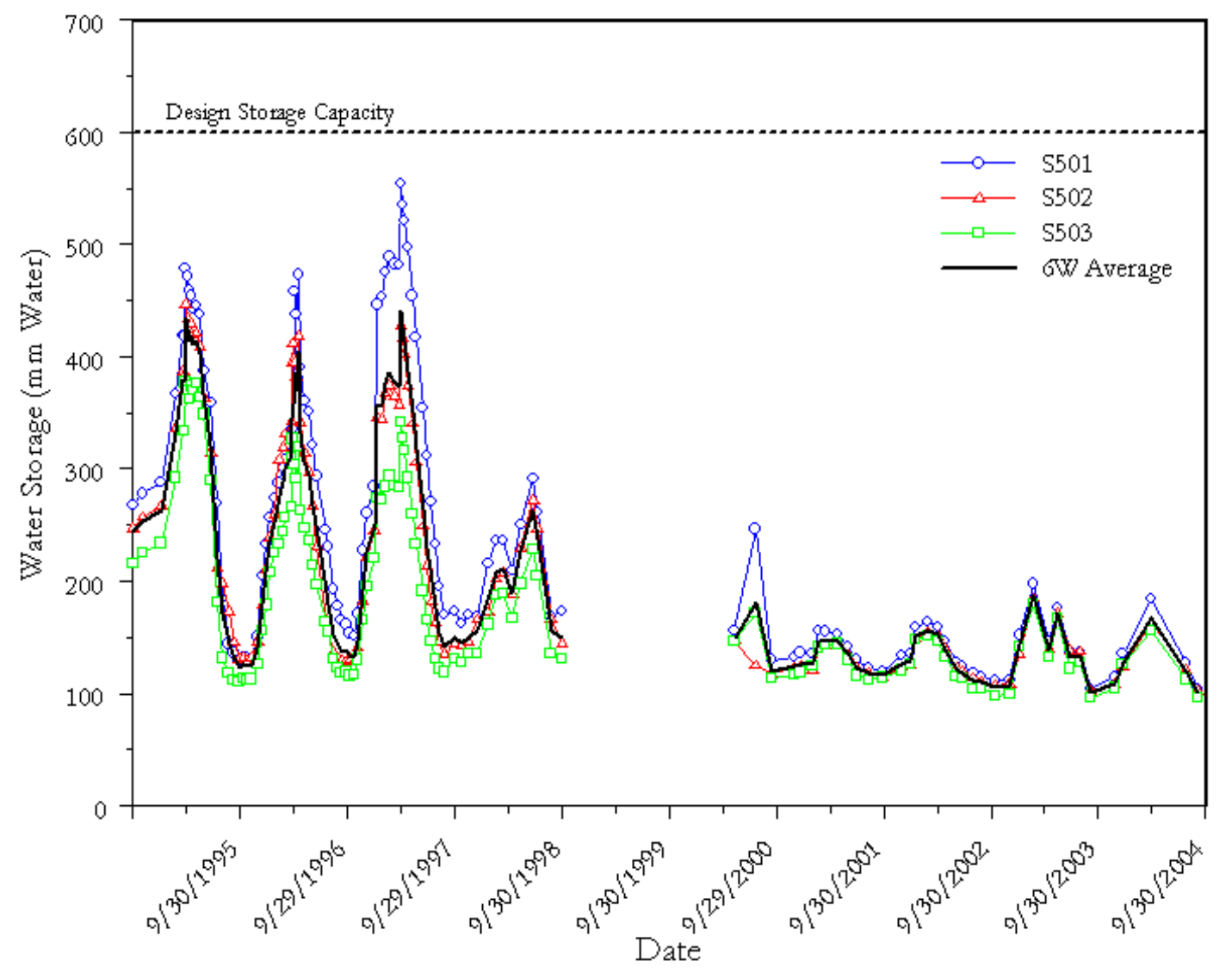

Figure 2.7. Temporal Variation in Soil-Water Storage in Northwest Plot $6 \mathrm{~W}$ at the Prototype Hanford Barrier, October 1994 Through September 2004 (design water storage capacity is $600 \mathrm{~mm}$ ) 


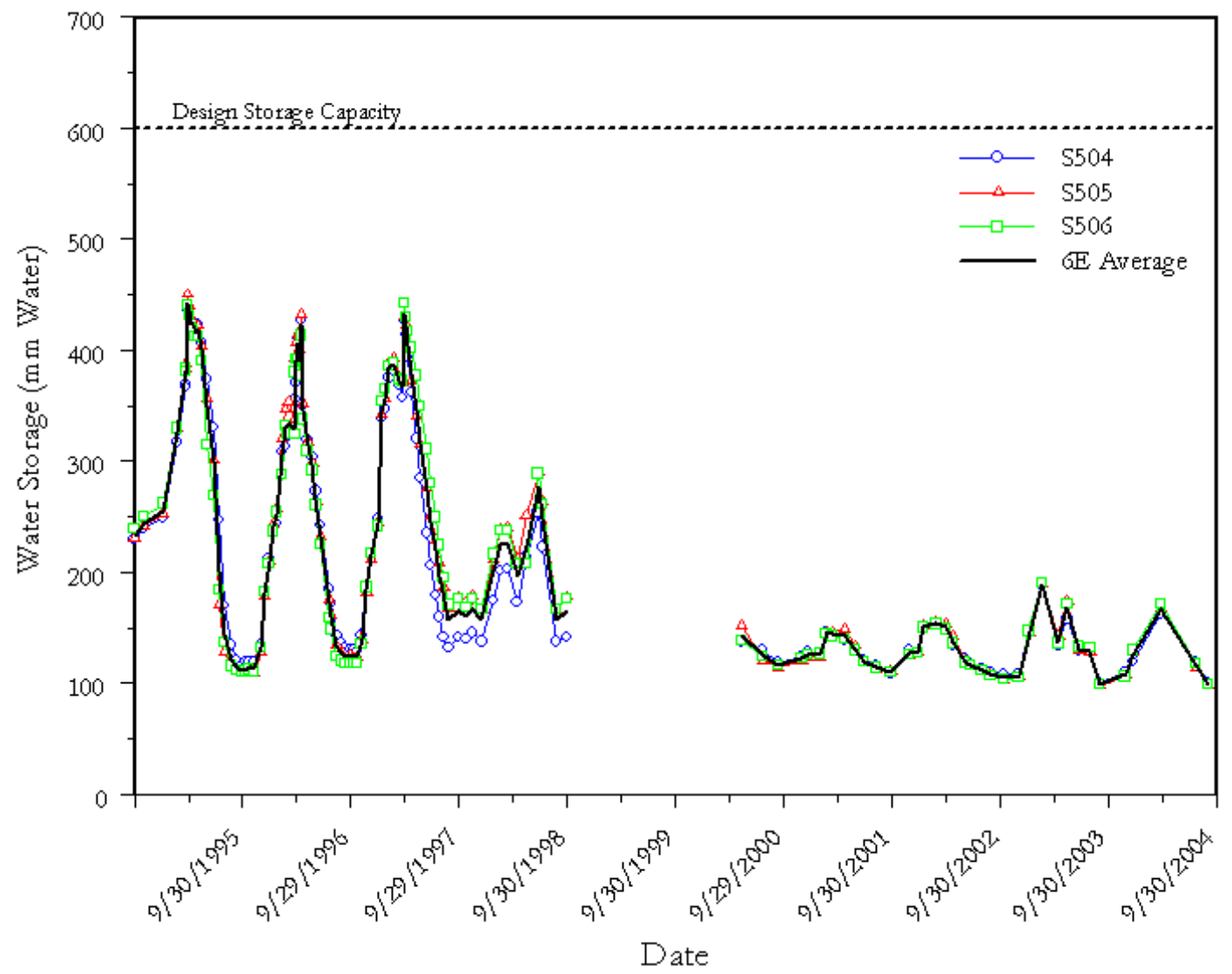

Figure 2.8. Temporal Variation in Soil-Water Storage in Northwest Plot 6E at the Prototype Hanford Barrier, October 1994 Through September 2004 (design water storage capacity is $600 \mathrm{~mm}$ )

This observation may be related to the distribution of plants on the cover. The northeast corner, particularly near water-balance monitoring stations S5 and S6, carried a predominance of grasses. Because grasses have a shallower root system and a different growth cycle than the shrubs on the barrier, they are less effective at removing water from deep in the profile, particularly later in the year after the wetting front has migrated beyond the top $0.5-\mathrm{m}$ depth. This reduced ability to remove water in areas dominated by grasses, such as the $6 \mathrm{E}$ plot, would contribute to a higher $\mathrm{W}(\mathrm{t})$ at the end of the summer. Nevertheless, the system had shown a dramatic recovery by mid 2000. By this time, differences in the lower limit of $\mathrm{W}(\mathrm{t})$ had essentially disappeared with the values returning to values similar to those observed on the south side of the barrier. These observations emphasize the importance of vegetation to the function of capillary barriers, as well as the resilience of the plant species in their ability to recover from short-term stresses. 


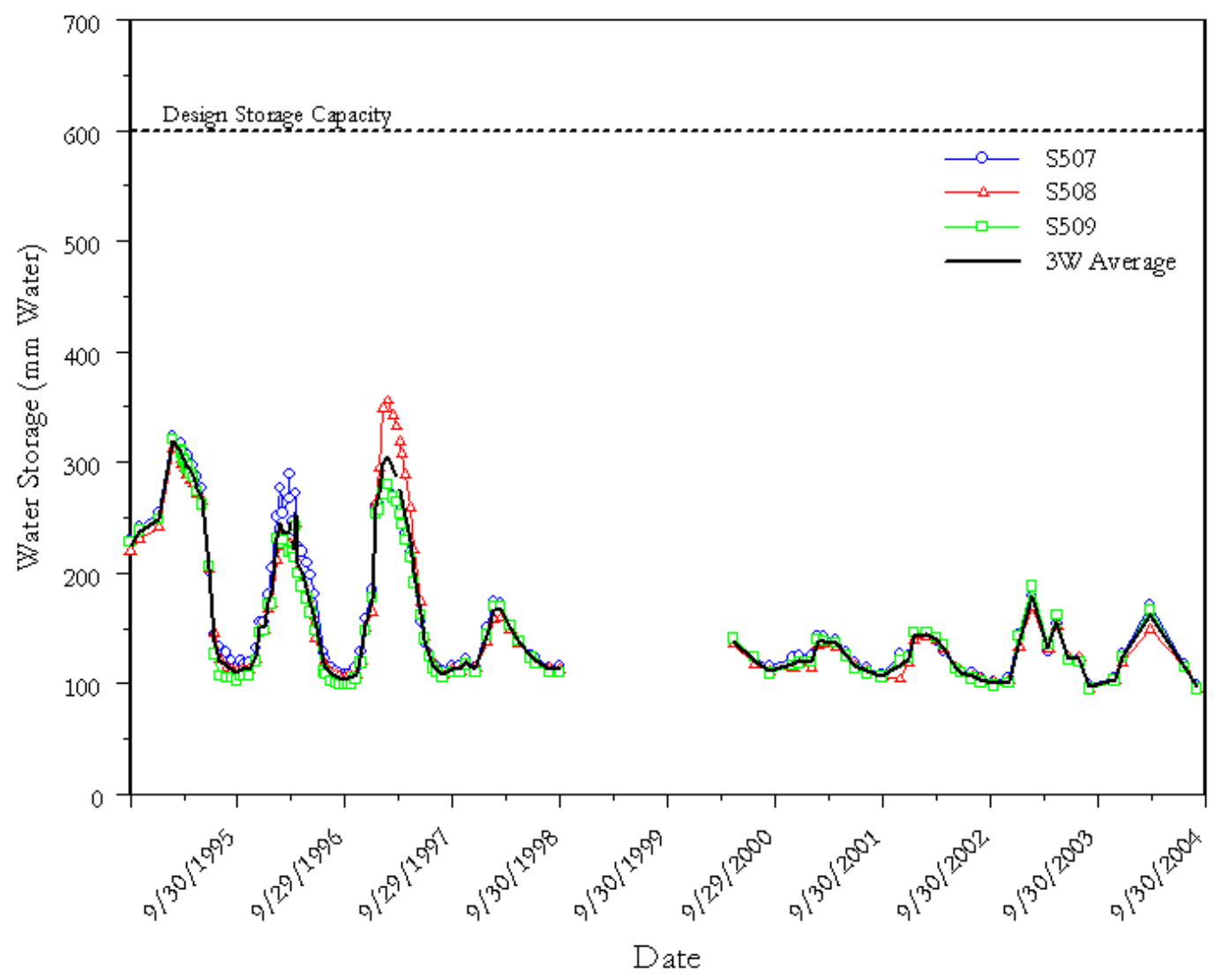

Figure 2.9. Temporal Variation in Soil-Water Storage in Northwest Plot $3 W$ at the Prototype Hanford Barrier, October 1994 Through September 2004 (design water storage capacity is $600 \mathrm{~mm}$ )

The optimal design of a candidate barrier requires close attention to the choice of plant species and may require some maintenance to ensure that the right mix of plant species remains active. Continued monitoring should provide valuable information on the plant dynamics and the time for recovery of native shrubs, such as sagebrush, after the increased stress caused by prolonged exposure to elevated precipitation. These data suggest that the effects may be quite transient, with minimal long-term influence on barrier performance. After water storage reached a record level in the winter of FY 1997 , storage peaked at slightly less than $200 \mathrm{~mm}$ in 1998 for the southern plots and well above $200 \mathrm{~mm}$ for the northern plots. The winter of FY 1997 was the wettest period since barrier construction with $138.4 \mathrm{~mm}$ of precipitation recorded. The peaks in storage have since shown a consistent decline until this year.

Another important observation is the spatial differences in water storage from plot to plot. Measurements closest to the edge of the barrier (S1 and S6) show the highest values of W at the end of summer, while the measurements near the crown of the barrier show the lowest values. This difference is most likely caused by the surface and internal topography of the barrier. As shown in Figure 2.2, there is a 2-percent slope from the crown to the edge of the barrier, both at the surface and in the internal layers. This slope could be expected to redistribute water at the surface and in the soil with a tendency for accumulation at the down-gradient positions. 


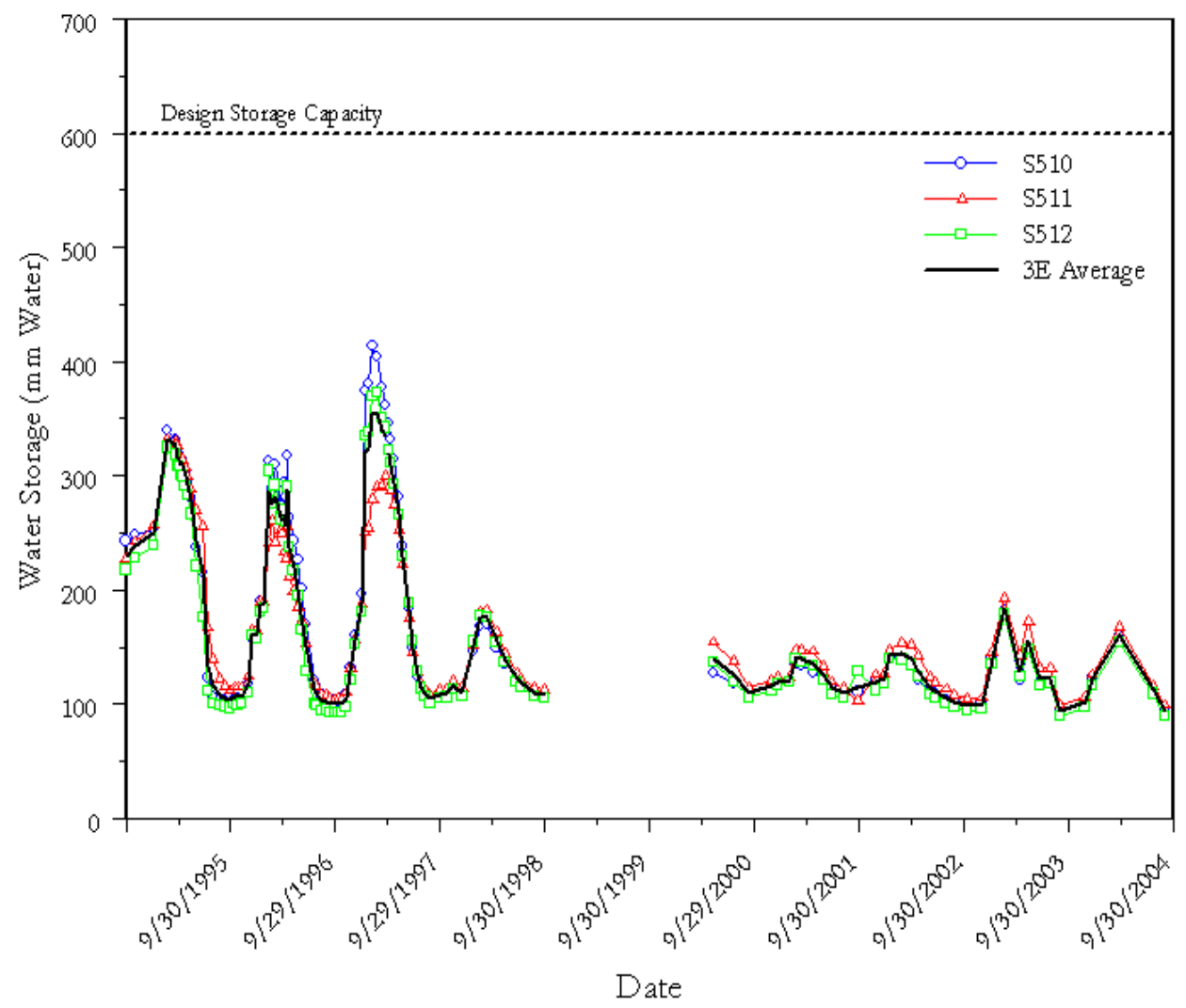

Figure 2.10. Temporal Variation in Soil-Water Storage in Northwest Plot $3 E$ at the Prototype Hanford Barrier, October 1994 Through September 2004 (design water storage capacity is $600 \mathrm{~mm}$ )

Figure 2.11 compares the mean storage on the north and south sections of the barrier. The mean storage for the north was calculated as the temporal average of $\mathrm{W}(\mathrm{t})$ measured at $\mathrm{S} 1$ through $\mathrm{S} 6$. The mean storage for the south was calculated as the temporal average of $\mathrm{W}(\mathrm{t})$ measured at $\mathrm{S} 7$ through $\mathrm{S} 12$. As of September 3, 2004, the mean storage was $100.68 \mathrm{~mm}$ on Plot $6 \mathrm{~W}$ and $99.29 \mathrm{~mm}$ on Plot 6E, compared to $96.67 \mathrm{~mm}$ on Plot $3 \mathrm{~W}$ and $94.51 \mathrm{~mm}$ on Plot 3E. In comparing water storage between plots for FY 2004, the distribution is quite similar to that observed around the same time in FY 2003. Although there are small differences between plots, differences in mean storage between plots at the end of monitoring in FY 2004 are not statistically significant. Mean storage on the north side of the barrier was $99.98 \mathrm{~mm}$ compared to $95.59 \mathrm{~mm}$ on the south side. The 4-mm difference is less than one half of the expected precision of $10 \mathrm{~mm}$ over the 2-m monitoring depth. These data highlight a convergence in measured water storage on the two sections of the barrier as time progressed beyond the cessation of irrigation.

The storage data also show that since the completion of the treatability test, the once-prominent peaks have shown a progressive decline over time except for the last two years. In the 4 years following the treatability test, mean storage rarely exceeded $150 \mathrm{~mm}$. In 2003, peak storage was closer to $200 \mathrm{~mm}$, and in 2004, the peak was around $167 \mathrm{~mm}$. This increase in peak storage over the last two years is a direct consequence of changes in precipitation and its seasonal distribution. The divergence in the lower limits of storage is also quite clear in the plot of mean storage. In the early stages of testing, the lower limits of storage between monitoring stations were quite similar but gradually diverged until 1998. This deviation 
is likely caused by interplot differences in the ability of the vegetation to recycle applied water. It also is important to note that the divergence in the lower values of storage on the north and south sections, prominent during and immediately after the treatability test, has now essentially disappeared.

Convergence to the lower limit may be partly caused by the changes in the amount and the distribution of precipitation over the last 2 to 3 years compared to previous years (Table 2.2). However, given that the southern plots of the barrier never showed the same degree of divergence during the treatability test (Figure 2.9 and Figure 2.10), the recent convergence suggests that the differences may have developed as a result of stresses caused by irrigation. The disappearance of these differences is an important observation and suggests that the native species can easily recover from relatively short-term stresses. In this case, increased stress was present for 3 years and may have been caused by elevated precipitation on the irrigated treatments.

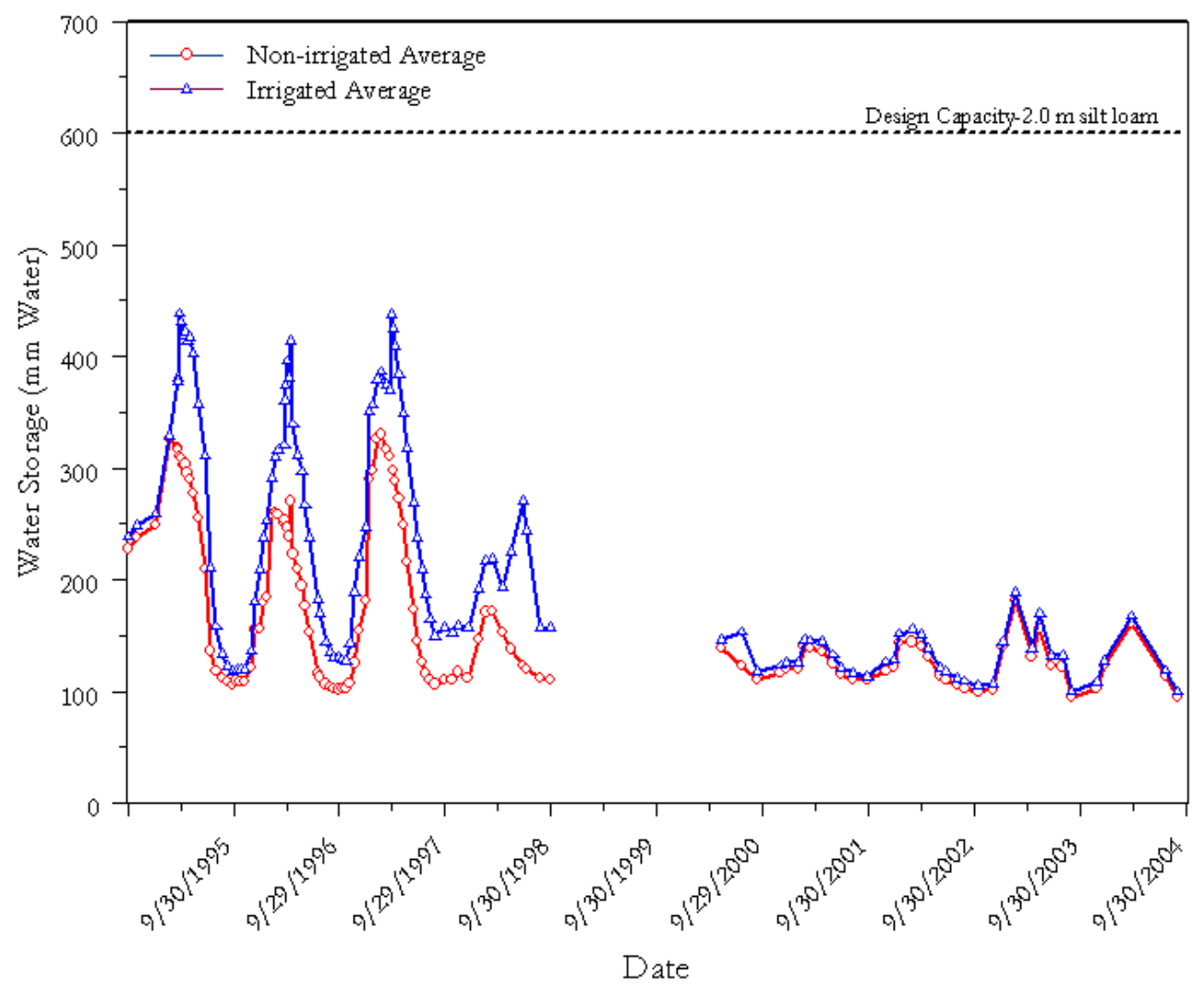

Figure 2.11. Temporal Variation in Mean Soil-Water Storage on the North and South Plots at the Prototype Hanford Barrier, October 1994 Through September 2004 (design water storage capacity is $600 \mathrm{~mm}$ )

\subsubsection{TDR Probe Measurements}

In addition to water-content measurements by neutron probe, automated measurements have been made over the last several years. In FY 2001, the remote-shorting TDR probes were replaced in an attempt to improve the accuracy of measurements in the silt-loam soil. The previous design showed low signal-tonoise ratios and high spatial and temporal variability in moisture measurements. Figure 2.12 and 
Figure 2.13 show the mean water storage derived from TDR measurements on the north and south plots, respectively, for the period March 5 through August 31, 2004.

The most striking feature in these data is the large amount of noise in the storage values, particularly on the south side. Owing to the noise, the data were smoothed with a 20-point moving average filter. The temporal changes in storage show some similarity to that observed in the neutron data, although the similarity is much stronger for the TDR data from the north plots. However, short-term changes of over 100 percent in the TDR-measured moisture contents result in apparently erratic changes in storage, even in the absence of precipitation events. The error also appears to increase with decreasing saturation. These problems appear to be more significant in the data from the south plots where erratic changes in moisture resulted in storage changes of over 300 percent. Again, the observed trends resemble the expected with an increase in storage in the winter and a decrease in the spring and summer. However, use of these data for determining absolute moisture contents or for calculating an accurate water balance may be somewhat limited. In an attempt to overcome these limitations, the frequency of probe measurements has been increased to hourly so that temporal averaging can be done. However, this approach will likely limit the ability to distinguish real short-term changes in moisture and storage that may result from episodic events such as the thunderstorms observed in May of 2004.

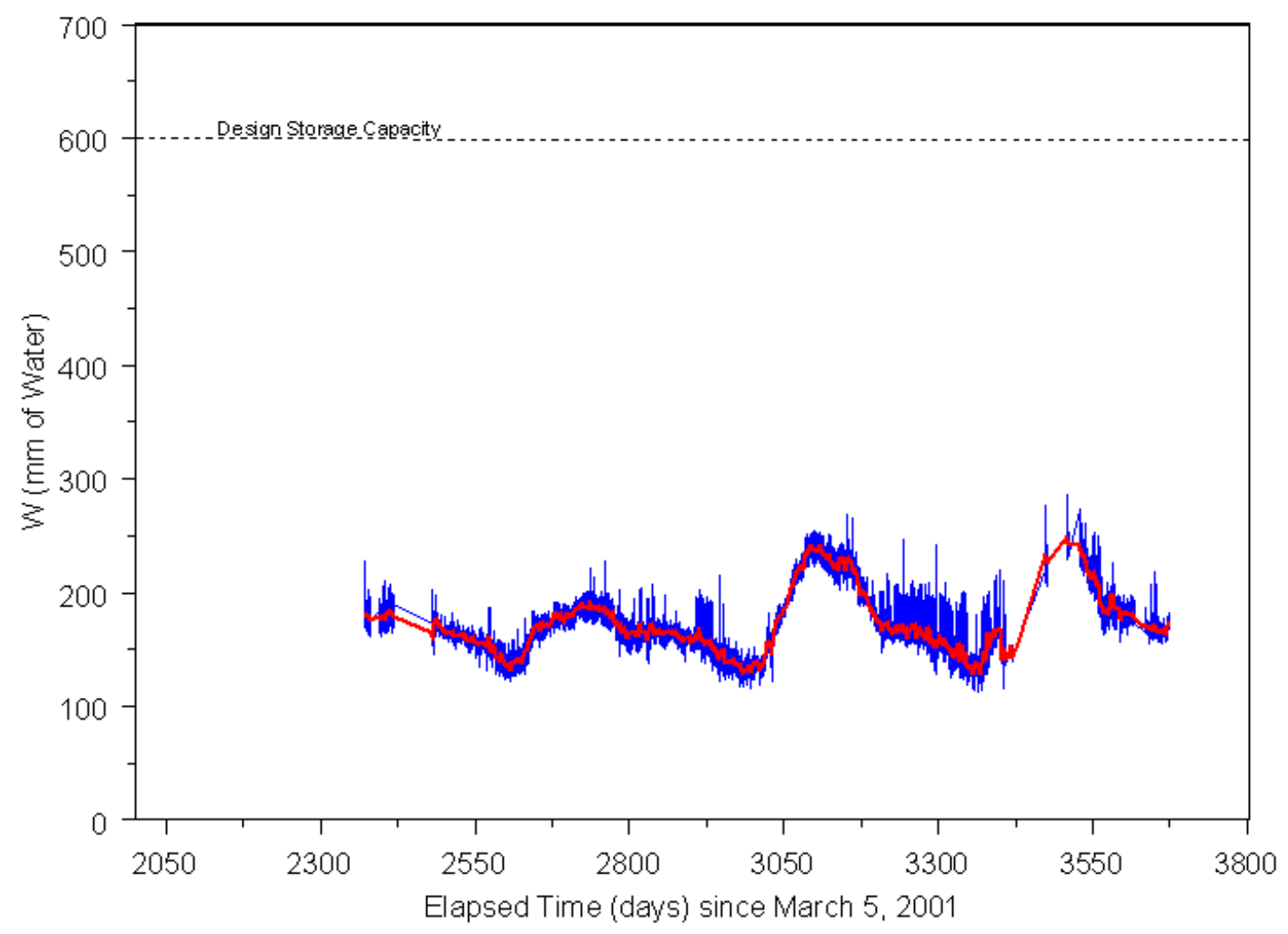

Figure 2.12. Temporal Variation in Mean Soil-Water Storage on the North Plots at the Prototype Hanford Barrier, March 51994 Through August 31 2004, Based on TDR Measurements. A 20-point moving-average filter was used to smooth the data (design water storage capacity is $600 \mathrm{~mm}$ ). 


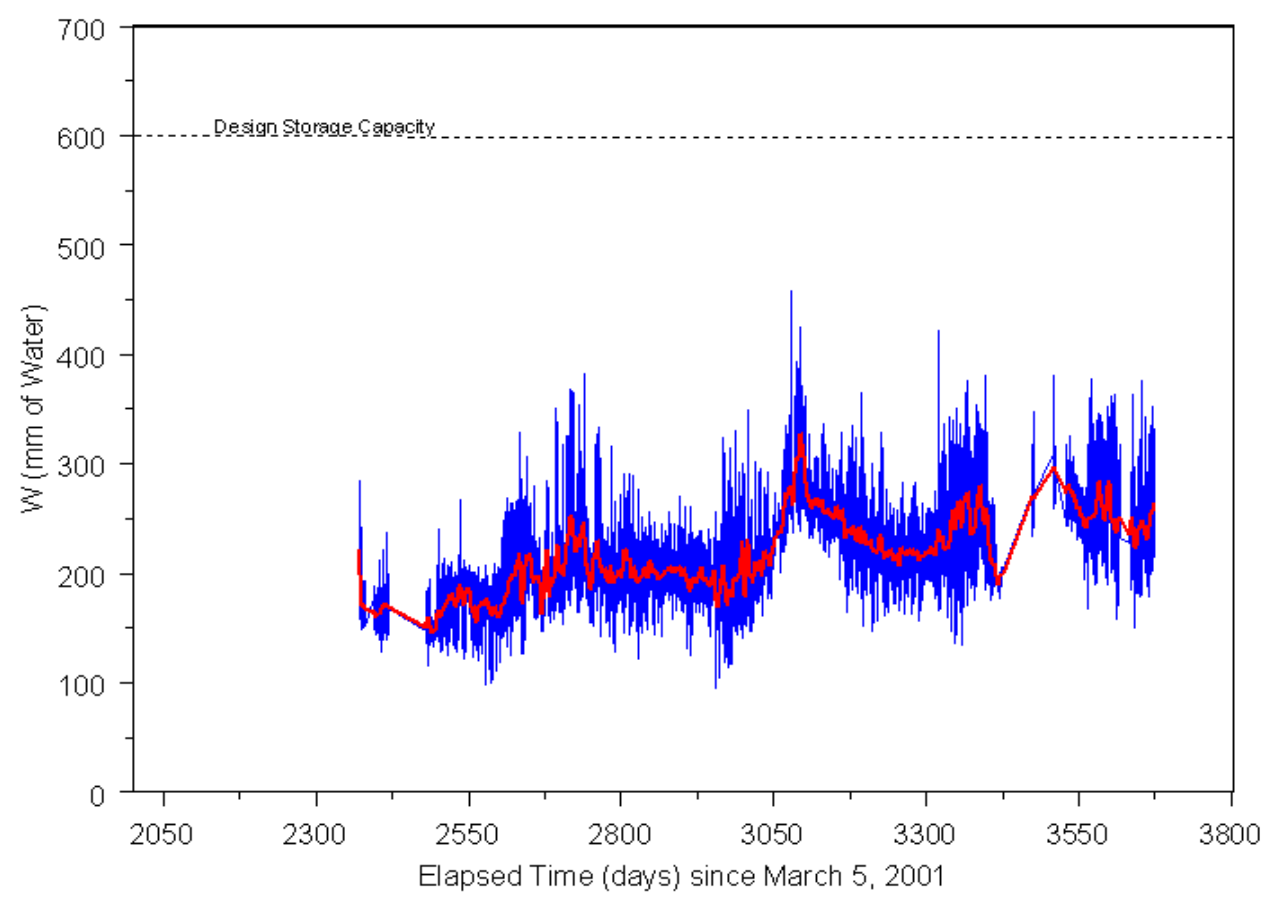

Figure 2.13. Temporal Variation in Mean Soil-Water Storage on the South Plots at the Prototype Hanford Barrier, March 51994 Through August 31 2004, Based on TDR Measurements. A 20-point moving-average filter was used to smooth the data (design water storage capacity is $600 \mathrm{~mm}$ ).

In applications where TDR measurements are made in fine- textured soils with probes attached to long cables, conventional TDR typically suffers from poor signal-to-noise ratios. As a result, moisture measurements can show a large degree of error. The Moisture Point ${ }^{\circledR}$ TDR probes in use at the prototype barrier are based on remote-diode-shorting technology that is reported to allow reliable measurements in a broader range of soil types (silts, clays, and organics) than previously possible with conventional TDR. Improved accuracy is reportedly possible through waveform differencing using remote diode shorting (Hook et al 1992). In this approach, a waveform is alternately captured with and without the probe shorted to ground at the ends of each segment. However, such improvements are not obvious in the data from the prototype barrier. The remote shorting approach has not been very popular, however, perhaps because of relatively high probe cost and the complexity of switching. The probes are now known to have a relatively small region of influence, which could limit signal penetration into the soil. Given the quality of the data observed at the prototype, claims of improved signal-to-noise and applicability to difficult soil types may not be fully warranted.

\subsubsection{ECHO Probe Measurements}

The need for robust, low-cost technologies to monitor water storage in the fine-soil layers is clearly evident, and another technology evaluated at the prototype barrier in the past year is the frequencydomain ECHO probe. Figure 2.14 shows a plot of water content derived from the recently installed ECHO probes for the period from November 27, 2002, through August 31, 2004. These data are from the gravel side slope, a material that has been difficult to instrument and monitor using traditional 
technologies. The probes show excellent response to precipitation events, registering sharp increases in water content. The response to moisture redistribution and drainage, manifested as a decrease in water content, is also quite remarkable. In fact, the thunderstorm of May 20 and 22, 2004, that is suspected to have caused erosion near the toe of the riprap slope, although difficult to distinguish from the noise in the TDR system, was clearly evident in the ECHO probe data (Figure 2.15). On May 20, Probe 1 registered a sharp increase in water content to around $0.315 \mathrm{~m}^{3} \mathrm{~m}^{-3}$ at 18:00 hrs, while Probe 2 recorded an increase to $0.262 \mathrm{~m}^{3} \mathrm{~m}^{-3}$ an hour later. Both probes showed a subsequent decrease in moisture, which is not surprising as the gravel slope has a relatively low water storage capacity. Water content continued to decrease until 17:00 hrs on May 22 when another sharp increase in moisture to $0.28 \mathrm{~m}^{3} \mathrm{~m}^{-3}$ and $0.26 \mathrm{~m}^{3}$ $\mathrm{m}^{-3}$ occurred on probes 1 and 2 respectively.

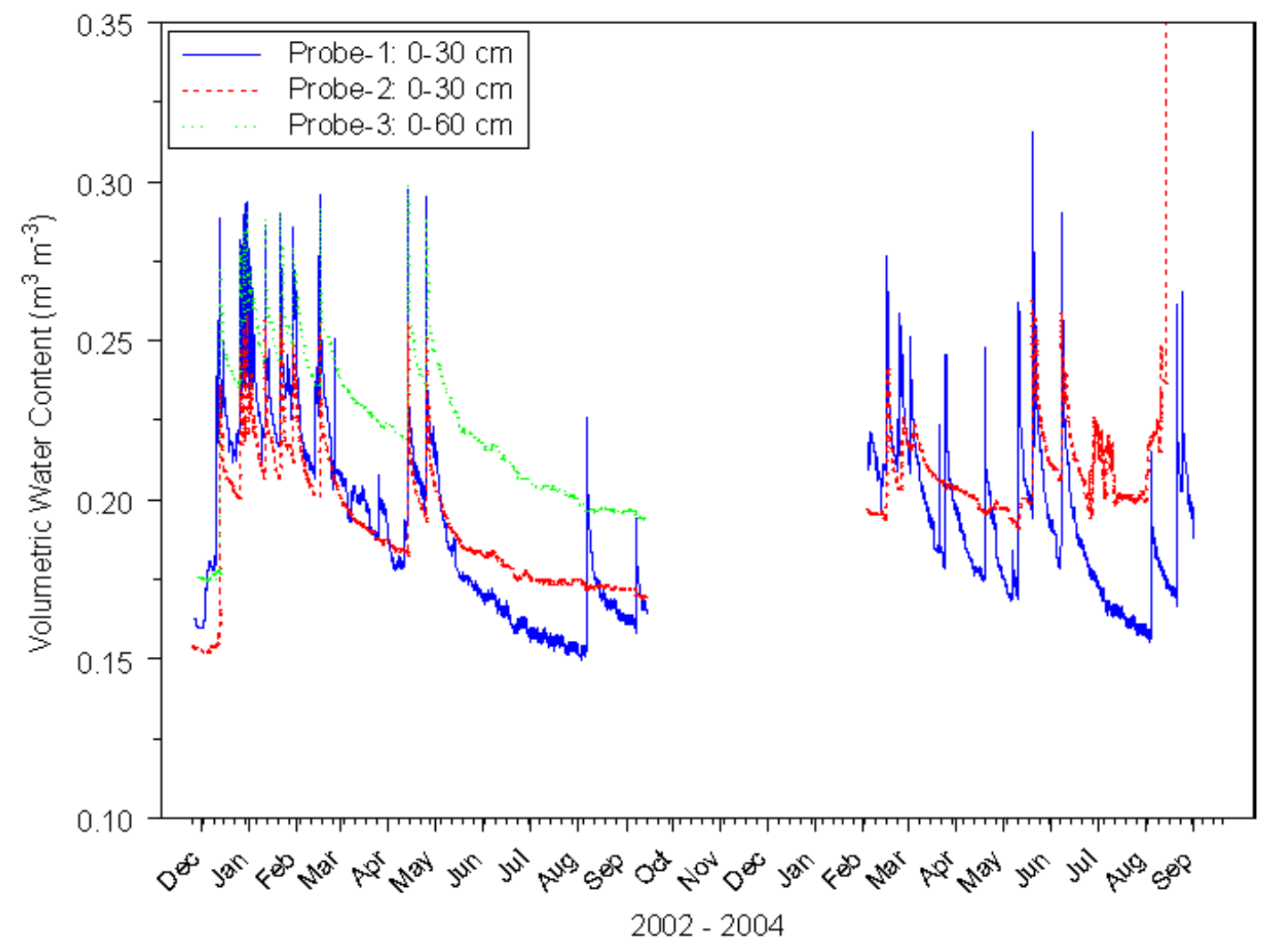

Figure 2.14. Temporal Variation in Soil-Water Content Measured by ECHO Probes on the Gravel Side Slope at the Prototype Hanford Barrier, November 27, 2002, Through August 31, 2004 


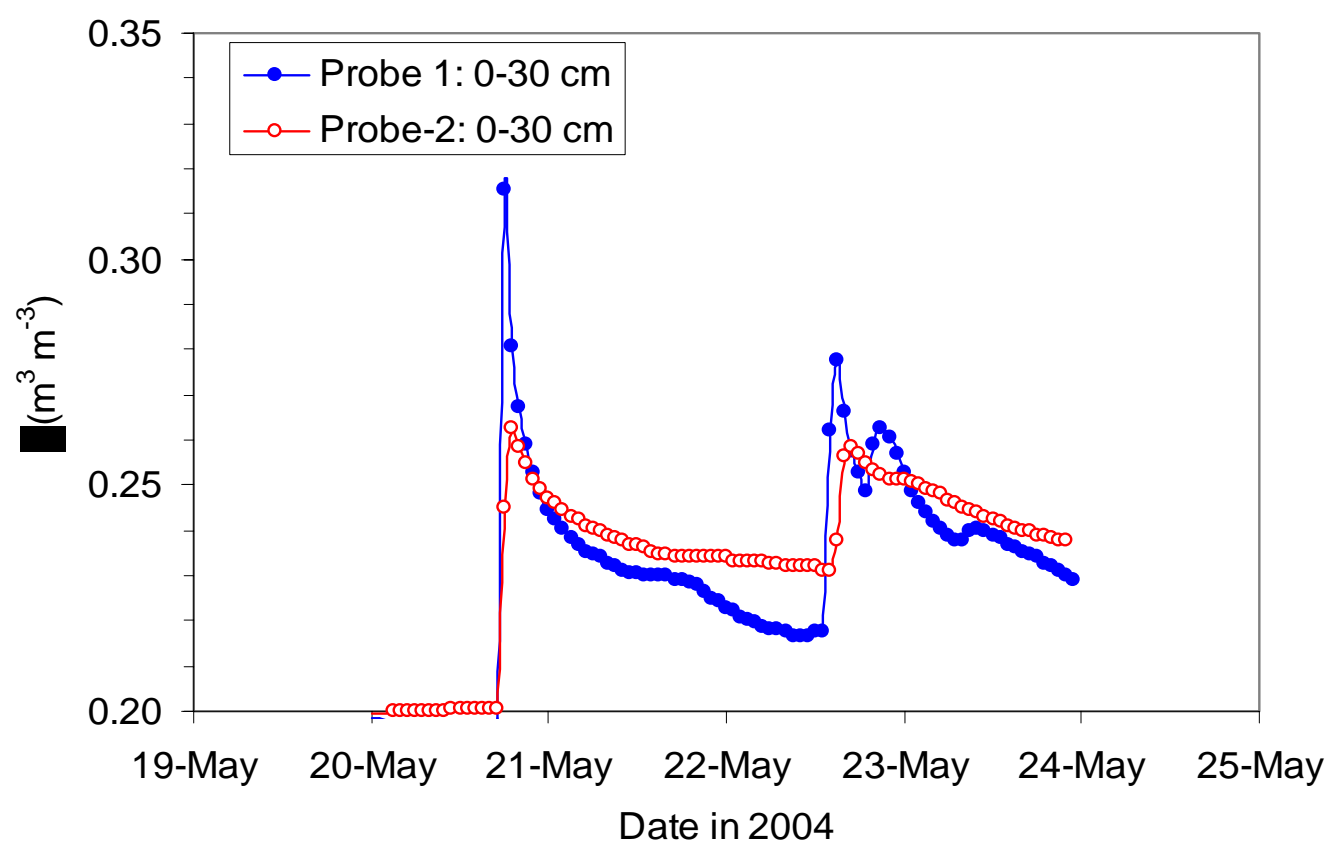

Figure 2.15. Temporal Variation in Soil-Water Content Measured by ECHO Probes on the Gravel Side Slope at the Prototype Hanford Barrier During the Thunderstorms on May 20 and 22, 2004

These probes are clearly superior to the remote-shorting diode probes, and at a fraction of the cost, they provide data of a higher quality. Although the probes show high sensitivity to changes in water storage, data storage and retrieval continue to be problematic. The system was designed to consume small amounts of power and yet transmit data over an appreciable distance. However, battery-life and datatransmission problems continue to plague the system. The system was intended to transmit data wirelessly to a station at the Field Lysimeter Test Facility from where they would be transmitted to a base station at the Pacific Northwest National Laboratory (PNNL) for automated processing and display in real time on a web page. At the base station, the data received from the field would be collected, water contents calculated, and the data reported in a simple chart. This approach had the potential to eliminate the need for costly dataloggers and monthly cell phone charges. However, it appears that the computer polling the sensor repeatedly as a means of reducing data download time adversely affects battery life of the sensor. Data collection has, therefore, been reduced to manual methods.

\subsubsection{Drainage}

Drainage monitoring continued as in previous years with measurements being recorded hourly. A 3-month monitoring hiatus occurred in FY 1999 when the dataloggers failed because of low battery voltage. Drainage values for this period were estimated by linear interpolation between FY 1998 and FY 2000. Table 2.3 and Table 2.4 summarize the drainage amounts from the eight main areas for October 1994 through August 2004. When these drainage amounts are compared to reported drainage amounts from previous years, small differences in drainage rates and cumulative amounts may become apparent. This is because all of the drainage data were reprocessed recently using upgraded software 
Table 2.3. Amounts of Water Diverted by the Asphalt Pad (Drainage) from the North Plots at the Prototype Hanford Barrier and the Relationship to Barrier Precipitation

\begin{tabular}{|c|c|c|c|c|c|}
\hline \multirow[b]{2}{*}{ Water Year ${ }^{(a)}$} & \multirow{2}{*}{$\begin{array}{c}\text { Barrier WY } \\
\text { Precipitation } \\
\quad(\mathbf{m m})\end{array}$} & \multicolumn{4}{|c|}{ Drainage (mm) From North Plots ${ }^{(b)}$} \\
\hline & & $4 W^{(c)}$ & $6 W^{(c)}$ & $6 E^{(c)}$ & $4 E^{(c)}$ \\
\hline 1995 & 467.72 & 39.88 & $3.68 \mathrm{E}-05$ & $1.20 \mathrm{E}-08$ & 19.28 \\
\hline 1996 & 480.52 & 144.06 & $1.74 \mathrm{E}-02$ & $1.40 \mathrm{E}-03$ & 171.02 \\
\hline 1997 & 514.23 & 197.27 & $1.84 \mathrm{E}-04$ & $1.81 \mathrm{E}-01$ & 246.04 \\
\hline 1998 & 169.67 & 43.92 & $1.00 \mathrm{E}-03$ & $2.10 \mathrm{E}-02$ & 31.07 \\
\hline $1999^{(\mathrm{d})}$ & 125.73 & 26.94 & $3.71 \mathrm{E}-04$ & $7.78 \mathrm{E}-03$ & 16.98 \\
\hline 2000 & 166.88 & 28.33 & 0.00 & 0.00 & 14.51 \\
\hline 2001 & 158.50 & 18.44 & 0.00 & $5.05 \mathrm{E}-03$ & 8.89 \\
\hline 2002 & 136.91 & 22.21 & $1.00 \mathrm{E}-09$ & 0.00 & 9.91 \\
\hline 2003 & 224.03 & 42.32 & $3.68 \mathrm{E}-05$ & $3.58 \mathrm{E}-05$ & 34.16 \\
\hline 2004 & 218.95 & 38.31 & 0.00 & 0.00 & 40.42 \\
\hline Cumulative & 2663.14 & 601.68 & 0.02 & 0.22 & 592.28 \\
\hline$\% \mathrm{P}$ & & 22.59 & $7.15 \mathrm{E}-04$ & $8.12 \mathrm{E}-03$ & 22.24 \\
\hline
\end{tabular}

(a) The water year (WY) corresponds to the federal fiscal year and runs from October 1 of a given year through September 30 of the following year.

(b) Drainage (D) in millimeters of water can be converted to a volume in liters by multiplying D (millimeters) by 322 on the main plots.

(c) Plot designations. Formerly irrigated plots: gravel slope $=4 \mathrm{~W}$; soil $=6 \mathrm{~W}, 6 \mathrm{E}$; basalt $=4 \mathrm{E}$. The gravel $(4 \mathrm{~W})$ and basalt (4E) slopes were not irrigated until WY 1996, although some additional water might have been added while testing the irrigation system. For these calculations, $\mathrm{P}$ is assumed to be equivalent to that on the nonirrigated plots. Irrigation ceased in September 1997.

(d) A 3-month hiatus from March 1999 through May 1999 resulted in missing data. Drainage for this period was estimated by linear interpolation between WY 1998 and WY 2000. 
Table 2.4. Amounts of Water Diverted by the Asphalt Pad (Drainage) from the South Plots at the Prototype Hanford Barrier and the Relationship to Barrier Precipitation

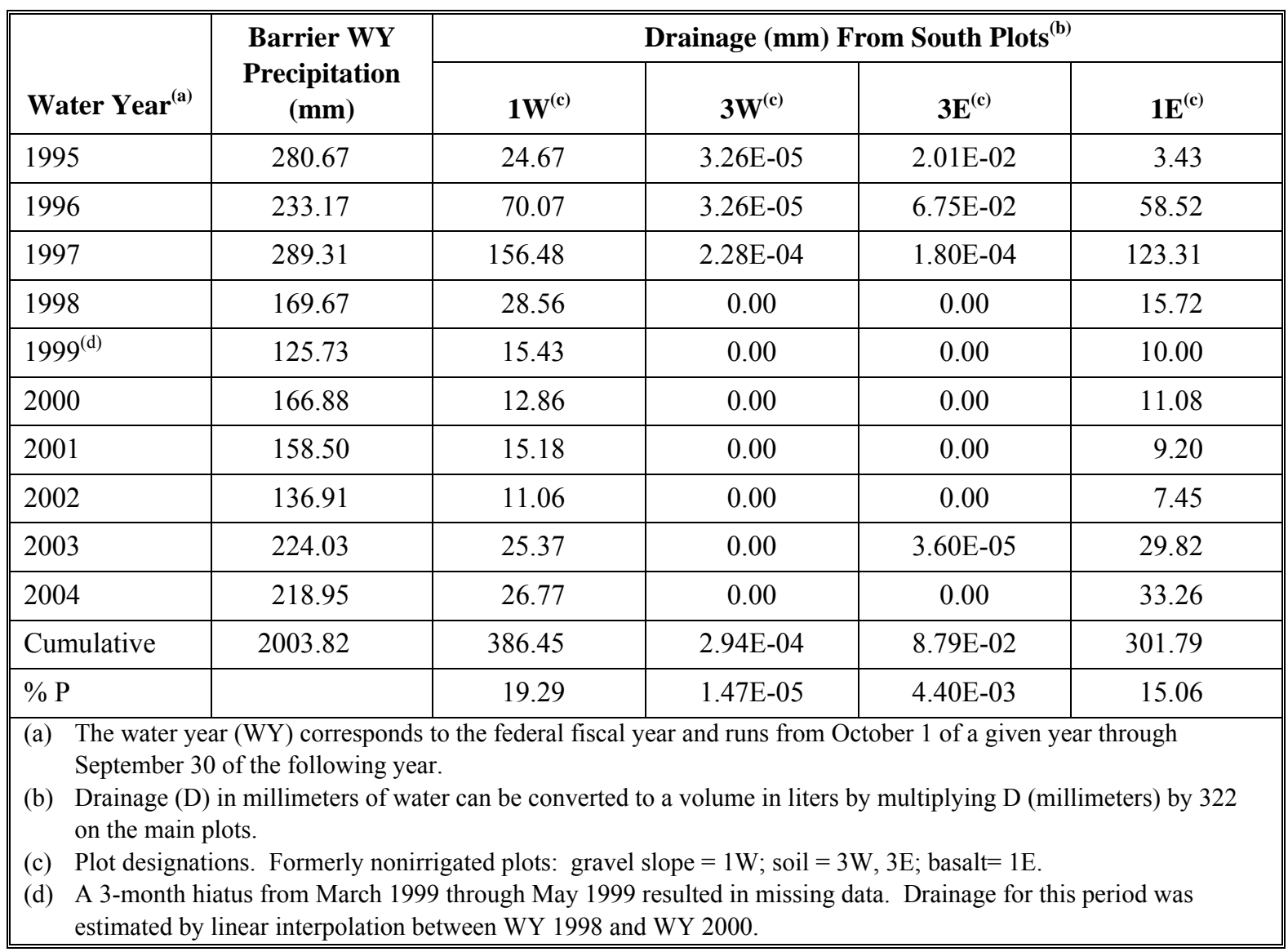

after an error was discovered in the previous software version. The differences in drainage amounts are not expected to change the conclusions drawn in previous reports. The drainage data show significant differences between the plots. Perhaps the most important observation is the extremely low amounts of drainage from the soil-covered plots. The data typically show sporadic drainage occurring from the siltcovered plots, mostly in the cooler months. The northwest soil-covered plot, $6 \mathrm{~W}$, last drained $3.68 \times$ $10^{-5} \mathrm{~mm}$, the equivalent of $12 \mathrm{~mL}$, of water in January 2003. In February of 2003, the northeast soilcovered plot $(6 \mathrm{E})$ drained a similar amount $\left(3.58 \times 10^{-5} \mathrm{~mm}\right)$, while the southeast soil-covered plot $(3 \mathrm{E})$ drained $3.60 \times 10^{-5} \mathrm{~mm}$. None of the soil-covered plots produced any drainage in FY 2004. Figure 2.16 provides a graphical summary of the cumulative drainage from the soil-covered plots for the period from October 1994 through September 2004. As of FY 2004, cumulative drainage from each the soil-covered plots is significantly less than would be expected with the $0.5 \mathrm{~mm} \mathrm{yr}^{-1}$ drainage criterion. Plots $6 \mathrm{~W}, 3 \mathrm{~W}$, $3 \mathrm{E}$, and $6 \mathrm{E}$ have generated $0.018 \mathrm{~mm}, 0.00029 \mathrm{~mm}, 0.087 \mathrm{~mm}$, and $0.208 \mathrm{~mm}$ of drainage, respectively. The higher amount from $6 \mathrm{E}$ may be related to the absence of a strong shrub population on that plot. The average drainage from these plots for the entire life of the barrier is only $0.08 \mathrm{~mm}$, which is equivalent to 15 percent of the annual drainage criterion of $0.5 \mathrm{~mm}$. These results clearly show the effectiveness of the soil-covered section in eliminating recharge. In the past, very small quantities of water were collected from the soil plots, usually in the first quarter of each year. Apart from this small seasonal discharge, no 


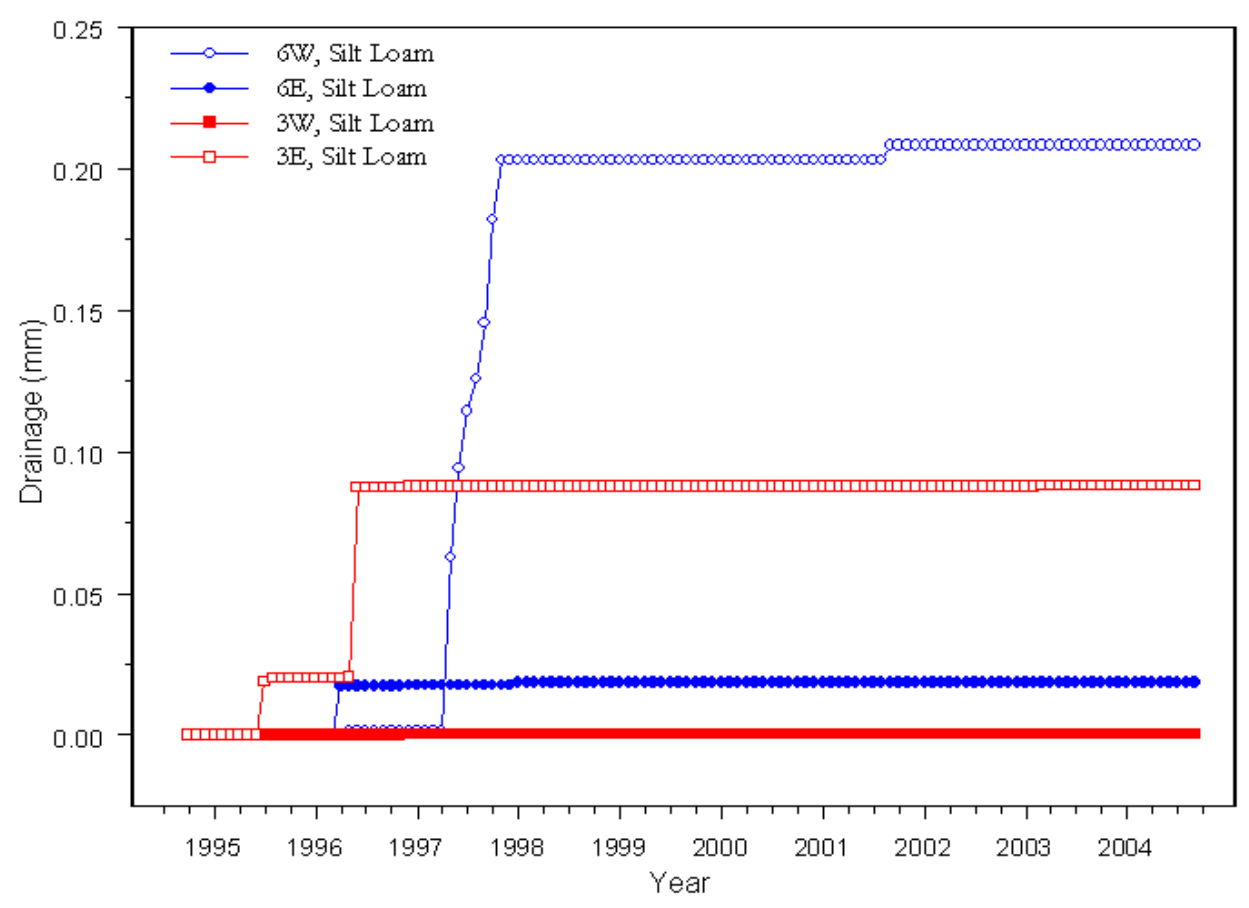

Figure 2.16. Cumulative Amounts of Water Diverted by the Asphalt Pad (Drainage) from the SoilCovered Plots at the Prototype Hanford Barrier in September 1994 Through September 2004. (Note: A 3-month reporting hiatus occurred from March 1999 through May 1999.)

drainage has occurred from the soil-covered plots. There was no drainage from the soil-covered plots in FY 2004. Figure 2.17 provides a graphical summary of the cumulative drainage from the side slopes for the same period. Unlike the soil-covered plots, the side slopes produced significant amounts of drainage. From the start of testing, drainage from the riprap side slopes showed a seasonal dependence. On the irrigated plots, riprap typically showed lower drainage rates than the gravel except in the winter months. Despite the low rates in the summer, cumulative drainage from the riprap generally exceeded that from the gravel for the duration of the treatability test. This is because drainage from the riprap was usually much higher than from the gravel in the winter months. Differences between the gravel and riprap on the north plots started to decline after reaching a maximum in the winter of FY 1997, becoming almost identical by the end of FY 2002. Since then, the drainage rates from the gravel have been increasing relative to the rates for riprap. By the end of FY 2004, the north gravel slope (4W) had drained 587.17 $\mathrm{mm}$ compared to $581.65 \mathrm{~mm}$ on the north riprap slope (4E), a difference of $5.5 \mathrm{~mm}$ (Figure 2.17).

On the non-irrigated side of the barrier, the picture is somewhat different and also easier to interpret given that there are no effects from irrigation. On the southern plots, drainage from the gravel slope (1W) has consistently exceeded that from the riprap (1E). These differences have persisted throughout the monitoring period. By the end of FY 2004, cumulative drainage from the gravel was $86.6 \mathrm{~mm}$ greater than drainage from the riprap. The discrepancy in drainage from the two slope configurations exposed to the same meteorological conditions is caused by the effects of wind pumping and water loss resulting from wind action on the riprap slope. Wind pumping with air of low relative humidity results in the evaporation of moisture from the rock surfaces, which acts to reduce drainage from the riprap slopes. 
Because of the break in monitoring shortly after the treatability test, differences between the two slopes are best determined by splitting the data into two periods. The side-slope drainage data for the south plots were split into irrigated and post-irrigated periods to gain insight into the drainage patterns. Postirrigation drainage for the period, September 30, 1998 through September 30, 2004, are shown in Figure 2.18. A comparison of the drainage from riprap slopes $1 \mathrm{E}$ and $4 \mathrm{E}$ shows a difference of only $5.6 \mathrm{~mm}$. The difference in drainage from the gravel $(1 \mathrm{~W}=95.40 \mathrm{~mm})$ and riprap $(1 \mathrm{E}=90.81)$ slopes is significantly smaller than when the entire data set is considered. This suggests that the drainage during the treatability test may have been the biggest contributor to the differences. The drainage differences also appear to be strongly correlated with precipitation. With declining precipitation over the last several years, drainage differences on the south plots also appear to be on the decline. On the north plots, drainage from the gravel slope $(4 \mathrm{~W}=156.57 \mathrm{~mm})$ is 45 percent higher than that observed on the riprap slope $(4 \mathrm{E}=107.9 \mathrm{~mm})$.

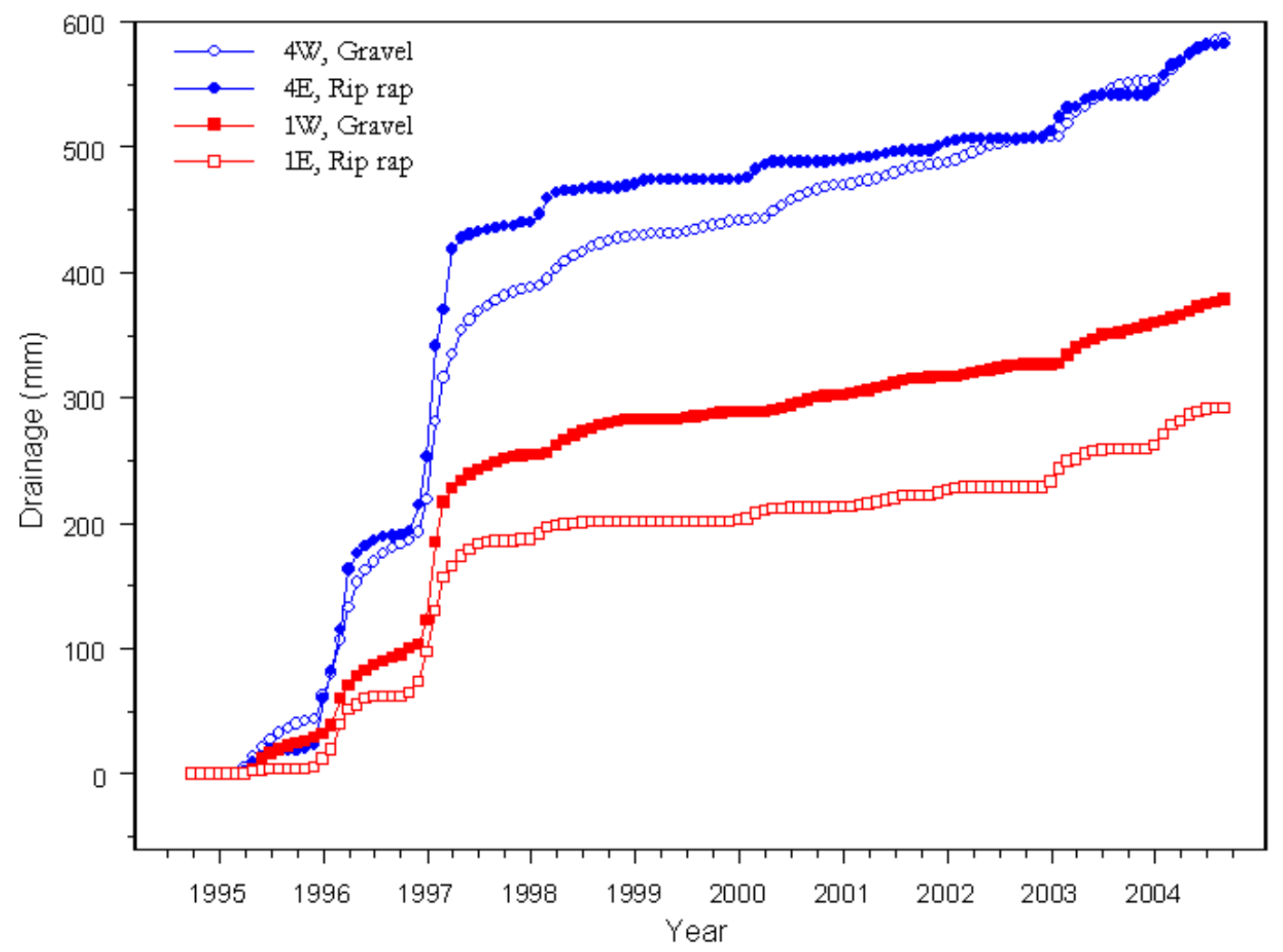

Figure 2.17. Cumulative Amounts of Water Diverted by the Asphalt Pad (Drainage) from the SideSlope Plots at the Prototype Hanford Barrier in September 1994 Through September 2004. (Note: A 3-month reporting hiatus occurred from March 1999 through

May 1999.) 


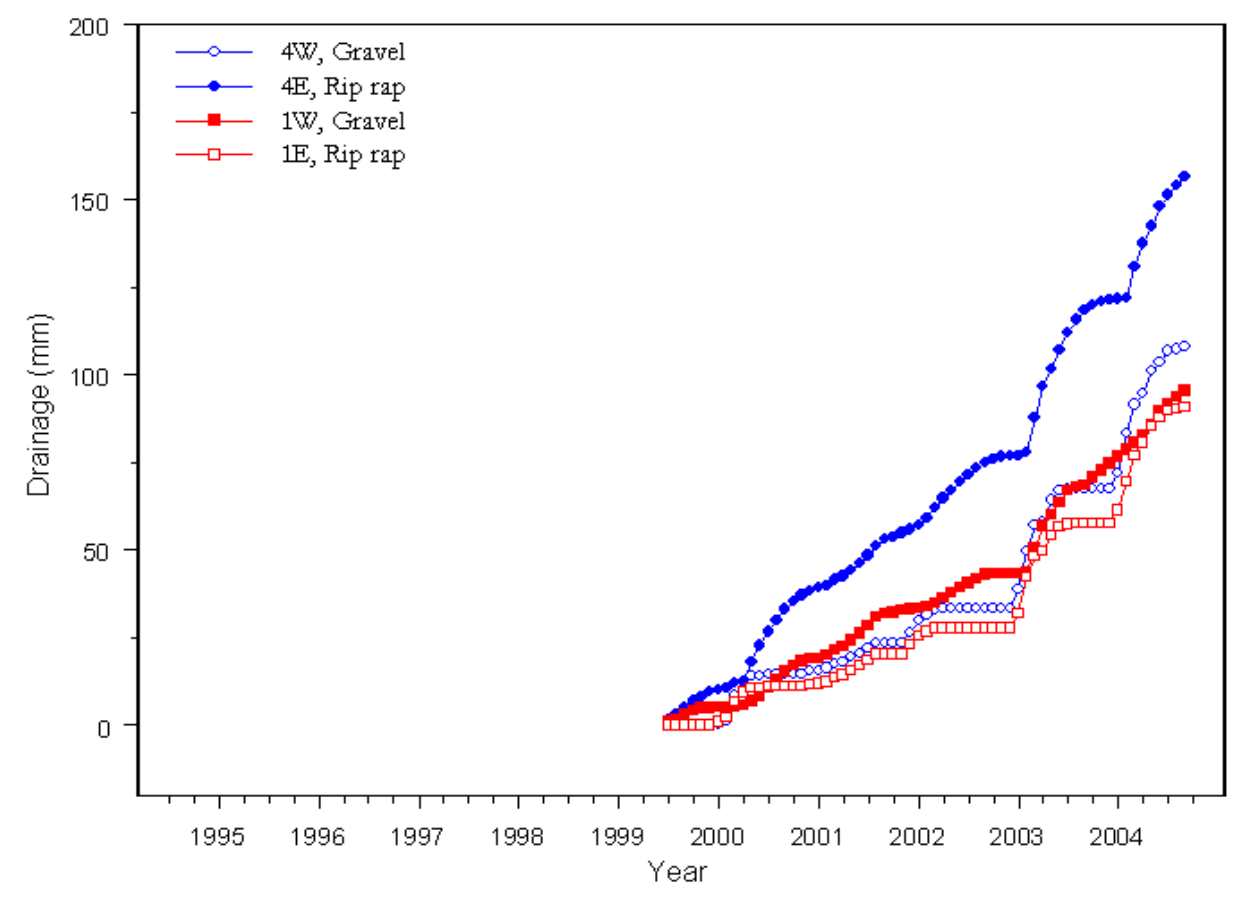

Figure 2.18. Cumulative Amounts of Water Diverted by the Asphalt Pad (Drainage) from the SideSlope Plots at the Prototype Hanford Barrier After the Treatability Test, June 1999 Through September 2004

Differences between the riprap and gravel side-slope configurations may be expected. However, drainage from similar slope configurations exposed to the same boundary conditions should be identical or nearly so. Post-irrigation drainage from the north riprap slope $(4 \mathrm{E}=107.9 \mathrm{~mm})$ is about 18 percent higher than drainage from the south riprap slope $(1 \mathrm{E}=90.81 \mathrm{~mm})$. The difference between the north gravel slope $(4 \mathrm{~W}=156.57 \mathrm{~mm})$ is 64 percent higher than drainage from the south gravel slope $(1 \mathrm{~W}=95.40 \mathrm{~mm})$. The fact that differences in drainage between north and south slopes of similar slopes are greater than between different slopes on the same side suggest an effect due to slope location that is difficult to explain at this time. The larger difference between the gravel slopes is even more puzzling. Two possible explanations have been advanced for the observed discrepancy in drainage between the gravel plots. One hypothesis attributed the difference in drainage to different leak rates from the concrete vaults in which pressure head is measured by pressure transducers. It is known that most of the vaults leak and have been doing so for several years. At the reduced levels of precipitation observed in the post irrigation period, seepage out of the $4 \mathrm{~W}$ vault could have been less than on the other three side-slope vaults, leading to an apparently higher drainage rate. A second hypothesis attributed the increased supply of water to a leaking water spigot near the irrigation hydrant. Although the water spigot was tightened in late FY 2002, the differences clearly persist. Neither of these hypotheses can be ruled out at this time.

Figure 2.19 is a grouped bar graph plot of cumulative drainage for WY 1995 through WY 2004. This plot shows that apart from WY 1997, the wettest year on record for the barrier, the 4W plot has consistently drained more than all other plots. Although the amount of drainage appears dependent on precipitation, in all years, drainage from $4 \mathrm{~W}$ has exceeded that from the other plots. It should be expected that if the larger amount of drainage was caused by a water leak that was corrected in FY 2002, differences between 
$4 \mathrm{~W}$ and other plots, particularly $1 \mathrm{~W}$, which is of a similar configuration, would be eliminated. As shown in Figure 2.19, these differences have continued through FY 2004. Data from adjacent vaults do not support the hypothesis of dramatically different vault leakage rates, leaving few possible explanations. The differences could be caused by changes in soil texture, resulting in a lower storage capacity on the $4 \mathrm{~W}$ plot than on $1 \mathrm{~W}$. A second possibility is the existence of a water-line leak other than the spigot that was tightened in FY 2002. Such a source could be eliminated by turning off the water supply to the barrier. A third possible explanation is the differences in plant cover between the two gravel plots. A lower plant density on the northwestern plot could result in lower drainage amounts compared to the southwestern plot. A lower plant density on $4 \mathrm{~W}$ would result in less water loss by evapotranspiration and an increase in drainage relative to $1 \mathrm{~W}$.

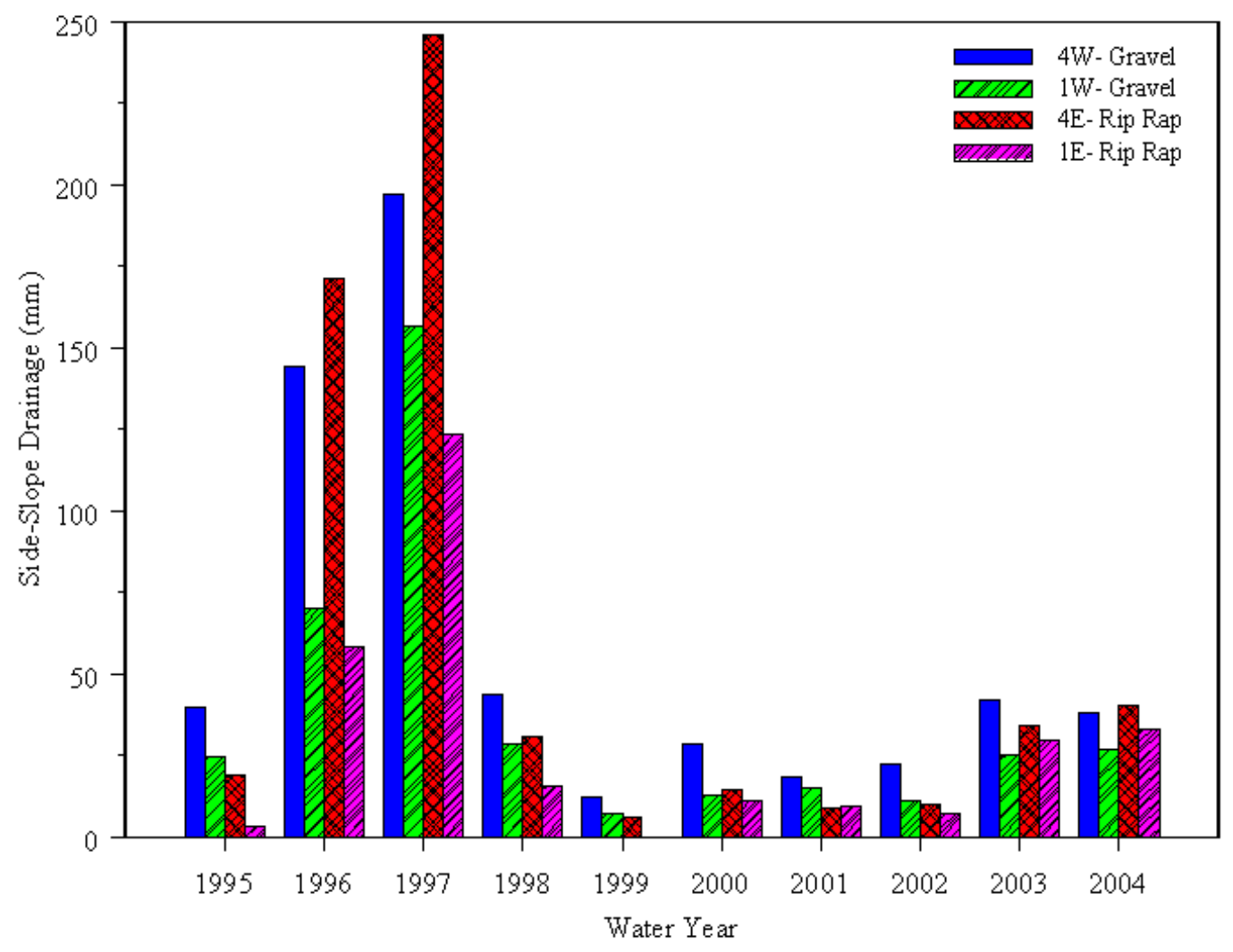

Figure 2.19. Cumulative Amounts of Water by Water Year Diverted by the Asphalt Pad (Drainage) From the Side-Slope Plots at the Prototype Hanford Barrier in September 1994 Through September 2004

Figure 2.20 shows a plot of drainage as a percentage of precipitation. Drainage from $4 \mathrm{~W}$ as a percentage of precipitation has shown a steady decline since 2002 when compared to $4 \mathrm{E}$, thus lending some support to the hypothesis of a leaking water line. Efforts will continue to determine the cause of this discrepancy. Although the barrier was not originally instrumented to permit a comparison of drainage as a function of slope position, the recent installation of water fluxmeters on the gravel slope was intended to provide some insight into this phenomenon. 


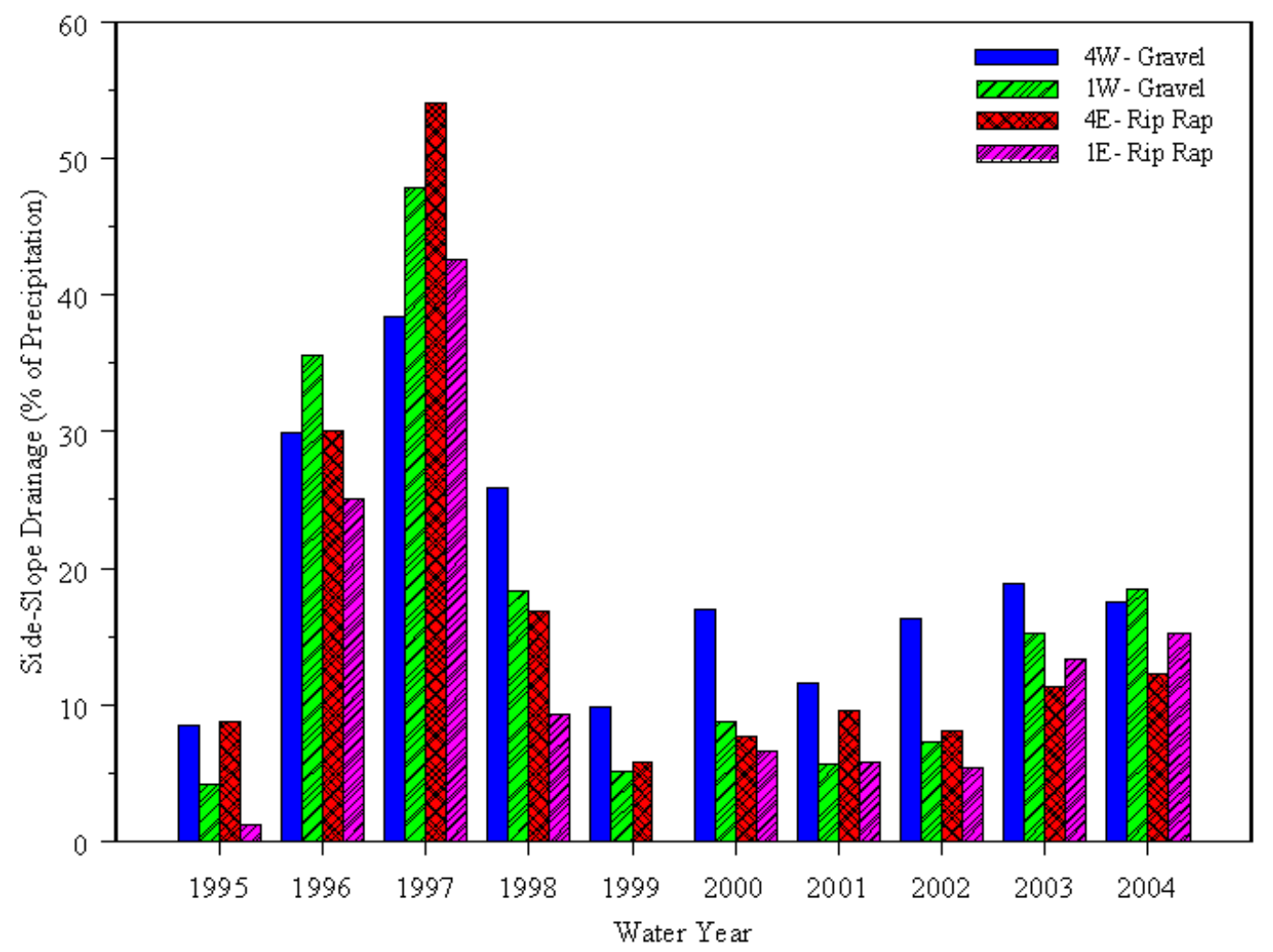

Figure 2.20. Cumulative Amounts of Water by Water Year Diverted by the Asphalt Pad (Drainage) From the Side-Slope Plots at the Prototype Hanford Barrier in September 1994 Through September 2004 as a Percentage of Precipitation

Figure 2.21 and Figure 2.22 compare drainage volumes from Plot $4 \mathrm{~W}$ derived from vault measurements and water fluxmeters installed at upper and lower slope positions. The data shown are for the period May 1 through 31, 2004 (Figure 2.21), and June 1 through 302004 (Figure 2.22) when a series of thunderstorms discussed earlier occurred. The rapid response from the fluxmeter to rainfall events is due to the divergence-control device that extends to the surface. While even the smallest events are captured by the fluxmeters, these events are not readily apparent from the vault measurements. This is due to the storage capacity of the gravel slope. Because of a small but nonzero storage capacity of the gravel, the depth over which the water must travel before it is redirected to the vault, and the possibility of lateral flow before the water reaches the collection area, a damped response can be expected. With the current configuration, the fluxmeters provide point measurements of drainage and would be best quantifying episodic events. The large lysimeters provide a better measure of long-term drainage rates with much greater precision. 


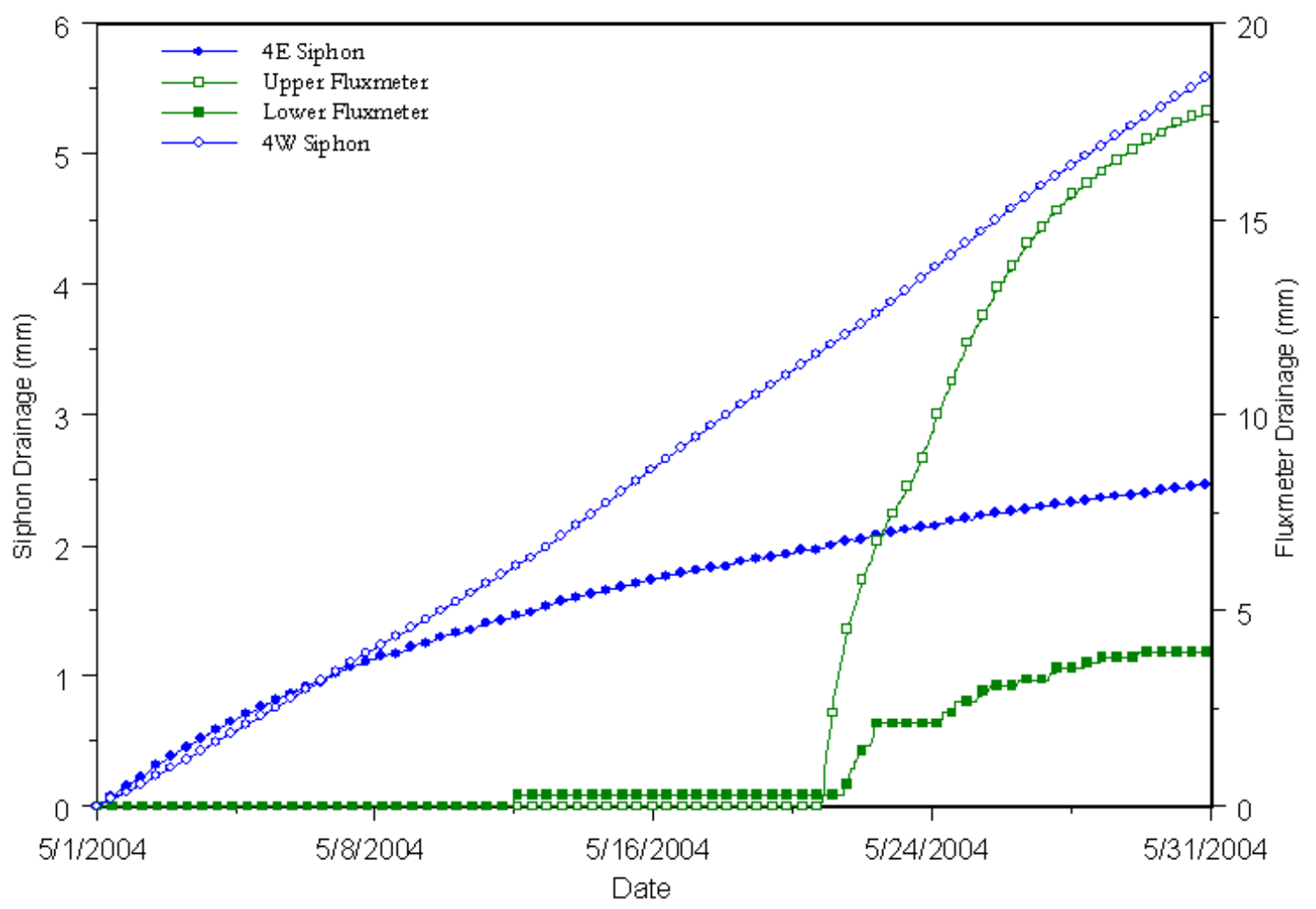

Figure 2.21. A Comparison of Cumulative Amount of Water Diverted by the Asphalt Pad (Drainage) Under the Gravel Side Slope as Measured by Pressure Transducers in the Siphons Vaults and a Water Fluxmeter for the Period May 1, 2004, through

May 31, 2004

None of the above factors can explain the difference in drainage recorded by the two fluxmeters or between the fluxmeters and the drainage vaults. In both months, there was a significant difference in drainage between the two fluxmeters. Drainage from the upper fluxmeter was higher in both months. At present, the reason for this difference is unclear. The observed differences could be caused by differences in evaporation rates from the fluxmeters, ponding of water on the fluxmeters, run-on of surface water from the road to the upper fluxmeter, the effects of vegetation, or a simple malfunction. Examination of the fluxmeters and the surrounding environment rules out most of these possibilities. The fluxmeters and the immediate surroundings are free of plants; run-on of surface water would have also impacted the drainage recorded by the siphons, and there is no evidence of this. Examination of the near-surface soil shows no obvious difference in texture that could explain the difference in response.

To gain further insight into the problem, the entire time history of drainage from the two fluxmeters was compared with drainage from the side slopes. Fluxmeter measurements started on November 27, 2002 and the data are reported through September 17, 2004. Figure 2.21 presents a summary of precipitation and drainage for this period. For the period, a total of $406.65 \mathrm{~mm}$ were recorded and the upper fluxmeter showed strong correlation with precipitation. For the period of interest, the upper fluxmeter recorded $193.45 \mathrm{~mm}$ or 48 percent of precipitation. Drainage from the lower fluxmter, however, was typically less than the upper fluxmeter. Observation of the drainage record shows that lower fluxmeter may have 


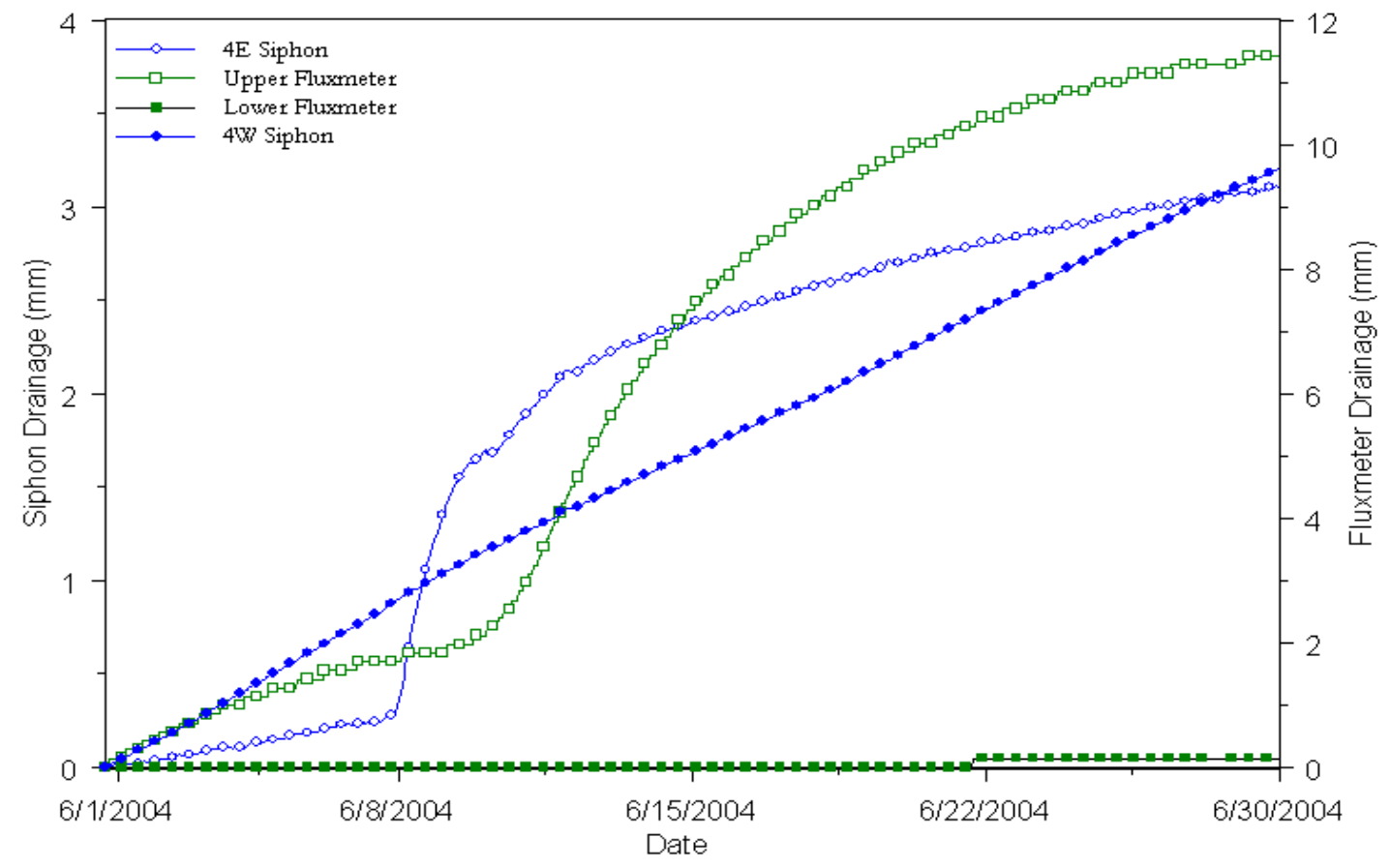

Figure 2.22. A Comparison of Cumulative Amount of Water Diverted by the Asphalt Pad (Drainage) Under the Gravel Side Slope as Measured by Pressure Transducers in the Siphons Vaults and a Water Fluxmeter for the Period June 1, 2004, through June 30, 2004

malfunctioned in early March 2003. The unit recorded zero drainage until around June 2004 and the total amount of drainage for the period of interest was only 20 percent of precipitation. Thus, a malfunction in the lower fluxmeter is the most likely explanation for the discrepancy. Drainage recorded in the gravel siphon vault (4W) was $79.64 \mathrm{~mm}$ or 20 percent of precipitation, while $74.59 \mathrm{~mm}$ or 18 percent of precipitation was recorded in the riprap vault $(4 \mathrm{E})$. The difference in drainage from the fluxmeter and siphon vaults is most likely due to evaporation (4E) and evapotranspiration (4W) losses from the side slopes. Because the fluxmeters extend to the surface and free of plants, they represent a true estimate of water draining through the porous medium minus some evaporation that might occur from wet surfaces. The fluxmeter units will be recalibrated in FY 2005 to determine if equipment malfunction is responsible for the differences. 


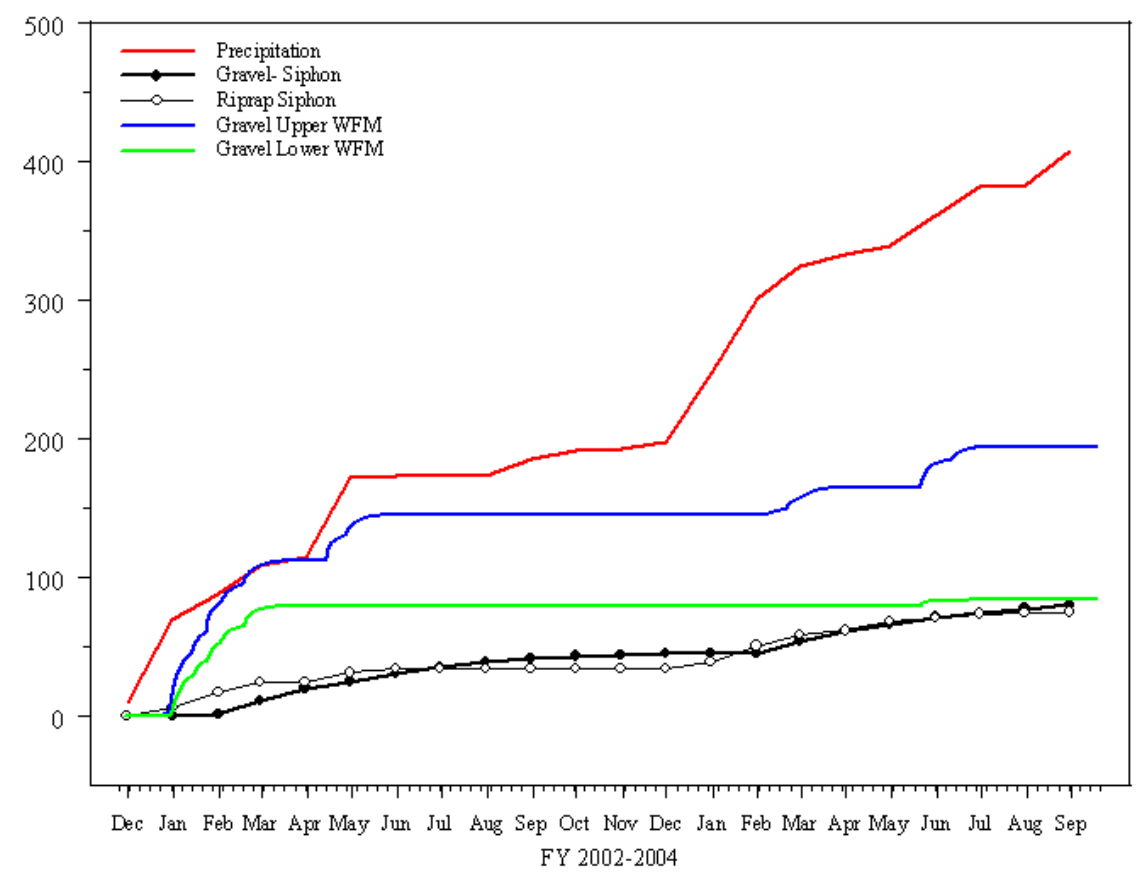

Figure 2.23. A Comparison of Cumulative Amount of Water Diverted by the Asphalt Pad (Drainage) Under the Side Slopes Measured in the Siphons Vaults and Water Fluxmeters for the Period November 27, 2002, through September 17, 2004

\subsubsection{Surface Runoff and Erosion}

The runoff monitoring flume was refurbished in June after site inspection showed that a pipe leading from the runoff plot to the flume had become disconnected. Despite the temporary loss of monitoring capabilities for runoff, there is no evidence of runoff from the barrier surface. No runoff was recorded in FY 2004; thus, $R=0$ in the water-balance equation (Eq. 2.1). Although there is no evidence of runoff form the prototype barrier, there is evidence of runoff and significant erosion at the adjacent BX Tank Farm.

During a trip to the prototype to collect data, significant water erosion was observed near the toe of the riprap slope on the east side of the barrier. It appears that during one of the thunderstorm events described above, most likely the May 20 storm, water collected on the bermed tank farm surface on the northwestern corner of the BY Farm. The ponded water eventually breached the runoff control berm that eroded the berm during the overflow. This water may have flowed down the north-western slope of the tank farm, eroding the gravel armor in its path (Figure 2.24a). A similar occurrence was reported to have caused erosion damage adjacent to BX and BY tank farms. Surface water runoff collected south of the BX to B Tank Farm waste transfer line berm on the west side of Baltimore Avenue. The ponded water overtopped the berm, eroding the berm and exposing the out-of-service waste transfer line. The released water flowed to the north along the west side of Baltimore Avenue and then through the 18-inch culvert under 12th Street (Rick Heath, personal communication, 2004). 
The runoff water from the elevated BY-BX Tank Farm plateau flowed down-gradient to the region between the tank farm and the prototype barrier, damaging the west fence and eroding a channel over 40 -inches deep at the base of the barrier side slope (Figure 2.24b, Figure 2.24c). The erosion channel extends well into the structural base fill of the barrier (Figure 2.24c, Figure 2.25) and may need to be refilled in accordance with geotechnical specifications. The migrating sediment has covered the lower horizontal under-asphalt access tube for the neutron probe, cutting off access to this tube for monitoring. The runoff water continued to flow north, picking up fine-textured sediment in its path from the riprap toe slope and eventually collecting ponding water on the stabilization fill near the BY Cribs (Figure 2.24c, Figure 2.25). The light colored region in Figure 2.24c and Figure 2.25 is the area where the ponding occurred. The light-colored material is the sediment remaining after the ponded water infiltrated and evaporated from the surface.
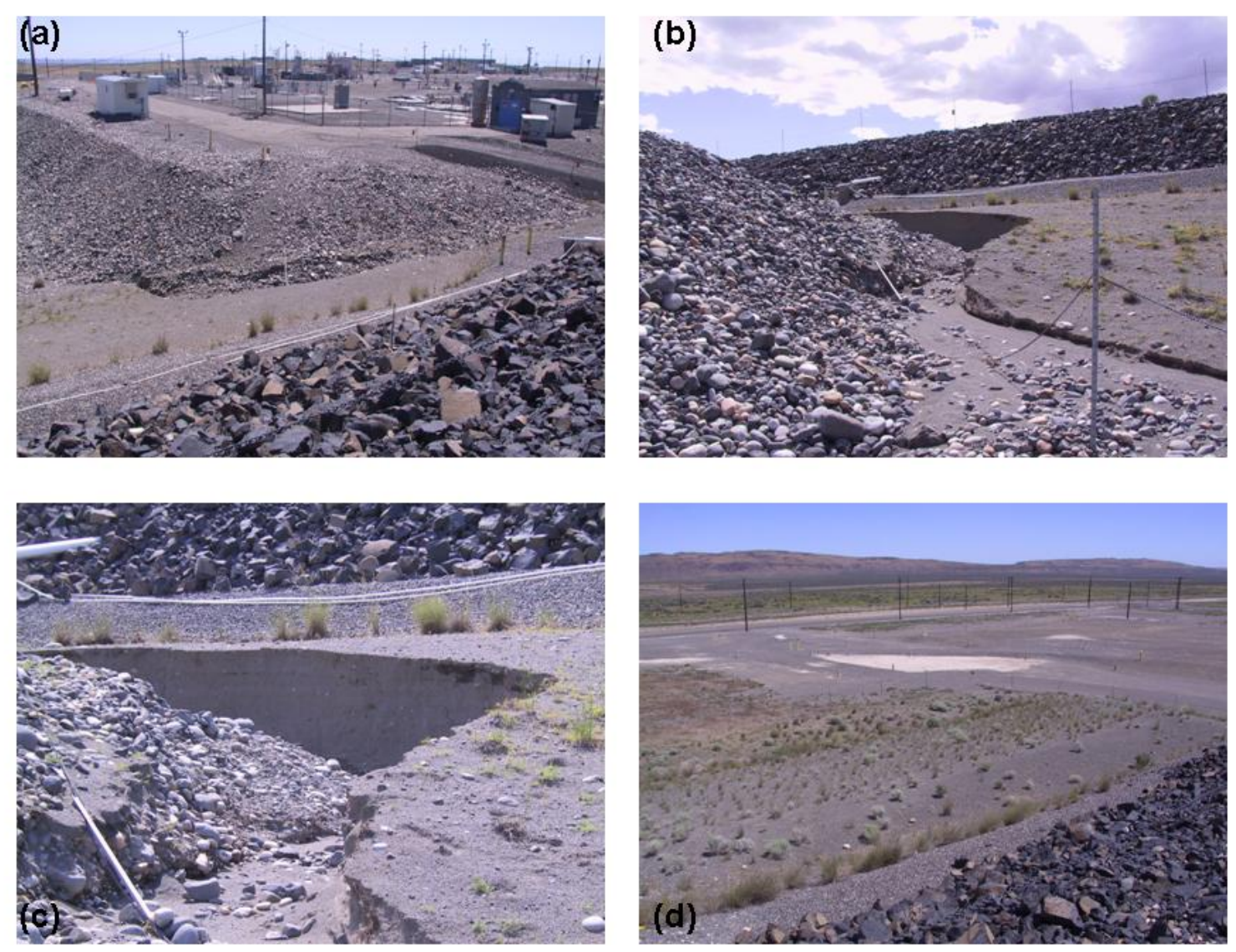

Figure 2.24. Evidence of Erosion Near the Prototype Barrier Resulting from a Thunderstorm in May 2004; (a) elevated surface of the BY Tank Farm showing part of water control berm and the eroded northwestern slope, (b) damaged fence and erosion channel formed between BY Farm and the prototype barrier, (c) erosion channel, over 45 inches deep in places, cut into the barrier structural fill, (d) fine-textured sediment remaining near the BY Cribs after infiltration and evaporation of the runoff water. Photographs by Chris Strickland of PNNL. 
Figure 2.25 is a photograph taken on 6/16/04 (looking to the north from the BY tank farm) during an inspection by Kirk Christensen and Curt Wittreich. This photograph shows the erosional channel between the east side slope of the 200-BP-1 Prototype Hanford Barrier (left side of photo) and the west side slope of the BY Tank Farm (right side with cobbles). The channel, with depths over 45 inches in places, extends into the sandy structural fill layer of the riprap toe slope. The light colored area (fine soil deposit) behind the vehicle at the top of the photo indicates an area of ponding.

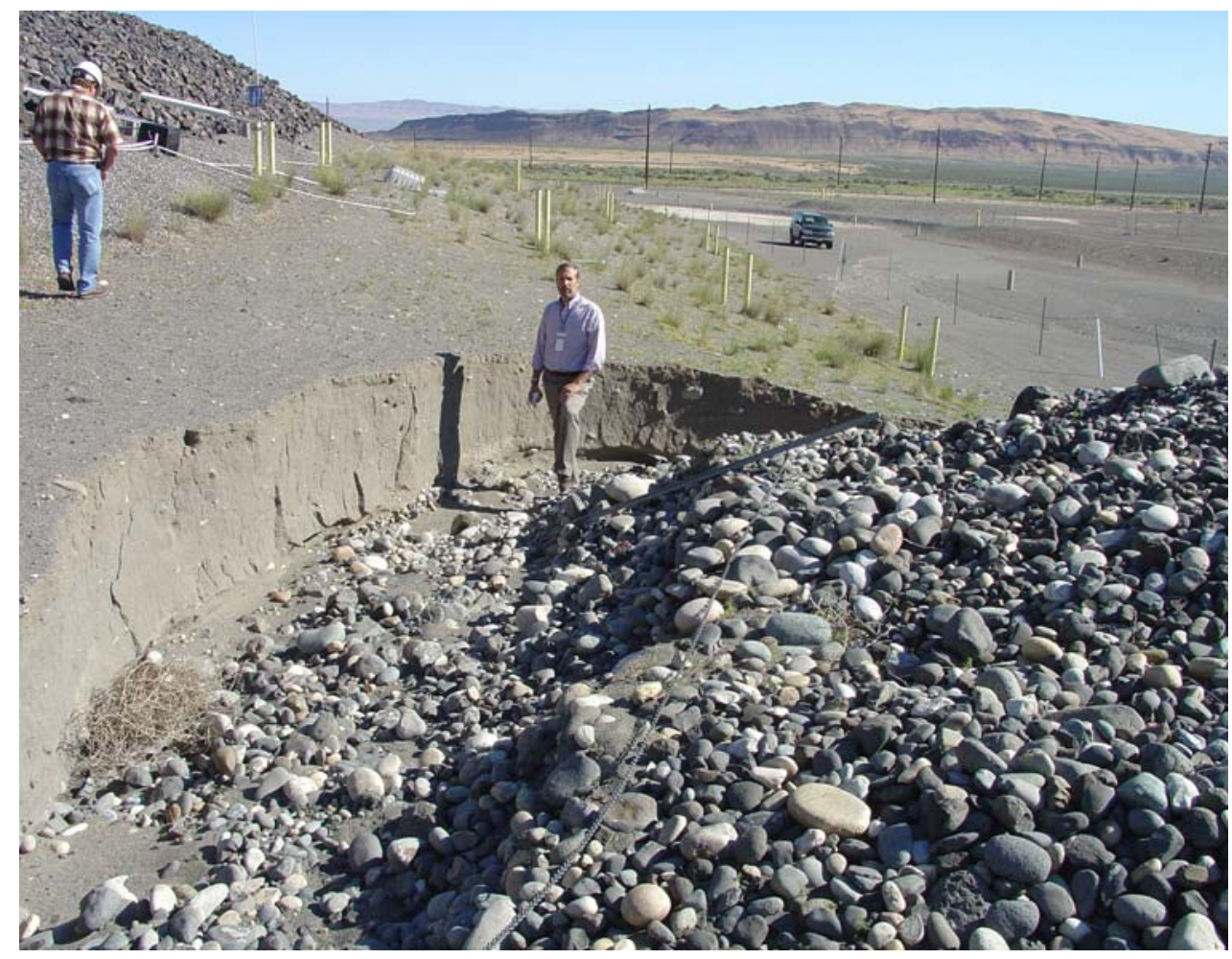

Figure 2.25. North-Facing Photograph Taken on 6/16/04 from the BY Tank Farm During an Inspection by Kirk Christensen and Curt Wittreich (standing in channel). The light colored area behind the vehicle is the fine-textured sediment remaining after the ponded runoff water infiltrated and evaporated adjacent to the BY Cribs.

\subsubsection{Deep Percolation}

Monitoring of the under-asphalt lysimeter located in the northeastern corner of the barrier continued through the year, and there was no evidence of percolation through the asphalt layer. The absence of deep percolation is also supported by horizontal neutron-probe measurements of soil-water content at the silt capillary break and below the asphalt layer. Figure 2.26 compares plots of water content as a function of space and time at the northern (irrigated) half of the barrier (neutron tubes AA1 + AA5 and AA2 + AA6) from November 1994 through September 2004. These plots represent water content measured to within $1 \mathrm{~m}$ of the barrier crown in the $\mathrm{u}$-shaped tubes just above the capillary break. The $\mathrm{x}$-axis represents 
horizontal distance from the center of the barrier with a positive ordinate to the east of center (toward the riprap side slope) and a negative ordinate to the west of center (toward the gravel side slope).
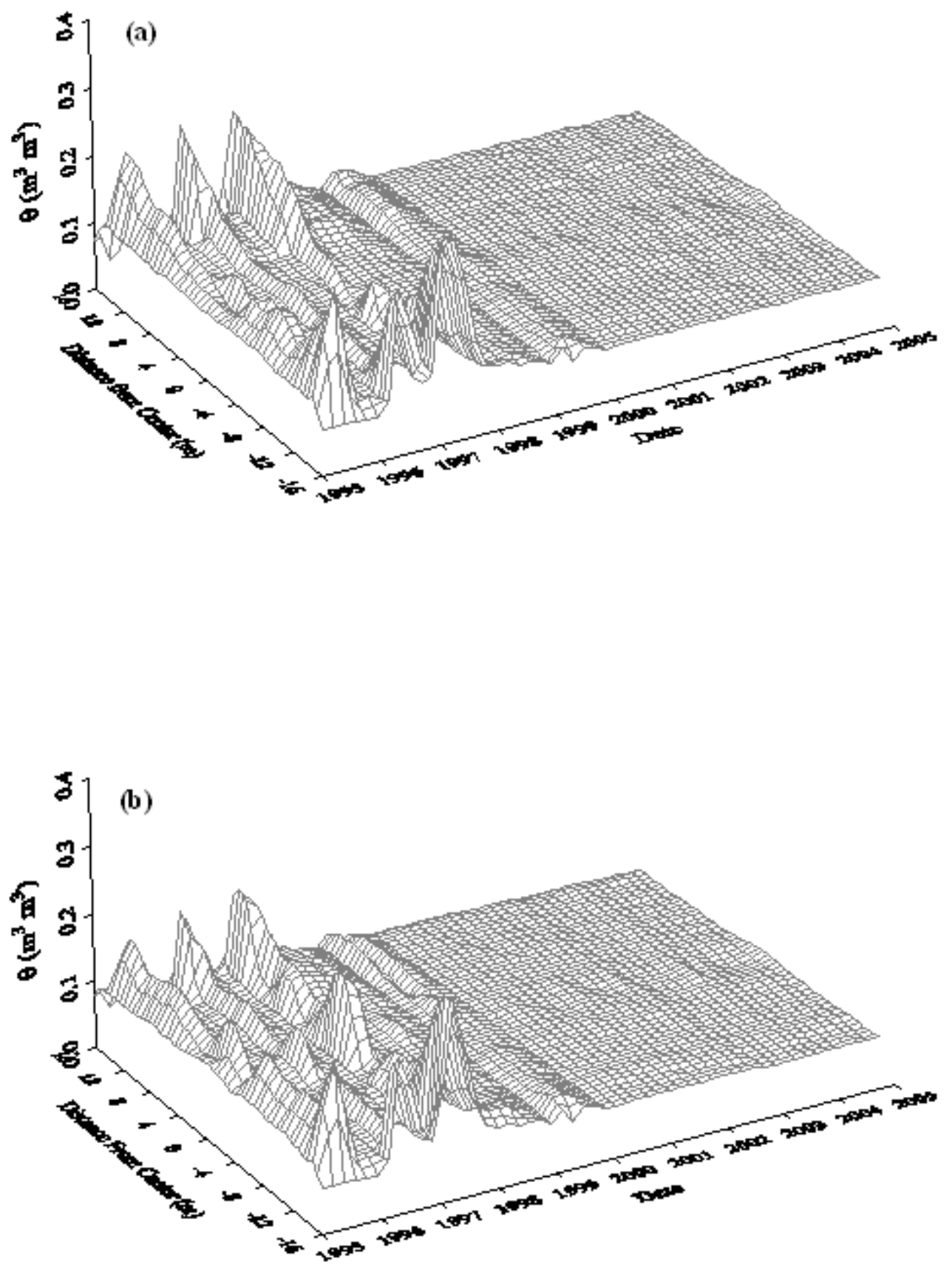

Figure 2.26. Spatiotemporal Variations in Soil-Water Content at the Bottom of the Silt-Loam Layer of the Irrigated Treatment of the Barrier: (a) northern end of treatment, tube AA1 + AA5, and (b) southern end of treatment, tube AA2 + AA6 
Early in the monitoring-program testing, water content showed a clearly defined cycle at the capillary break, increasing in the winter, reaching a maximum in late spring, and decreasing over the summer. Figure 2.27 shows similar plots for the southern, nonirrigated section (AA3 and AA4). Water decreased within the first few months of surface revegetation and remained unchanged throughout most of the test period. This trend also showed a dramatic change in WY 1997 when infiltration appeared to have been focused along the edges, as observed in the northern section. As observed on the northern section, water content at the capillary break has shown a steady decline over the last several years with no evidence of seasonal cycling. Apart from the short-term changes in moisture observed during the early stages of the treatability test, changes in moisture content have been unremarkable over the last several years.

These data clearly show that water content decreased at the capillary break since the completion of the treatability test. There is also no evidence of water penetration along the edges. Both the north and south plots show that the greatest accumulation of water occurred during periods of elevated precipitation. This accumulation occurred under the transition surface plots $(5 \mathrm{~W}$ and $5 \mathrm{E})$ of the prototype as shown by the elevated levels at the east and west edges. Elevated water contents at these locations are most likely caused by the sloped interface between the silt loam and coarser shoulder ballast, which forms a capillary break. Such a configuration could facilitate the downward movement of water along the interface between the silt loam and side-slope material. This type of information is being used to guide the design of the layer interfaces in the designs being considered for deployment onsite.

Figure 2.28 compares the spatial distribution of volumetric water content, $\theta$, measured horizontally under the asphalt layer shortly after construction on March 28, 1995, and more recently in April 30, 2004 (see Appendix A, Table A.1, for the data set). After almost 10 years, the spatial trends in $\theta$ remain quite similar with only a small increase in moisture near the edge of the asphalt layer in the winter. Typically, the wetting front migrates about $1 \mathrm{~m}$ under the asphalt before evapotranspiration curtails any further migration. While the extent of the annual migration of the wetting front appears small, underflow remains a major factor for consideration in the design of final covers. Except for a small section near the northeastern corner, the asphalt layer is almost totally curbed to prevent the discharge of water along the edge. These data show that a potential exists for underflow along the edges, although the true extent cannot be determined from the data because of the presence of the curb. The extent, however, could be easily simulated with a calibrated numerical model. 

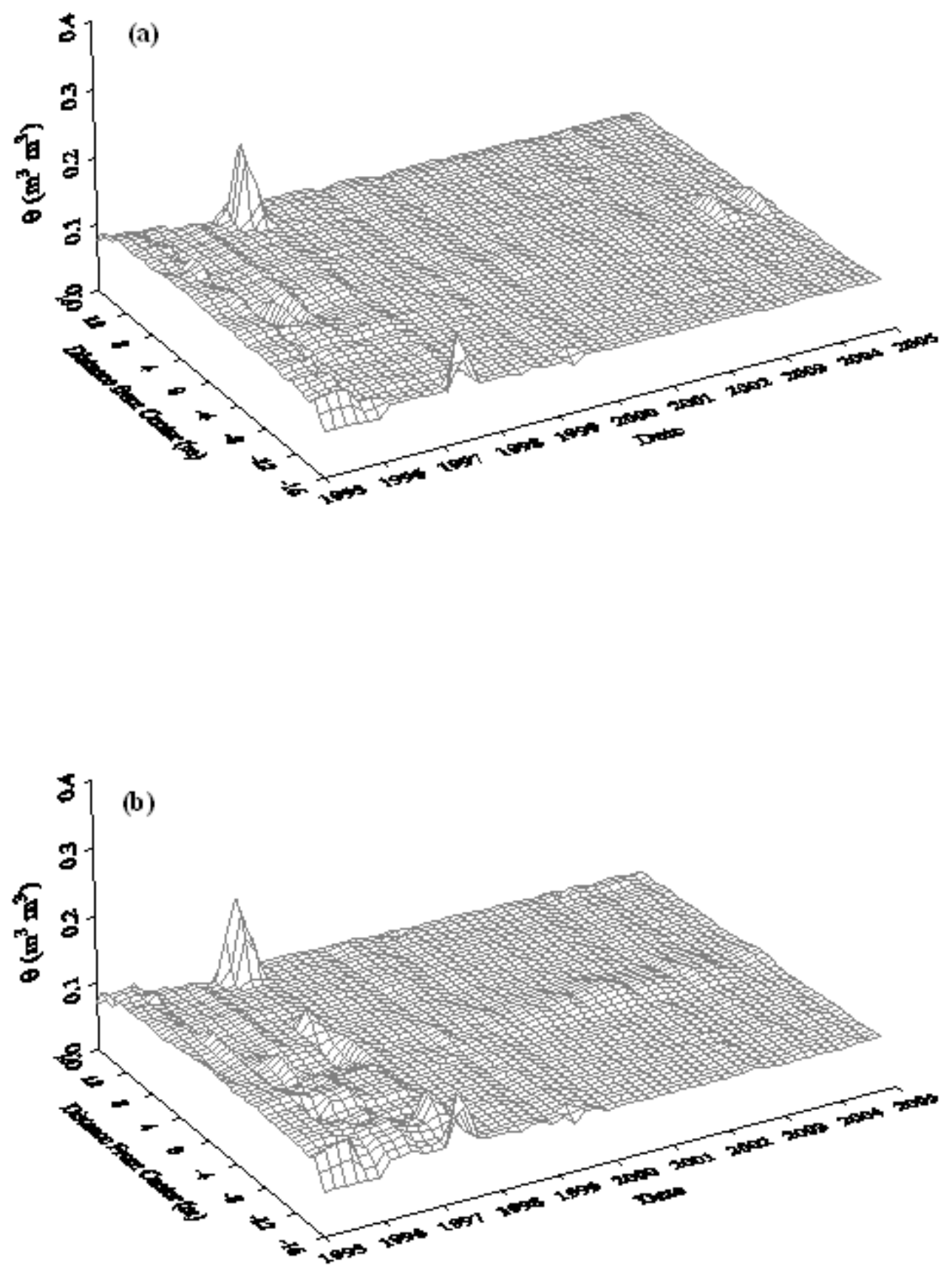

Figure 2.27. Spatiotemporal Variations in Soil-Water Content at the Bottom of the Silt-Loam Layer of the Nonirrigated Treatment of the Barrier: (a) northern end of treatment, tube AA3 + AA7, and (b) southern end of treatment, tube AA4 +AA8 

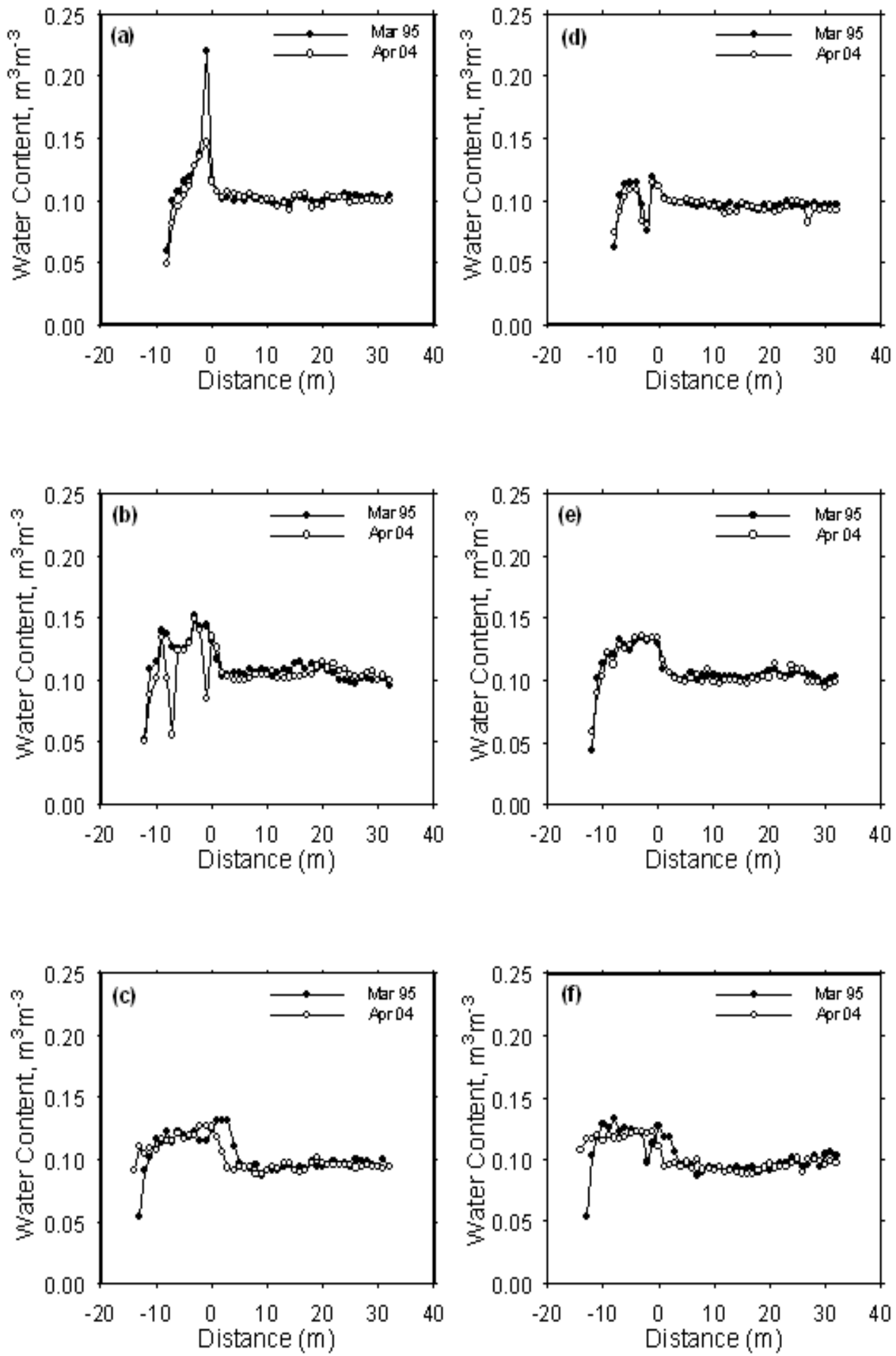

Figure 2.28. Spatial Variation in Soil-Water Content Under the Asphalt Layer (Uncurbed Section) on March 28, 1995, and April 30, 2003: horizontal neutron tubes (a) BA 1 at 1m, (b) BA 3 at $2 \mathrm{~m}$, (c) BA 5 at $3 \mathrm{~m}$, (d) BA 2 at $1 \mathrm{~m}$, (e) BA 4 at $2 \mathrm{~m}$, and (f) BA 6 at $3 \mathrm{~m}$ 


\subsubsection{Evapotranspiration}

The three most important factors controlling the performance of capillary barriers are soil type, climate, and vegetative cover. The contribution of the vegetative cover is through the process of ET, a process that itself is influenced by soil physical characteristics and climatic conditions. Vegetated capillary barriers, such as the prototype Hanford barrier, are designed to maximize ET, thereby limiting the possibility of drainage to the underlying waste zone. Although ET is difficult to measure directly, it can be estimated from a water balance as the difference between water inputs, losses, and storage as described in Equation 2.2. These data were used to solve the water-balance equation and to calculate ET for each soil-covered plot on the two precipitation treatments at the barrier. The calculated ET rates also were compared with those calculated for previous years. The entire water balance for the duration of testing is summarized in Appendix A, Table A.3.

Figure 2.29 compares the average ET rate $\left(\mathrm{mm} \mathrm{d}^{-1}\right)$ for each WY for the north and south plots. These results show initially higher rates on the north section (Figure 2.29a) of the barrier than on the south section (Figure 2.29b). The north plots were irrigated from FY 1995 through FY 1998 as part of the treatability test. The calculated ET rates were not significantly different between plots on the two precipitation treatments. However, the difference between the north and south (irrigated and nonirrigated) sections is quite clear. In the early part of the treatability test through WY 1998, the average ET rate was almost twice as high on the north as on the south. This can be expected because under wetter conditions, plants will transpire more water, within limits. Over time, all plots show a general decline in the average rate of ET, with the decline being more pronounced on the northern plots. The decline may be caused by a combination of factors. First, the reduction observed from WY 1995 to WY 1996 may be related partly to the dramatic change in the plant population at the barrier. In WY 1996, none of the invasive Russian thistle (Salsola kali) was present, compared to WY 1995 when this species dominated the vegetative cover of the barrier. Absence of Russian thistle in later years would have helped to reduce ET rates. Second, it is hypothesized that the native shrubs on the irrigated treatment appear to have experienced some stress from the excess water, which could have impaired their ability to recycle the water.

This hypothesis is supported by the observation that, while the ET rate continued to decline through WY 1997 on the north plot (Figure 2.29a), the ET rate increased slightly on the southern plots (Figure 2.29b). The exception to the general decline is WY 1997 when the southern plots showed a slight increase, perhaps in response to the wetter than normal conditions that occurred that year. WY 1997 was one of the wettest years on record for the barrier. Following the cessation of irrigation at the end of FY 1997, the difference in ET rates on the north and south treatments started to decline. By the end of WY 2000, the difference in average rates was only $0.02 \mathrm{~mm} \mathrm{~d}^{-1}$; by the end of WY 2002, the rates were essentially equal. The convergence of rates suggests that the shrubs on the north section may have finally recovered from the stresses caused by over 3 years of elevated precipitation. All of the plots then showed an increase in ET rate for the first time since WY 1997. In WY 2004, the rate showed a slight decrease, but it was still above the rates observed in WY 1997. These increases are due to the increased availability of water for plant uptake caused by elevated precipitation (Table 2.2). 

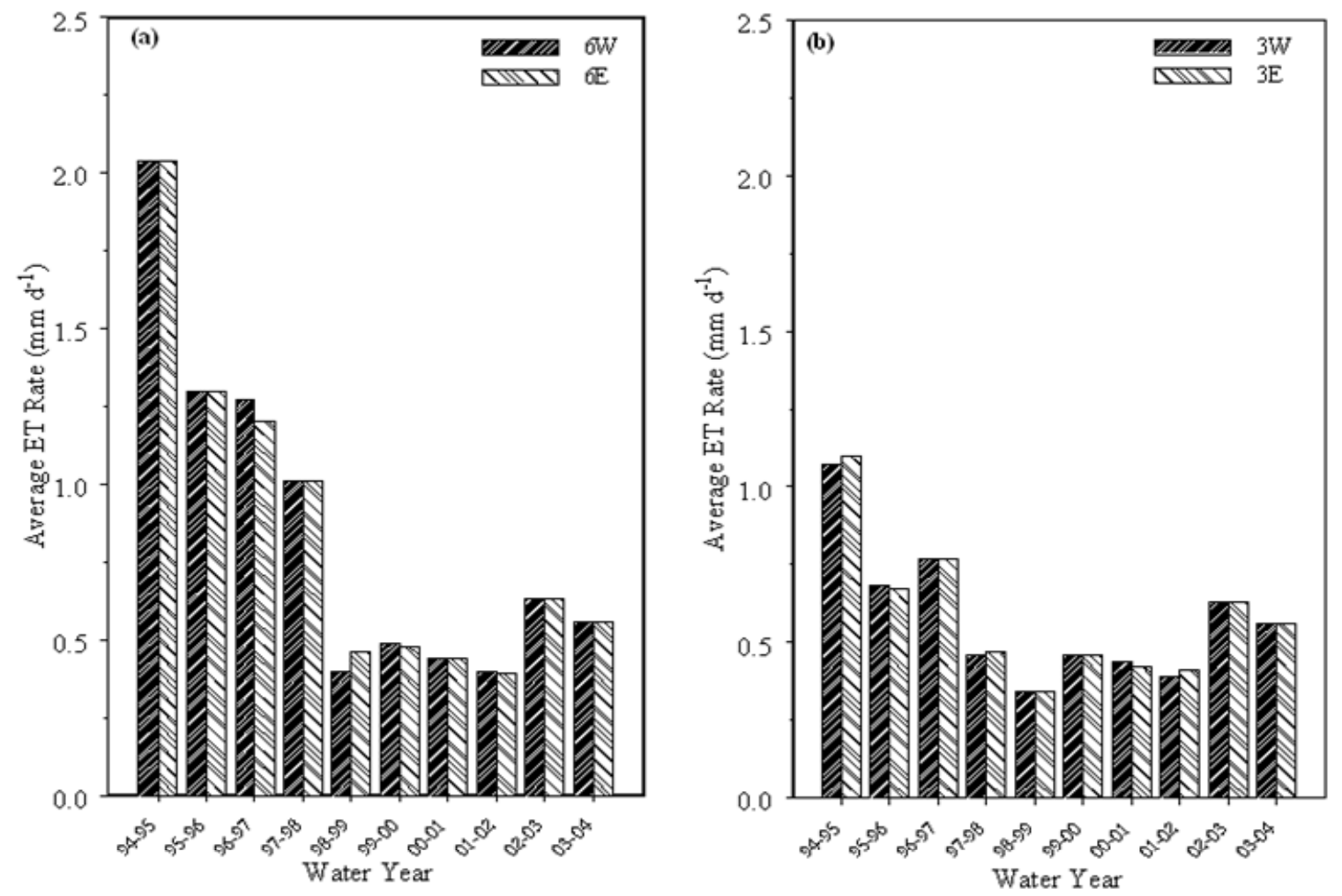

Figure 2.29. Comparison of Average Evapotranspiration Rate at the Prototype Hanford Barrier: (a) North Plots, 6W and 6E, and (b) South Plots, 3W and 3E

Given that the final values of water storage were similar on the north and south plots (Figure 2.6 through Figure 2.10), and no drainage was observed, the apparent difference in ET rate can be attributed solely to increased water uptake. Relative to WY 2003, ET rates showed a decrease of about 20 percent. On both the north and south sides of the barrier, the average ET rate decreased from $0.63 \mathrm{~mm} \mathrm{~d}^{-1}$ in WY 2003 to $0.56 \mathrm{~mm} \mathrm{~d}^{-1}$ in WY 2004. These data show that the native plants can easily adapt to short-term changes in precipitation, adjusting their ET rates to match changes in precipitation and increases in available soil water. Data from the prototype barrier show that the native plant species are capable of routinely recycling precipitation in excess of the long-term average value for the Hanford Site. Although the plants can easily recycle precipitation of about twice the long-time average value for the site, their ability to efficiently recycle precipitation at more than three times the long-term annual average value may be limited to periods of 3 years or less.

\subsection{Recommendations for Fiscal Year 2005}

The elevated winter precipitation and snow accumulation on the barrier highlights the importance of these data for evaluating long-term performance and the importance of the data set for model calibration. One limitation, however, in the current model is the inability to accurately represent the effect of freezing conditions on hydraulic properties and ultimately barrier performance. It is recommended that this deficiency be corrected, and data collected during the winter at the prototype be used for model calibration. 
Although most barrier monitoring systems rely on frequent point measurements of the variables of interest, monitoring near-surface moisture dynamics in multilayered barriers remains one of the few viable options for monitoring field-scale covers. This is because point measurements are of limited use for predicting performance scales much larger than the scale of observation. More desirable technologies for long-term monitoring are those capable of providing spatially continuous measurements of nearsurface moisture conditions over a range of spatial scales. Of the technologies currently available, nonintrusive geophysical methods (surface and airborne) are the most attractive. Unlike many of the traditional monitoring techniques, nonintrusive methods do not impair the integrity of the protective cover, are immune to the effects of sensor degradation, and typically provide measurements at scales ranging from a point to the field scale. Geophysical techniques like electromagnetic induction (EMI) and ground-penetrating radar (GPR) offer significant potential for assessing soil-water content in the near surface and should be evaluated further. With such an understanding gained from these methods, less labor-intensive techniques, such as airborne or satellite-based monitoring systems, could then be evaluated.

For the duration of the monitoring program, small amounts of water have been collected from the soilcovered plots and have been attributed to condensation. However, no attempts have been made to determine the true source of the water. It is recommended that any water accumulated in the vaults connected to the soil-covered plots be collected and analyzed to determine the isotopic ratios. Such an analysis would help identify the source of the water (i.e., drainage or condensation).

\subsection{Summary}

Performance monitoring of the prototype Hanford barrier continued with a scope similar to that following the completion of the treatability test. Increased winter precipitation led to snow accumulation at the barrier. An increase in thunderstorm activity and high-intensity rainfall events led to erosion of the toe of the riprap slope. This erosion appears to have been caused by water running off the BY tank farm adjacent to the barrier. Differences in water storage between the northern and southern sections of the barrier have essentially disappeared. Interplot and intraplot divergence of the lower limit of water storage also have essentially disappeared, particularly in the northeast corner. Differences may have been caused by the irrigation-induced stress on the sagebrush. However, data collected since the completion of the treatability test suggest that the effect of stress may have been temporary. The data reported here support the premise that barrier designs based on the prototype Hanford barrier should easily handle short-term variations in precipitation and changes in water-recycling efficiency. Until this year, precipitation has been around average, and increases in storage have been mostly less than $50 \mathrm{~mm}$ on both sides of the barrier. Annual precipitation in FY 2004 was slightly less than in FY 2003 but was still higher than normal; however, this caused no significant increase in soil-water storage.

Drainage monitoring continued as in previous years, and similar trends have been observed. Results show a complicated relationship between side-slope configuration and precipitation depending on irrigation treatment during the treatability test. On the plots that were irrigated, there is now very little difference between the cumulative drainage from the gravel and riprap side slopes for the duration of monitoring. However, data collected after the end of the treatability test show that the gravel slope exceeds the riprap in drainage. On the nonirrigated side of the barrier, cumulative drainage from the gravel slope exceeds that from the riprap for the entire monitoring period. However, for the period after the treatability test, drainage from the gravel and riprap slopes are essentially equal. The soil plots have 
produced essentially no drainage. The rock slope continues to show a smaller amount of drainage, as discussed in the FY 2001 annual report $^{(\mathrm{a})}$; this discrepancy is most likely caused by advective drying. Horizontal neutron-probe measurements above and below the asphalt shows no evidence of deep percolation of water. Lateral movement of water under the asphalt layer was quite limited. Waterbalance calculations show an increase in evapotranspiration relative to the period immediately after the treatability test because of increases in precipitation and available soil water as well as plant biomass. Although total precipitation in FY 2003 and FY 2004 were quite similar, there was a 20-percent reduction in evapotranspiration rates, likely caused by a change in the seasonal distribution of the precipitation.

(a) CCN 100381, 2002, "200-BP-1 Prototype Hanford Barrier Annual Monitoring Report for FY 2001," (letter to B. L. Foley, U.S. Department of Energy, Richland Operations Office), from M. J. Graham, Bechtel Hanford, Inc., Richland, Washington, June 18. 


\subsection{Barrier Stability}

The objective of this task was to monitor the stability of the barrier by measuring elevation changes in the subgrade below the asphalt layer and the surface soil layer and by measuring displacements in the riprap side slope. The scope of the effort involved taking elevation surveys at the surface 3-m by 3-m grid stakes (338 stakes total) and two settlement markers as well as displacement (vertical and horizontal) surveys of the 15 creep gauges. Survey data are provided in Tables A.3 through A.5. Stability surveys were conducted in December 1994, July 1995, September 1995, January 1996, September 1996, January 1997, September 1997, July 1999, August 2000, August 2001, August 2002, and most recently in August 2003 (DOE-RL 1999; Fluor Hanford 2003). ${ }^{(\mathrm{a}, \mathrm{b}, \mathrm{c})}$

\subsection{Methodology}

The surface of the barrier was demarcated with a coordinate system established by a 3-m by 3-m grid as shown in Figure 2.1. Each interior grid point is marked with a wooden survey stake, numbered to identify the grid coordinate. Elevation measurements were taken at the location of each stake on the 3-m by 3-m grid using an electronic distance measurement (EDM) system. To enable monitoring of the order and magnitude of settlement in the subgrade below the asphalt layer (i.e., beneath the barrier) and within the barrier, two settlement markers have been installed. One marker is located at the northern end of the barrier (DSG1), near the crown, and the other marker is located about $14 \mathrm{~m}$ to the east of the first marker (DSG2). Movement of the asphalt surface is an indicator of subgrade settlement and is quantified by measuring the change in the elevation of the top of the settlement marker rods.

To enable monitoring of the riprap side-slope stability, creep gauges were installed at 13 locations (CG1 through CG13b) in the eastern slope (Figure 2.1). At 11 of the 13 locations, a gauge is located at the mid-slope position on the riprap. At the other two locations, two gauges are installed (CG10a and CG10b; CG13a and CG13b), at the upper and a lower slope position, respectively. Additional descriptions of the monitoring stations can be found in DOE-RL (1999). Since installation, the additional creep gauges have been surveyed roughly on a quarterly basis except for the last year in which there was a single survey. Previous quarterly surveys were in 2001, 2002, and 2003. From the start of monitoring, elevation measurements were made by EDM using a laser theodolite system. Surface elevations were made on the 3-m by 3-m grid, including the settlement gauges at least once per year. In FY 2004, for the first time, the EDM technique was replaced due to an equipment malfunction. The EDM system has fallen out of calibration and cannot be serviced.

(a) CCN 073428, 1999, “200-BP-1 Prototype Hanford Barrier Annual Monitoring Report for FY 1999," (letter to B. L. Foley, U.S. Department of Energy, Richland Operations Office), from M. J. Graham, Bechtel Hanford, Inc., Richland, Washington, September 30.

(b) CCN 083132, 2000, “200-BP-1 Prototype Hanford Barrier Annual Monitoring Report for Fiscal Year 2000," (letter to B. L. Foley, U.S. Department of Energy, Richland Operations Office), from M. J. Graham, Bechtel Hanford, Inc., Richland, Washington, October 19.

(c) CCN 100381, 2002, "200-BP-1 Prototype Hanford Barrier Annual Monitoring Report for FY 2001," (letter to B. L. Foley, U.S. Department of Energy, Richland Operations Office), from M. J. Graham, Bechtel Hanford, Inc., Richland, Washington, June 18. 
In FY 2004, we evaluated two technologies for extracting high-resolution topographic data for the prototype barrier. The EDM survey was replaced with a real-time-kinematic (RTK) global positioning system survey and digital photogrammetry using aerial photographs of the barrier. The GPS survey was conducted on May 10, 2004, while the aerial photographs were taken on August 17, 2004.

\subsubsection{DEM Generation from Aerial Photogrammetry}

Aerial photography (AP) has long been used as an efficient method of generating topographic maps and, more recently, digital elevation models for geomorphic applications. Aerial photographs are among the most important, widely available, and commonly used kinds of remotely sensed images. They are used for all manner of land resources, cartographic, and appraisal surveys in the public and private sectors. They are often employed as "base maps" upon which thematic data are portrayed. Aerial photogrammetry is the science or art of obtaining reliable measurements (distance, angle, area, elevation) from aerial photography. Automated digital photogrammetry is a relatively new technique with much potential, but routine use has been limited by the need for expensive third-party software. During the last year, automated digital photogrammetry was applied to aerial photographs of the prototype barrier to examine the feasibility of using this technique for monitoring changes in elevation. A computer program developed by Dr. G. Seedahmed at PNNL was used to convert the aerial photographs into a digital elevation model. The overall process can be summarized in four steps as follows:

1. Digital aerial photographs of the prototype barrier were obtained from at least two distinct viewpoints using a predetermined flight plan.

2. The coordinates and elevations of a predetermined number of control or feature points were determined.

3. In each photograph, the feature points were identified, the pixel locations extracted, and the information used to form a measurement matrix.

4. From the corresponding feature points, the unknown camera positions and surface topography are simultaneously estimated by inverting the measurement matrix.

The process of digital elevation model (DEM) generation from aerial photographs requires the availability of a few ground-control points and the measurement of similar features (points) in two images or more. Figure 3.1 shows an example of two overlapping images used to generate the DEM in this study.
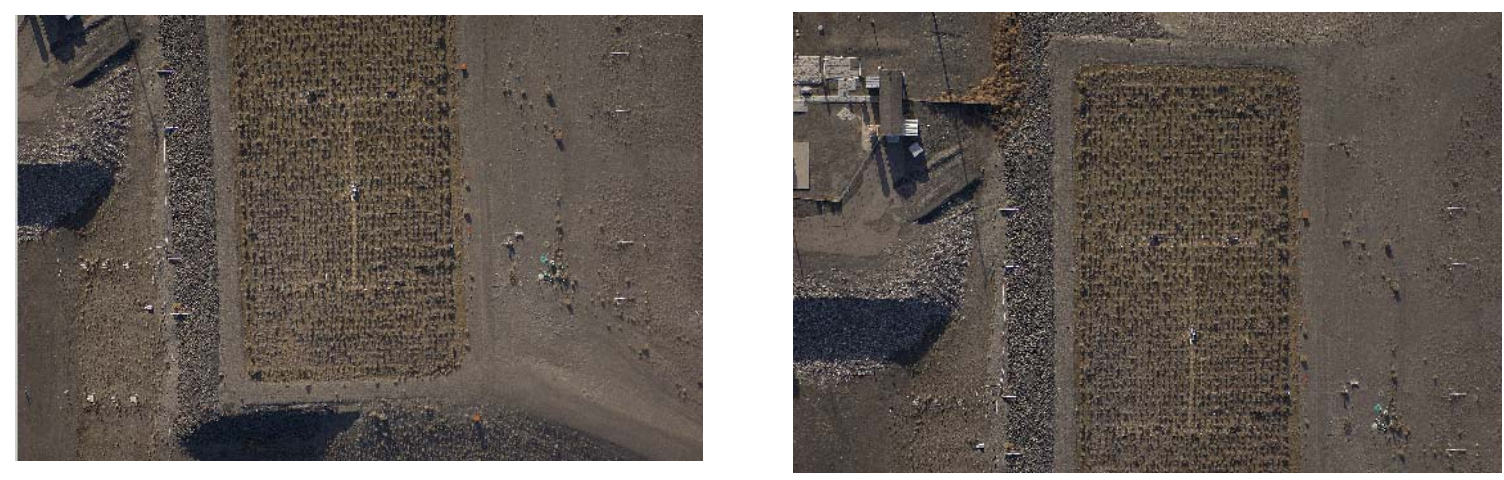

Figure 3.1. Example of two Overlapping Images used to Extract Control Point of Generation of the Digital Elevation Model 
To this end, four ground-control points were measured on the barrier to establish the relationship between the two images and the ground (Figure 3.2). The coordinates and elevation of the ground-control points were determined from an earlier survey. In specific terms, this relationship led to the determination of the transformation parameters between the images and the ground. A semi-automated procedure was developed to measure (typically called image matching) the similar conjugate points. This procedure considers prior knowledge about the area of interest and its average elevation (Figure 3.3).

In this study, the area of interest was limited to the silt-loam surface of the barrier as depicted by the yellow rectangle in Figure 3.3.
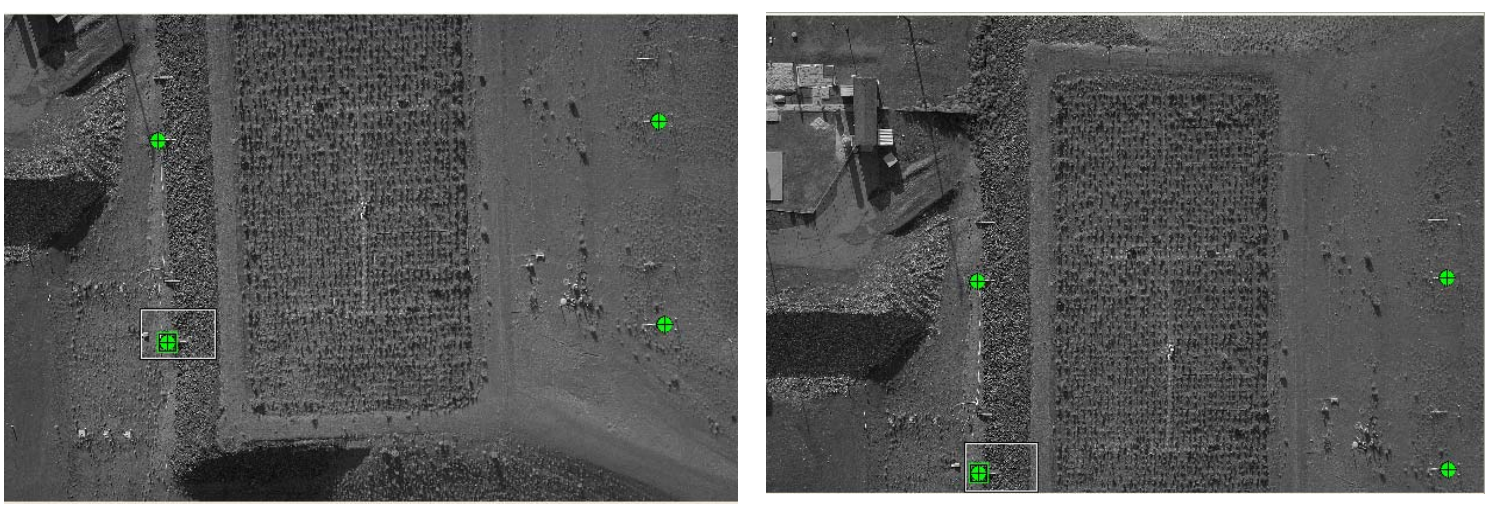

Figure 3.2. Locations of the Ground Control Points (indicated by the green color)

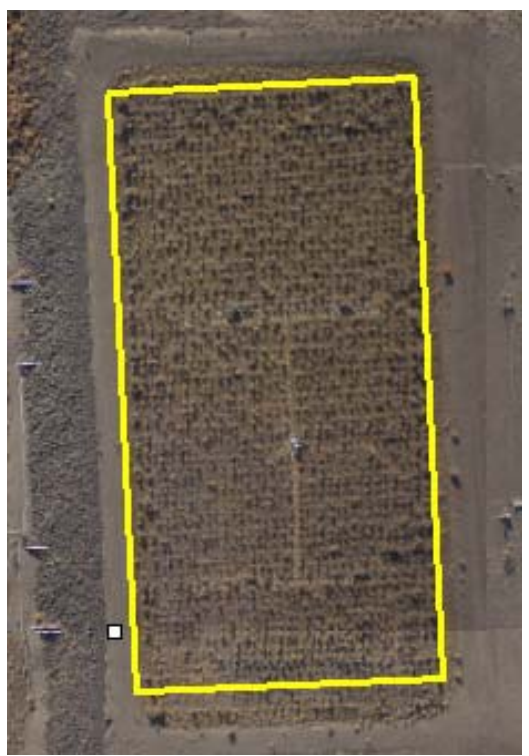

Figure 3.3. Outline of Sampling Area used for Calculation of Elevation. 
This technique requires the selection of corresponding points (on the order of 100) from two or more photographs, from which the camera positions and surface topography are simultaneously estimated. Within the area of interest, the algorithm was used to determine the corresponding 2D coordinates from the two images on a spatial resolution chosen by the user (Figure 3.4). Using the corresponding 2D points from the two images, the goal is to determine the $3 \mathrm{D}$ coordinates of each point. The final step involves factoring the measurement matrix to recover the surface topography from the aerial photographs.
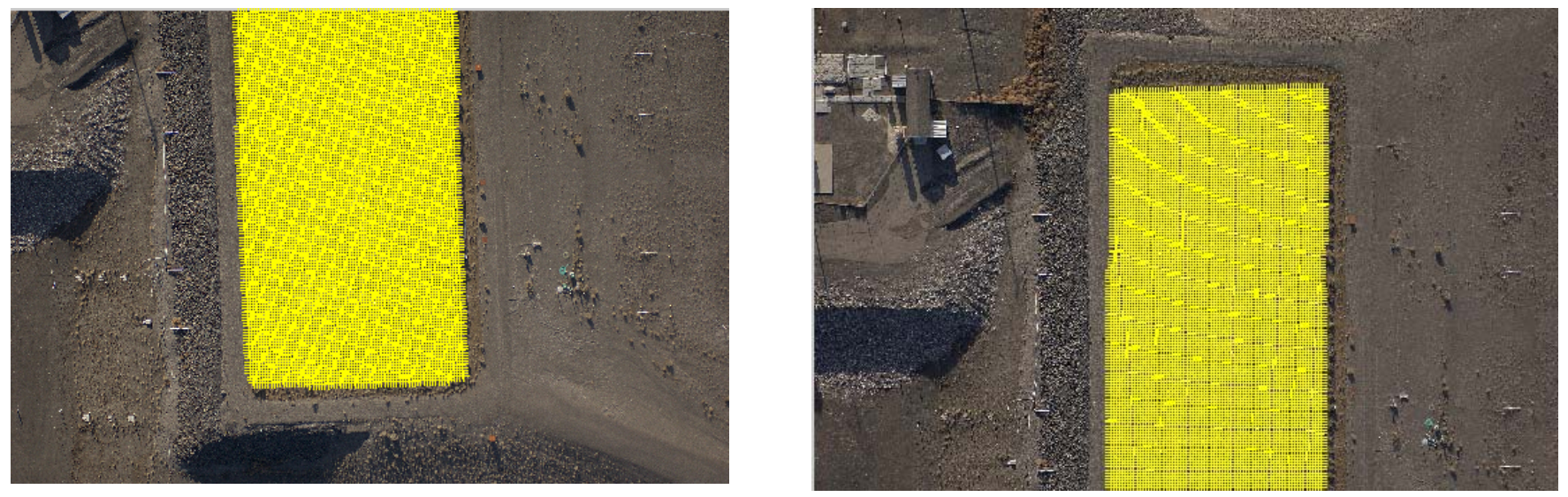

Figure 3.4. Selection of Corresponding Points

With this method, the generated DEM represents the actual landscape. Furthermore, resolution of the DEM depends only on how many corresponding points are selected from the photographs by the user. The present algorithms select points automatically on a Cartesian grid provided by the user.

\subsubsection{DEM Generation from Global Positioning System Surveys}

The GPS is a worldwide radio-navigation system formed from a constellation of 24 satellites and their ground stations. In the typical GPS survey, the satellites are used as reference points to calculate positions accurate to within meters. With the more advanced forms of GPS, measurements can be made with sub-centimeter precision. The basis of GPS is to use satellites in space as reference points for locations here on earth. Therefore, by very accurately measuring our distance from three satellites, we can "triangulate" our position anywhere on earth. A GPS survey can be summarized in four basic steps.

1. Triangulation - to triangulate a GPS receiver measures distance using the travel time of radio signals.

2. Travel Time Measurement—GPS needs very accurate timing, which it achieves with some tricks.

3. Locate Satellites - along with distance, the location of the satellites in space must be known accurately.

4. Travel Time Correction - a correction for any delays the signal experiences as it travels through the atmosphere back to the receiver.

A complete survey of the prototype barrier was performed using GPS. The GPS surveying equipment consisted of a Trimble RTK 5700 base station with a RTK 5800 rover (Figure 3.5) and a Trimmark 3 Base Station Radio with a 6-ft whip antenna (Figure 3.6), all manufactured by Trimble Navigation Limited (Sunnyvale, CA). 


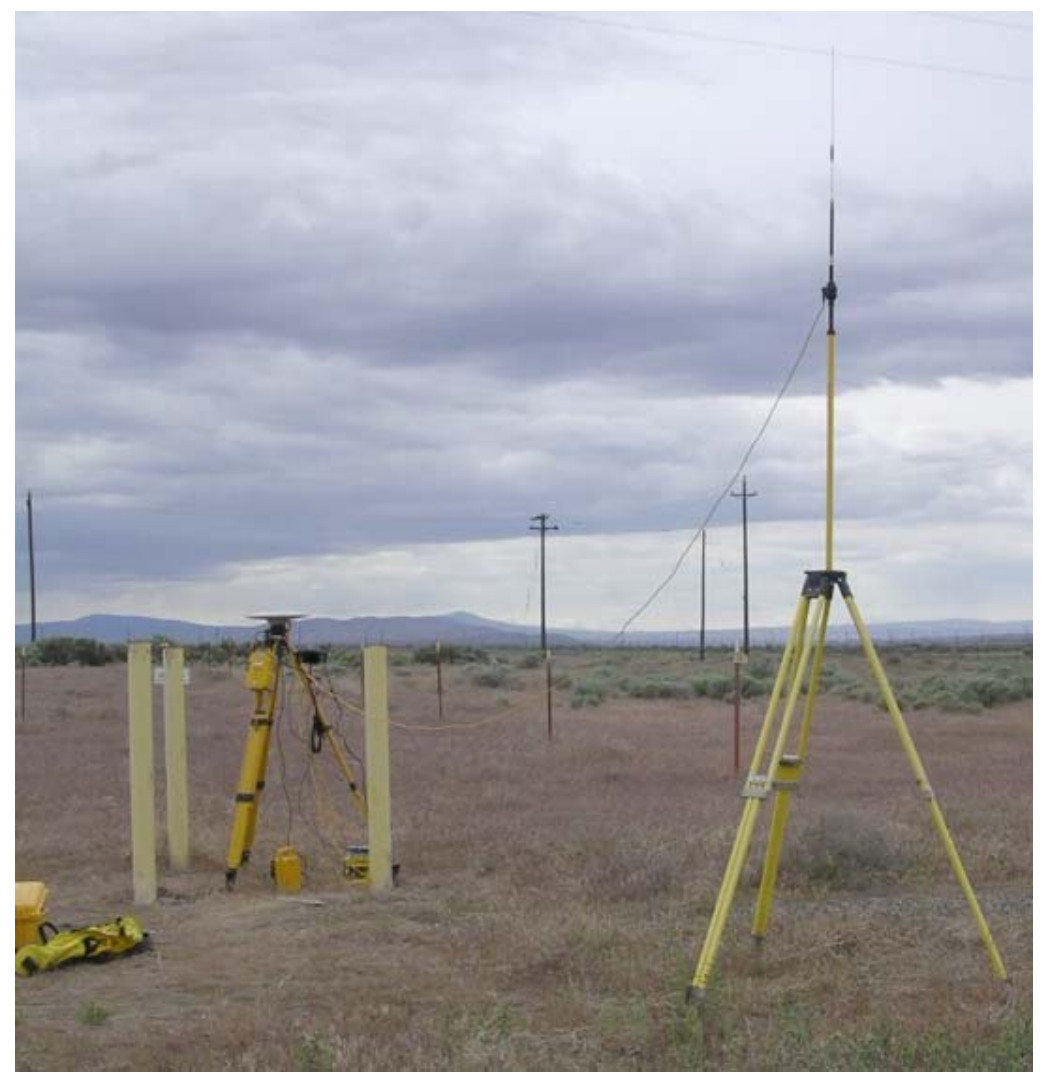

Figure 3.5. Real-Time Kinematic GPS Surveying System with a 5700 Receiver and Trimmark 3 Base Station Radio with Whip Atenna

For the survey, the base station was placed over a known point, this being benchmark 2E-122. Using its known position, the base station continually determines what the signal travel times from the GPS satellites to the base station should be and then compares this to the actual travel time. Using this information, the base station then calculates a satellite-specific correction factor, which it then broadcasts to the rover unit using the base-station radio. The rover unit uses the correction factors for dynamic corrections of the rover's GPS measurements. This process allows the accuracy of the GPS system to be improved from meters to less than a centimeter.

At each survey point, a 10-second reading was taken with the rover unit. From investigations of the optimum measurement times, it was determined that a 10 -second reading provided the most accuracy with no appreciable accuracy gain after 10 seconds. All data points were stored in the rover unit and later downloaded to a PC. Data were processed using Trimble Geomatics post-analysis software and used to generate the DEM. Surveying the entire barrier, including the surface, creep gauges, and settlement gauges took about 4 hours. 


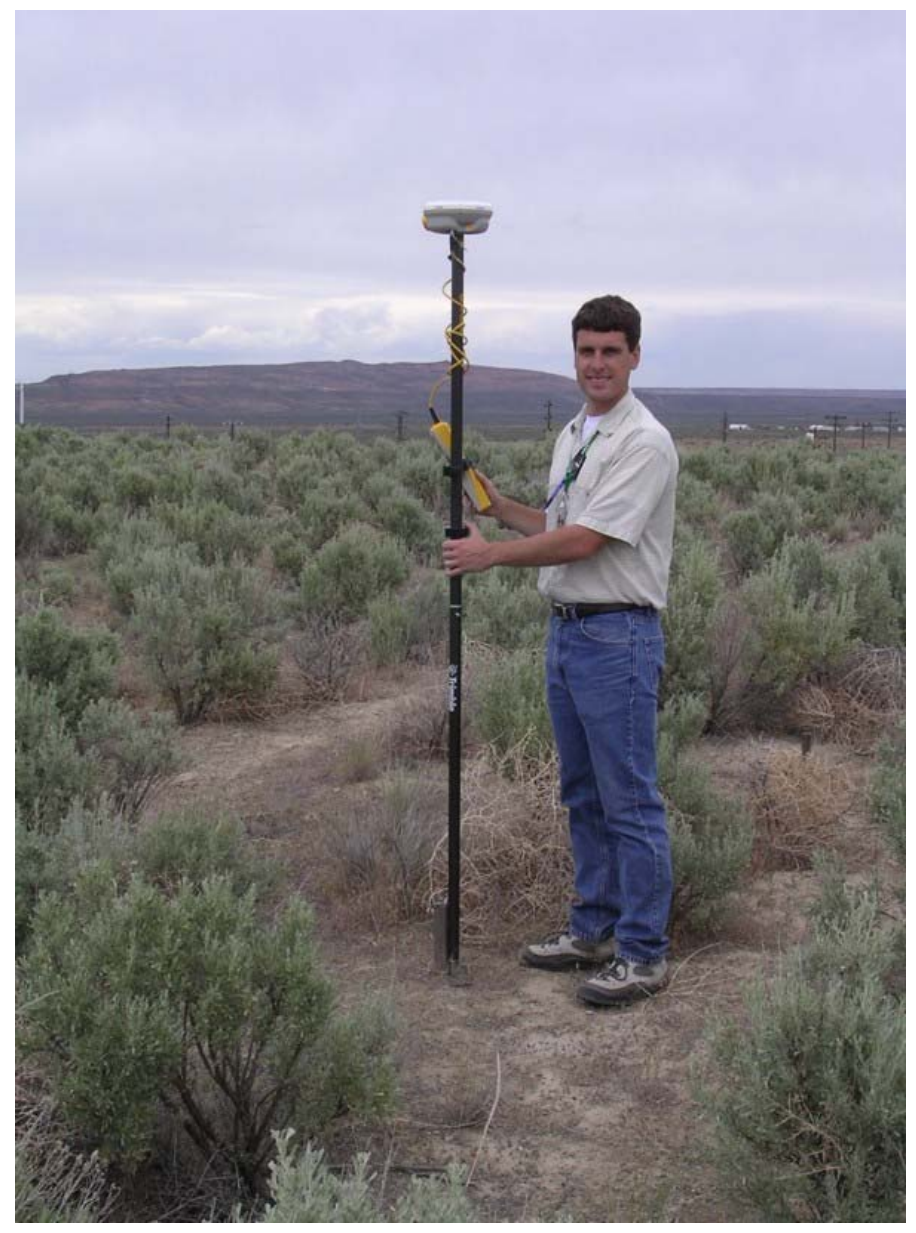

\section{Figure 3.6. Real-Time Kinematic 5800 Rover Unit at the Prototype Barrier (Jason Keller supports the unit)}

\subsection{Results}

\subsubsection{Settlement Gauges}

Table 3.1 summarizes the settlement gauge elevation and changes since December 1994 when the first survey was completed. Since the last survey recorded in the treatability test report, the two settlement gauges (Figure 2.1) have shown very slight changes in elevation. These changes were typically within the range of measurement error of the EDM. The FY 2004 survey was conducted using GPS, and the results show a departure from the relatively small changes. The two gauges show a mean increase of $0.077 \mathrm{~m}$ (Figure 3.7). This apparent increase, which is not considered real, may be a reflection of the error in elevation measurements with GPS. Conventional GPS typically measures elevation to within $1 \mathrm{~m}$. The current RTK system, which uses travel-time corrections, can measure elevation within $5 \mathrm{~mm}+2 \mathrm{ppm}$. Elevation measurements on the settlement gauges were made with a mean precision of $0.00983 \mathrm{~m}$. With the expected change to GPS or aerial photogrammetry for future surveys, the results from FY 2004 will be used as a baseline, and future changes will be calculated from this point. No significant changes are expected. 
Table 3.1. Elevations and Elevation Changes of Settlement Gauges from December 1994

\begin{tabular}{|l|c|c|c|c||}
\hline \multicolumn{1}{|c|}{ Date } & DSG1 (W) & $\begin{array}{c}\text { Elevation } \\
\text { Change (m) }\end{array}$ & DSG2 (E) & $\begin{array}{c}\text { Elevation } \\
\text { Change (m) }\end{array}$ \\
\hline Dec 1994 & 201.954 & 0.000 & 201.687 & 0.000 \\
\hline Sep 1995 & 201.958 & 0.004 & 201.690 & 0.003 \\
\hline Jan 1996 & 201.967 & 0.013 & 201.698 & 0.011 \\
\hline Sep 1996 & 201.965 & 0.011 & 201.698 & 0.011 \\
\hline Jan 1997 & 201.961 & 0.007 & 201.686 & -0.001 \\
\hline Sep 1997 & 201.963 & 0.009 & 201.698 & 0.011 \\
\hline Jul 1999 & 201.950 & -0.004 & 201.683 & -0.004 \\
\hline Aug 2000 & 201.951 & -0.003 & 201.658 & -0.029 \\
\hline Aug 2001 & 201.947 & -0.007 & 201.675 & -0.012 \\
\hline Aug 2002 & 201.948 & -0.006 & 201.683 & -0.004 \\
\hline Aug 2003 & 201.953 & -0.001 & 201.687 & 0.000 \\
\hline May 2004 & 202.032 & 0.078 & 201.763 & 0.076 \\
\hline \hline
\end{tabular}

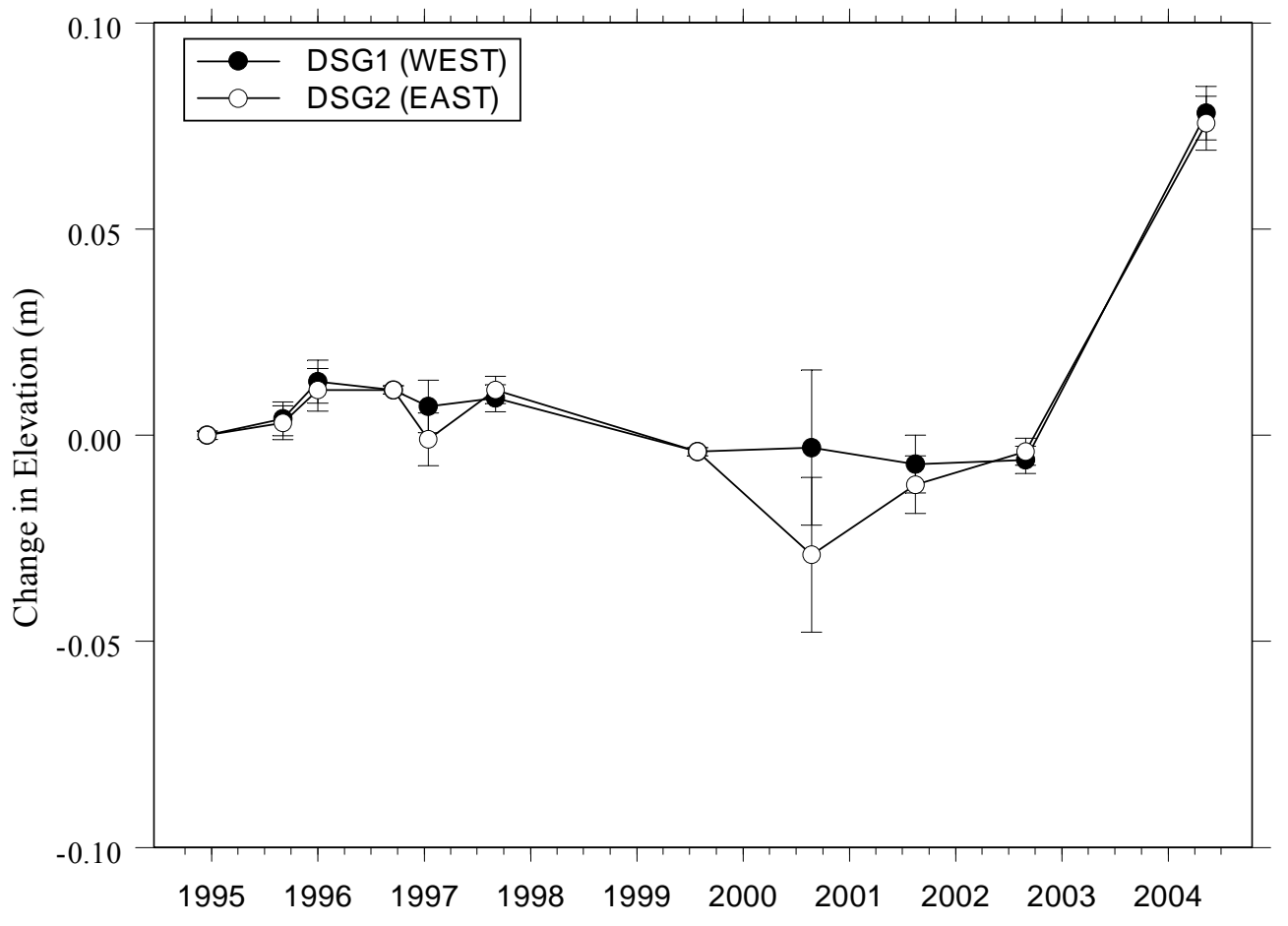

Figure 3.7. Summary of Changes in Settlement Gauge Elevation Between November 1, 1994, and May 10, 2004. (Error bars represent the total measurement error; DSG2 is located $14 \mathrm{~m}$ east of DSG1.) 


\subsubsection{Creep Gauge Movement}

During the treatability test, creep gauge data suggested a small degree of outward movement of the riprap side slope on the east side of the barrier. Although not all of the observed displacements were statistically significant, additional monitoring was recommended to better assess changes in displacement rates over time. A combination of creep gauge and surface elevation measurements prompted a decision to increase the level of monitoring at the southeast corner of the cover. In FY 2000, three additional creep gauges (CG12, CG13a, and CG13b) were installed at the southeast corner in the riprap side slope as shown in Figure 2.1. Starting in February 2000, the new creep gauges were monitored quarterly. The other 12 creep gauges continue to be monitored annually. In FY 2004, only one survey (May 10, 2004, by GPS) was conducted on the creep gauges.

Figure 3.8 shows the net horizontal displacement and direction between the first survey (December 1994 for gauges 1 through 11 and February 2000 for gauges 12 through 13b) and the most recent GPS survey. The pattern is not significantly different than that observed in FY 2003. As with the FY 2003 results, most of this movement appears to be in a north or northeasterly direction. The range of motion is confined mostly between 0.02 and $0.04 \mathrm{~m}$ with CG1 showing a slightly larger range. The largest net change was observed on CG1, which has moved about $5 \mathrm{~cm}$, followed by CG4, and CG10b, each moving just over $3 \mathrm{~cm}$ in a generally north-easterly direction. These results are consistent with those observed in the past. With the high precision of horizontal measurements obtained with the GPS ( $5 \mathrm{~mm}+0.5 \mathrm{ppm})$, the error in these measurements is actually less than that obtained with the EDM.

Figure 3.9 through Figure 3.12 show temporal plots of gauge location for the duration of monitoring. The polar plots are used to quantify the magnitude and direction of the horizontal component to the displacement vector. However, the plots provide no information about vertical changes. None of these data show obvious trends, and range of motion is typically between to 0.02 and $0.04 \mathrm{~m}$ with no preferred direction, except for CG1. Movement of CG1 appears to be most easterly with a range of about $0.06 \mathrm{~m}$. Close observation over the years has shown evidence of slope movement.

Figure 3.13 through Figure 3.16 show the changes in elevation of the 15 creep gauges over the monitoring period. Up until FY 2004, all of the gauges show small changes $(\leq 2 \mathrm{~cm})$ in elevation with no obvious trends. In fact, most changes to appear quite random, falling within the measurement error of the surveying systems. The FY 2004 measurement shows an increase of about $0.07 \mathrm{~m}$ relative to 1994. As with the settlement gauges, we attribute this to the change in surveying systems and will use this point as the baseline for future GPS measurements. 


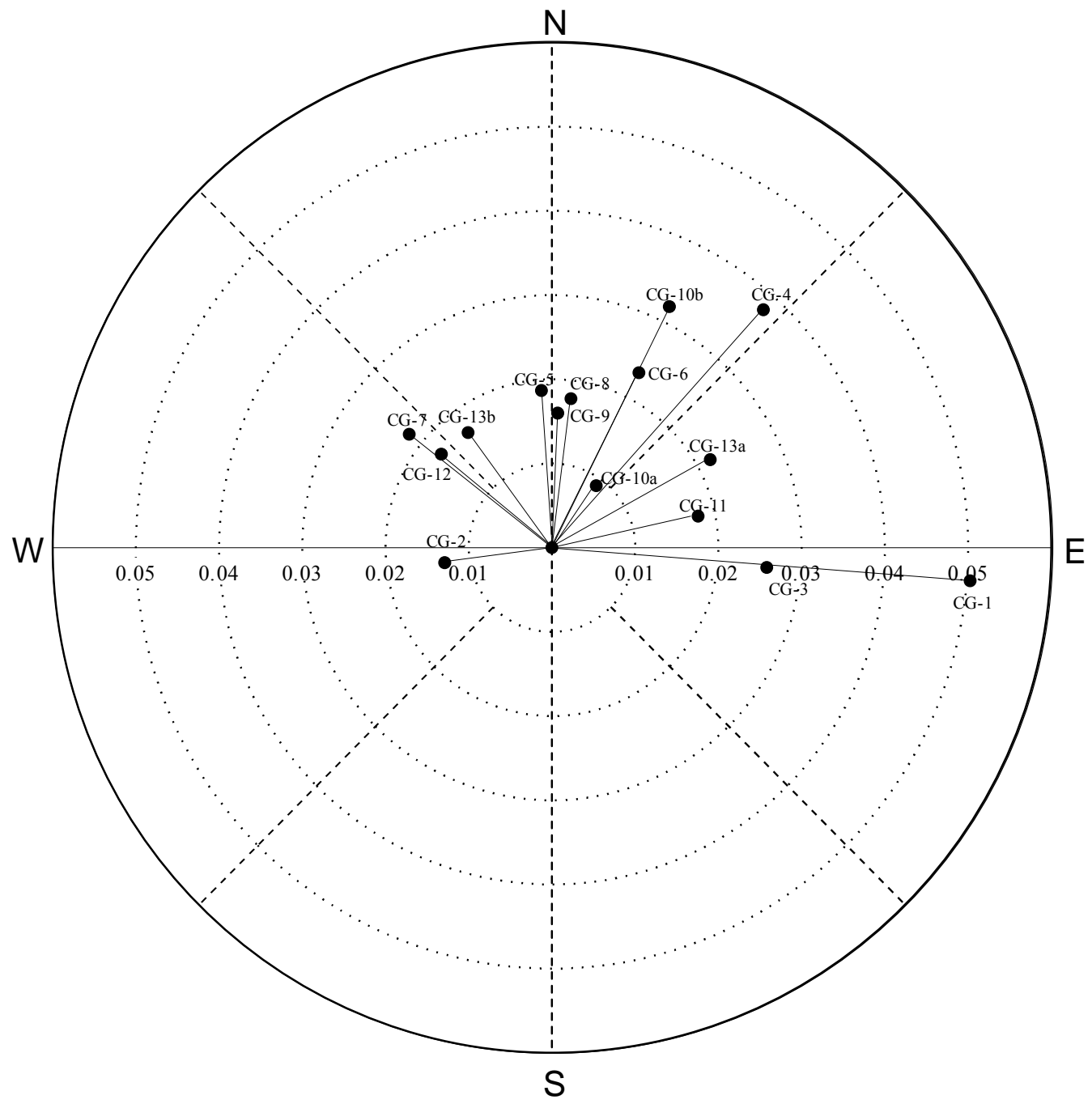

Figure 3.8. Net Creep Gauge Movement Between December 1994 and May 2004. (Elevation measured by EDM; the resultant [horizontal component] is in meters). 
(a)

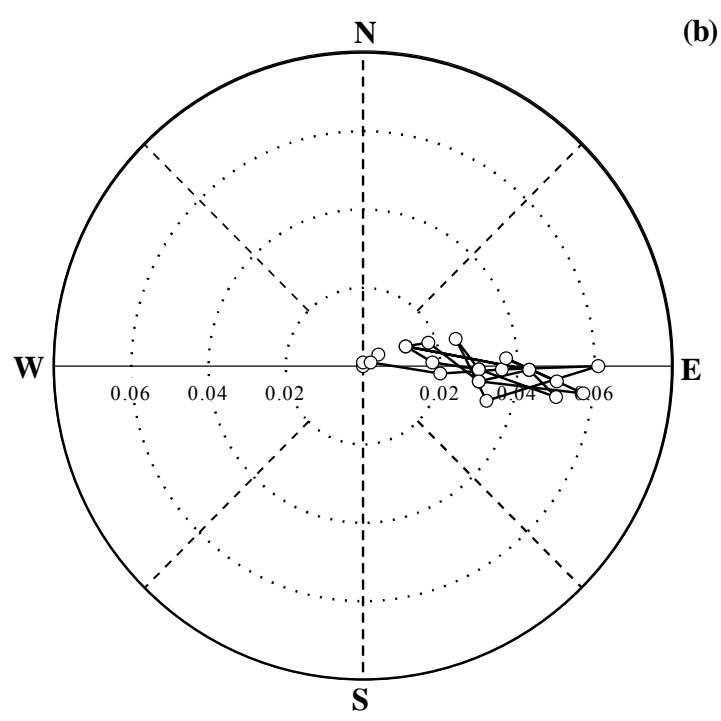

(c)

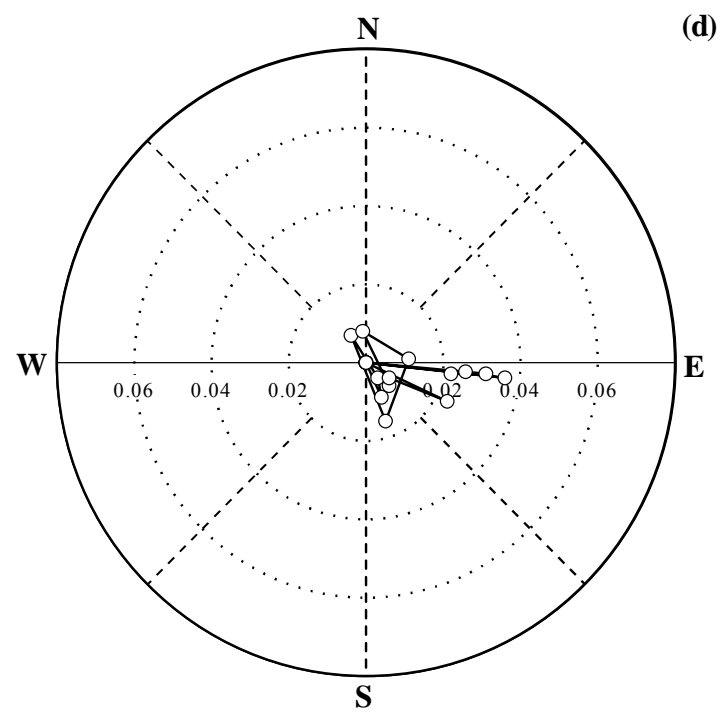

(b)

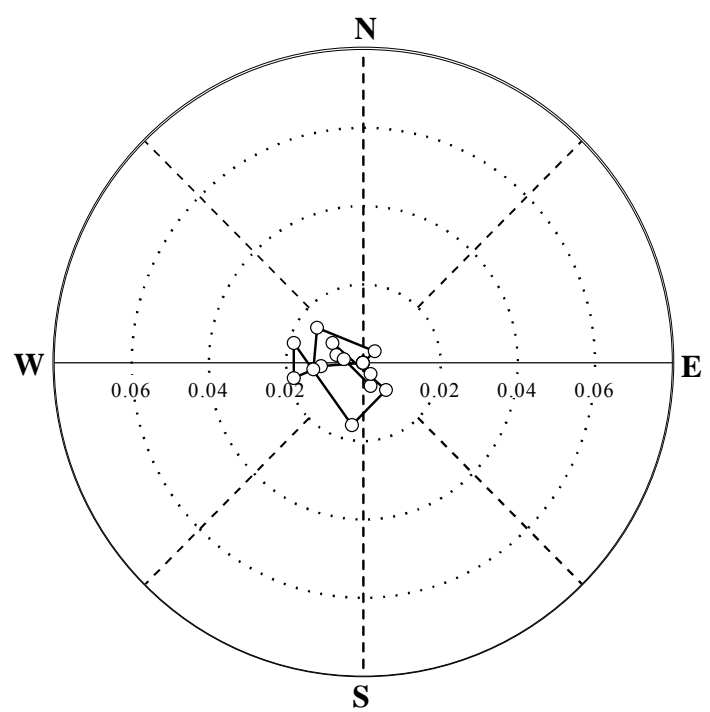

(d)

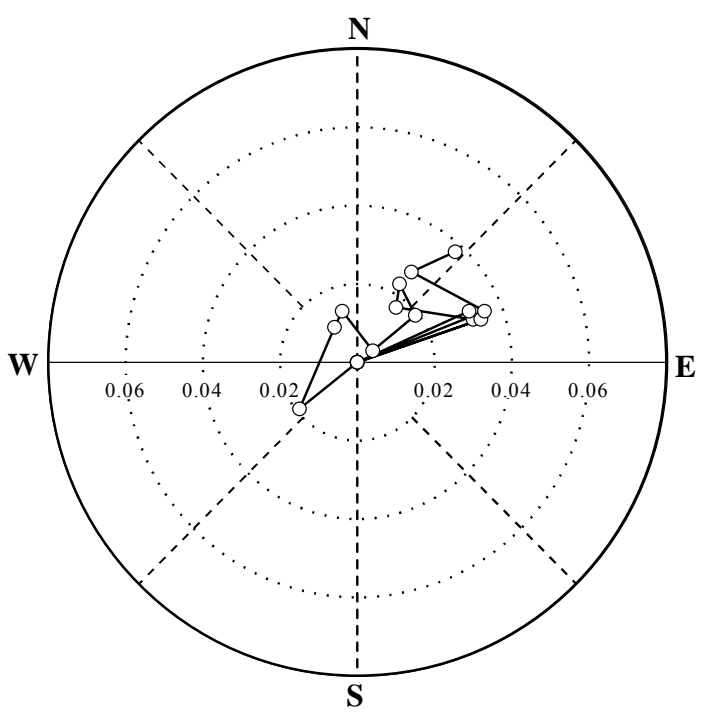

Figure 3.9. Net Creep Gauge Movement Between December 1994 and May 2004: (a) CG1, (b) CG2, (c) CG3, and (d) CG4. (Elevation measured by EDM; the resultant [horizontal component] is in meters.) 
(a)

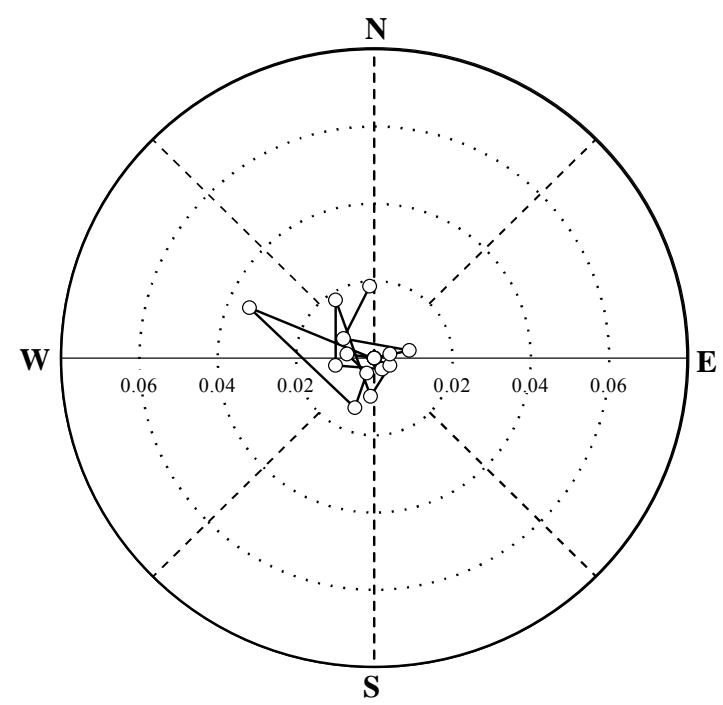

(c)

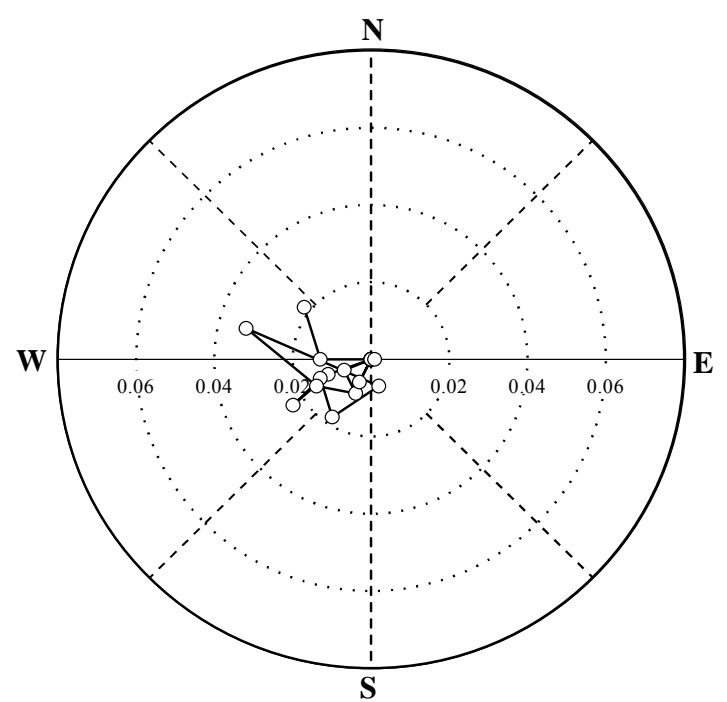

(b)

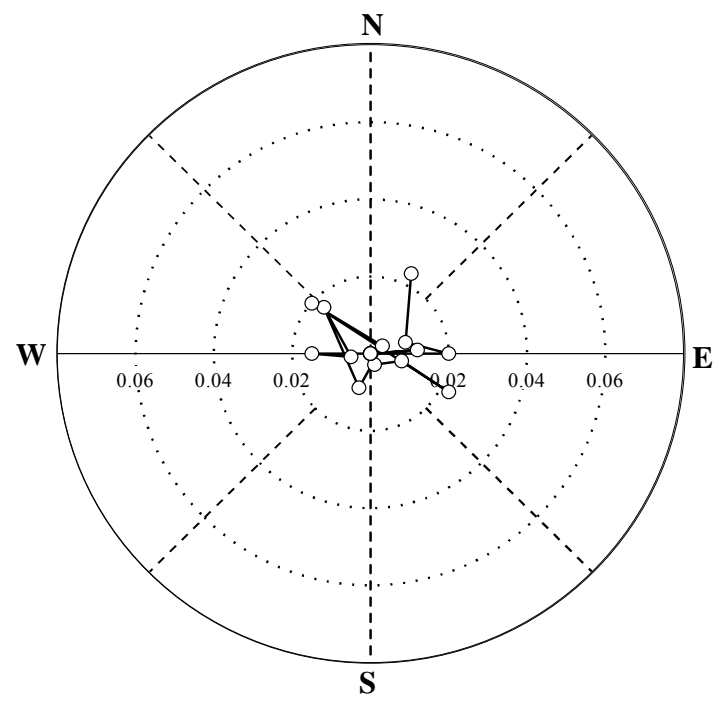

(d)

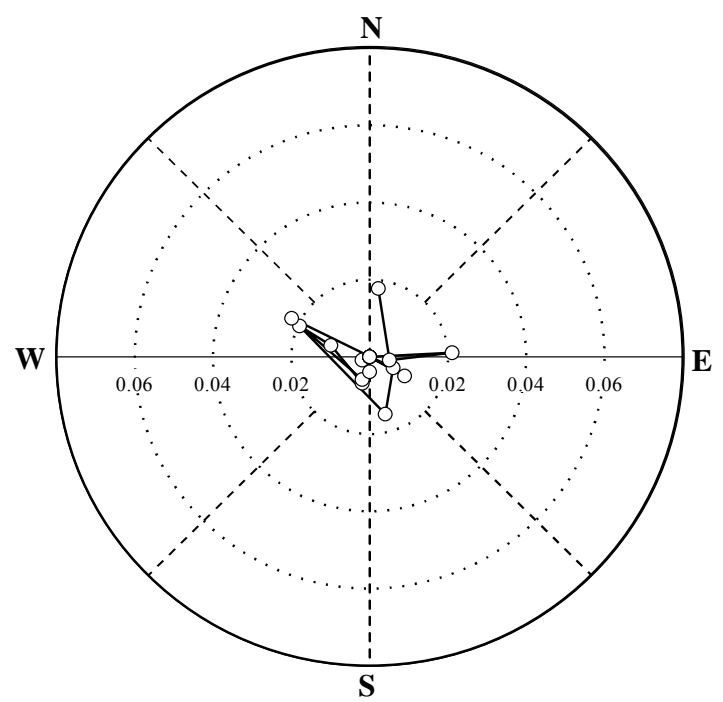

Figure 3.10. Net Creep Gauge Movement Between December 1994 and May 2004: (a) CG5, (b) CG6, (c) CG7, and (d) CG8. (Elevation measured by EDM; the resultant [horizontal component] is in meters.) 
(a)

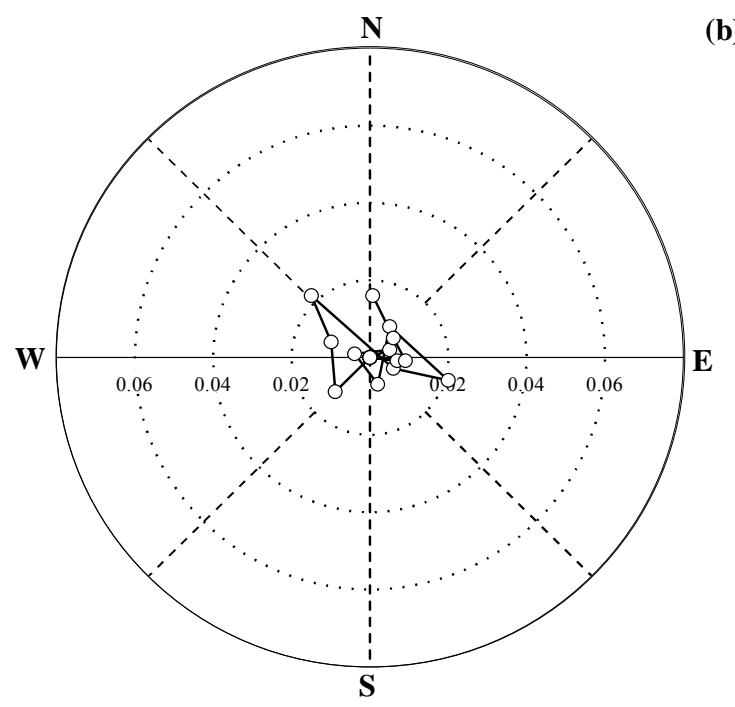

(c)

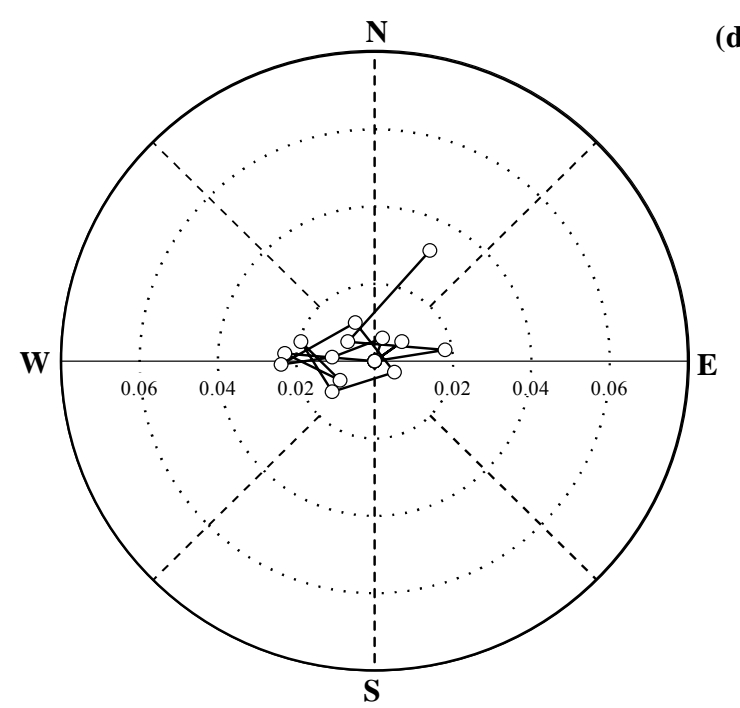

(b)

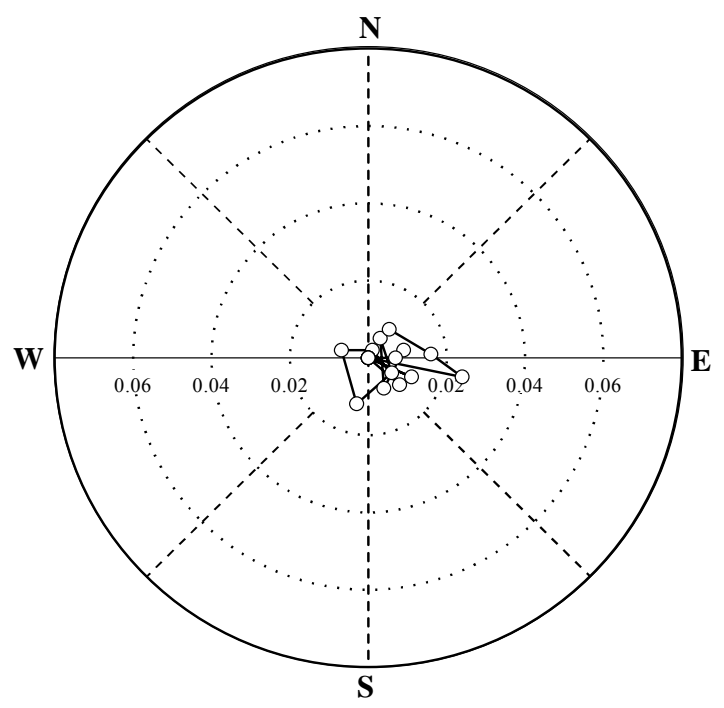

(d)

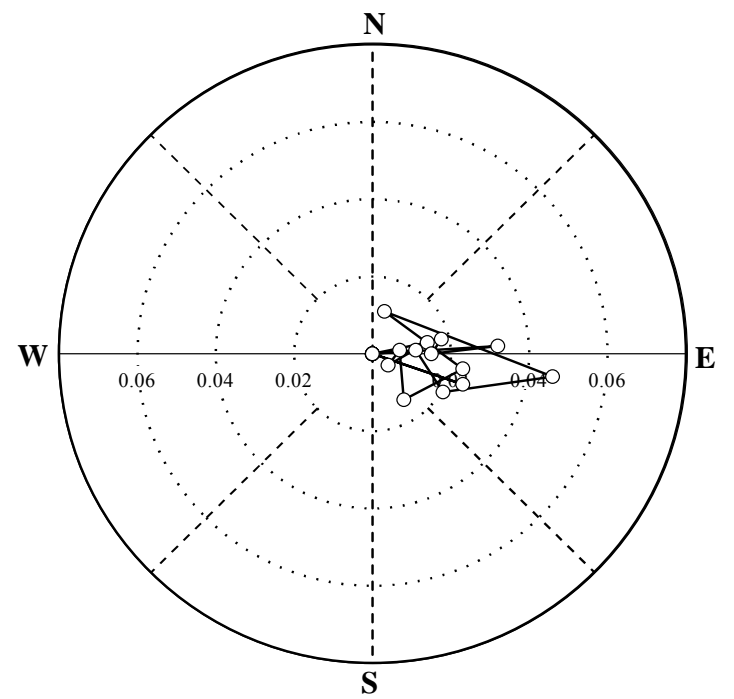

Figure 3.11. Net Creep Gauge Movement Between December 2001 and May 2004: (a) CG9, (b) CG10a, (c) CG10b, and (d) CG11. (Elevation measured by EDM; the resultant [horizontal component] is in meters.) 
(a)

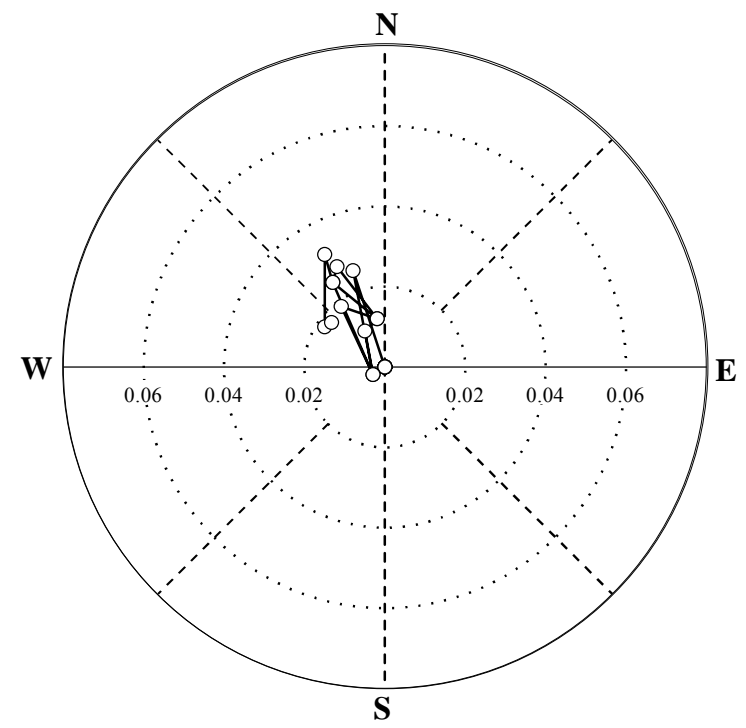

(b)

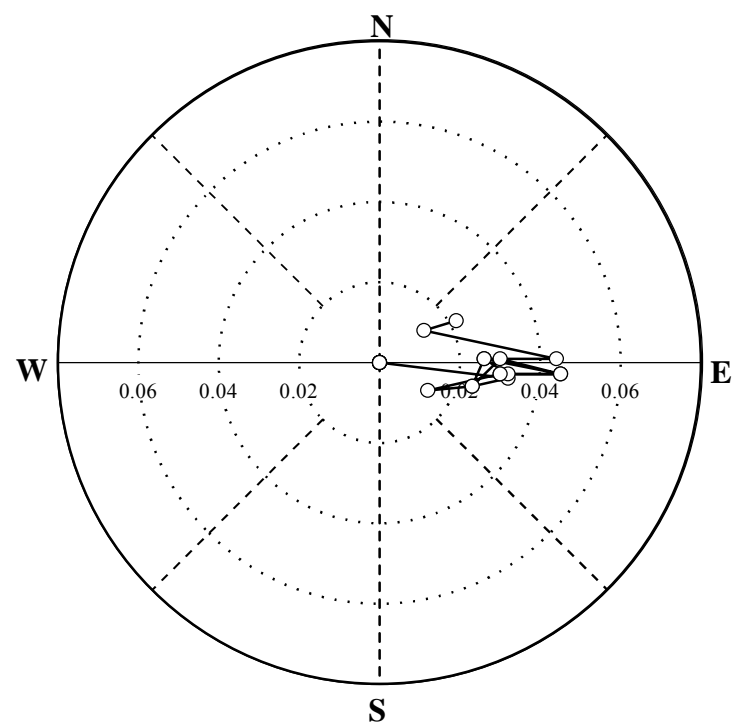

(c)

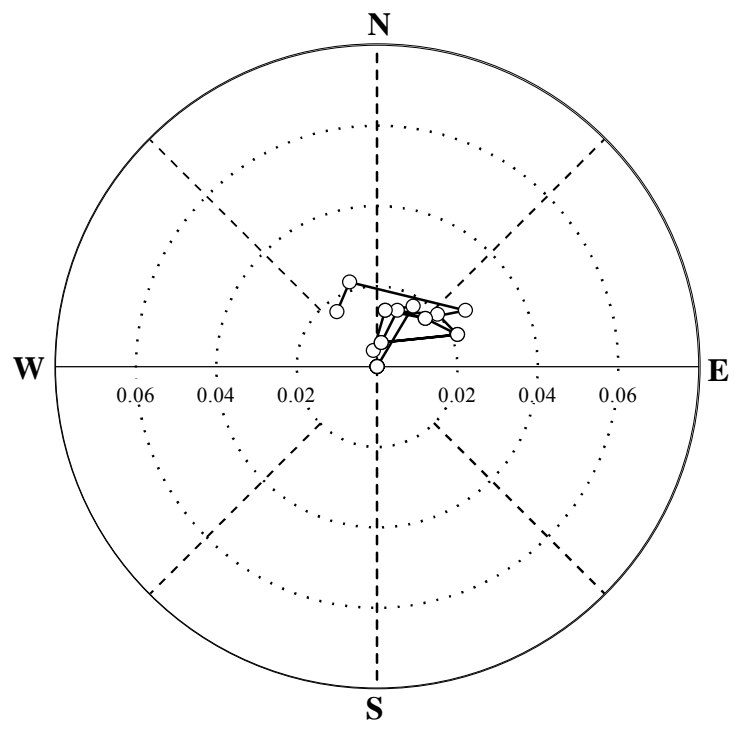

Figure 3.12. Creep Gauge Movement Between December 2001 and May 2004: (a) CG12, (b) CG13a, and (c) CG13b. (Elevation measured by EDM; the resultant [horizontal component] is in meters). 

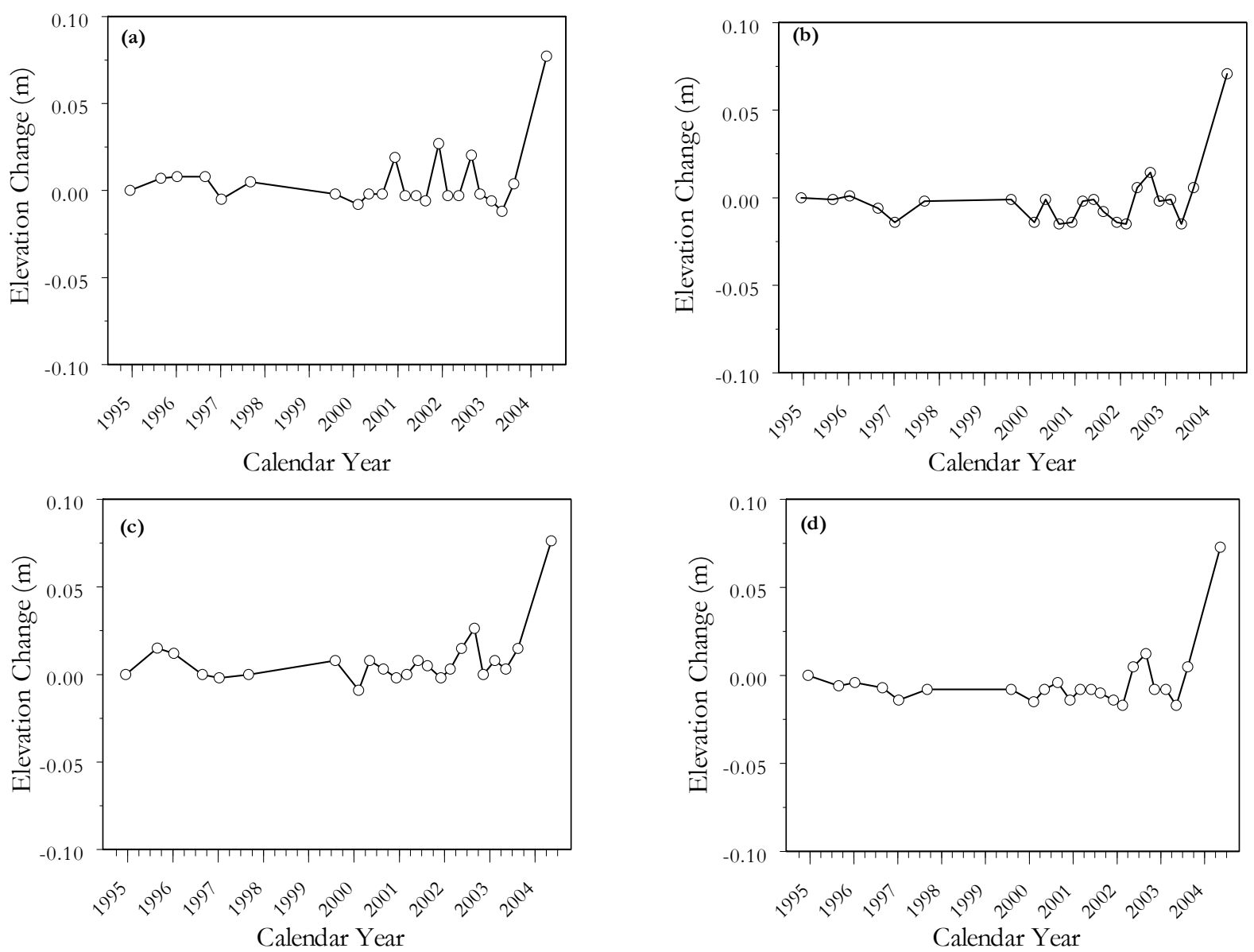

Figure 3.13. Creep Gauge Elevation Changes Between December 1994 and May 2004: (a) CG1, (b) CG2, (c) CG3, and (d) CG4. (Elevation Measured by EDM except in May 2004 by GPS.) 

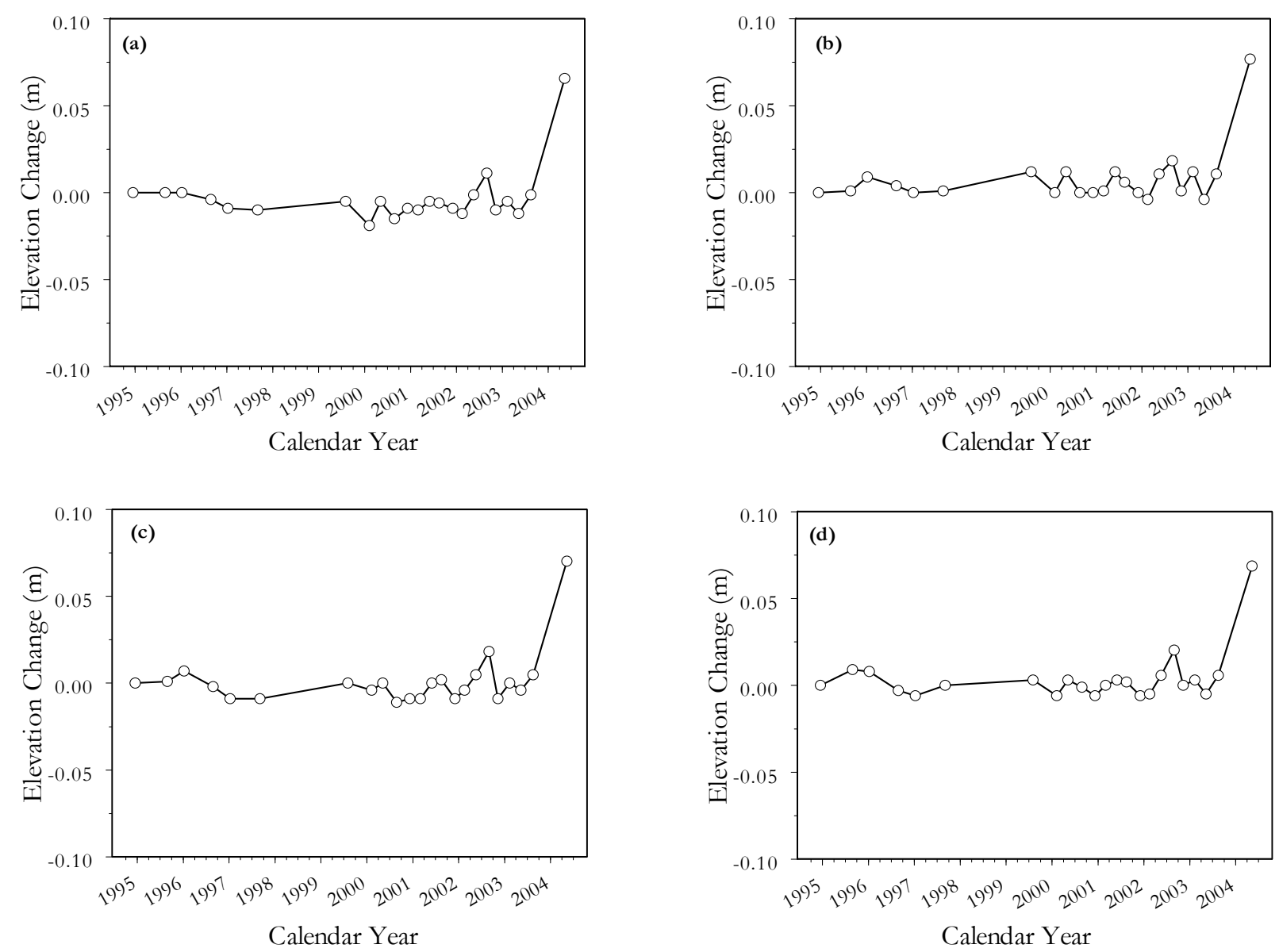

Figure 3.14. Creep Gauge Elevation Changes Between December 1994 and May 2004: (a) CG5, (b) CG6, (c) CG7, and (d) CG8. (Elevation Measured by EDM except in May 2004 by GPS.) 

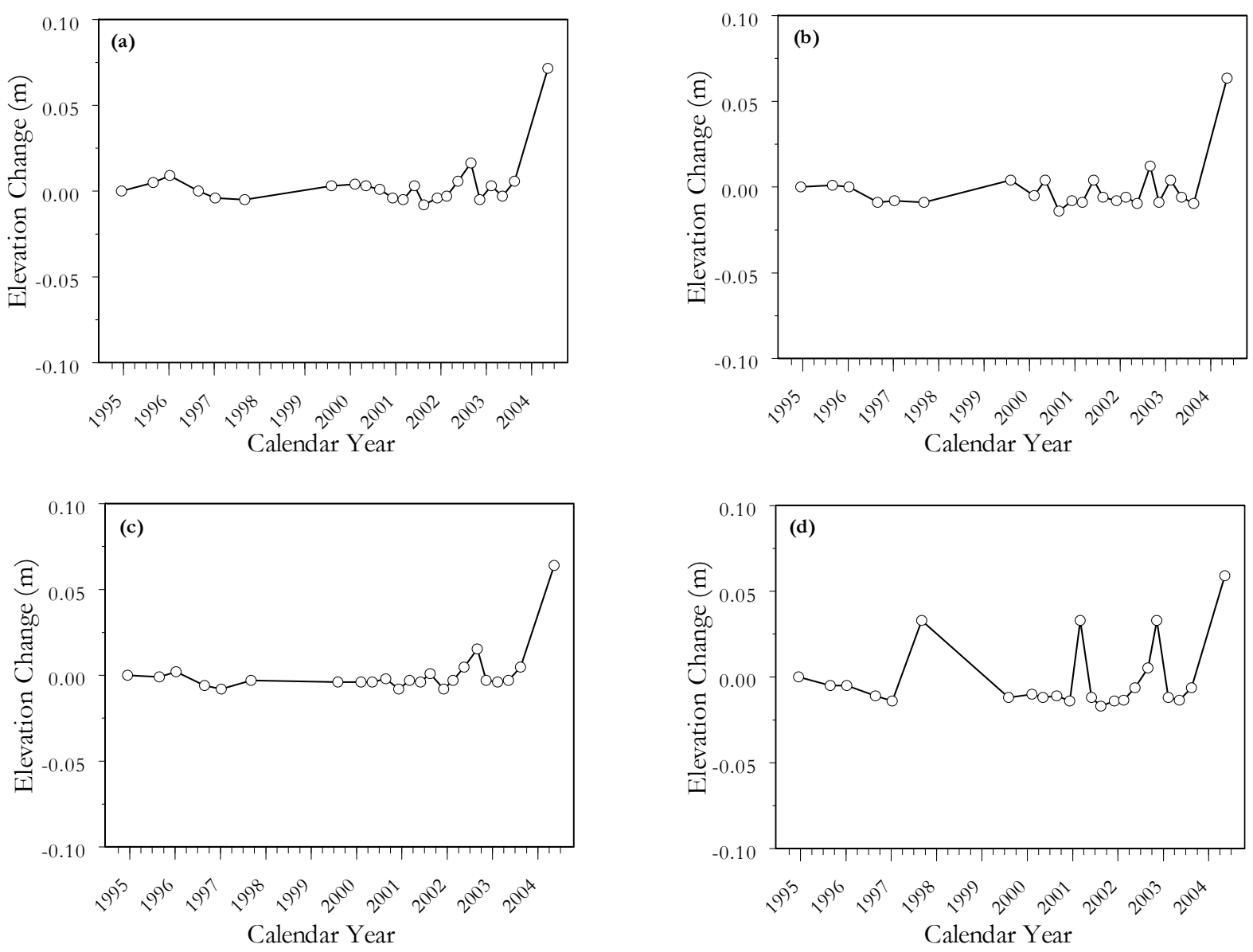

Figure 3.15. Creep Gauge Elevation Changes Between December 1994 and May 2004: (a) CG9, (b) CG10a, (c) CG10b, and (d) CG11. (Elevation Measured by EDM except in May 2004 by GPS.) 

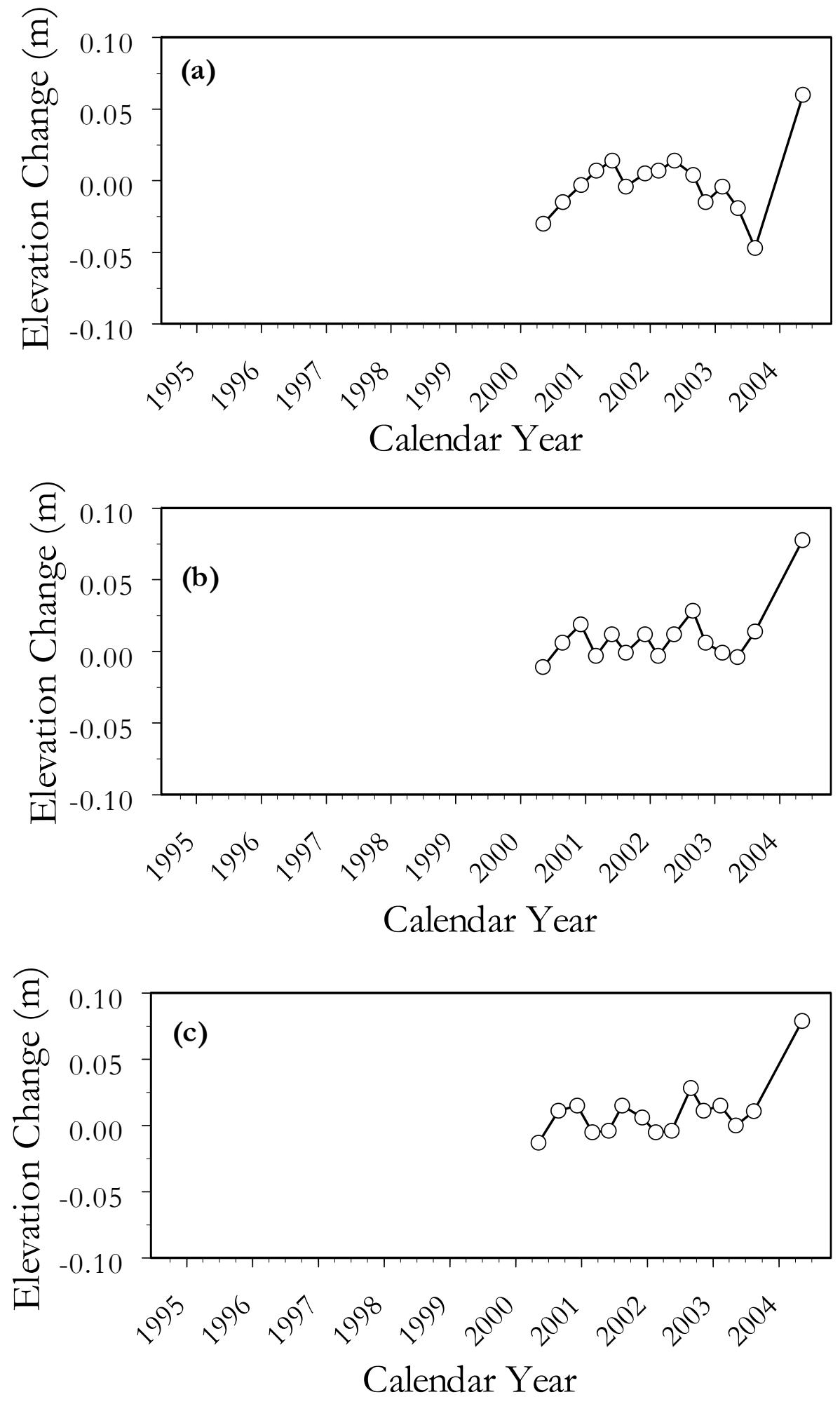

Figure 3.16. Creep Gauge Elevation Changes Between February 2000 and May 2004: for New Gauges (a) CG12, (b) CG13a, and (c) CG13b. (Elevation Measured by EDM except in May 2004 by GPS.) 


\subsubsection{Surface Elevation}

Figure 3.17 compares topographic contour maps of the barrier surface derived from EDM, aerial photogrammetry, and GPS. The DEMs of the prototype barrier, derived from the AP and GPS surveys, represent the elevation of the barrier digitally as an array of points. The horizontal spacing of the DEM and the vertical accuracy of the elevation determination govern the overall accuracy with which the barrier surface can be represented.

The EDM plot is based on a survey from August 15, 2003; the GPS plot is from a May 10, 2004, survey, while the aerial photogrammetry is based on data collected on August 17, 2004. The three methods show strong similarity in surface elevations and reflect the 2-percent slope of the engineered surface. The similarity between GPS (Figure 3.17b) and aerial photogrammetry (Figure 3.17c) are somewhat stronger. This may be because both techniques used the same control points.

To gain further insight into the differences between the three methods, elevation differences between GPS, AP, and EDM are presented in Figure 3.18. Figure 3.18a shows the difference between EDM and GPS (i.e., EDM-GPS). As expected, there are differences between the two, and the maximum appears to be consistent with those observed on the settlement gauges and creep gauges. On average, the precision of the horizontal measurements was about $0.007 \mathrm{~m}$ while the precision of the vertical measurements was about $0.009 \mathrm{~m}$. Differences between the EDM and GPS ranged from $-0.005 \mathrm{~m}$ to $+0.007 \mathrm{~m}$. These differences are caused by a combination of factors. Figure 3.19 shows the 3-D DEM resulting from the GPS survey.

Position accuracy will vary with the accuracy of the benchmark; GPS receiver configuration (receiver and antenna); location (geographic latitude and surrounding objects possibly blocking reception or causing multi-path reception); satellite constellation status; and ionosphere conditions. The availability of satellites and a good distribution generally provide greater accuracy. The timing of the survey can have an indirect effect on accuracy through its effect on the availability of satellites. In addition, there may also be some site-specific factors that may be affecting the accuracy of the results. Inspection of the surface shows depressions around many of the survey stakes that may have been caused by placement of the survey rod over the years. An underestimation of elevation is the most likely result of placing the rod adjacent to these stakes for a measurement.

Nevertheless, inspection of the barrier's surface shows no evidence of widespread changes in elevation. Differences between AP and EDM were somewhat smaller with a range from -0.004 to $+0.006 \mathrm{~m}$. Differences between AP and GPS, however, were quite small, ranging from -0.001 to $+0.005 \mathrm{~m}$. These differences may be due simply to the method of measurement. Both the AP and GPS techniques offer many advantages over traditional surveying techniques. Considerable costs are associated with conventional surveying technology. The EDM method, for example, is time-consuming and often requires multiple trips to the same site to gather data and to ensure that the collected data are accurate. In addition, workers must be trained to operate conventional surveying equipment properly. Weather also can delay data-collection surveys; crews are not always able to work under certain weather conditions, such as snow, rain, or extreme temperatures. Aerial photogrammetry can be used to obtain simultaneously the $3 \mathrm{D}$ coordinates at a large number of points. Because the images are obtained from the air, there is little chance of personnel coming in contact with dangerous conditions like steep slopes or contaminated surfaces. The results presented here clearly show that with a small number of photographs and relatively small amounts of computer time, the AP technique can be used to generate accurate highresolution topographic maps of the barrier. Aerial photos are relatively inexpensive, and the image 
(a) Electronic Distance Measurement

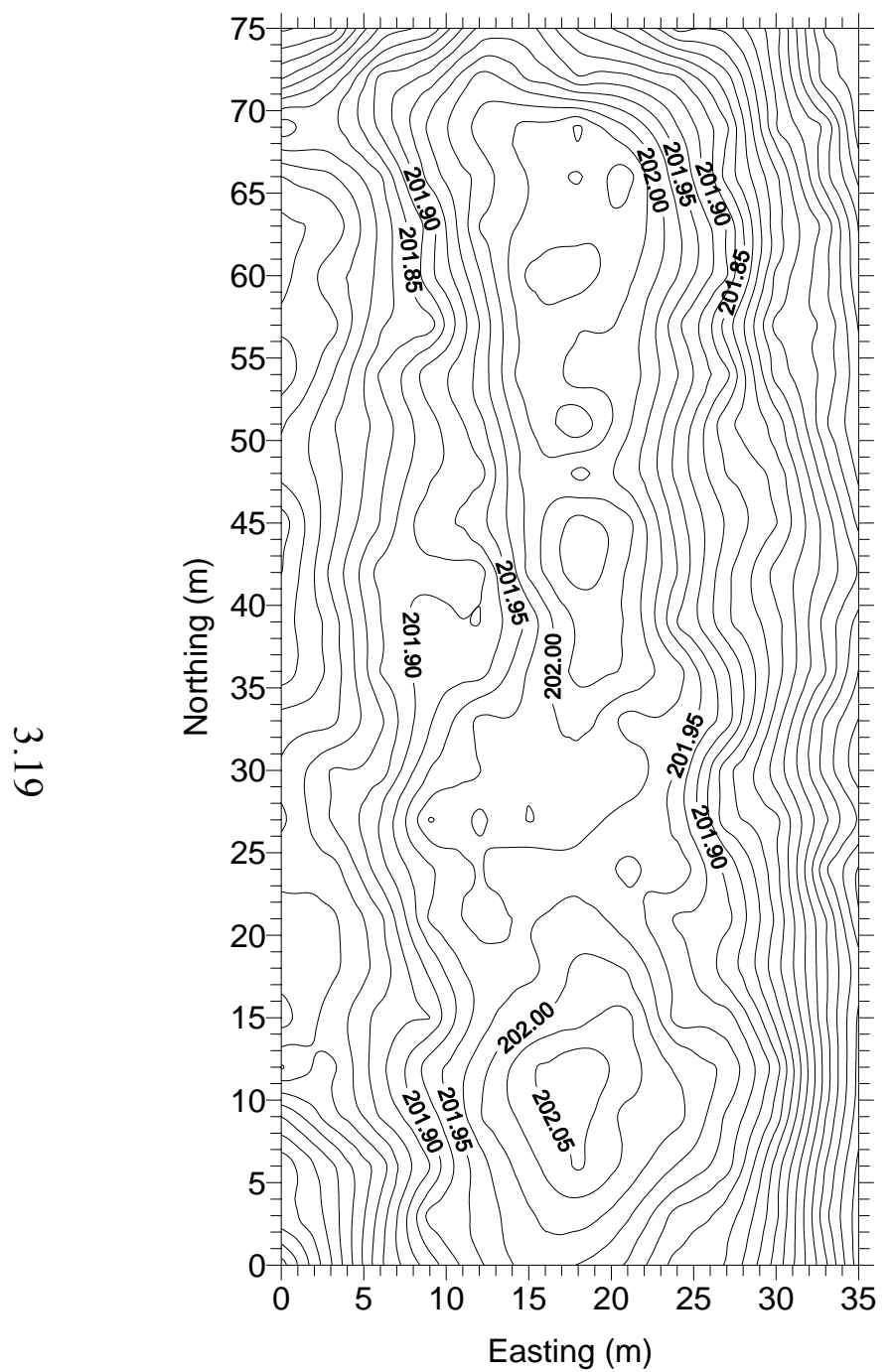

(b) Global Positioning System

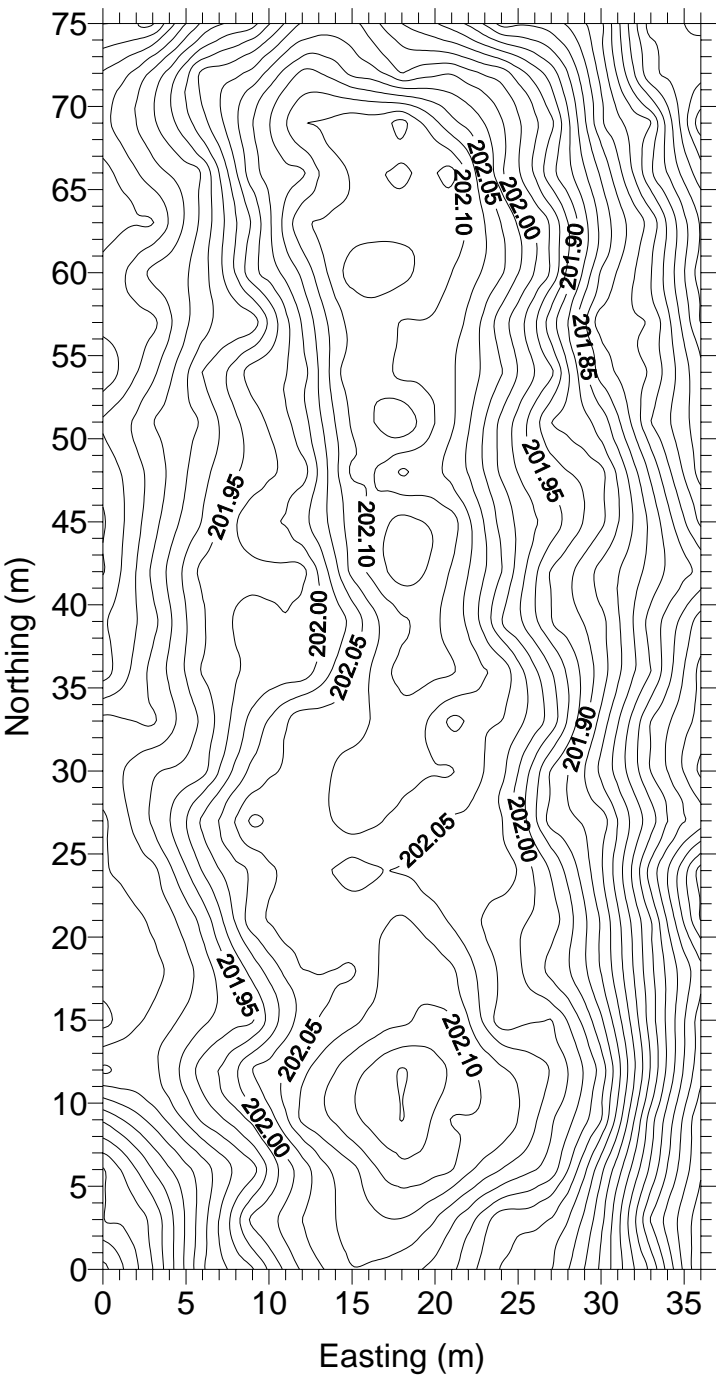

(c) Aerial Photogrammetry

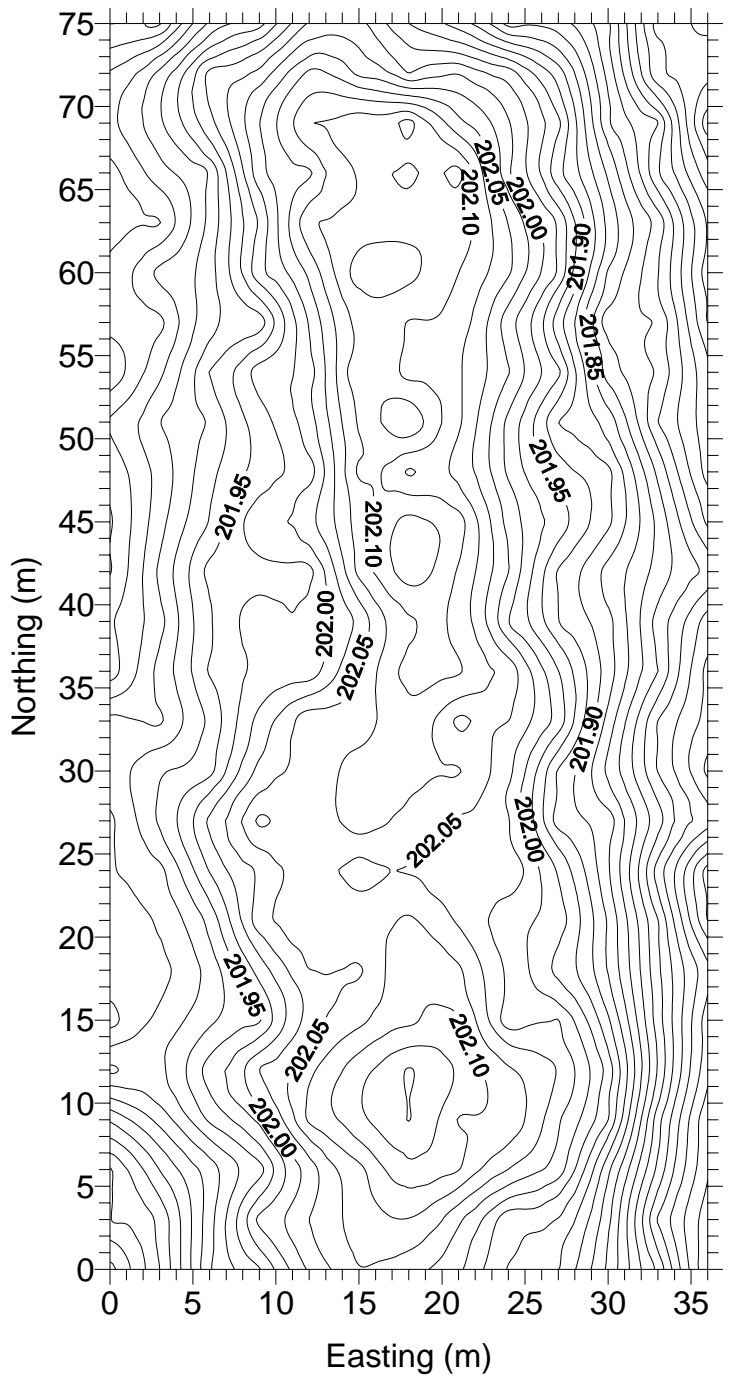

Figure 3.17. Surface Elevations in Meters at the Prototype Hanford Barrier as Measured by Three Different Methods: (a) Electronic Distance Measurement on August 15, 2003, (b) Global Positioning System Survey on May 10, 2004, and (c) Aerial Photographs taken on August 17, 2004. The contour interval is 0.025 m. 
(a) EDM-GPS

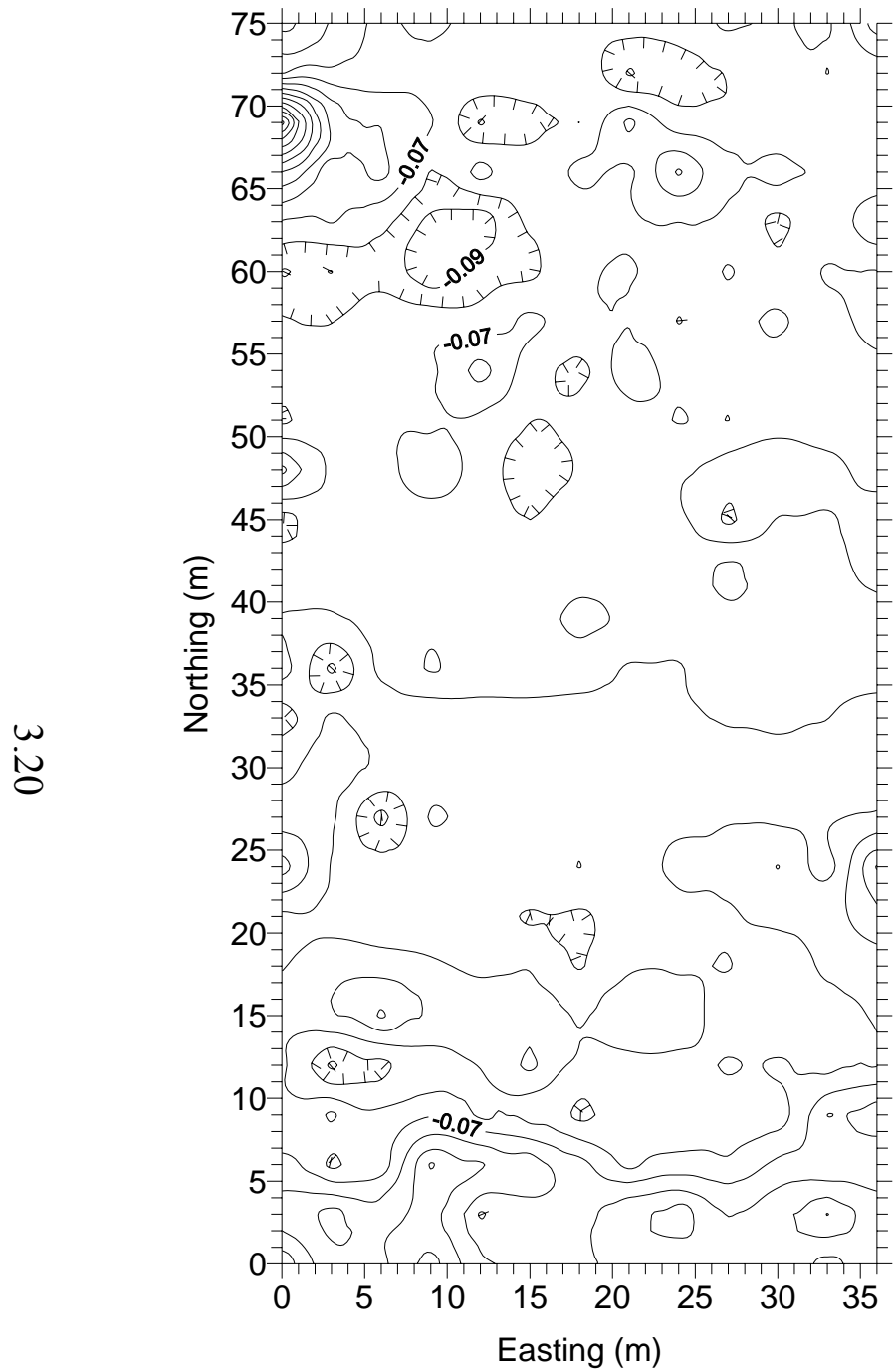

(b) EDM-Aerial Photogrammetry

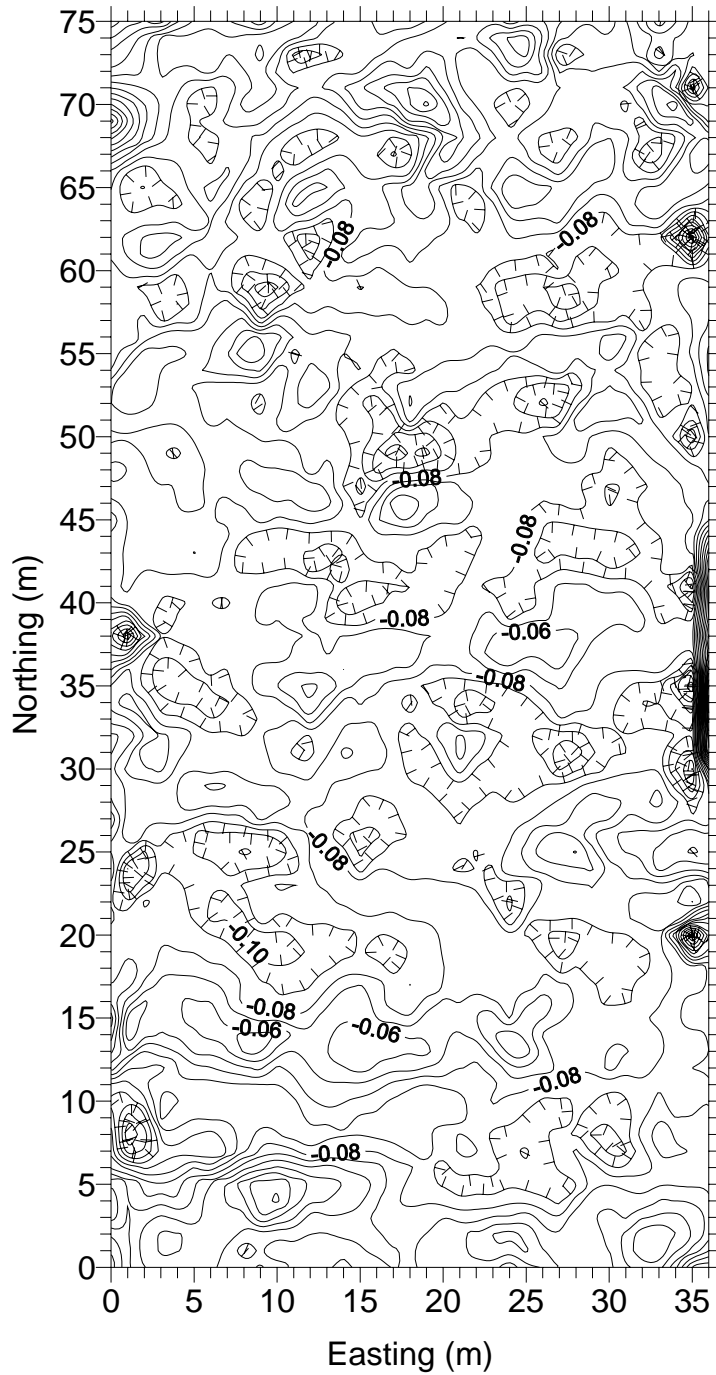

(c) GPS-Aerial Photogrammetry

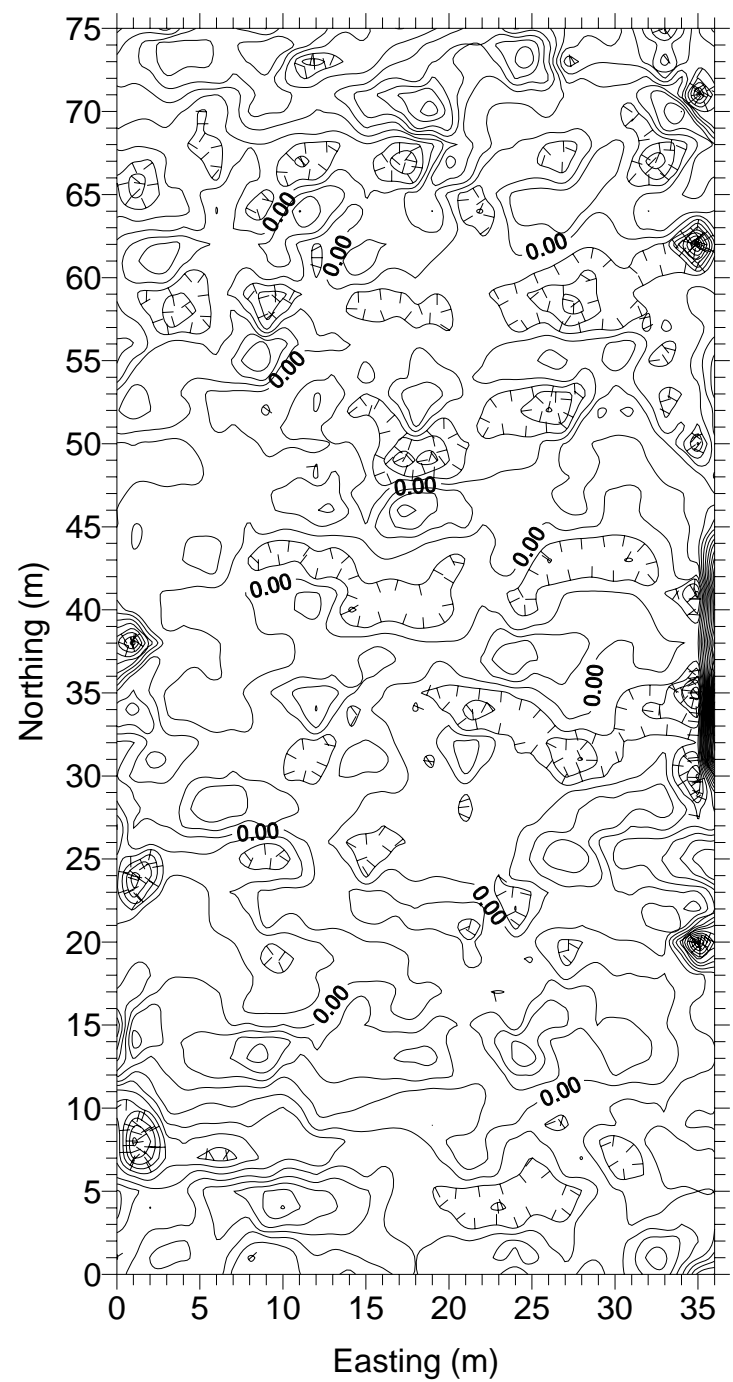

Figure 3.18. Differences in Surface Elevation (meters) as Measured by Three Methods Measured by Three Different Methods:

(a) between EDM and GPS, (b) between EDM and aerial photogrammetry, and (c) Between GPS and Aerial Photogrammetry. The contour interval is $0.01 \mathrm{~m}$ ). 


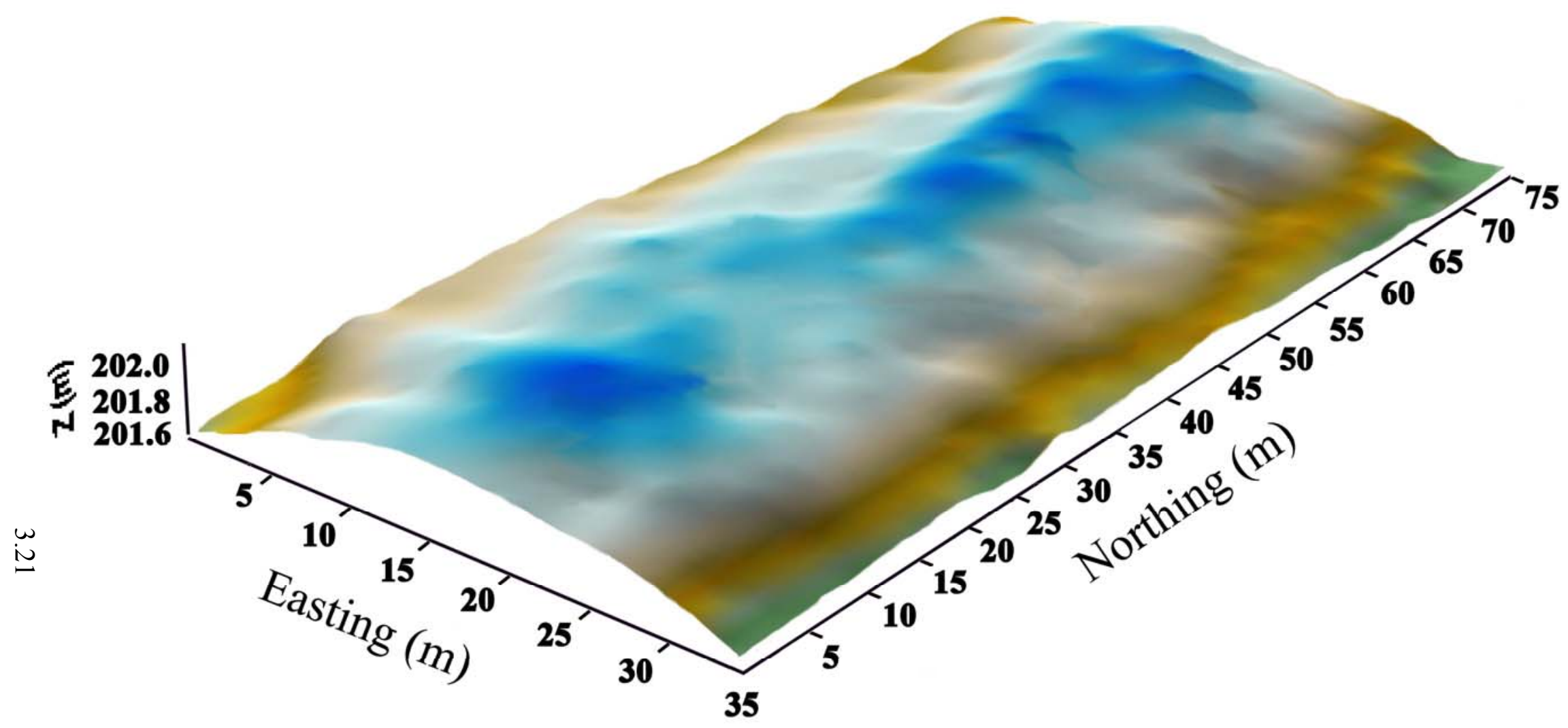

Figure 3.19. Surface Elevation (10 $\times$ Vertical Exaggeration) at the Prototype Hanford Barrier as of May 10, 2004 Measured Using a Real-Time Kinematic Global Position System. 
processing that results in the DEM can be completed in a matter of minutes compared to the typical 48 to 72 hours using the EDM method. The GPS method also offers several advantages. Over the past 5 years, a number of studies have shown that GPS technology increases the productivity of conventional survey crews, reduces data-collection time, improves survey accuracy, and allows crews to work under a broad range of weather conditions. Moreover, less expertise is required to operate a GPS surveying unit than is needed to operate conventional surveying technologies. Thus, the AP and GPS techniques could be good replacements for the conventional EDM surveys. Because of the differences between the three methods, calculating the difference between the first survey in 1994 and the current survey is not recommended. However, the FY 2004 results can be used as a baseline for future surveys by AP or GPS.

\subsection{Recommendations for Fiscal Year 2005}

Subsidence is one mechanism that potentially can impair barrier functionality. At the prototype barrier, subsidence has been monitored by observing changes in elevation using traditional surveying techniques. In FY 2004, two additional methods were investigated: surveying by aerial photogrammetry and the global positioning system. Results show potential for considerable costs savings and increased accuracy. The AP method also shows some potential for use in identifying plant species and mapping vegetative cover at considerable cost savings. It is recommended that the proof-of-principle study be extended to a field study to further evaluate the potential of aerial photogrammetry as a means of quantifying landscape-scale patterns of elevation and vegetation distribution and dynamics for final covers.

\subsection{Summary}

Stability monitoring continued in FY 2004 with one survey of elevation on the surface, the two settlement gauges, and 12 creep gauges. Instead of the conventional EDM survey, aerial photogrammetry and a global-positioning survey were used. The movement in the settlement gauges showed no trend through FY 2003. The FY 2004 survey showed an increase in elevation over the FY 2003 results, but this is attributed to the change in survey methods. The three creep gauges installed in FY 2000 to allow closer monitoring of the southeastern corner of the riprap side slope continued to be monitored quarterly and show no predominant trend. Creep-gauge CG1 continues to show the most movement with a net horizontal displacement of about $0.051 \pm 0.016 \mathrm{~m}$ since 1994. Changes in the vertical displacement of the 15 creep gauges over time showed no obvious trends through May 2004. An increase in elevation relative to FY 2003 is due to a change in surveying methods from EDM to real-time kinematic GPS. There is no evidence to support the observed change in elevation; thus the difference may be due to a difference in precision for elevation measurements based on the GPS survey.

In FY 2004, aerial photography has long been used as an efficient method of generating topographic maps and, more recently, digital elevation models for geomorphic applications. Automated digital photogrammetry is a relatively new technique with much potential, but routine use has been limited by the need for expensive third-party software. During the last year, automated digital photogrammetry was applied to aerial photographs of the prototype barrier to examine the feasibility of using this technique for monitoring elevation. Results show that with a small number of photographs and relatively small amounts of computer time, this technique allowed the extraction of accurate high-resolution topographic maps of the barrier. This technique appears ideally suited to monitoring multiple barriers and other sites that may be difficult or dangerous to survey, especially when time and resources are limited. Both AP and GPS show potential for considerable cost savings without any loss in accuracy. 


\subsection{Vegetation}

This section discusses the methodology and the results of measuring vegetation on the surface of the prototype Hanford barrier and side slopes.

\subsection{Methodology}

Surveys of vegetation and animal use of the Prototype Hanford Barrier and side slopes were conducted on April 23, 2004. Field parameters measured for vegetation were shrub height, canopy area, and canopy cover. Cover classes for grass, shrubs, litter, bare ground, and plant species present were recorded. Evidence of animal activity, especially burrowing, was evaluated for the barrier surface and side slopes. The maximum height, width, and length of 25 shrubs each in the northern (irrigated in 1995, 1996, and 1997) and southern (non-irrigated) areas of the barrier surface were measured consistent with the methods used in DOE-RL (1999). The height of the highest stem, the greatest canopy diameter, and the diameter at the center of the plant perpendicular to the greatest diameter were measured. The measured shrubs were chosen randomly, regardless of species (sagebrush [Artemisia tridentata] or gray rabbitbrush [Chrysothamnus nauseosus]).

Cover classes of shrubs, grasses, litter, and bare ground were estimated using the technique of Daubenmire 1959, "A Canopy-Coverage Method of Vegetational Analysis," and DOE-RL (1999). Cover by herbaceous forbs was not quantified in 2004, as this type of vegetation was extremely sparse and did not contribute significantly to canopy cover on the barrier surface. The plant species on the formerly irrigated and non-irrigated sections of the barrier, and on the barrier side slopes, were identified and compared to previous years.

Survivorship of shrubs was not assessed using counts of individual plants in 2004. Observations made over the past several years have indicated that numeric counts of live shrubs have become less meaningful because of the relative stability of the plant community on the barrier surface. General observations related to survival are presented in the results discussion below.

\subsection{Results}

Sagebrush dominates the shrub cover of the Prototype Hanford Barrier. Rabbitbrush is sparse on the barrier surface, with very few plants in either treatment (formerly irrigated and non-irrigated). Five of 25 plants in the formerly irrigated section, and 2 of 25 plants in the non-irrigated section of the barrier were rabbitbrush. The mean height and canopy area of individual sagebrush increased slightly from 2003 to 2004 in the formerly irrigated and non-irrigated portions of the barrier. The mean height and canopy area of rabbitbrush shrubs in the formerly irrigated portion increased slightly, while the height and area of rabbitbrush non-irrigated treatment has remained relatively the same between 2003 and 2004.

Summarized shrub measurement results are shown in Table 4.1. Detailed shrub measurements are included in Tables B.1 and B.2 in Appendix B. 
Table 4.1. Shrub Measurement Summary Data of 2004 on the Prototype Hanford Barrier

\begin{tabular}{|c|c|c|c|c|}
\hline \multirow[b]{2}{*}{ Dimension } & \multicolumn{2}{|c|}{ Irrigated } & \multicolumn{2}{|c|}{ Non-Irrigated } \\
\hline & $\operatorname{Mean}^{(a)}$ & Range $^{(a)}$ & $\operatorname{Mean}^{(a)}$ & Range $^{(a)}$ \\
\hline \multicolumn{5}{|c|}{ Sagebrush } \\
\hline Area $\left(\mathrm{cm}^{2}\right)$ & $\begin{array}{c}4,449 \\
(3,294)\end{array}$ & $\begin{array}{l}370-15,456 \\
(690-6,975)\end{array}$ & $\begin{array}{c}4,808 \\
(3,224)\end{array}$ & $\begin{array}{c}504-8,200 \\
(481-8,187)\end{array}$ \\
\hline Height $(\mathrm{cm})$ & $\begin{array}{c}69 \\
(65)\end{array}$ & $\begin{array}{l}30-118 \\
(40-80)\end{array}$ & $\begin{array}{c}66 \\
(61)\end{array}$ & $\begin{array}{c}40-92 \\
(20-82)\end{array}$ \\
\hline \multicolumn{5}{|c|}{ Rabbitbrush $^{(b)}$} \\
\hline Area $\left(\mathrm{cm}^{2}\right)$ & $\begin{array}{c}3,600 \\
(2,851)\end{array}$ & $\begin{array}{c}680-9,188 \\
(325-2,950)\end{array}$ & $\begin{array}{c}821 \\
(850)\end{array}$ & $\begin{array}{c}782-860 \\
(240-1,250)\end{array}$ \\
\hline Height (cm) & $\begin{array}{c}54 \\
(66)\end{array}$ & $\begin{array}{c}38-68 \\
(42-64)\end{array}$ & $\begin{array}{c}35 \\
(31)\end{array}$ & $\begin{array}{c}30-39 \\
(21-50)\end{array}$ \\
\hline
\end{tabular}

Very few live rabbitbrush shrubs were observed in the non-irrigated treatment. Qualitatively speaking, the overall survival of rabbitbrush has declined noticeably on the barrier surface in recent years.

Sagebrush continues to thrive, with evidence of recruitment by sagebrush seedlings across the barrier surface. Cryptogamic crust has also begun to develop within both treatments on the barrier surface.

The mean, median, and mode cover classes for each cover type in the formerly irrigated and non-irrigated treatments of the barrier are shown in Table 4.2. (The ranges shown are the cover classes as defined by Daubenmire [1959].) Detailed canopy cover analyses are included in Appendix B (Tables B.3 and B.4), and total percent canopy coverage for the Prototype Hanford Barrier is presented in Table B.5. Consistent with previous years, the formerly irrigated section had greater cover of grasses and litter than the nonirrigated section. Native bunchgrasses have established across the barrier surface and are higher in density along the perimeter of the barrier. Cheatgrass (Bromus tectorum) and Russian thistle (Salsola kali) are nearly nonexistent on the barrier surface.

The cover on the north and west side slopes was relatively uniform, consisting of native grasses, forbs, and shrubs. Invasive species such as Russian thistle and cheatgrass were infrequently observed along the barrier side slopes.

Table 4.3 identifies vegetation species on the formerly irrigated and non-irrigated treatments of the barrier. Figure 4.1 compares the total number of annual and perennial species on the barrier surface from 1995 to 2004. Table 4.4 lists vegetation species identified on the barrier side slopes. Table 4.5 compares the species identified on the barrier surface in 2004 against those identified from 1995 to 2003 . A species list was not compiled in 1998. 
Table 4.2. Median, Mode, and Mean Percent Cover Classes Ranges (2 pages)

\begin{tabular}{|c|c|c|c|c|c|}
\hline Cover Class & Treatment & Water Year & Median & Mode & Mean \\
\hline \multirow{16}{*}{ Grass } & \multirow{8}{*}{ Irrigated } & 1996 & $25-50$ & $5-25$ & \\
\hline & & 1997 & $50-75$ & $50-75$ & \\
\hline & & 1999 & $75-95$ & $75-95$ & $50-75$ \\
\hline & & 2000 & $75-95$ & $75-95$ & $50-75$ \\
\hline & & 2001 & $75-95$ & $75-95$ & $25-50$ \\
\hline & & 2002 & $5-25$ & $5-25$ & $5-25$ \\
\hline & & 2003 & $5-25$ & $5-25$ & $5-25$ \\
\hline & & 2004 & $5-25$ & $5-25$ & $25-50$ \\
\hline & \multirow{8}{*}{ Non-Irrigated } & 1996 & $5-25$ & $5-25$ & \\
\hline & & 1997 & $25-50$ & $25-50$ & \\
\hline & & 1999 & $25-50$ & $25-50$ & $25-50$ \\
\hline & & 2000 & $5-25$ & $5-25$ & $25-50$ \\
\hline & & 2001 & $5-25$ & $5-25$ & $5-25$ \\
\hline & & 2002 & $0-5$ & $0-5$ & $0-5$ \\
\hline & & 2003 & $5-25$ & $0-5$ & $5-25$ \\
\hline & & 2004 & $0-5$ & $0-5$ & $5-25$ \\
\hline \multirow{16}{*}{ Shrub } & \multirow{8}{*}{ Irrigated } & 1996 & $0-5$ & $0-5$ & \\
\hline & & 1997 & $25-50$ & $25-50$ & \\
\hline & & 1999 & $25-50$ & $25-50$ & $25-50$ \\
\hline & & 2000 & $50-75$ & $50-75$ & $25-50$ \\
\hline & & 2001 & $25-50$ & $25-50$ & $25-50$ \\
\hline & & 2002 & $25-50$ & $25-50$ & $25-50$ \\
\hline & & 2003 & $25-50$ & $25-50$ & $25-50$ \\
\hline & & 2004 & $25-50$ & $25-50$ & $25-50$ \\
\hline & \multirow{8}{*}{ Non-irrigated } & 1996 & $0-5$ & $0-5$ & \\
\hline & & 1997 & $25-50$ & $25-50$ & \\
\hline & & 1999 & $25-50$ & $25-50$ & $25-50$ \\
\hline & & 2000 & $25-50$ & $25-50$ & $25-50$ \\
\hline & & 2001 & $25-50$ & $25-50$ & $25-50$ \\
\hline & & 2002 & $5-25$ & $5-25$ & $5-25$ \\
\hline & & 2003 & $25-50$ & $25-50$ & $25-50$ \\
\hline & & 2004 & $25-50$ & $25-50$ & $25-50$ \\
\hline
\end{tabular}


Table 4.2. Median, Mode, and Mean Percent Cover Classes Ranges (2 pages)

\begin{tabular}{|c|c|c|c|c|c|}
\hline Cover Class & Treatment & Water Year & Median & Mode & Mean \\
\hline \multirow{16}{*}{ Litter } & \multirow{8}{*}{ Irrigated } & 1996 & 5-25 & $5-25$ & \\
\hline & & 1997 & $50-75$ & $50-75$ & \\
\hline & & 1999 & $75-95$ & $95-100$ & $75-95$ \\
\hline & & 2000 & $75-95$ & $75-95$ & $50-75$ \\
\hline & & 2001 & $25-50$ & $25-50$ & $50-75$ \\
\hline & & 2002 & $50-75$ & $25-50$ & $50-75$ \\
\hline & & 2003 & $25-50$ & $25-50$ & $25-50$ \\
\hline & & 2004 & $50-75$ & $50-75$ & $50-75$ \\
\hline & \multirow{8}{*}{ Non-irrigated } & 1996 & $5-25$ & $5-25$ & \\
\hline & & 1997 & $25-50$ & $25-50$ & \\
\hline & & 1999 & $50-75$ & $50-75$ & $50-75$ \\
\hline & & 2000 & $25-50$ & $25-50$ & $25-50$ \\
\hline & & 2001 & $25-50$ & $5-25$ & $25-50$ \\
\hline & & 2002 & $25-50$ & $25-50$ & $25-50$ \\
\hline & & 2003 & $5-25$ & $5-25$ & $5-25$ \\
\hline & & 2004 & $25-50$ & $25-50$ & $25-50$ \\
\hline \multirow{16}{*}{ Bare Ground } & \multirow{8}{*}{ Irrigated } & 1996 & $5-25$ & $5-25$ & \\
\hline & & 1997 & $5-25$ & $25-50$ & \\
\hline & & 1999 & $5-25$ & $0-5$ & $5-25$ \\
\hline & & 2000 & $5-25$ & $5-25$ & $5-25$ \\
\hline & & 2001 & $5-25$ & $5-25$ & $5-25$ \\
\hline & & 2002 & $25-50$ & $25-50$ & $25-50$ \\
\hline & & 2003 & $50-75$ & $50-75$ & $25-50$ \\
\hline & & 2004 & $25-50$ & $50-75$ & $25-50$ \\
\hline & \multirow{8}{*}{ Non-irrigated } & 1996 & $5-25$ & $5-25$ & \\
\hline & & 1997 & $25-50$ & $25-50$ & \\
\hline & & 1999 & $5-25$ & $5-25$ & $25-50$ \\
\hline & & 2000 & $25-50$ & $50-75$ & $25-50$ \\
\hline & & 2001 & $25-50$ & $25-50$ & $25-50$ \\
\hline & & 2002 & $25-50$ & $25-50$ & $25-50$ \\
\hline & & 2003 & $50-75$ & $75-95$ & $50-75$ \\
\hline & & 2004 & $50-75$ & $50-75$ & $50-75$ \\
\hline
\end{tabular}




$\begin{array}{ccc}\text { Class } & \text { Percent Cover } & \text { Midpoint } \\ 1 & 0 \text { to } 5 & 2.5 \\ 2 & 5 \text { to } 25 & 15 \\ 3 & 25 \text { to } 50 & 37.5 \\ 4 & 50 \text { to } 75 & 62.5 \\ 5 & 75 \text { to } 95 & 85 \\ 6 & 95 \text { to } 100 & 97.5\end{array}$

Table 4.3. Plant Species Observed in 2004 on the Prototype Hanford Barrier Surface, Formerly Irrigated and Non-Irrigated Sections

\begin{tabular}{|c|c|c|}
\hline Species & Irrigated & Non-Irrigated \\
\hline Amsinckia lycopsoides (Tarweed fiddleneck) & & $\mathrm{X}$ \\
\hline Artemisia tridentata (Big sagebrush) & $\mathrm{X}$ & $\mathrm{X}$ \\
\hline Bromus tectorum (Cheatgrass) & $\mathrm{X}$ & $\mathrm{X}$ \\
\hline Chrysothamnus nauseosus (Gray rabbitbrush) & $\mathrm{X}$ & $\mathrm{X}$ \\
\hline Erodium cicutarium (Storksbill) & $\mathrm{X}$ & $\mathrm{X}$ \\
\hline Festuca octoflora (Six-weeks fescue) & $\mathrm{X}$ & $\mathrm{X}$ \\
\hline Lactuca serriola (Prickly lettuce) & $\mathrm{X}$ & \\
\hline Machaeranthera canescens (Hoary aster) & $\mathrm{X}$ & $\mathrm{X}$ \\
\hline Poa bulbosa (Bulbous bluegrass) & $\mathrm{X}$ & $\mathrm{X}$ \\
\hline Poa sandbergii (Sandberg's bluegrass) & $\mathrm{X}$ & $\mathrm{X}$ \\
\hline Pseudoroegneria spicata (Bluebunch wheatgrass) & $\mathrm{X}$ & $\mathrm{X}$ \\
\hline Salsola kali (Russian thistle) & $\mathrm{X}$ & $\mathrm{X}$ \\
\hline Sphaeralcea munroana (Munro's globemallow) & & $\mathrm{X}$ \\
\hline Tragopogon dubius (Yellow salsify) & $\mathrm{X}$ & $\mathrm{X}$ \\
\hline Total Number of Species Present: & 12 & 13 \\
\hline
\end{tabular}




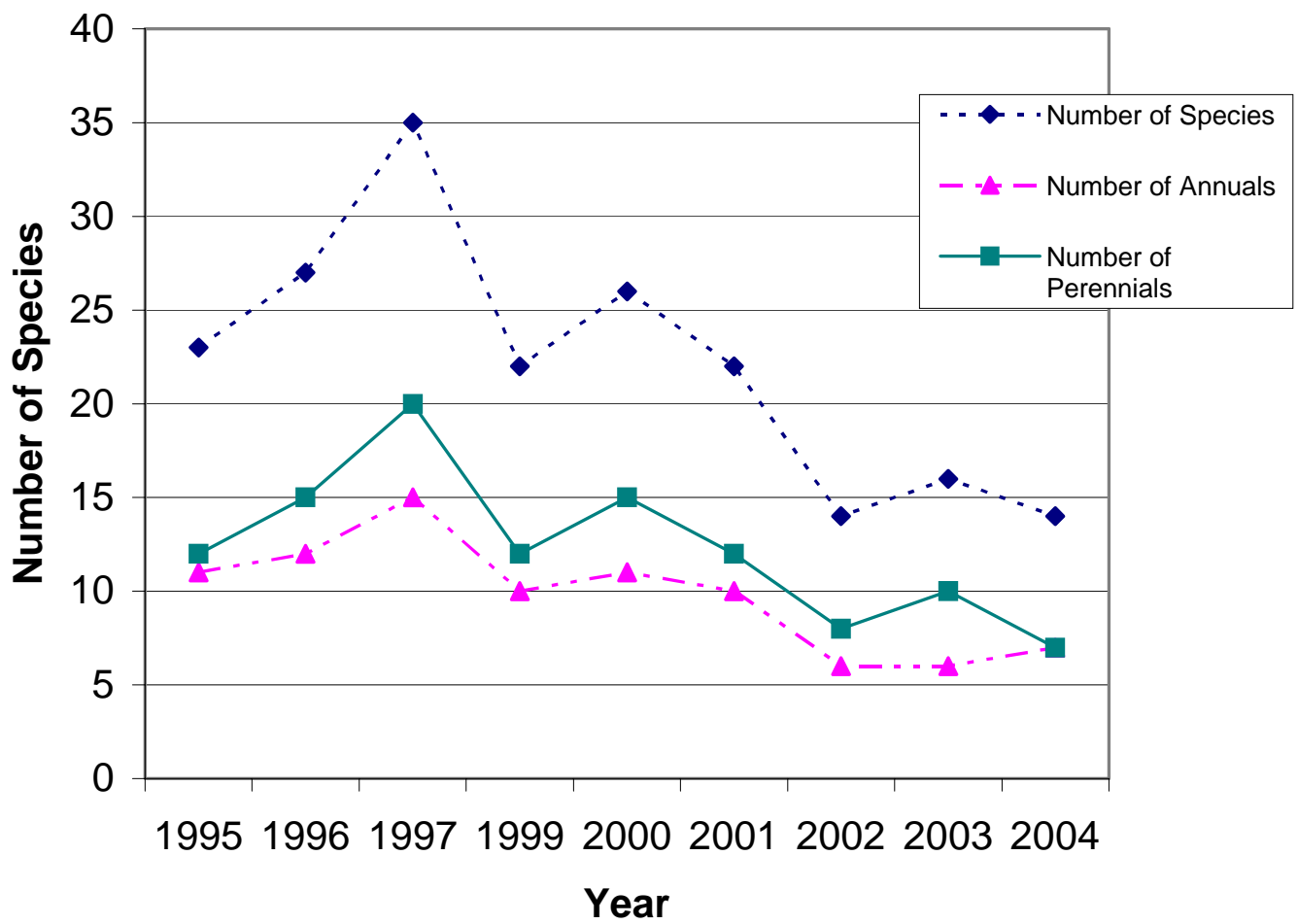

Figure 4.1. Temporal Variation in the Number of Annual and Perennial Species Including Total Species on the Prototype Hanford Barrier

Table 4.4. Plant Species Observed in 2004 on the North and West Side Slopes of the Prototype Hanford Barrier

\begin{tabular}{||l|l||}
\hline Achillea millefolium (yarrow) & Epilobium paniculatum (Tall willowherb) \\
\hline Agropyron spicatum (Bluebunch wheatgrass) & Erigeron spp. \\
\hline Ambrosia acanthicarpa (Bur ragweed) & Erodium cicutarium (Storksbill) \\
\hline Amsinckia lycopsoides (Tarweed fiddleneck) & Festuca octoflora (Six-weeks fescue) \\
\hline Artemisia tridentata (Big sagebrush) & Holosteum umbellatum (Jagged chickweed) \\
\hline Astragalus spp. (milkvetch species) & Lactuca serriola (Prickly lettuce) \\
\hline Bromus tectorum (Cheatgrass) & Lupinus pusillus (Low lupine) \\
\hline Chaenactis douglasii (Hoary falseyarrow) & Machaeranthera canescens (Hoary aster) \\
\hline Chrysothamnus nauseosus (Gray rabbitbrush) & Melilotus alba (White sweetclover) \\
\hline Chrysothamnus viscidiflorus (Green rabbitbrush) & Poa sandbergii (Sandberg's bluegrass) \\
\hline Draba verna (Spring whitlowgrass) & Salsola kali (Russian thistle) \\
\hline \multicolumn{2}{|c|}{ Total number of species: 22} \\
\hline
\end{tabular}


Table 4.5. Plant Species Observed on the Prototype Hanford Barrier in Previous Years ${ }^{(a)}$ (3 pages)

\begin{tabular}{|c|c|c|c|c|c|c|c|c|c|c|c|c|}
\hline \multicolumn{2}{|c|}{ Scientific Name } & \multirow[b]{2}{*}{ Common Name } & \multirow[b]{2}{*}{$\begin{array}{c}\text { Species } \\
\text { Type }\end{array}$} & \multicolumn{9}{|c|}{ Presence (WY) } \\
\hline Family & Species & & & 녕 & ஜே & बิ & g & ฮั่ & 호․ & ชิ & ชิ & ষ্ণ \\
\hline Boraginaceae & Amsinckia lycopsoides & Tarweed fiddleneck & $\mathrm{N}, \mathrm{AF}$ & $\mathrm{X}$ & $\mathrm{X}$ & $\mathrm{X}$ & $\mathrm{X}$ & $\mathrm{X}$ & $\mathrm{X}$ & $\mathrm{X}$ & $X$ & $\mathrm{X}$ \\
\hline \multirow{5}{*}{ Brassicaceae } & Cardaria draba & Whitetop & $\mathrm{I}, \mathrm{PF}$ & & $X$ & $\mathrm{X}$ & $\mathrm{X}$ & $\mathrm{X}$ & & & & \\
\hline & Chorispora tenella & Blue mustard & $\mathrm{I}, \mathrm{AF}$ & $X$ & & $\mathrm{X}$ & & & & & & \\
\hline & Descurainia pinnata & Western tansymustard & $\mathrm{N}, \mathrm{AF}$ & $\mathrm{X}$ & $\mathrm{X}$ & $\mathrm{X}$ & & & & & & \\
\hline & Draba verna & Spring whitlowgrass & $\mathrm{I}, \mathrm{AF}$ & $\mathrm{X}$ & $\mathrm{X}$ & $\mathrm{X}$ & $X$ & $\mathrm{X}$ & $X$ & $X$ & & \\
\hline & Sisymbrium altissimum & Tumblemustard & $\mathrm{I}, \mathrm{AF}$ & $X$ & $\mathrm{X}$ & $X$ & & $X$ & & & $X$ & \\
\hline Carhophyllaceae & Holosteum umbellatum & Jagged chickweed & $\mathrm{I}, \mathrm{AF}$ & & & & $X$ & $\mathrm{X}$ & $X$ & $\mathrm{X}$ & $\mathrm{X}$ & \\
\hline \multirow{2}{*}{ Chenopodiaceae } & Chenopodium leptophyllum & Slimleaf goosefoot & $\mathrm{N}, \mathrm{AF}$ & $\mathrm{X}$ & $\mathrm{X}$ & $\mathrm{X}$ & & & & & & \\
\hline & Salsola kali & Russian thistle & $\mathrm{I}, \mathrm{AF}$ & $\mathrm{X}$ & $\mathrm{X}$ & $\mathrm{X}$ & $\mathrm{X}$ & $\mathrm{X}$ & $\mathrm{X}$ & & $\mathrm{X}$ & $\mathrm{X}$ \\
\hline \multirow{10}{*}{ Compositae } & Achillea millefolium & Yarrow & $\mathrm{N}, \mathrm{PF}$ & $\mathrm{X}$ & & $\mathrm{X}$ & $\mathrm{X}$ & $\mathrm{X}$ & $\mathrm{X}$ & & & \\
\hline & Ambrosia acanthicarpa & Bur ragweed & $\mathrm{N}, \mathrm{PF}$ & $\mathrm{X}$ & & $\mathrm{X}$ & & $\mathrm{X}$ & & & & \\
\hline & Artemisia tridentata & Big sagebrush & $\mathrm{N}, \mathrm{R}, \mathrm{PS}$ & $\mathrm{X}$ & $\mathrm{X}$ & $\mathrm{X}$ & $\mathrm{X}$ & $\mathrm{X}$ & $\mathrm{X}$ & $\mathrm{X}$ & $\mathrm{X}$ & $\mathrm{X}$ \\
\hline & Chrysothamnus nauseosus & Gray rabbitbrush & $\mathrm{N}, \mathrm{R}, \mathrm{PS}$ & $X$ & $\mathrm{X}$ & $X$ & $X$ & $\mathrm{X}$ & $X$ & $\mathrm{X}$ & $X$ & $\mathrm{X}$ \\
\hline & Chrysothamnus viscidiflorus & Green rabbitbrush & $\mathrm{N}, \mathrm{PS}$ & & & $\mathrm{X}$ & & & & & & \\
\hline & Conyza canadensis & Horseweed & $\mathrm{N}, \mathrm{AF}$ & & & $\mathrm{X}$ & & & & & & \\
\hline & Erigeron spp. & Fleabane species & $\mathrm{N}, \mathrm{PF}$ & & & & & & & $X$ & $X$ & \\
\hline & Lactuca serriola & Prickly lettuce & $\mathrm{I}, \mathrm{AF}$ & $\mathrm{X}$ & $X$ & $X$ & $X$ & $\mathrm{X}$ & & & $X$ & $X$ \\
\hline & Machaeranthera canescens & Hoary aster & $\mathrm{N}, \mathrm{B} / \mathrm{PF}$ & & $\mathrm{X}$ & $X$ & $X$ & $\mathrm{X}$ & $X$ & & $X$ & $X$ \\
\hline & Tragopogon dubius & Yellow salsify & $\mathrm{I}, \mathrm{AF}$ & & $\mathrm{X}$ & $X$ & $\mathrm{X}$ & $\mathrm{X}$ & $\mathrm{X}$ & & & $\mathrm{X}$ \\
\hline Convolvulaceae & Convolvulus arvensis & Field bindweed & $\mathrm{I}, \mathrm{PF}$ & & $\mathrm{X}$ & $X$ & & & & & & \\
\hline Geraniaceae & Erodium cicutarium & Storksbill & $\mathrm{I}, \mathrm{AF}$ & $X$ & $X$ & $X$ & $\mathrm{X}$ & $\mathrm{X}$ & $X$ & $\mathrm{X}$ & $X$ & $\mathrm{X}$ \\
\hline
\end{tabular}


Table 4.5. Plant Species Observed on the Prototype Hanford Barrier in Previous Years ${ }^{(a)}$ (3 pages)

\begin{tabular}{|c|c|c|c|c|c|c|c|c|c|c|c|c|}
\hline \multicolumn{2}{|c|}{ Scientific Name } & \multirow[b]{2}{*}{ Common Name } & \multirow[b]{2}{*}{$\begin{array}{c}\text { Species } \\
\text { Type }\end{array}$} & \multicolumn{9}{|c|}{ Presence (WY) } \\
\hline Family & Species & & & 농 & ஜே & ลิ & \& & ఫิ & 홍 & ชิ & ชิ & ষั \\
\hline Hydrophyllaceae & Phacelia linearis & Threadleaf scorpionweed & $\mathrm{N}, \mathrm{AF}$ & $X$ & & & & & & & & \\
\hline Lamiaceae & Agastache occidentalis & Western horsemint & $\mathrm{N}, \mathrm{PF}$ & & & & $X$ & & & & & \\
\hline \multirow{4}{*}{ Leguminosae } & Astragalus spp. & Milkvetch & $\mathrm{N}, \mathrm{PF}$ & & & $X$ & $\mathrm{X}$ & $X$ & $X$ & & & \\
\hline & Astragalus caricinus & Buckwheat milkvetch & $\mathrm{N}, \mathrm{PF}$ & & & & & $X$ & & & & \\
\hline & Lupinus pusillus & Low lupine & $\mathrm{N}, \mathrm{AF}$ & & & $\mathrm{X}$ & & & & & & \\
\hline & Melilotus alba & Sweetclover & $\mathrm{I}, \mathrm{AF}$ & & $X$ & $X$ & $\mathrm{X}$ & $X$ & $X$ & & & \\
\hline Malvaceae & Sphaeralcea munroana & Munro's globemallow & $\mathrm{N}, \mathrm{PF}$ & & $X$ & $X$ & $X$ & $X$ & $\mathrm{X}$ & & $\mathrm{X}$ & $\mathrm{X}$ \\
\hline Onagraceae & Epilobium paniculatum & Tall willowherb & $\mathrm{N}, \mathrm{AF}$ & & $\mathrm{X}$ & $X$ & $\mathrm{X}$ & $\mathrm{X}$ & $X$ & & & \\
\hline \multirow{13}{*}{ Poaceae } & Agropyron cristatum & Crested wheatgrass & I, PG & & $X$ & $X$ & $\mathrm{X}$ & & & & & \\
\hline & Agropyron dasytachyum & Thickspike wheatgrass & $\mathrm{N}, \mathrm{R}, \mathrm{PG}$ & $X$ & $X$ & $X$ & & & & & & \\
\hline & Agropyron intermedium & Intermediate wheatgrass & $\mathrm{I}, \mathrm{PG}$ & & $\mathrm{X}$ & $X$ & & $X$ & $X$ & $X$ & $X$ & \\
\hline & Bromus tectorum & Cheatgrass & $\mathrm{I}, \mathrm{AG}$ & & $\mathrm{X}$ & $\mathrm{X}$ & $\mathrm{X}$ & $X$ & $X$ & $X$ & $\mathrm{X}$ & $\mathrm{X}$ \\
\hline & Festuca octoflora & Sixweeks fescue & $\mathrm{N}, \mathrm{AG}$ & & & & & & $X$ & $X$ & & $\mathrm{X}$ \\
\hline & Oryzopsis hymenoides & Indian ricegrass & $\mathrm{N}, \mathrm{R}, \mathrm{PG}$ & $\mathrm{X}$ & $\mathrm{X}$ & $X$ & & & $X$ & & & \\
\hline & Poa ampla & Sherman's big bluegrass & $\mathrm{R}, \mathrm{PG}$ & $\mathrm{X}$ & $X$ & $X$ & $\mathrm{X}$ & $X$ & $X$ & $X$ & $X$ & \\
\hline & Poa bulbosa & Bulbous bluegrass & $\mathrm{I}, \mathrm{PG}$ & $\mathrm{X}$ & $\mathrm{X}$ & $\mathrm{X}$ & $\mathrm{X}$ & $X$ & $\mathrm{X}$ & $X$ & $\mathrm{X}$ & $\mathrm{X}$ \\
\hline & Poa sandbergii & Sandberg's bluegrass & $\mathrm{N}, \mathrm{R}, \mathrm{PG}$ & $\mathrm{X}$ & $\mathrm{X}$ & $X$ & $X$ & $X$ & $\mathrm{X}$ & $X$ & $X$ & $\mathrm{X}$ \\
\hline & Pseudoroegneria spicata & Bluebunch wheatgrass & $\mathrm{N}, \mathrm{R}, \mathrm{PG}$ & $\mathrm{X}$ & $\mathrm{X}$ & $X$ & & $X$ & $X$ & $X$ & $X$ & $X$ \\
\hline & Sitanion hystrix & Bottlebrush squirreltail & $\mathrm{N}, \mathrm{R}, \mathrm{PG}$ & $X$ & & & & $\mathrm{X}$ & & & & \\
\hline & Stipa comata & Needle-and-thread grass & $\mathrm{N}, \mathrm{R}, \mathrm{PG}$ & $X$ & & $X$ & & & & & & \\
\hline & Triticum aestivum & Wheat & $\mathrm{I}, \mathrm{AG}$ & $X$ & & & & & & & & \\
\hline Verbenaceae & Verbena bracteata & Bracted verbena & $\mathrm{N}, \mathrm{PF}$ & & $X$ & $\mathrm{X}$ & & & & & & \\
\hline & & Number of Species Present: & & 23 & 27 & 35 & 22 & 26 & 22 & 14 & 17 & 14 \\
\hline
\end{tabular}


Notes for Table 4.5

\begin{tabular}{|llllll|}
\hline $\mathrm{AF}=$ annual forb. & $\mathrm{I}=$ invasive species. & $\mathrm{PG}=$ perennial grass. & $\mathrm{R}$ \\
$\mathrm{AG}=$ annual grass. & $\mathrm{N}=$ native species. & $\mathrm{PS}=$ pecies \\
$\mathrm{B}=$ biennial species. & $\mathrm{PF}=$ perennial forb. & & hydroseeded/revegetated. \\
\hline
\end{tabular}




\subsection{Summary}

The prototype barrier continues to show a relatively high coverage of native plants on the barrier surface 9 years after the initial revegetation effort. The species diversity of the vegetative community of the Prototype Hanford Barrier has stabilized over the past several years. Twelve of 17 species present in 2003 also were present in 2004. Two additional species, six-weeks fescue (Festuca octoflora) and yellow salsify (Tragopogon dubious), were encountered in 2004 and not recorded the previous year. Minor changes in species composition are anticipated from year to year because of variation in annual rainfall, seasonal temperatures, and the time of the season when surveys are conducted.

Canopy cover of shrubs and grasses in both the formerly irrigated and non-irrigated sections of the barrier remained relatively the same between 2003 and 2004. The amount of litter in the formerly irrigated and non-irrigated sections of the barrier surface increased between 2003 and 2004, partly because of the presence of wind-blown tumbleweeds.

Recruitment of sagebrush seedlings was evident on the barrier surface. Many of the previous year's seedlings have become established as juveniles, and further recruitment of seedlings continues to be evident. There was no evidence of recruitment by gray rabbitbrush, which was sparse on the barrier surface. Most of the remaining rabbitbrush appeared moribund, as they had very little vegetative matter from this year's growth, and their stems were extremely dry and brittle.

Quantification of shrub survivorship was not performed in 2004. The actual number of individual plants has become less valuable after 9 years of monitoring because mortality is anticipated as part of community stabilization. A qualitative assessment of the shrub population size, canopy cover, and distribution shows evidence of health and stability within the community. Sagebrush on the Prototype Hanford Barrier continue to flourish, as evident by the recruitment of seedlings and the persistence and growth of individual shrubs. Gray rabbitbrush is on the decline as the barrier surface continues to stabilize.

As noted in previous years, sagebrush shrubs along the perimeter of the barrier appear to be more productive in terms of biomass yield than shrubs on the interior of the barrier. The observed differences in plant size and biomass along the eastern and western edges of the barrier may be caused by a combination of physiological and hydrological factors. A variation in growth rate between interior shrubs and those along the perimeter of the barrier is the most likely physiological difference. A difference in growth rate could be the result of reduced competition because plants along the barrier's edges receive competition from only three sides compared to those on the interior, which receive competition from plants from all four sides. The observed difference in the growth rate of perimeter shrubs most likely is compounded with hydrological factors. By nature of their design, the transition zones (silt-loam to side slope) have a smaller water storage capacity than the interior of the barrier. Water-content data obtained at the bottom of the silt-loam layer by the horizontal neutron measurements have shown an annual increase in water content near the edge of this zone in recent years (DOE-RL 1999). With the absence of plants beyond the silt-loam edge, this water would be available entirely to plants at the perimeter, providing more water for uptake and possibly extending the period of water availability, particularly on the western edge, which has a gravel side slope. It is known that the gravel side slopes produce drainage all year, in contrast to the eastern riprap slope, which, because of advective air flow, does not generate any drainage in the summer. This observation supports the presence of more available water in the siltloam-gravel transition zone than in the silt-loam-riprap zone at the eastern side. This would suggest more available water along the western edge and somewhat larger plants along that boundary. 
The western and northern side slopes of the barrier showed less vegetated cover than the barrier surface, but showed higher species diversity. The relatively higher species diversity of the side slopes may have been caused by differences in soil substrate between the barrier surface and the side slopes, the influence of windblown soil and seeds from adjacent land, or the lack of shrubs competing for resources. Fewer species were observed on the barrier side slopes in 2004 than in previous years. 


\subsection{Animal Intrusion}

This section discusses the methodology and the results of examining animal intrusion on the Prototype Hanford Barrier.

\subsection{Methodology}

The barrier surface was examined for evidence of use and intrusion (burrowing) by insects and small mammals on April 23, 2004. Indications of animal use included direct observation and presence of droppings, tracks, nests, burrows, holes, or resting spots.

\subsection{Results}

Animal use of the Prototype Hanford Barrier was evident and widespread. Cottontail rabbit (Sylvilagus nuttallii) use, indicated by the presence of droppings, was evident throughout the formerly irrigated and non-irrigated portions of the site. Tracks observed on the barrier surface included those of beetles and mice.

Numerous small holes were observed on the barrier surface. These holes, dug by insects and small mammals, were most prevalent in disturbed soils associated with the concrete tile walkway, monitoring equipment, and partially buried plywood. However, unlike previous years, these holes were also prevalent in the interior grids of the barrier surface and were not associated with previous soil disturbance. Most holes ranged in size from 1 to $5 \mathrm{~cm}$ wide ( $\sim 0.4$ to $2 \mathrm{in}$.) and typically up to $5 \mathrm{~cm}$ ( $\sim 2$ in.) deep. A few holes were closer to $15 \mathrm{~cm}$ (6 in.) in depth. Larger depressions were also present in the eastern and southeastern portions of the barrier. These depressions may have been the result of surface soil subsidence, erosion, or a combination of erosion and mammal activity.

Some use by ants was evident in the non-irrigated portion of the barrier surface. Darkling beetles (Eleodes spp.) were also observed actively excavating and using shallow surface burrows in both the formerly irrigated and non-irrigated portions of the barrier.

\subsection{Summary}

Use of the barrier surface by insects (darkling beetles and ants) and small mammals (mice and rabbits) was evident at the time of the survey. Active ant mounds were observed on the northern and western slopes of the barrier. Burrowing by small mammals was more prevalent on the fine-grained soils associated with the northern slope than on the coarse soils of the western slope. The small mammal burrowing on the top and sides of the barrier appears to be associated with finer-grained and disturbed soils. Small mammal burrowing on the barrier surface has become more prevalent in recent years, which may indicate that the restored barrier surface is beginning to function as a recovering ecosystem. 


\subsection{References}

42 USC 9601. Comprehensive Environmental Response, Compensation, and Liability Act of 1980, et seq.

Daubenmire R. 1959. "A Canopy-Coverage Method of Vegetational Analysis.” Northwest Science, 33:43-64.

Fluor Hanford, Inc. 2003. 200-BP-1 Prototype Hanford Barrier Annual Monitoring Report for Fiscal Year 2002. CP-14873, Rev. 0, Richland, WA.

Hook, W.R., N.J. Livingston, Z.J. Sun, P.B. Hook. 1992. Remote Diode Shorting Improves Measurement of Soil-Water by Time Domain Reflectometry. Soil Sci. Soc. Am. J. 56 (5): 1384-1391.

Pacific Northwest Laboratory (PNL). 1995. Procedures for Routine Maintenance and Calibration of Dosing Siphons at the Prototype Surface Barrier. PNL-PSB-4.0, Richland, WA.

Pacific Northwest National Laboratory (PNNL). 1995. Procedure for Measuring Soil Moisture Using the Neutron Probe in the Neutron Probe Access Tube Vertical and Horizontal Arrays. PNNL-PSB-10.0, Richland, WA.

Pacific Northwest National Laboratory (PNNL). 1999. Measuring Soil Water Content With the Moisture Point Time Domain Reflectometry System. PNL-PSB-7.0, Richland, WA.

Pacific Northwest National Laboratory (PNNL). 2004. Hanford Site Climatological Data Summary 2003 with Historical Data. PNNL-14616, Richland, WA.

U.S. Department of Energy-Richland Operations (DOE-RL). 1999. 200-BP-1 Prototype Barrier

Treatability Test Report, Rev. 0, DOE-RL-99-11, Richland, WA. 


\section{Appendix A}

Water Content, Water Balance Summary, and Elevational Measurements for the Prototype Hanford Barrier, 2004 


\section{Appendix A: Water Content, Water Balance Summary, and Elevational Measurements for the Prototype Hanford Barrier, 2004}

Table A.1. Neutron Probe-Measured Water Contents $\left(\mathrm{m}^{3} \mathrm{~m}^{-3}\right)$ for Horizontal Neutron Tubes AA1 Through AA8 at the Bottom of the Lilt Loam Layer of the Prototype Hanford Barrier; Measurements in FY 2003 Through FY 2004.

Table A.2. Neutron Probe-Measured Water Contents $\left(\mathrm{m}^{3} \mathrm{~m}^{-3}\right)$ for Horizontal Neutron Tubes BA1 Through BA6 Under the Asphalt Layer of the Prototype Hanford Barrier; Measurements on March 28, 1995, and April 04, 2004.

Table A.3. Water Balance Summary for the Prototype Hanford Barrier, November 1994 Through August 2003

Table A.4. Prototype Hanford Barrier Surface Elevations (in Meters Above Mean Sea Level) on May 14, 2004. Locations Represent Distance in Meters From Stake 1,1 (Figure 1).

Table A.5. Elevations and Elevation Changes, in Meters, of Settlement Gauges from December 1994

Table A.6. Prototype Hanford Barrier Creep Gauge Locations and Elevations (in Meters Above Mean Sea Level) with Differences Between December 1994 and May 2004.

Table A.7. Prototype Hanford Barrier New Creep Gauge Locations and Elevations (in Meters Above Mean Sea Level) with Differences Between May 2000 and May 2004. 
Table A.1. Neutron Probe-Measured Water Contents $\left(\mathrm{m}^{3} \mathrm{~m}^{-3}\right)$ for Horizontal Neutron Tubes AA1 Through AA8 at Bottom of the Silt Loam Layer of the Prototype Hanford Barrier; Measurements in FY 2003 Through FY 2004 (9 pages).

\begin{tabular}{|c|c|c|c|c|c|c|c|c|c|c|c|}
\hline Date & $\mathrm{x}(\mathrm{m})$ & AA1 & AA2 & AA3 & AA4 & Date & $\mathbf{x}(\mathrm{m})$ & AA1 & AA2 & AA3 & AA4 \\
\hline 10 -Oct-02 & -16 & 0.0796258 & 0.0779833 & 0.0797459 & 0.0790137 & 10 -Oct-02 & 13 & 0.07872 & 0.0782466 & 0.0776383 & 0.0767755 \\
\hline $10-$ Oct- 02 & -15 & 0.0783855 & 0.0770552 & 0.0788527 & 0.0795623 & 10 -Oct-02 & 14 & 0.0788877 & 0.0789157 & 0.0770483 & 0.0772057 \\
\hline 10 -Oct-02 & -14 & 0.0797247 & 0.0780802 & 0.0781356 & 0.0799301 & $10-$ Oct-02 & 15 & 0.0778175 & 0.0775901 & 0.0768572 & 0.0771167 \\
\hline $10-$ Oct-02 & -13 & 0.0805206 & 0.0790418 & 0.0776934 & 0.0795482 & $10-$ Oct-02 & 16 & 0.0683538 & 0.0706028 & 0.0721986 & 0.0679186 \\
\hline $10-$-Oct-02 & -12 & 0.0783925 & 0.0798592 & 0.0774526 & 0.079161 & 03-Dec-02 & -16 & 0.0794494 & 0.0781149 & 0.0800294 & 0.0791962 \\
\hline $10-$ Oct- 02 & -11 & 0.0805706 & 0.0780248 & 0.0772605 & 0.0791962 & $03-$ Dec-02 & -15 & 0.0780941 & 0.077652 & 0.0790979 & 0.0797955 \\
\hline $10-$ Oct-02 & -10 & 0.0808713 & 0.0780595 & 0.0781842 & 0.0796117 & 03-Dec-02 & -14 & 0.0802782 & 0.0778382 & 0.0796753 & 0.0801857 \\
\hline 10 -Oct-02 & -9 & 0.0788807 & 0.0778106 & 0.0778451 & 0.0794072 & 03-Dec-02 & -13 & 0.0798521 & 0.0780456 & 0.079126 & 0.0796965 \\
\hline $10-$ Oct-02 & -8 & 0.0779695 & 0.0785735 & 0.0783369 & 0.0786223 & 03-Dec-02 & -12 & 0.0792524 & 0.0791751 & 0.0776589 & 0.0791962 \\
\hline $10-$ Oct-02 & -7 & 0.0797318 & 0.079161 & 0.0794283 & 0.0799868 & 03-Dec-02 & -11 & 0.0795905 & 0.0775694 & 0.0780941 & 0.0799797 \\
\hline 10 -Oct-02 & -6 & 0.0799513 & 0.0795552 & 0.0792102 & 0.0781842 & 03-Dec-02 & -10 & 0.0784829 & 0.0779557 & 0.078699 & 0.0786711 \\
\hline $10-$-Oct- 02 & -5 & 0.0794847 & 0.079154 & 0.0783786 & 0.0782327 & 03-Dec-02 & -9 & 0.0780318 & 0.0768368 & 0.0774732 & 0.0792524 \\
\hline $10-$-Oct-02 & -4 & 0.0793086 & 0.0790839 & 0.0779488 & 0.0787479 & 03-Dec-02 & -8 & 0.0784133 & 0.077783 & 0.0789367 & 0.0794001 \\
\hline $10-$ Oct-02 & -3 & 0.0806278 & 0.0787968 & 0.0789717 & 0.0818963 & 03-Dec-02 & -7 & 0.0796258 & 0.078462 & 0.0788038 & 0.0789507 \\
\hline $10-$ Oct-02 & 3 & 0.0785665 & 0.0780318 & 0.0774732 & 0.0785456 & 03-Dec-02 & -6 & 0.0794283 & 0.0799159 & 0.079126 & 0.079126 \\
\hline $10-$ Oct- 02 & 4 & 0.0785038 & 0.077535 & 0.0785108 & 0.077377 & 03-Dec-02 & -5 & 0.0794917 & 0.0797672 & 0.0780456 & 0.0790979 \\
\hline $10-$ Oct-02 & 5 & 0.079154 & 0.0786292 & 0.0787758 & 0.0772879 & 03-Dec-02 & -4 & 0.0801288 & 0.0797247 & 0.077281 & 0.0799726 \\
\hline 10 -Oct-02 & 6 & 0.0784829 & 0.0786781 & 0.0786362 & 0.0777141 & 03-Dec-02 & -3 & 0.0813967 & 0.0785874 & 0.0789437 & 0.0828902 \\
\hline 10 -Oct- 02 & 7 & 0.0770893 & 0.0776176 & 0.0770552 & 0.0781218 & 03-Dec-02 & 3 & 0.0773222 & 0.0788527 & 0.0773976 & 0.0793016 \\
\hline $10-$ Oct- 02 & 8 & 0.0782466 & 0.077535 & 0.075902 & 0.0778382 & 03-Dec-02 & 4 & 0.0787549 & 0.0778382 & 0.0787619 & 0.0783091 \\
\hline 10 -Oct-02 & 9 & 0.0789717 & 0.0789997 & 0.0787479 & 0.0781356 & 03-Dec-02 & 5 & 0.0785665 & 0.0778313 & 0.0780595 & 0.0777209 \\
\hline 10 -Oct- 02 & 10 & 0.0795693 & 0.0778935 & 0.0759222 & 0.078706 & 03-Dec-02 & 6 & 0.0787479 & 0.0785317 & 0.0777347 & 0.0774801 \\
\hline 10 -Oct-02 & 11 & 0.0789367 & 0.0777003 & 0.0767074 & 0.0783299 & 03-Dec-02 & 7 & 0.0785526 & 0.0784342 & 0.0773702 & 0.0793368 \\
\hline $10-$ Oct-02 & 12 & 0.0783299 & 0.077329 & 0.0771851 & 0.077281 & 03-Dec-02 & 8 & 0.0782327 & 0.0777141 & 0.0771099 & 0.079534 \\
\hline $10-$ Oct-02 & -16 & 0.0796258 & 0.0779833 & 0.0797459 & 0.0790137 & $10-$ Oct-02 & 13 & 0.07872 & 0.0782466 & 0.0776383 & 0.0767755 \\
\hline
\end{tabular}


Table A.1. Neutron Probe-Measured Water Contents $\left(\mathrm{m}^{3} \mathrm{~m}^{-3}\right)$ for Horizontal Neutron Tubes AA1 Through AA8 at Bottom of the Silt Loam Layer of the Prototype Hanford Barrier; Measurements in FY 2003 Through FY 2004 (9 pages).

\begin{tabular}{|c|c|c|c|c|c|c|c|c|c|c|c|}
\hline Date & $\mathbf{x}(\mathrm{m})$ & AA1 & AA2 & AA3 & AA4 & Date & $\mathrm{x}(\mathrm{m})$ & AA1 & AA2 & AA3 & AA4 \\
\hline 03-Dec-02 & 9 & 0.0782605 & 0.0784203 & 0.0777416 & 0.0780941 & 07-Jan-03 & 5 & 0.0788248 & 0.0773496 & 0.077281 & 0.0781703 \\
\hline 03-Dec-02 & 10 & 0.0792383 & 0.0778037 & 0.0760166 & 0.0784273 & 07-Jan-03 & 6 & 0.0793086 & 0.077928 & 0.0778382 & 0.0785595 \\
\hline 03-Dec-02 & 11 & 0.0790979 & 0.0782189 & 0.0775832 & 0.0781703 & 07-Jan-03 & 7 & 0.0780525 & 0.0793508 & 0.0778382 & 0.0781703 \\
\hline 03-Dec-02 & 12 & 0.0795411 & 0.0779903 & 0.0766122 & 0.0780733 & 07-Jan-03 & 8 & 0.079154 & 0.0779626 & 0.0776796 & 0.0793297 \\
\hline 03-Dec-02 & 13 & 0.0795129 & 0.0782327 & 0.0769459 & 0.076653 & 07-Jan-03 & 9 & 0.0864262 & 0.0788597 & 0.0775488 & 0.0793579 \\
\hline 03-Dec-02 & 14 & 0.0790628 & 0.0779142 & 0.0772536 & 0.0763883 & 07-Jan-03 & 10 & 0.0789227 & 0.0785386 & 0.0769459 & 0.078692 \\
\hline 03-Dec-02 & 15 & 0.0788667 & 0.0777003 & 0.0765104 & 0.0783855 & 07-Jan-03 & 11 & 0.0789507 & 0.0783647 & 0.0773633 & 0.0781772 \\
\hline 03-Dec-02 & 16 & 0.0671222 & 0.0705903 & 0.0679548 & 0.0676541 & 07-Jan-03 & 12 & 0.0789507 & 0.0776934 & 0.0764561 & 0.0774526 \\
\hline 07-Jan-03 & -16 & 0.0795623 & 0.0777003 & 0.0798734 & 0.0794494 & 07-Jan-03 & 13 & 0.0779349 & 0.0782397 & 0.0774457 & 0.0773496 \\
\hline 07-Jan-03 & -15 & 0.0787479 & 0.0769937 & 0.0785247 & 0.0790208 & 07-Jan-03 & 14 & 0.0789857 & 0.0780456 & 0.0777899 & 0.0778175 \\
\hline 07-Jan-03 & -14 & 0.0783021 & 0.0774732 & 0.079126 & 0.0789647 & 07-Jan-03 & 15 & 0.0788527 & 0.0779695 & 0.0762326 & 0.0790979 \\
\hline 07-Jan-03 & -13 & 0.0799797 & 0.0788807 & 0.0785108 & 0.0798521 & 07-Jan-03 & 16 & 0.0677382 & 0.0704902 & 0.0708474 & 0.0743298 \\
\hline 07-Jan-03 & -12 & 0.0796117 & 0.079133 & 0.0777692 & 0.079527 & 20 -Feb-03 & -16 & 0.0798026 & 0.0783091 & 0.0798734 & 0.0794494 \\
\hline 07-Jan-03 & -11 & 0.0815629 & 0.079386 & 0.0792102 & 0.0800649 & 20 -Feb-03 & -15 & 0.0792594 & 0.0781842 & 0.0785247 & 0.0790208 \\
\hline 07-Jan-03 & -10 & 0.0796611 & 0.078316 & 0.078205 & 0.0790067 & 20 -Feb-03 & -14 & 0.0797247 & 0.0779211 & 0.079126 & 0.0789647 \\
\hline 07-Jan-03 & -9 & 0.0787339 & 0.0778244 & 0.0780664 & 0.079379 & 20 -Feb-03 & -13 & 0.0807782 & 0.0799797 & 0.0785108 & 0.0798521 \\
\hline 07-Jan-03 & -8 & 0.0779626 & 0.0770893 & 0.0790909 & 0.0793931 & 20-Feb-03 & -12 & 0.0802711 & 0.0821509 & 0.0777692 & 0.079527 \\
\hline 07-Jan-03 & -7 & 0.0806851 & 0.0788387 & 0.0790278 & 0.0798167 & 20 -Feb-03 & -11 & 0.0806207 & 0.0797672 & 0.0792102 & 0.0800649 \\
\hline 07-Jan-03 & -6 & 0.0788108 & 0.0791119 & 0.0790278 & 0.0792102 & 20 -Feb-03 & -10 & 0.0801004 & 0.0784968 & 0.078205 & 0.0790067 \\
\hline 07-Jan-03 & -5 & 0.0801857 & 0.0790067 & 0.0780733 & 0.0795552 & $20-F e b-03$ & -9 & 0.0789227 & 0.0787758 & 0.0780664 & 0.079379 \\
\hline 07-Jan-03 & -4 & 0.0787339 & 0.0803637 & 0.0781218 & 0.0798734 & 20-Feb-03 & -8 & 0.0794917 & 0.0776107 & 0.0790909 & 0.0793931 \\
\hline 07-Jan-03 & -3 & 0.0799371 & 0.0799159 & 0.0797459 & 0.0814689 & $20-F e b-03$ & -7 & 0.0799868 & 0.079126 & 0.0790278 & 0.0798167 \\
\hline 07-Jan-03 & 3 & 0.0786851 & 0.077783 & 0.0780179 & 0.0782813 & $20-F e b-03$ & -6 & 0.0824868 & 0.0786711 & 0.0790278 & 0.0792102 \\
\hline 07-Jan-03 & 4 & 0.0786153 & 0.078101 & 0.0786641 & 0.0806994 & 20-Feb-03 & -5 & 0.0806493 & 0.0809503 & 0.0780733 & 0.0795552 \\
\hline 03-Dec-02 & 9 & 0.0782605 & 0.0784203 & 0.0777416 & 0.0780941 & 07-Jan-03 & 5 & 0.0788248 & 0.0773496 & 0.077281 & 0.0781703 \\
\hline
\end{tabular}


Table A.1. Neutron Probe-Measured Water Contents $\left(\mathrm{m}^{3} \mathrm{~m}^{-3}\right)$ for Horizontal Neutron Tubes AA1 Through AA8 at Bottom of the Silt Loam Layer of the Prototype Hanford Barrier; Measurements in FY 2003 Through FY 2004 (9 pages).

\begin{tabular}{|c|c|c|c|c|c|c|c|c|c|c|c|}
\hline Date & $\mathrm{x}(\mathrm{m})$ & AA1 & AA2 & AA3 & AA4 & Date & $\mathbf{x}(\mathrm{m})$ & AA1 & AA2 & AA3 & AA4 \\
\hline 20 -Feb-03 & -4 & 0.0811804 & 0.0810293 & 0.0781218 & 0.0798734 & 17-Apr-03 & -8 & 0.0805564 & 0.0800152 & 0.0798167 & 0.0821582 \\
\hline $20-$ Feb-03 & -3 & 0.0818891 & 0.0805992 & 0.0799513 & 0.0793931 & $17-A p r-03$ & -7 & 0.0821072 & 0.0802924 & 0.0797884 & 0.0812668 \\
\hline 20 -Feb-03 & 3 & 0.079161 & 0.0790909 & 0.0797742 & 0.0809359 & 17-Apr-03 & -6 & 0.0836805 & 0.0819108 & 0.0796611 & 0.0822311 \\
\hline 20 -Feb-03 & 4 & 0.0798167 & 0.0786781 & 0.0779211 & 0.0794283 & $17-A p r-03$ & -5 & 0.0822895 & 0.0827139 & 0.0803851 & 0.0814833 \\
\hline $20-$ Feb-03 & 5 & 0.0798804 & 0.079147 & 0.0789787 & 0.0794072 & $17-A p r-03$ & -4 & 0.0816352 & 0.0833177 & 0.0800649 & 0.0797601 \\
\hline $20-$ Feb-03 & 6 & 0.0806636 & 0.0789157 & 0.0772947 & 0.0807853 & $17-A p r-03$ & -3 & 0.0850725 & 0.0828755 & 0.0798238 & 0.0840748 \\
\hline 20 -Feb-03 & 7 & 0.0788877 & 0.0789087 & 0.0792946 & 0.0817149 & 17-Apr-03 & 3 & 0.080814 & 0.0807137 & 0.0804992 & 0.0806064 \\
\hline 20 -Feb-03 & 8 & 0.0817439 & 0.078011 & 0.0797389 & 0.0807782 & 17-Apr-03 & 4 & 0.0815267 & 0.0799584 & 0.0809862 & 0.0816859 \\
\hline $20-$ Feb-03 & 9 & 0.0810221 & 0.079379 & 0.0782397 & 0.0803708 & 17-Apr-03 & 5 & 0.0816715 & 0.079838 & 0.0790348 & 0.0810293 \\
\hline $20-$ Feb-03 & 10 & 0.0810149 & 0.0786223 & 0.0794776 & 0.0798592 & 17-Apr-03 & 6 & 0.0812308 & 0.0805921 & 0.0797035 & 0.0810006 \\
\hline $20-$ Feb- 03 & 11 & 0.0802996 & 0.0787968 & 0.0785735 & 0.0803494 & 17-Apr-03 & 7 & 0.0797884 & 0.0811516 & 0.0789647 & 0.0822384 \\
\hline 20-Feb-03 & 12 & 0.0799513 & 0.0784412 & 0.0777692 & 0.081094 & 17-Apr-03 & 8 & 0.0831774 & 0.079154 & 0.0817657 & 0.0825087 \\
\hline 20-Feb-03 & 13 & 0.0796187 & 0.0785108 & 0.078706 & 0.0791891 & 17-Apr-03 & 9 & 0.0829049 & 0.0797813 & 0.0826479 & 0.0819326 \\
\hline $20-$ Feb-03 & 14 & 0.0781426 & 0.0800294 & 0.0783994 & 0.0802996 & 17-Apr-03 & 10 & 0.0827066 & 0.0791189 & 0.0796258 & 0.0813101 \\
\hline $20-$ Feb-03 & 15 & 0.0787968 & 0.0798734 & 0.0719493 & 0.0667659 & 17-Apr-03 & 11 & 0.0819981 & 0.080857 & 0.0818237 & 0.0811372 \\
\hline $20-$ Feb- 03 & 16 & 0.0686697 & 0.0711623 & 0.0708474 & 0.0743298 & 17-Apr-03 & 12 & 0.0804136 & 0.0803637 & 0.0797035 & 0.0813389 \\
\hline 17-Apr-03 & -16 & 0.0815918 & 0.0799371 & 0.0807638 & 0.0812452 & 17-Apr-03 & 13 & 0.081166 & 0.080857 & 0.0794213 & 0.0786362 \\
\hline 17-Apr-03 & -15 & 0.0802996 & 0.0796682 & 0.0825087 & 0.081831 & 17-Apr-03 & 14 & 0.0796329 & 0.0816497 & 0.0805421 & 0.0807209 \\
\hline 17-Apr-03 & -14 & 0.0806708 & 0.0793368 & 0.0807352 & 0.0805635 & 17-Apr-03 & 15 & 0.0793438 & 0.0806708 & 0.0800791 & 0.0817947 \\
\hline 17-Apr-03 & -13 & 0.0810868 & 0.0811804 & 0.0803209 & 0.0814255 & 17-Apr-03 & 16 & 0.0690055 & 0.0725066 & 0.0752385 & 0.0698615 \\
\hline 17-Apr-03 & -12 & 0.0830152 & 0.0823771 & 0.0794565 & 0.0822238 & 16-May-03 & -16 & 0.0812164 & 0.0801786 & 0.0810221 & 0.0806421 \\
\hline 17-Apr-03 & -11 & 0.0829269 & 0.0802996 & 0.0798026 & 0.0830815 & 16-May-03 & -15 & 0.0809359 & 0.0789157 & 0.0812956 & 0.0824648 \\
\hline $17-A p r-03$ & -10 & 0.0826552 & 0.0801999 & 0.0800081 & 0.0824941 & 16-May-03 & -14 & 0.0809575 & 0.0792664 & 0.0802568 & 0.0807782 \\
\hline 17-Apr-03 & -9 & 0.0806922 & 0.0792313 & 0.0785665 & 0.0819763 & 16-Маy-03 & -13 & 0.0828461 & 0.0822603 & 0.0809359 & 0.0833398 \\
\hline $20-$ Feb-03 & -4 & 0.0811804 & 0.0810293 & 0.0781218 & 0.0798734 & 17-Apr-03 & -8 & 0.0805564 & 0.0800152 & 0.0798167 & 0.0821582 \\
\hline
\end{tabular}


Table A.1. Neutron Probe-Measured Water Contents $\left(\mathrm{m}^{3} \mathrm{~m}^{-3}\right)$ for Horizontal Neutron Tubes AA1 Through AA8 at Bottom of the Silt Loam Layer of the Prototype Hanford Barrier; Measurements in FY 2003 Through FY 2004 (9 pages).

\begin{tabular}{|c|c|c|c|c|c|c|c|c|c|c|c|}
\hline Date & $\mathbf{x}(\mathrm{m})$ & AA1 & AA2 & AA3 & AA4 & Date & $\mathrm{x}(\mathrm{m})$ & AA1 & AA2 & AA3 & AA4 \\
\hline 03-Dec-02 & 9 & 0.0782605 & 0.0784203 & 0.0777416 & 0.0780941 & 07-Jan-03 & 5 & 0.0788248 & 0.0773496 & 0.077281 & 0.0781703 \\
\hline 03-Dec-02 & 10 & 0.0792383 & 0.0778037 & 0.0760166 & 0.0784273 & 07-Jan-03 & 6 & 0.0793086 & 0.077928 & 0.0778382 & 0.0785595 \\
\hline 03-Dec-02 & 11 & 0.0790979 & 0.0782189 & 0.0775832 & 0.0781703 & 07-Jan-03 & 7 & 0.0780525 & 0.0793508 & 0.0778382 & 0.0781703 \\
\hline 03-Dec-02 & 12 & 0.0795411 & 0.0779903 & 0.0766122 & 0.0780733 & 07-Jan-03 & 8 & 0.079154 & 0.0779626 & 0.0776796 & 0.0793297 \\
\hline 03-Dec-02 & 13 & 0.0795129 & 0.0782327 & 0.0769459 & 0.076653 & 07-Jan-03 & 9 & 0.0864262 & 0.0788597 & 0.0775488 & 0.0793579 \\
\hline 03-Dec-02 & 14 & 0.0790628 & 0.0779142 & 0.0772536 & 0.0763883 & 07-Jan-03 & 10 & 0.0789227 & 0.0785386 & 0.0769459 & 0.078692 \\
\hline 03-Dec-02 & 15 & 0.0788667 & 0.0777003 & 0.0765104 & 0.0783855 & 07-Jan-03 & 11 & 0.0789507 & 0.0783647 & 0.0773633 & 0.0781772 \\
\hline 03-Dec-02 & 16 & 0.0671222 & 0.0705903 & 0.0679548 & 0.0676541 & 07-Jan-03 & 12 & 0.0789507 & 0.0776934 & 0.0764561 & 0.0774526 \\
\hline 07-Jan-03 & -16 & 0.0795623 & 0.0777003 & 0.0798734 & 0.0794494 & 07-Jan-03 & 13 & 0.0779349 & 0.0782397 & 0.0774457 & 0.0773496 \\
\hline 07-Jan-03 & -15 & 0.0787479 & 0.0769937 & 0.0785247 & 0.0790208 & 07-Jan-03 & 14 & 0.0789857 & 0.0780456 & 0.0777899 & 0.0778175 \\
\hline 07-Jan-03 & -14 & 0.0783021 & 0.0774732 & 0.079126 & 0.0789647 & 07-Jan-03 & 15 & 0.0788527 & 0.0779695 & 0.0762326 & 0.0790979 \\
\hline 07-Jan-03 & -13 & 0.0799797 & 0.0788807 & 0.0785108 & 0.0798521 & 07-Jan-03 & 16 & 0.0677382 & 0.0704902 & 0.0708474 & 0.0743298 \\
\hline 07-Jan-03 & -12 & 0.0796117 & 0.079133 & 0.0777692 & 0.079527 & $20-F e b-03$ & -16 & 0.0798026 & 0.0783091 & 0.0798734 & 0.0794494 \\
\hline 07-Jan-03 & -11 & 0.0815629 & 0.079386 & 0.0792102 & 0.0800649 & $20-F e b-03$ & -15 & 0.0792594 & 0.0781842 & 0.0785247 & 0.0790208 \\
\hline 07-Jan-03 & -10 & 0.0796611 & 0.078316 & 0.078205 & 0.0790067 & $20-$ Feb-03 & -14 & 0.0797247 & 0.0779211 & 0.079126 & 0.0789647 \\
\hline 07-Jan-03 & -9 & 0.0787339 & 0.0778244 & 0.0780664 & 0.079379 & $20-$ Feb-03 & -13 & 0.0807782 & 0.0799797 & 0.0785108 & 0.0798521 \\
\hline 07-Jan-03 & -8 & 0.0779626 & 0.0770893 & 0.0790909 & 0.0793931 & $20-$ Feb-03 & -12 & 0.0802711 & 0.0821509 & 0.0777692 & 0.079527 \\
\hline 07-Jan-03 & -7 & 0.0806851 & 0.0788387 & 0.0790278 & 0.0798167 & $20-$ Feb-03 & -11 & 0.0806207 & 0.0797672 & 0.0792102 & 0.0800649 \\
\hline 07-Jan-03 & -6 & 0.0788108 & 0.0791119 & 0.0790278 & 0.0792102 & $20-F e b-03$ & -10 & 0.0801004 & 0.0784968 & 0.078205 & 0.0790067 \\
\hline 07-Jan-03 & -5 & 0.0801857 & 0.0790067 & 0.0780733 & 0.0795552 & 20-Feb-03 & -9 & 0.0789227 & 0.0787758 & 0.0780664 & 0.079379 \\
\hline 07-Jan-03 & -4 & 0.0787339 & 0.0803637 & 0.0781218 & 0.0798734 & 20 -Feb-03 & -8 & 0.0794917 & 0.0776107 & 0.0790909 & 0.0793931 \\
\hline 07-Jan-03 & -3 & 0.0799371 & 0.0799159 & 0.0797459 & 0.0814689 & $20-$ Feb-03 & -7 & 0.0799868 & 0.079126 & 0.0790278 & 0.0798167 \\
\hline 07-Jan-03 & 3 & 0.0786851 & 0.077783 & 0.0780179 & 0.0782813 & 20 -Feb-03 & -6 & 0.0824868 & 0.0786711 & 0.0790278 & 0.0792102 \\
\hline 07-Jan-03 & 4 & 0.0786153 & 0.078101 & 0.0786641 & 0.0806994 & 20-Feb-03 & -5 & 0.0806493 & 0.0809503 & 0.0780733 & 0.0795552 \\
\hline 03-Dec-02 & 9 & 0.0782605 & 0.0784203 & 0.0777416 & 0.0780941 & 07-Jan-03 & 5 & 0.0788248 & 0.0773496 & 0.077281 & 0.0781703 \\
\hline
\end{tabular}


Table A.1. Neutron Probe-Measured Water Contents $\left(\mathrm{m}^{3} \mathrm{~m}^{-3}\right)$ for Horizontal Neutron Tubes AA1 Through AA8 at Bottom of the Silt Loam Layer of the Prototype Hanford Barrier; Measurements in FY 2003 Through FY 2004 (9 pages).

\begin{tabular}{|c|c|c|c|c|c|c|c|c|c|c|c|}
\hline Date & $\mathbf{x}(\mathrm{m})$ & AA1 & AA2 & AA3 & AA4 & Date & $\mathbf{x}(\mathrm{m})$ & AA1 & AA2 & AA3 & AA4 \\
\hline 16-May-03 & -12 & 0.0828387 & 0.0821072 & 0.0795482 & 0.081599 & 18-Jun-03 & 3 & 0.0799371 & 0.0804421 & 0.0806493 & 0.0808211 \\
\hline 16-May-03 & -11 & 0.082802 & 0.0811084 & 0.0815918 & 0.0834138 & 18-Jun-03 & 4 & 0.080001 & 0.0800081 & 0.0813173 & 0.0796894 \\
\hline 16-May-03 & -10 & 0.0819544 & 0.0787479 & 0.0797742 & 0.082802 & 18-Jun-03 & 5 & 0.0819908 & 0.0801786 & 0.0794988 & 0.0806421 \\
\hline 16-Мay-03 & -9 & 0.0811444 & 0.0810221 & 0.079126 & 0.0817149 & 18-Jun-03 & 6 & 0.080814 & 0.0797742 & 0.0792524 & 0.0804493 \\
\hline 16-Мay-03 & -8 & 0.0804849 & 0.0792594 & 0.079838 & 0.0815122 & 18-Jun-03 & 7 & 0.081058 & 0.0810221 & 0.0793227 & 0.0807782 \\
\hline 16-May-03 & -7 & 0.0815629 & 0.0804707 & 0.0797742 & 0.081657 & 18-Jun-03 & 8 & 0.0835915 & 0.0799371 & 0.0796894 & 0.0816497 \\
\hline 16-Мay-03 & -6 & 0.0840823 & 0.0806994 & 0.0785247 & 0.0830005 & 18-Jun-03 & 9 & 0.0822165 & 0.0805064 & 0.0796187 & 0.0813894 \\
\hline 16-May-03 & -5 & 0.0815484 & 0.083266 & 0.0803851 & 0.082399 & 18-Jun-03 & 10 & 0.0823406 & 0.080001 & 0.0789997 & 0.0806922 \\
\hline 16-May-03 & -4 & 0.0819181 & 0.0823406 & 0.0800933 & 0.0806708 & 18-Jun-03 & 11 & 0.0826406 & 0.0796187 & 0.0801217 & 0.0813894 \\
\hline 16-May-03 & -3 & 0.0823114 & 0.0836731 & 0.0804207 & 0.0843512 & 18-Jun-03 & 12 & 0.0809 & 0.0805564 & 0.0792032 & 0.079161 \\
\hline 16-Мay-03 & 3 & 0.0808785 & 0.080143 & 0.0809862 & 0.0804778 & 18-Jun-03 & 13 & 0.080979 & 0.080728 & 0.0784968 & 0.0789647 \\
\hline 16-May-03 & 4 & 0.0827726 & 0.0804778 & 0.0807996 & 0.0814906 & 18-Jun-03 & 14 & 0.0793016 & 0.0824502 & 0.0792735 & 0.0799159 \\
\hline 16-May-03 & 5 & 0.0814472 & 0.080435 & 0.0788527 & 0.0798592 & 18-Jun-03 & 15 & 0.0787549 & 0.0809646 & 0.0774526 & 0.0801572 \\
\hline 16-May-03 & 6 & 0.081375 & 0.0804707 & 0.0790839 & 0.0807925 & 18-Jun-03 & 16 & 0.0696635 & 0.0680936 & 0.0733214 & 0.0671996 \\
\hline 16-Мay-03 & 7 & 0.0808355 & 0.0813606 & 0.0790348 & 0.0833029 & 18-Jun-03 & -16 & 0.0813967 & 0.0800081 & 0.0805635 & 0.0808427 \\
\hline 16-Маy-03 & 8 & 0.083362 & 0.0812308 & 0.0810365 & 0.0822165 & 18-Jun-03 & -15 & 0.0801359 & 0.07872 & 0.0805921 & 0.08186 \\
\hline 16-Мay-03 & 9 & 0.0822822 & 0.0796894 & 0.0817947 & 0.0810077 & 18-Jun-03 & -14 & 0.0811372 & 0.0789017 & 0.0792102 & 0.0817512 \\
\hline 16-Мay-03 & 10 & 0.0823406 & 0.0793368 & 0.0802212 & 0.0810006 & 18-Jun-03 & -13 & 0.0827726 & 0.0810293 & 0.0803708 & 0.083111 \\
\hline 16-Мау-03 & 11 & 0.0829564 & 0.079753 & 0.0823625 & 0.0819036 & 18-Jun-03 & -12 & 0.0822822 & 0.0826259 & 0.0796046 & 0.0809287 \\
\hline 16-May-03 & 12 & 0.081628 & 0.0805492 & 0.0797106 & 0.0811156 & 18-Jun-03 & -11 & 0.0817657 & 0.0810868 & 0.0797035 & 0.0825161 \\
\hline 16-Мay-03 & 13 & 0.0813245 & 0.0803993 & 0.080143 & 0.0796046 & 18-Jun-03 & -10 & 0.081238 & 0.0799939 & 0.0781911 & 0.0819544 \\
\hline 16-Мay-03 & 14 & 0.0786502 & 0.0820781 & 0.0805564 & 0.0811084 & 18-Jun-03 & -9 & 0.0797672 & 0.079647 & 0.0796894 & 0.0812668 \\
\hline 16-May-03 & 15 & 0.0798238 & 0.0810437 & 0.0796965 & 0.081375 & 18-Jun-03 & -8 & 0.0802497 & 0.0794213 & 0.0781149 & 0.0811444 \\
\hline 16-May-03 & 16 & 0.0693737 & 0.0663939 & 0.0722947 & 0.0671043 & 18-Jun-03 & -7 & 0.0819835 & 0.0809718 & 0.0794847 & 0.082326 \\
\hline 16-Мay-03 & -12 & 0.0828387 & 0.0821072 & 0.0795482 & 0.081599 & 18-Jun-03 & 3 & 0.0799371 & 0.0804421 & 0.0806493 & 0.0808211 \\
\hline
\end{tabular}


Table A.1. Neutron Probe-Measured Water Contents $\left(\mathrm{m}^{3} \mathrm{~m}^{-3}\right)$ for Horizontal Neutron Tubes AA1 Through AA8 at Bottom of the Silt Loam Layer of the Prototype Hanford Barrier; Measurements in FY 2003 Through FY 2004 (9 pages).

\begin{tabular}{|c|c|c|c|c|c|c|c|c|c|c|c|}
\hline Date & $\mathbf{x}(\mathrm{m})$ & AA1 & AA2 & AA3 & AA4 & Date & $\mathbf{x}(\mathrm{m})$ & AA1 & AA2 & AA3 & AA4 \\
\hline 18-Jun-03 & -6 & 0.0822384 & 0.0808427 & 0.0807996 & 0.0814544 & 02-Aug-03 & 9 & 0.0821437 & 0.0804778 & 0.0793297 & 0.0810868 \\
\hline 18-Jun-03 & -5 & 0.0816352 & 0.0829416 & 0.0790137 & 0.0827433 & 02-Aug-03 & 10 & 0.0821582 & 0.0797106 & 0.0789577 & 0.0803993 \\
\hline 18-Jun-03 & -4 & 0.0818092 & 0.081831 & 0.0812812 & 0.08113 & 02-Aug-03 & 11 & 0.0824795 & 0.0795411 & 0.0798096 & 0.0813101 \\
\hline 18-Jun-03 & -3 & 0.0815122 & 0.0815122 & 0.0898657 & 0.0839258 & 02-Aug-03 & 12 & 0.0807853 & 0.0803637 & 0.0788597 & 0.0790278 \\
\hline 02-Aug-03 & -16 & 0.0806207 & 0.0786502 & 0.0797177 & 0.0805992 & 02-Aug-03 & 13 & 0.0809 & 0.0803922 & 0.0784481 & 0.0786711 \\
\hline 02-Aug-03 & -15 & 0.0786851 & 0.0777485 & 0.0797389 & 0.0807925 & 02-Aug-03 & 14 & 0.0790067 & 0.0821 & 0.0791049 & 0.0798875 \\
\hline 02-Aug-03 & -14 & 0.0801857 & 0.0783091 & 0.0793931 & 0.0806135 & 02-Aug-03 & 15 & 0.0785247 & 0.0809072 & 0.0772742 & 0.0798096 \\
\hline 02-Aug-03 & -13 & 0.0808068 & 0.079753 & 0.0793086 & 0.0804493 & 02-Aug-03 & 16 & 0.069423 & 0.0678885 & 0.0732305 & 0.067146 \\
\hline 02-Aug-03 & -12 & 0.0804778 & 0.0799939 & 0.0777554 & 0.0809575 & 07-Sep-03 & -16 & 0.0799939 & 0.078699 & 0.0793368 & 0.0796823 \\
\hline 02-Aug-03 & -11 & 0.0817004 & 0.0797035 & 0.0783299 & 0.0817947 & 07-Sep-03 & -15 & 0.0790208 & 0.0772536 & 0.0789787 & 0.0803423 \\
\hline 02-Aug-03 & -10 & 0.0803138 & 0.0789437 & 0.0784133 & 0.0795058 & 07-Sep-03 & -14 & 0.079372 & 0.0773633 & 0.0775282 & 0.0803352 \\
\hline 02-Aug-03 & -9 & 0.0788807 & 0.0776176 & 0.0784412 & 0.0795058 & 07-Sep-03 & -13 & 0.0815267 & 0.079372 & 0.0786502 & 0.0813245 \\
\hline 02-Aug-03 & -8 & 0.0798167 & 0.0792594 & 0.0788877 & 0.0799939 & 07-Sep-03 & -12 & 0.0806493 & 0.0814544 & 0.0785108 & 0.0793086 \\
\hline 02-Aug-03 & -7 & 0.0802639 & 0.0800862 & 0.0802639 & 0.0803138 & 07-Sep-03 & -11 & 0.0803138 & 0.0798521 & 0.0781495 & 0.0810221 \\
\hline 02-Aug-03 & -6 & 0.0811228 & 0.0803708 & 0.0798026 & 0.0804207 & 07-Sep-03 & -10 & 0.0798026 & 0.0786711 & 0.0765171 & 0.0802141 \\
\hline 02-Aug-03 & -5 & 0.08144 & 0.0806851 & 0.0791119 & 0.0804778 & 07-Sep-03 & -9 & 0.0781426 & 0.0785944 & 0.078476 & 0.0795552 \\
\hline 02-Aug-03 & -4 & 0.0804421 & 0.0815195 & 0.0782674 & 0.0802853 & 07-Sep-03 & -8 & 0.0789087 & 0.0783647 & 0.0768777 & 0.0796046 \\
\hline 02-Aug-03 & -3 & 0.0811732 & 0.0799371 & 0.0797601 & 0.0828681 & 07-Sep-03 & -7 & 0.0806708 & 0.0796894 & 0.0779418 & 0.0809646 \\
\hline 02-Aug-03 & 3 & 0.0798026 & 0.080207 & 0.0804564 & 0.0805778 & 07-Sep-03 & -6 & 0.0810149 & 0.0792735 & 0.0792453 & 0.080143 \\
\hline 02-Aug-03 & 4 & 0.0797742 & 0.0799159 & 0.081058 & 0.0795976 & 07-Sep-03 & -5 & 0.0801501 & 0.0816063 & 0.0773153 & 0.0811012 \\
\hline 02-Aug-03 & 5 & 0.081628 & 0.0798521 & 0.0794213 & 0.0804921 & 07-Sep-03 & -4 & 0.0804921 & 0.0806779 & 0.0796965 & 0.0798238 \\
\hline 02-Aug-03 & 6 & 0.0807853 & 0.0797177 & 0.0791119 & 0.0802924 & 07-Sep-03 & -3 & 0.0814472 & 0.0797389 & 0.0881917 & 0.0827873 \\
\hline 02-Aug-03 & 7 & 0.0807209 & 0.0809 & 0.0790768 & 0.0806922 & 07-Sep-03 & 3 & 0.0787549 & 0.0792735 & 0.079161 & 0.0793157 \\
\hline 02-Aug-03 & 8 & 0.083266 & 0.0797601 & 0.079647 & 0.0813533 & 07-Sep-03 & 4 & 0.0787619 & 0.0787479 & 0.079923 & 0.0781634 \\
\hline 18-Jun-03 & -6 & 0.0822384 & 0.0808427 & 0.0807996 & 0.0814544 & 02-Aug-03 & 9 & 0.0821437 & 0.0804778 & 0.0793297 & 0.0810868 \\
\hline
\end{tabular}


Table A.1. Neutron Probe-Measured Water Contents $\left(\mathrm{m}^{3} \mathrm{~m}^{-3}\right)$ for Horizontal Neutron Tubes AA1 Through AA8 at Bottom of the Silt Loam Layer of the Prototype Hanford Barrier; Measurements in FY 2003 Through FY 2004 (9 pages).

\begin{tabular}{|c|c|c|c|c|c|c|c|c|c|c|c|}
\hline Date & $x(m)$ & AA1 & AA2 & AA3 & AA4 & Date & $x(\mathrm{~m})$ & AA1 & AA2 & AA3 & AA4 \\
\hline 07-Sep-03 & 5 & 0.0808427 & 0.0790418 & 0.0779073 & 0.0791821 & 09-Apr-04 & -4 & 0.0814617 & 0.0829784 & 0.0784273 & 0.0794635 \\
\hline 07-Sep-03 & 6 & 0.0795905 & 0.0786362 & 0.0778451 & 0.0787619 & 09-Apr-04 & -3 & 0.0792172 & 0.0796046 & 0.0788038 & 0.0797389 \\
\hline 07-Sep-03 & 7 & 0.0797035 & 0.0798096 & 0.0776038 & 0.0792524 & 09-Apr-04 & 3 & 0.0792172 & 0.0796046 & 0.0788038 & 0.0797389 \\
\hline 07-Sep-03 & 8 & 0.0817657 & 0.0786711 & 0.0779488 & 0.0798946 & 09-Apr-04 & 4 & 0.0811444 & 0.0781911 & 0.0792383 & 0.0798804 \\
\hline 07-Sep-03 & 9 & 0.0808929 & 0.0791962 & 0.0782674 & 0.0802782 & 09-Apr-04 & 5 & 0.0808857 & 0.0799797 & 0.0784273 & 0.0798946 \\
\hline 07-Sep-03 & 10 & 0.0811444 & 0.0785944 & 0.0773976 & 0.079126 & 09-Apr-04 & 6 & 0.079379 & 0.0782327 & 0.0793227 & 0.0798521 \\
\hline 07-Sep-03 & 11 & 0.0814039 & 0.0785526 & 0.0785526 & 0.0802568 & 09-Apr-04 & 7 & 0.0793931 & 0.0806421 & 0.078462 & 0.081094 \\
\hline 07-Sep-03 & 12 & 0.0792946 & 0.0790278 & 0.0781149 & 0.0780456 & 09-Apr-04 & 8 & 0.0832364 & 0.0792664 & 0.0789507 & 0.0815629 \\
\hline 07-Sep-03 & 13 & 0.0796611 & 0.0790278 & 0.0770825 & 0.0778244 & 09-Apr-04 & 9 & 0.0822968 & 0.0798521 & 0.0801572 & 0.0803209 \\
\hline 07-Sep-03 & 14 & 0.0779004 & 0.0807065 & 0.0781842 & 0.0787898 & 09-Apr-04 & 10 & 0.0810006 & 0.0776865 & 0.0790909 & 0.0798804 \\
\hline 07-Sep-03 & 15 & 0.0774182 & 0.0796046 & 0.0761786 & 0.0789157 & 09-Apr-04 & 11 & 0.0818818 & 0.0787898 & 0.0784412 & 0.0813894 \\
\hline 07-Sep-03 & 16 & 0.0685663 & 0.0668726 & 0.0719301 & 0.0661764 & 09-Apr-04 & 12 & 0.0815629 & 0.0795693 & 0.077597 & 0.0814039 \\
\hline 09-Apr-04 & -16 & 0.0803851 & 0.0794072 & 0.0797247 & 0.0822311 & 09-Apr-04 & 13 & 0.0809934 & 0.0794001 & 0.0797459 & 0.0789157 \\
\hline 09-Apr-04 & -15 & 0.079923 & 0.0786292 & 0.0797389 & 0.082049 & 09-Apr-04 & 14 & 0.0790418 & 0.0816859 & 0.0812308 & 0.0815629 \\
\hline 09-Apr-04 & -14 & 0.0799442 & 0.0778727 & 0.0789227 & 0.080814 & 09-Apr-04 & 15 & 0.0794988 & 0.0803352 & 0.0794494 & 0.0815773 \\
\hline 09-Apr-04 & -13 & 0.0806278 & 0.0805635 & 0.0783716 & 0.0820199 & 09-Apr-04 & 16 & 0.0677562 & 0.0697563 & 0.0734125 & 0.0674923 \\
\hline 09-Apr-04 & -12 & 0.082421 & 0.0810365 & 0.0774045 & 0.0816425 & 04-Jul-04 & -16 & 0.0801146 & 0.0790278 & 0.0792102 & 0.0798592 \\
\hline 09-Apr-04 & -11 & 0.0815773 & 0.0793508 & 0.0774388 & 0.0843437 & 04-Jul-04 & -15 & 0.079161 & 0.077535 & 0.0792594 & 0.0804992 \\
\hline 09-Apr-04 & -10 & 0.0806421 & 0.0793016 & 0.0785177 & 0.0824648 & 04-Jul-04 & -14 & 0.0797318 & 0.0777209 & 0.0778382 & 0.0802853 \\
\hline 09-Apr-04 & -9 & 0.0796329 & 0.0792524 & 0.077597 & 0.0825893 & 04-Jul-04 & -13 & 0.0816715 & 0.0795411 & 0.0786083 & 0.0812668 \\
\hline 09-Apr-04 & -8 & 0.0796046 & 0.0792313 & 0.0796258 & 0.0815556 & 04-Jul-04 & -12 & 0.0809359 & 0.0815484 & 0.0788457 & 0.0793649 \\
\hline 09-Apr-04 & -7 & 0.0817077 & 0.0807925 & 0.0797601 & 0.0806564 & 04-Jul-04 & -11 & 0.0803352 & 0.0800862 & 0.0782536 & 0.0810437 \\
\hline 09-Apr-04 & -6 & 0.0830668 & 0.0815918 & 0.0794917 & 0.0806636 & 04-Jul-04 & -10 & 0.0797247 & 0.0789927 & 0.0767959 & 0.0804065 \\
\hline 09-Apr-04 & -5 & 0.0821801 & 0.0832955 & 0.0781218 & 0.0802782 & 04-Jul-04 & -9 & 0.0783925 & 0.0788947 & 0.0787828 & 0.0798734 \\
\hline 07-Sep-03 & 5 & 0.0808427 & 0.0790418 & 0.0779073 & 0.0791821 & 09-Apr-04 & -4 & 0.0814617 & 0.0829784 & 0.0784273 & 0.0794635 \\
\hline
\end{tabular}


Table A.1. Neutron Probe-Measured Water Contents $\left(\mathrm{m}^{3} \mathrm{~m}^{-3}\right)$ for Horizontal Neutron Tubes AA1 Through AA8 at Bottom of the Silt Loam Layer of the Prototype Hanford Barrier; Measurements in FY 2003 Through FY 2004 (9 pages).

\begin{tabular}{|c|c|c|c|c|c|c|c|c|c|c|c|}
\hline Date & $\mathbf{x}(\mathrm{m})$ & AA1 & AA2 & AA3 & AA4 & Date & $x(m)$ & AA1 & AA2 & AA3 & AA4 \\
\hline 04-Jul-04 & -8 & 0.0790979 & 0.078316 & 0.0770278 & 0.0799088 & 04-Sep-04 & -12 & 0.082421 & 0.0810365 & 0.0774045 & 0.0816425 \\
\hline 04-Jul-04 & -7 & 0.0810365 & 0.0798663 & 0.0780179 & 0.0809 & 04-Sep-04 & -11 & 0.0815773 & 0.0793508 & 0.0774388 & 0.0843437 \\
\hline 04-Jul-04 & -6 & 0.0812668 & 0.0793157 & 0.079372 & 0.0800791 & 04-Sep-04 & -10 & 0.0806421 & 0.0793016 & 0.0785177 & 0.0824648 \\
\hline 04-Jul-04 & -5 & 0.080001 & 0.0816715 & 0.0775419 & 0.0812668 & 04-Sep-04 & -9 & 0.0796329 & 0.0792524 & 0.077597 & 0.0825893 \\
\hline 04-Jul-04 & -4 & 0.0807495 & 0.0808642 & 0.0798096 & 0.079923 & 04-Sep-04 & -8 & 0.0796046 & 0.0792313 & 0.0796258 & 0.0815556 \\
\hline 04-Jul-04 & -3 & 0.081505 & 0.0797813 & 0.0884032 & 0.0830005 & 04-Sep-04 & -7 & 0.0817077 & 0.0807925 & 0.0797601 & 0.0806564 \\
\hline 04-Jul-04 & 3 & 0.0789017 & 0.0793086 & 0.0792102 & 0.0796682 & 04-Sep-04 & -6 & 0.0830668 & 0.0815918 & 0.0794917 & 0.0806636 \\
\hline 04-Jul-04 & 4 & 0.0788457 & 0.0787968 & 0.0800223 & 0.0786641 & 04-Sep-04 & -5 & 0.0821801 & 0.0832955 & 0.0781218 & 0.0802782 \\
\hline 04-Jul-04 & 5 & 0.0811084 & 0.079133 & 0.0781703 & 0.0792383 & 04-Sep-04 & -4 & 0.0814617 & 0.0829784 & 0.0784273 & 0.0794635 \\
\hline 04-Jul-04 & 6 & 0.0799655 & 0.0787828 & 0.0780733 & 0.0790768 & 04-Sep-04 & -3 & 0.0843437 & 0.0841196 & 0.0803138 & 0.0833103 \\
\hline 04-Jul-04 & 7 & 0.0796894 & 0.080001 & 0.0777003 & 0.0792383 & 04-Sep-04 & 3 & 0.0792172 & 0.0796046 & 0.0788038 & 0.0797389 \\
\hline 04-Jul-04 & 8 & 0.081628 & 0.0789997 & 0.0782189 & 0.0799868 & 04-Sep-04 & 4 & 0.0811444 & 0.0781911 & 0.0792383 & 0.0798804 \\
\hline 04-Jul-04 & 9 & 0.0810652 & 0.0794494 & 0.078323 & 0.0802497 & 04-Sep-04 & 5 & 0.0808857 & 0.0799797 & 0.0784273 & 0.0798946 \\
\hline 04-Jul-04 & 10 & 0.0813389 & 0.0786711 & 0.0775282 & 0.079154 & 04-Sep-04 & 6 & 0.079379 & 0.0782327 & 0.0793227 & 0.0798521 \\
\hline 04-Jul-04 & 11 & 0.081238 & 0.0788667 & 0.0785874 & 0.0803494 & 04-Sep-04 & 7 & 0.0793931 & 0.0806421 & 0.078462 & 0.081094 \\
\hline 04-Jul-04 & 12 & 0.0794706 & 0.0792032 & 0.0780941 & 0.0783994 & 04-Sep-04 & 8 & 0.0832364 & 0.0792664 & 0.0789507 & 0.0815629 \\
\hline 04-Jul-04 & 13 & 0.0801359 & 0.0790558 & 0.0771577 & 0.0780941 & 04-Sep-04 & 9 & 0.0822968 & 0.0798521 & 0.0801572 & 0.0803209 \\
\hline 04-Jul-04 & 14 & 0.0782119 & 0.0808427 & 0.0784273 & 0.0790698 & 04-Sep-04 & 10 & 0.0810006 & 0.0776865 & 0.0790909 & 0.0798804 \\
\hline 04-Jul-04 & 15 & 0.0774457 & 0.0795482 & 0.07628 & 0.0787619 & 04-Sep-04 & 11 & 0.0818818 & 0.0787898 & 0.0784412 & 0.0813894 \\
\hline 04-Jul-04 & 16 & 0.0686941 & 0.0669854 & 0.072109 & 0.0662997 & 04-Sep-04 & 12 & 0.0815629 & 0.0795693 & 0.077597 & 0.0814039 \\
\hline 04-Sep-04 & -16 & 0.0803851 & 0.0794072 & 0.0797247 & 0.0822311 & 04-Sep-04 & 13 & 0.0809934 & 0.0794001 & 0.0797459 & 0.0789157 \\
\hline 04-Sep-04 & -15 & 0.079923 & 0.0786292 & 0.0797389 & 0.082049 & 04-Sep-04 & 14 & 0.0790418 & 0.0816859 & 0.0812308 & 0.0815629 \\
\hline 04-Sep-04 & -14 & 0.0799442 & 0.0778727 & 0.0789227 & 0.080814 & 04-Sep-04 & 15 & 0.0794988 & 0.0803352 & 0.0794494 & 0.0815773 \\
\hline 04-Sep-04 & -13 & 0.0806278 & 0.0805635 & 0.0783716 & 0.0820199 & 04-Sep-04 & 16 & 0.0677562 & 0.0697563 & 0.0734125 & 0.0674923 \\
\hline 04-Jul-04 & -8 & 0.0790979 & 0.078316 & 0.0770278 & 0.0799088 & 04-Sep-04 & -12 & 0.082421 & 0.0810365 & 0.0774045 & 0.0816425 \\
\hline
\end{tabular}


Table A.2. Neutron Probe-Measured Water Contents $\left(\mathrm{m}^{3} \mathrm{~m}^{-3}\right)$ for Horizontal Neutron Tubes BA1 Through BA6 Under the Asphalt Layer of the Prototype Hanford Barrier; Measurements on March 28, 1995, and April 04, 2004 (2 pages).

\begin{tabular}{|c|c|c|c|c|c|c|c|c|c|c|c|c|}
\hline \multirow{2}{*}{$\begin{array}{c}X \\
(\mathrm{~m})\end{array}$} & \multicolumn{6}{|c|}{ 28-Mar-95 } & \multicolumn{6}{|c|}{ 30-Apr-03 } \\
\hline & BA1 & BA2 & BA3 & BA4 & BA5 & BA6 & BA1 & BA2 & BA3 & BA4 & BA5 & BA6 \\
\hline 32 & 0.1036 & 0.0963 & 0.0961 & 0.1030 & 0.0944 & 0.1024 & 0.0994837 & 0.0906815 & 0.0994265 & 0.0995408 & 0.0930059 & 0.0973879 \\
\hline 31 & 0.1011 & 0.0961 & 0.1006 & 0.1015 & 0.1002 & 0.1060 & 0.0987025 & 0.0910435 & 0.1030846 & 0.096702 & 0.0920342 & 0.0983405 \\
\hline 30 & 0.1026 & 0.0959 & 0.0996 & 0.0977 & 0.0942 & 0.1037 & 0.0994837 & 0.0936727 & 0.1025892 & 0.0949302 & 0.0928344 & 0.0962638 \\
\hline 29 & 0.1043 & 0.0951 & 0.0996 & 0.1019 & 0.0959 & 0.0937 & 0.0982453 & 0.0922438 & 0.1088194 & 0.0988931 & 0.0948349 & 0.0995218 \\
\hline 28 & 0.1028 & 0.0974 & 0.1016 & 0.1037 & 0.0988 & 0.1027 & 0.1015223 & 0.0949111 & 0.1063616 & 0.0982834 & 0.0949873 & 0.0997123 \\
\hline 27 & 0.1022 & 0.0965 & 0.1019 & 0.1049 & 0.0987 & 0.0954 & 0.0986073 & 0.0903957 & 0.1019224 & 0.0969688 & 0.091615 & 0.099598 \\
\hline 26 & 0.1041 & 0.0945 & 0.0977 & 0.1061 & 0.0995 & 0.0935 & 0.0983787 & 0.1006268 & 0.1045326 & 0.1083621 & 0.0938061 & 0.0903195 \\
\hline 25 & 0.1043 & 0.0963 & 0.0980 & 0.1078 & 0.0947 & 0.0984 & 0.0984358 & 0.1004744 & 0.1044564 & 0.1102483 & 0.0956161 & 0.1022653 \\
\hline 24 & 0.1053 & 0.0949 & 0.0999 & 0.1045 & 0.0973 & 0.1014 & 0.1030465 & 0.1021701 & 0.1076381 & 0.1104007 & 0.0957685 & 0.0984168 \\
\hline 23 & 0.1021 & 0.0995 & 0.1002 & 0.1029 & 0.0958 & 0.0968 & 0.1008936 & 0.0951016 & 0.1088956 & 0.103218 & 0.0968926 & 0.0928916 \\
\hline 22 & 0.1014 & 0.0968 & 0.1051 & 0.1050 & 0.0979 & 0.0967 & 0.102513 & 0.0929678 & 0.1121916 & 0.1022272 & 0.0931964 & 0.0942443 \\
\hline 21 & 0.1020 & 0.0950 & 0.1076 & 0.1087 & 0.0959 & 0.0938 & 0.1047231 & 0.0900146 & 0.1075429 & 0.1113533 & 0.0985882 & 0.0945682 \\
\hline 20 & 0.0987 & 0.0937 & 0.1118 & 0.1071 & 0.0935 & 0.0909 & 0.0932726 & 0.0957875 & 0.1145922 & 0.102513 & 0.0966449 & 0.0934441 \\
\hline 19 & 0.0986 & 0.0960 & 0.1082 & 0.1045 & 0.0944 & 0.0927 & 0.0960543 & 0.0924534 & 0.1120583 & 0.1007983 & 0.0986835 & 0.092701 \\
\hline 18 & 0.0997 & 0.0921 & 0.1129 & 0.1023 & 0.0983 & 0.0890 & 0.0931011 & 0.0958447 & 0.1062282 & 0.1008745 & 0.0957304 & 0.0908148 \\
\hline 17 & 0.1012 & 0.0942 & 0.1092 & 0.1024 & 0.0927 & 0.0932 & 0.1053518 & 0.0965496 & 0.1051423 & 0.1024178 & 0.0896908 & 0.0864137 \\
\hline 16 & 0.1024 & 0.0968 & 0.1145 & 0.1014 & 0.0942 & 0.0931 & 0.1051994 & 0.0963972 & 0.1044183 & 0.0991407 & 0.0899575 & 0.0877093 \\
\hline 15 & 0.1030 & 0.0967 & 0.1134 & 0.1015 & 0.0913 & 0.0912 & 0.1014461 & 0.097407 & 0.1016557 & 0.1008174 & 0.0899194 & 0.0884523 \\
\hline 14 & 0.0975 & 0.0947 & 0.1066 & 0.1028 & 0.0955 & 0.0932 & 0.0918246 & 0.087614 & 0.1031036 & 0.0995408 & 0.0956732 & 0.0903004 \\
\hline 13 & 0.0996 & 0.0973 & 0.1086 & 0.1026 & 0.0943 & 0.0922 & 0.097045 & 0.0906053 & 0.1006649 & 0.0982262 & 0.0979214 & 0.090872 \\
\hline 12 & 0.0959 & 0.0947 & 0.1056 & 0.1025 & 0.0906 & 0.0897 & 0.0931964 & 0.0896336 & 0.1014651 & 0.0987406 & 0.0917865 & 0.0905291 \\
\hline 11 & 0.0988 & 0.0935 & 0.1023 & 0.1027 & 0.0913 & 0.0937 & 0.1003029 & 0.0975213 & 0.1091814 & 0.0979214 & 0.0913674 & 0.0940919 \\
\hline 10 & 0.0996 & 0.0982 & 0.1075 & 0.1036 & 0.0910 & 0.0928 & 0.0999219 & 0.0961495 & 0.1067236 & 0.0983596 & 0.091615 & 0.0918437 \\
\hline 9 & 0.1005 & 0.0953 & 0.1082 & 0.1030 & 0.0868 & 0.0943 & 0.0974832 & 0.0942062 & 0.1044373 & 0.1102674 & 0.0874426 & 0.0938061 \\
\hline
\end{tabular}


Table A.2. Neutron Probe-Measured Water Contents $\left(\mathrm{m}^{3} \mathrm{~m}^{-3}\right)$ for Horizontal Neutron Tubes BA1 Through BA6 Under the Asphalt Layer of the Prototype Hanford Barrier; Measurements on March 28, 1995, and April 04, 2004 (2 pages).

\begin{tabular}{|c|c|c|c|c|c|c|c|c|c|c|c|c|}
\hline \multirow{2}{*}{$\begin{array}{c}X \\
(\mathrm{~m})\end{array}$} & \multicolumn{6}{|c|}{ 28-Mar-95 } & \multicolumn{6}{|c|}{ 30-Apr-03 } \\
\hline & BA1 & BA2 & BA3 & BA4 & BA5 & BA6 & BA1 & BA2 & BA3 & BA4 & BA5 & BA6 \\
\hline 8 & 0.1004 & 0.0961 & 0.1052 & 0.1039 & 0.0961 & 0.0890 & 0.1041325 & 0.0997314 & 0.105771 & 0.0994456 & 0.0850991 & 0.0913102 \\
\hline 7 & 0.1035 & 0.0955 & 0.1089 & 0.1006 & 0.0921 & 0.0874 & 0.1069332 & 0.0969688 & 0.0991407 & 0.1052185 & 0.0945491 & 0.1009317 \\
\hline 6 & 0.0994 & 0.0964 & 0.1050 & 0.1066 & 0.0930 & 0.0951 & 0.1055042 & 0.0993503 & 0.0990836 & 0.0995599 & 0.0918818 & 0.0935774 \\
\hline 5 & 0.1021 & 0.0983 & 0.1058 & 0.1021 & 0.0972 & 0.0960 & 0.1018652 & 0.100322 & 0.1003982 & 0.0995027 & 0.0937299 & 0.095216 \\
\hline 4 & 0.0992 & 0.0973 & 0.1060 & 0.1004 & 0.1109 & 0.0950 & 0.1066664 & 0.0982453 & 0.1001124 & 0.1026845 & 0.0901861 & 0.0918437 \\
\hline 3 & 0.1027 & 0.0978 & 0.1047 & 0.1026 & 0.1309 & 0.1062 & 0.1071618 & 0.1017509 & 0.1042277 & 0.1019033 & 0.0950445 & 0.095978 \\
\hline 2 & 0.1008 & 0.0996 & 0.1026 & 0.1057 & 0.1309 & 0.1172 & 0.1028 & 0.0998 & 0.1052 & 0.1060 & 0.1056 & 0.0954 \\
\hline 1 & 0.1065 & 0.1028 & 0.1170 & 0.1083 & 0.1315 & 0.1177 & 0.1066 & 0.1007 & 0.1258 & 0.1160 & 0.1186 & 0.0939 \\
\hline 0 & 0.1167 & 0.1112 & 0.1310 & 0.1297 & 0.1232 & 0.1271 & 0.1150 & 0.1109 & 0.1350 & 0.1348 & 0.1261 & 0.1107 \\
\hline-1 & 0.2196 & 0.1191 & 0.1439 & 0.1344 & 0.1148 & 0.1127 & 0.1463 & 0.1144 & 0.0852 & 0.1338 & 0.1265 & 0.1223 \\
\hline-2 & 0.1388 & 0.0751 & 0.1428 & 0.1313 & 0.1147 & 0.0977 & 0.1355 & 0.0797 & 0.1404 & 0.1331 & 0.1263 & 0.1206 \\
\hline-3 & 0.1282 & 0.0960 & 0.1518 & 0.1345 & 0.1224 & 0.1204 & 0.1272 & 0.0826 & 0.1493 & 0.1351 & 0.1200 & 0.1223 \\
\hline-4 & 0.1192 & 0.1137 & 0.1315 & 0.1314 & 0.1175 & 0.1224 & 0.1115 & 0.1082 & 0.1289 & 0.1341 & 0.1191 & 0.1225 \\
\hline-5 & 0.1151 & 0.1137 & 0.1247 & 0.1233 & 0.1197 & 0.1239 & 0.1037 & 0.1079 & 0.1235 & 0.1277 & 0.1167 & 0.1204 \\
\hline-6 & 0.1066 & 0.1130 & 0.1245 & 0.1284 & 0.1215 & 0.1256 & 0.0950 & 0.1019 & 0.1233 & 0.1248 & 0.1205 & 0.1181 \\
\hline-7 & 0.1000 & 0.1042 & 0.1270 & 0.1325 & 0.1134 & 0.1226 & 0.0820 & 0.0907 & 0.0558 & 0.1285 & 0.1145 & 0.1163 \\
\hline-8 & 0.0596 & 0.0620 & 0.1372 & 0.1207 & 0.1222 & 0.1326 & 0.0486 & 0.0743 & 0.1019 & 0.1125 & 0.1145 & 0.1170 \\
\hline-9 & & & 0.1393 & 0.1208 & 0.1139 & 0.1251 & & & 0.1335 & 0.1221 & 0.1162 & 0.1189 \\
\hline-10 & & & 0.1148 & 0.1135 & 0.1158 & 0.1282 & & & 0.1019 & 0.1031 & 0.1073 & 0.1155 \\
\hline-11 & & & 0.1084 & 0.1019 & 0.1020 & 0.1179 & & & 0.0875 & 0.0895 & 0.1094 & 0.1192 \\
\hline-12 & & & 0.0522 & 0.0429 & 0.0906 & 0.1027 & & & 0.0511 & 0.0582 & 0.1047 & 0.1169 \\
\hline-13 & & & & & 0.0532 & 0.0540 & & & & & 0.1100 & 0.1160 \\
\hline-14 & & -- & -- & -- & -- & -- & & & & & 0.0915 & 0.1075 \\
\hline-15 & -- & -- & -- & -- & -- & -- & -- & -- & -- & -- & -- & -- \\
\hline
\end{tabular}


Table A.3. Water Balance Summary for the Prototype Hanford Barrier, November 1994 Through August 2003. (3 pages)

\begin{tabular}{|c|c|c|c|c|c|c|c|c|c|c|c|c|c|}
\hline Plot & Date $\left(\mathrm{T}_{1}\right)$ & Date $\left(\mathrm{T}_{2}\right)$ & $\begin{array}{l}\Delta \mathrm{T}=\mathrm{T}_{2}-\mathrm{T}_{1} \\
\text { (days) }\end{array}$ & $\begin{array}{l}\text { Elapsed } \\
\text { Time } \\
\text { (days) }\end{array}$ & $\mathrm{P}(\mathrm{mm})$ & $\mathrm{I}(\mathrm{mm})$ & $\begin{array}{l}\mathrm{W}_{1} \\
(\mathrm{~mm})\end{array}$ & $\begin{array}{l}\mathrm{W}_{2} \\
(\mathrm{~mm})\end{array}$ & $\begin{array}{l}\Delta \mathrm{W} \\
(\mathrm{mm})\end{array}$ & $\begin{array}{l}\mathrm{R} \\
(\mathrm{mm})\end{array}$ & $\mathrm{D}(\mathrm{mm})$ & $\begin{array}{l}\text { Total ET } \\
(\mathrm{mm})\end{array}$ & $\begin{array}{l}\text { ET Rate } \\
\left(\mathrm{mm} \mathrm{d}^{-1}\right)\end{array}$ \\
\hline & 30-Sep-94 & 30-Sep-95 & 365 & 361 & 275.34 & 350.6 & 243.53 & 123.9 & -119.63 & 1.78 & $3.68 \mathrm{E}-05$ & 743.79 & 2.04 \\
\hline & 30-Sep-95 & 30-Sep-96 & 366 & 727 & 241.81 & 247.35 & 123.9 & 135.47 & 11.57 & 0 & $1.74 \mathrm{E}-02$ & 477.57 & 1.30 \\
\hline & 30-Sep-96 & 30-Sep-97 & 365 & 1092 & 290.58 & 224.92 & 135.47 & 149.3 & 13.83 & 36.3 & $1.84 \mathrm{E}-04$ & 465.37 & 1.27 \\
\hline & 30-Sep-97 & 30-Sep-98 & 365 & 1457 & 169.67 & 200 & 149.3 & 149.25 & -0.05 & 0 & $1.76 \mathrm{E}-02$ & 369.70 & 1.01 \\
\hline \multirow[t]{6}{*}{$6 \mathrm{~W}$} & 30-Sep-98 & 30-Sep-99 & 365 & 1822 & 125.73 & 0 & 149.25 & 129.05 & -20.2 & 0 & $3.71 \mathrm{E}-04$ & 145.93 & 0.40 \\
\hline & 30-Sep-99 & $30-$ Sep- 00 & 366 & 2188 & 170.43 & 0 & 129.05 & 121.02 & -8.02 & 0 & $0.00 \mathrm{E}+00$ & 178.45 & 0.49 \\
\hline & $30-$ Sep- 00 & 30-Sep-01 & 365 & 2553 & 154.94 & 0 & 121.02 & 116.75 & -4.27 & 0 & $0.00 \mathrm{E}+00$ & 159.21 & 0.44 \\
\hline & $30-$ Sep-01 & $30-$ Sep-02 & 365 & 2918 & 136.65 & 0 & 116.75 & 106.91 & -9.84 & 0 & $1.00 \mathrm{E}-09$ & 146.49 & 0.40 \\
\hline & 30-Sep-02 & 30-Sep-03 & 365 & 3283 & 224.03 & 0 & 106.91 & 100.7 & -6.21 & 0 & $3.68 \mathrm{E}-05$ & 230.24 & 0.63 \\
\hline & $30-$ Sep-03 & 30-Sep-04 & 366 & 3649 & 218.95 & 0 & 100.7 & 114.02 & 13.32329 & 0 & $0.00 \mathrm{E}+00$ & 205.63 & 0.56 \\
\hline & & & & & & & & & & & & & \\
\hline & 30-Sep-94 & 30-Sep-95 & 365 & 361 & 275.34 & 350.6 & 233.43 & 112.54 & -120.89 & 1.78 & $1.30 \mathrm{E}-08$ & 745.05 & 2.04 \\
\hline & 30-Sep-95 & 30-Sep-96 & 366 & 727 & 241.81 & 247.35 & 112.54 & 124.54 & 11.99 & 0 & $1.40 \mathrm{E}-03$ & 477.17 & 1.30 \\
\hline & 30-Sep-96 & 30-Sep-97 & 365 & 1092 & 290.58 & 224.92 & 124.54 & 165.07 & 40.53 & 36.3 & $1.81 \mathrm{E}-01$ & 438.49 & 1.20 \\
\hline & 30-Sep-97 & 30-Sep-98 & 365 & 1457 & 169.67 & 200 & 165.07 & 165.38 & 0.31 & 0 & $2.10 \mathrm{E}-02$ & 369.34 & 1.01 \\
\hline \multirow[t]{9}{*}{$6 \mathrm{E}$} & 30-Sep-98 & 30-Sep-99 & 365 & 1822 & 125.73 & 0 & 165.38 & 123.75 & -41.63 & 0 & 7.78E-03 & 167.35 & 0.46 \\
\hline & 30-Sep-99 & $30-$ Sep- 00 & 366 & 2188 & 170.43 & 0 & 123.75 & 117.9 & -5.85 & 0 & $0.00 \mathrm{E}+00$ & 176.28 & 0.48 \\
\hline & 30-Sep-00 & 30-Sep-01 & 365 & 2553 & 154.94 & 0 & 117.9 & 111.08 & -6.81 & 0 & $5.05 \mathrm{E}-03$ & 161.74 & 0.44 \\
\hline & 30-Sep-01 & 30-Sep-02 & 365 & 2918 & 136.65 & 0 & 111.08 & 106.3 & -4.78 & 0 & $0.00 \mathrm{E}+00$ & 141.43 & 0.39 \\
\hline & $30-$ Sep-02 & $30-$ Sep-03 & 365 & 3283 & 224.03 & 0 & 106.3 & 99.35 & -6.95 & 0 & $3.58 \mathrm{E}-05$ & 230.98 & 0.63 \\
\hline & 30-Sep-03 & 30-Sep-04 & 366 & 3649 & 218.95 & 0 & 99.35 & 112.5 & 13.14831 & 0 & $0.00 \mathrm{E}+00$ & 205.80 & 0.56 \\
\hline & 30-Sep-94 & 30-Sep-95 & 365 & 361 & 275.34 & 0 & 225.67 & 110.24 & -115.43 & 0 & $3.26 \mathrm{E}-05$ & 390.77 & 1.07 \\
\hline & 30-Sep-95 & 30-Sep-96 & 366 & 727 & 241.81 & 0 & 110.24 & 104.28 & -5.96 & 0 & $3.26 \mathrm{E}-05$ & 247.77 & 0.68 \\
\hline & 30-Sep-96 & 30-Sep-97 & 365 & 1092 & 290.58 & 0 & 104.28 & 112.69 & 8.41 & 0 & $2.28 \mathrm{E}-04$ & 282.17 & 0.77 \\
\hline
\end{tabular}


Table A.3. Water Balance Summary for the Prototype Hanford Barrier, November 1994 Through August 2003. (3 pages)

\begin{tabular}{|c|c|c|c|c|c|c|c|c|c|c|c|c|c|}
\hline Plot & Date $\left(\mathrm{T}_{1}\right)$ & Date $\left(\mathrm{T}_{2}\right)$ & $\begin{array}{l}\Delta \mathrm{T}=\mathrm{T}_{2}-\mathrm{T}_{1} \\
\text { (days) }\end{array}$ & $\begin{array}{l}\text { Elapsed } \\
\text { Time } \\
\text { (days) }\end{array}$ & $\mathrm{P}(\mathrm{mm})$ & $\mathrm{I}(\mathrm{mm})$ & $\begin{array}{l}\mathrm{W}_{1} \\
(\mathrm{~mm})\end{array}$ & $\begin{array}{l}\mathrm{W}_{2} \\
(\mathrm{~mm})\end{array}$ & $\begin{array}{l}\Delta \mathrm{W} \\
(\mathrm{mm})\end{array}$ & $\begin{array}{l}\mathrm{R} \\
(\mathrm{mm})\end{array}$ & $\mathrm{D}(\mathrm{mm})$ & $\begin{array}{l}\text { Total ET } \\
(\mathrm{mm})\end{array}$ & $\begin{array}{l}\text { ET Rate } \\
\left(\mathrm{mm} \mathrm{d}^{-1}\right)\end{array}$ \\
\hline & 30-Sep-97 & 30-Sep-98 & 365 & 1457 & 169.67 & 0 & 112.69 & 112.7 & 0.01 & 0 & $0.00 \mathrm{E}+00$ & 169.66 & 0.46 \\
\hline \multirow[t]{10}{*}{$3 \mathrm{~W}$} & 30-Sep-98 & 30-Sep-99 & 365 & 1822 & 125.73 & 0 & 112.7 & 114 & 1.3 & 0 & $0.00 \mathrm{E}+00$ & 124.43 & 0.34 \\
\hline & 30-Sep-99 & $30-$ Sep- 00 & 366 & 2188 & 170.43 & 0 & 112.69 & 113.53 & 0.84 & 0 & $0.00 \mathrm{E}+00$ & 169.59 & 0.46 \\
\hline & $30-$ Sep-00 & 30-Sep-01 & 365 & 2553 & 154.94 & 0 & 113.53 & 106.96 & -6.57 & 0 & $0.00 \mathrm{E}+00$ & 161.51 & 0.44 \\
\hline & 30-Sep-01 & $30-$ Sep-02 & 365 & 2918 & 136.65 & 0 & 106.96 & 101.76 & -5.19 & 0 & $0.00 \mathrm{E}+00$ & 141.84 & 0.39 \\
\hline & $30-$ Sep-02 & $30-$ Sep-03 & 365 & 3283 & 224.03 & 0 & 101.76 & 96.03 & -5.73 & 0 & $0.00 \mathrm{E}+00$ & 229.76 & 0.63 \\
\hline & $30-$ Sep-03 & 30-Sep-04 & 366 & 3649 & 218.95 & 0 & 96.03 & 111.32 & 15.29457 & 0 & $0.00 \mathrm{E}+00$ & 203.66 & 0.56 \\
\hline & 30-Sep-94 & $30-$ Sep-95 & 365 & 361 & 275.34 & 0 & 229.6 & 103.87 & -125.73 & 0 & $2.01 \mathrm{E}-02$ & 401.05 & 1.10 \\
\hline & 30-Sep-95 & $30-$ Sep-96 & 366 & 727 & 241.81 & 0 & 103.87 & 99.84 & -4.03 & 0 & $6.75 \mathrm{E}-02$ & 245.77 & 0.67 \\
\hline & 30-Sep-96 & $30-$ Sep-97 & 365 & 1092 & 290.58 & 0 & 99.75 & 108.41 & 8.66 & 0 & $1.80 \mathrm{E}-04$ & 281.92 & 0.77 \\
\hline & 30-Sep-97 & $30-$ Sep-98 & 365 & 1457 & 169.67 & 0 & 112.69 & 112.7 & 0.01 & 0 & $0.00 \mathrm{E}+00$ & 169.66 & 0.46 \\
\hline \multirow[t]{10}{*}{$3 \mathrm{~W}$} & 30-Sep-98 & 30-Sep-99 & 365 & 1822 & 125.73 & 0 & 112.7 & 114 & 1.3 & 0 & $0.00 \mathrm{E}+00$ & 124.43 & 0.34 \\
\hline & 30-Sep-99 & $30-$ Sep-00 & 366 & 2188 & 170.43 & 0 & 112.69 & 113.53 & 0.84 & 0 & $0.00 \mathrm{E}+00$ & 169.59 & 0.46 \\
\hline & $30-$ Sep-00 & $30-$ Sep-01 & 365 & 2553 & 154.94 & 0 & 113.53 & 106.96 & -6.57 & 0 & $0.00 \mathrm{E}+00$ & 161.51 & 0.44 \\
\hline & $30-$ Sep-01 & $30-$ Sep-02 & 365 & 2918 & 136.65 & 0 & 106.96 & 101.76 & -5.19 & 0 & $0.00 \mathrm{E}+00$ & 141.84 & 0.39 \\
\hline & $30-$ Sep-02 & $30-$ Sep-03 & 365 & 3283 & 224.03 & 0 & 101.76 & 96.03 & -5.73 & 0 & $0.00 \mathrm{E}+00$ & 229.76 & 0.63 \\
\hline & 30-Sep-03 & 30-Sep-04 & 366 & 3649 & 218.95 & 0 & 96.03 & 111.32 & 15.29457 & 0 & $0.00 \mathrm{E}+00$ & 203.66 & 0.56 \\
\hline & 30-Sep-94 & $30-$ Sep-95 & 365 & 361 & 275.34 & 0 & 229.6 & 103.87 & -125.73 & 0 & $2.01 \mathrm{E}-02$ & 401.05 & 1.10 \\
\hline & 30-Sep-95 & 30-Sep-96 & 366 & 727 & 241.81 & 0 & 103.87 & 99.84 & -4.03 & 0 & $6.75 \mathrm{E}-02$ & 245.77 & 0.67 \\
\hline & 30-Sep-96 & $30-$ Sep-97 & 365 & 1092 & 290.58 & 0 & 99.75 & 108.41 & 8.66 & 0 & $1.80 \mathrm{E}-04$ & 281.92 & 0.77 \\
\hline & 30-Sep-97 & $30-$ Sep-98 & 365 & 1457 & 169.67 & 0 & 108.41 & 108.28 & -0.12 & 0 & $0.00 \mathrm{E}+00$ & 169.79 & 0.47 \\
\hline \multirow[t]{2}{*}{$3 \mathrm{E}$} & 30-Sep-98 & 30-Sep-99 & 365 & 1822 & 125.73 & 0 & 108.28 & 109.77 & 1.49 & 0 & $0.00 \mathrm{E}+00$ & 124.24 & 0.34 \\
\hline & 30-Sep-99 & $30-$ Sep-00 & 366 & 2188 & 170.43 & 0 & 109.77 & 111.26 & 1.49 & 0 & $0.00 \mathrm{E}+00$ & 168.94 & 0.46 \\
\hline
\end{tabular}


Table A.3. Water Balance Summary for the Prototype Hanford Barrier, November 1994 Through August 2003. (3 pages)

\begin{tabular}{|c|c|c|c|c|c|c|c|c|c|c|c|c|c|}
\hline Plot & Date $\left(\mathrm{T}_{1}\right)$ & Date $\left(\mathrm{T}_{2}\right)$ & $\begin{array}{l}\Delta \mathrm{T}=\mathrm{T}_{2}-\mathrm{T}_{1} \\
\text { (days) }\end{array}$ & $\begin{array}{l}\text { Elapsed } \\
\text { Time } \\
\text { (days) }\end{array}$ & $\mathrm{P}(\mathrm{mm})$ & $\mathrm{I}(\mathrm{mm})$ & $\begin{array}{l}\mathrm{W}_{1} \\
(\mathrm{~mm})\end{array}$ & $\begin{array}{l}\mathrm{W}_{2} \\
(\mathrm{~mm})\end{array}$ & $\begin{array}{l}\Delta \mathrm{W} \\
(\mathrm{mm})\end{array}$ & $\begin{array}{l}\mathrm{R} \\
(\mathrm{mm})\end{array}$ & $\mathrm{D}(\mathrm{mm})$ & $\begin{array}{l}\text { Total ET } \\
(\mathrm{mm})\end{array}$ & $\begin{array}{l}\text { ET Rate } \\
\left(\mathrm{mm} \mathrm{d}^{-1}\right)\end{array}$ \\
\hline & $30-$ Sep-00 & $30-$ Sep-01 & 365 & 2553 & 154.94 & 0 & 111.26 & 114.61 & 3.35 & 0 & $0.00 \mathrm{E}+00$ & 151.59 & 0.42 \\
\hline & 30-Sep-01 & $30-$ Sep-02 & 365 & 2918 & 136.65 & 0 & 114.61 & 100.18 & -14.44 & 0 & $0.00 \mathrm{E}+00$ & 151.09 & 0.41 \\
\hline & $30-$ Sep- 02 & $30-$ Sep-03 & 365 & 3283 & 224.03 & 0 & 100.18 & 93.9 & -6.28 & 0 & $3.60 \mathrm{E}-05$ & 230.31 & 0.63 \\
\hline & 30-Sep-03 & 30-Sep-04 & 366 & 3649 & 218.95 & 0 & 93.9 & 108.99 & 15.08834 & 0 & $0.00 \mathrm{E}+00$ & 203.86 & 0.56 \\
\hline
\end{tabular}

$\stackrel{P}{D}$ 
Table A.4. Prototype Hanford Barrier Surface Elevations (in Meters Above Mean Sea Level) on May 14, 2004. Locations represent distance in meters from Stake 1,1 (Figure 1). (Two pages)

\begin{tabular}{|c|c|c|c|c|c|c|c|c|c|c|c|c|c|c|c|c|c|c|c|c|c|c|c|c|c|c|}
\hline \multicolumn{3}{|c|}{ Location } & \multicolumn{3}{|c|}{ Location } & \multicolumn{3}{|c|}{ Location } & \multicolumn{3}{|c|}{ Location } & \multicolumn{3}{|c|}{ Location } & \multicolumn{3}{|c|}{ Location } & \multicolumn{3}{|c|}{ Location } & \multicolumn{3}{|c|}{ Location } & \multicolumn{3}{|c|}{ Location } \\
\hline E & $\mathbf{N}$ & Elevation & $\mathbf{E}$ & $\mathbf{N}$ & Elevation & $\mathbf{E}$ & $\mathbf{N}$ & Elevation & $\mathbf{E}$ & $\mathbf{N}$ & Elevation & $\mathbf{E}$ & $\mathbf{N}$ & Elevation & $\mathbf{E}$ & $\mathbf{N}$ & Elevation & $\mathbf{E}$ & $\mathbf{N}$ & Elevation & E & $\mathbf{N}$ & Elevation & E & $\mathbf{N}$ & Elevation \\
\hline 0 & 0 & 201.666 & 0 & 9 & \begin{tabular}{|l|l|}
201.804 \\
\end{tabular} & 0 & 18 & 201.871 & 0 & 27 & \begin{tabular}{|l|l|}
201.870 \\
\end{tabular} & 0 & 36 & 201.811 & 0 & 45 & \begin{tabular}{|l|l|}
201.797 \\
\end{tabular} & 0 & 54 & 201.779 & 0 & 63 & \begin{tabular}{|l|l|}
201.790 \\
\end{tabular} & 0 & 72 & \begin{tabular}{|l|l|}
201.803 \\
\end{tabular} \\
\hline 3 & 0 & 201.750 & 3 & 9 & 201.859 & 3 & 18 & 201.866 & 3 & 27 & \begin{tabular}{|l|l}
201.929 \\
\end{tabular} & 3 & 36 & 201.884 & 3 & 45 & 201.866 & 3 & \begin{tabular}{|l|l|}
54 \\
\end{tabular} & 201.844 & 3 & 63 & 201.798 & 3 & 72 & 201.857 \\
\hline 6 & 0 & 201.872 & 6 & 9 & 201.930 & 6 & 18 & 201.908 & 6 & 27 & \begin{tabular}{|l|l}
202.005 \\
\end{tabular} & 6 & 36 & 201.953 & 6 & 45 & \begin{tabular}{|l|l}
201.926 \\
\end{tabular} & 6 & \begin{tabular}{|l|l|}
54 \\
\end{tabular} & 201.926 & 6 & 63 & 201.882 & 6 & 72 & 201.958 \\
\hline 9 & 0 & 201.922 & 9 & 9 & 201.981 & 9 & 18 & 201.985 & 9 & 27 & \begin{tabular}{|l|l}
202.082 \\
\end{tabular} & 9 & 36 & 201.980 & 9 & 45 & \begin{tabular}{|l|l}
201.997 \\
\end{tabular} & 9 & \begin{tabular}{|l|l}
54 \\
\end{tabular} & 201.989 & 9 & 63 & 201.978 & 9 & 72 & 201.981 \\
\hline 12 & 0 & 202.004 & 12 & 9 & 202.080 & 12 & 18 & 202.050 & 12 & 27 & 202.054 & 12 & 36 & 201.984 & 12 & 45 & \begin{tabular}{|l|}
202.017 \\
\end{tabular} & 12 & 54 & 202.012 & 12 & 63 & 202.098 & 12 & 72 & 202.056 \\
\hline 15 & 0 & 202.049 & 15 & 9 & 202.118 & 15 & 18 & 202.046 & 15 & \begin{tabular}{|l|l|}
27 \\
\end{tabular} & \begin{tabular}{|l|l}
202.091 \\
\end{tabular} & 15 & 36 & 202.054 & 15 & 45 & \begin{tabular}{|l}
202.087 \\
\end{tabular} & 15 & 54 & 202.124 & 15 & 63 & 202.107 & 15 & 72 & 202.018 \\
\hline 18 & 0 & 202.035 & 18 & 9 & 202.151 & 18 & 18 & 202.098 & 18 & 27 & \begin{tabular}{|l|l|}
202.067 \\
\end{tabular} & 18 & 36 & 202.112 & 18 & 45 & \begin{tabular}{|l|l}
202.133 \\
\end{tabular} & 18 & 54 & 202.090 & 18 & 63 & 202.115 & 18 & 72 & 201.974 \\
\hline 21 & 0 & 202.006 & 21 & 9 & \begin{tabular}{|l|l|}
202.098 \\
\end{tabular} & 21 & 18 & 202.080 & 21 & 27 & 202.046 & 21 & 36 & 202.103 & 21 & 45 & \begin{tabular}{|l|l|}
202.112 \\
\end{tabular} & 21 & 54 & 202.078 & 21 & 63 & 202.117 & 21 & 72 & \begin{tabular}{|l|l|}
201.998 \\
\end{tabular} \\
\hline 24 & 0 & 201.948 & 24 & 9 & 202.093 & 24 & 18 & 202.020 & 24 & 27 & 202.027 & 24 & 36 & 202.068 & 24 & 45 & 202.016 & 24 & 54 & 202.027 & 24 & 63 & 202.049 & 24 & 72 & 201.965 \\
\hline 27 & 0 & 201.926 & 27 & 9 & 202.028 & 27 & 18 & 201.967 & 27 & 27 & 201.913 & 27 & 36 & 201.976 & 27 & 45 & 201.965 & 27 & 54 & 201.957 & 27 & 63 & \begin{tabular}{|l|}
201.971 \\
\end{tabular} & 27 & 72 & 201.889 \\
\hline 30 & 0 & 201.845 & 30 & 9 & 201.951 & 30 & 18 & 201.899 & 30 & 27 & \begin{tabular}{|l|l|}
201.890 \\
\end{tabular} & 30 & 36 & 201.888 & 30 & 45 & 201.906 & 30 & 54 & 201.812 & 30 & 63 & 201.843 & 30 & 72 & 201.766 \\
\hline 33 & 0 & 201.744 & 33 & 9 & 201.760 & 33 & 18 & 201.781 & 33 & 27 & 201.786 & 33 & 36 & 201.800 & 33 & 45 & 201.818 & 33 & 54 & 201.772 & 33 & 63 & 201.767 & 33 & 72 & 201.630 \\
\hline 36 & 0 & 201.601 & 36 & 9 & 201.628 & 36 & 18 & \begin{tabular}{|l|}
201.684 \\
\end{tabular} & 36 & 27 & \begin{tabular}{|l|l|}
201.714 \\
\end{tabular} & 36 & 36 & 201.692 & 36 & 45 & \begin{tabular}{|l}
201.719 \\
\end{tabular} & 36 & 54 & 201.681 & 36 & 63 & \begin{tabular}{|l}
201.647 \\
\end{tabular} & 36 & 72 & 201.609 \\
\hline 0 & 3 & 201.725 & 0 & 12 & 201.906 & 0 & 21 & 201.866 & 0 & 30 & \begin{tabular}{|l|l}
201.887 \\
\end{tabular} & 0 & 39 & 201.822 & 0 & \begin{tabular}{|l|l}
48 \\
\end{tabular} & 201.805 & 0 & \begin{tabular}{|l|}
57 \\
\end{tabular} & 201.810 & 0 & 66 & \begin{tabular}{|l|l}
201.790 \\
\end{tabular} & 0 & 75 & 201.750 \\
\hline 3 & 3 & 201.755 & 3 & 12 & 201.894 & 3 & 21 & 201.877 & 3 & 30 & 201.923 & 3 & 39 & 201.865 & 3 & 48 & \begin{tabular}{|l|}
201.859 \\
\end{tabular} & 3 & 57 & 201.817 & 3 & 66 & 201.841 & 3 & 75 & 201.747 \\
\hline 6 & 3 & 201.865 & 6 & 12 & 201.962 & 6 & 21 & 201.932 & 6 & 30 & 201.940 & 6 & 39 & 201.947 & 6 & 48 & \begin{tabular}{|l|}
201.917 \\
\end{tabular} & 6 & 57 & 201.893 & 6 & 66 & \begin{tabular}{|l|l|}
201.877 \\
\end{tabular} & 6 & 75 & 201.855 \\
\hline 9 & 3 & 201.983 & 9 & 12 & 202.025 & 9 & 21 & 202.041 & 9 & 30 & 202.033 & 9 & 39 & 201.990 & 9 & 48 & \begin{tabular}{|l|l|}
201.960 \\
\end{tabular} & 9 & 57 & 201.909 & 9 & 66 & \begin{tabular}{|l|l}
202.018 \\
\end{tabular} & 9 & 75 & 201.890 \\
\hline 12 & 3 & 202.025 & 12 & 12 & 202.069 & 12 & 21 & 202.074 & 12 & 30 & \begin{tabular}{|l|}
202.055 \\
\end{tabular} & 12 & 39 & 201.977 & 12 & \begin{tabular}{|l|l}
48 \\
\end{tabular} & \begin{tabular}{|l|l|}
201.986 \\
\end{tabular} & 12 & 57 & 202.027 & 12 & 66 & \begin{tabular}{|l|}
202.045 \\
\end{tabular} & 12 & 75 & 201.979 \\
\hline 15 & 3 & 202.060 & 15 & 12 & 202.114 & 15 & 21 & 202.064 & 15 & 30 & 202.085 & 15 & 39 & 202.031 & 15 & 48 & 202.106 & 15 & 57 & 202.109 & 15 & 66 & 202.103 & 15 & 75 & 201.985 \\
\hline 18 & 3 & 202.074 & 18 & 12 & \begin{tabular}{|l|l|}
202.153 \\
\end{tabular} & 18 & 21 & 202.080 & 18 & 30 & \begin{tabular}{|l|l|}
202.079 \\
\end{tabular} & 18 & 39 & 202.096 & 18 & 48 & 202.070 & 18 & 57 & 202.098 & 18 & 66 & 202.087 & 18 & 75 & 201.925 \\
\hline 21 & 3 & 202.030 & 21 & 12 & 202.122 & 21 & 21 & \begin{tabular}{|l|l|}
202.046 \\
\end{tabular} & 21 & 30 & \begin{tabular}{|l|l}
202.077 \\
\end{tabular} & 21 & 39 & 202.093 & 21 & $\begin{array}{lll}48 \\
\end{array}$ & 202.068 & 21 & \begin{tabular}{|l|l|}
57 \\
\end{tabular} & 202.090 & 21 & 66 & 202.135 & 21 & 75 & 201.888 \\
\hline 24 & 3 & 201.956 & 24 & 12 & \begin{tabular}{|l|l|}
202.079 \\
\end{tabular} & 24 & 21 & 202.004 & 24 & 30 & 202.033 & 24 & 39 & 202.001 & 24 & \begin{tabular}{|l|l}
48 \\
\end{tabular} & 201.995 & 24 & 57 & 202.011 & 24 & 66 & 202.003 & 24 & 75 & 201.815 \\
\hline 27 & 3 & 201.949 & 27 & 12 & 202.049 & 27 & 21 & 201.990 & 27 & 30 & 201.922 & 27 & 39 & 201.926 & 27 & \begin{tabular}{|l|l|}
48 \\
\end{tabular} & 201.934 & 27 & \begin{tabular}{|l|}
57 \\
\end{tabular} & 201.911 & 27 & 66 & 201.907 & 27 & 75 & 201.812 \\
\hline 30 & 3 & 201.858 & 30 & 12 & 201.966 & 30 & 21 & 201.897 & 30 & 30 & 201.845 & 30 & 39 & 201.884 & 30 & 48 & 201.908 & 30 & \begin{tabular}{|l|}
57 \\
\end{tabular} & 201.783 & 30 & $\begin{array}{ll}66 \\
\end{array}$ & 201.821 & 30 & 75 & 201.756 \\
\hline 33 & 3 & 201.697 & 33 & 12 & \begin{tabular}{|l}
201.797 \\
\end{tabular} & 33 & 21 & 201.776 & 33 & 30 & \begin{tabular}{|l|l}
201.749 \\
\end{tabular} & 33 & 39 & 201.790 & 33 & 48 & \begin{tabular}{|l}
201.794 \\
\end{tabular} & 33 & 57 & 201.774 & 33 & \begin{tabular}{|l|l|}
66 \\
\end{tabular} & 201.703 & 33 & 75 & 201.612 \\
\hline 36 & 3 & 201.610 & 36 & 12 & \begin{tabular}{|l}
201.657 \\
\end{tabular} & 36 & 21 & 201.624 & 36 & 30 & \begin{tabular}{|l|l|}
201.669 \\
\end{tabular} & 36 & 39 & 201.712 & 36 & 48 & 201.690 & 36 & 57 & 201.649 & 36 & 66 & 201.610 & 36 & 75 & 201.636 \\
\hline 0 & 6 & 201.722 & 0 & 15 & \begin{tabular}{|l|}
201.839 \\
\end{tabular} & 0 & 24 & 201.873 & 0 & 33 & \begin{tabular}{|l|}
201.884 \\
\end{tabular} & 0 & 42 & 201.798 & 0 & 51 & \begin{tabular}{|l|l|}
201.830 \\
\end{tabular} & 0 & 60 & 201.808 & 0 & \begin{tabular}{|l|l|}
69 \\
\end{tabular} & \begin{tabular}{|l|l|}
201.818 \\
\end{tabular} & -- & -- & --- \\
\hline 3 & 6 & 201.801 & 3 & 15 & 201.881 & 3 & 24 & 201.892 & 3 & 33 & \begin{tabular}{|l|}
201.871 \\
\end{tabular} & 3 & 42 & 201.880 & 3 & 51 & \begin{tabular}{|l|l|}
201.874 \\
\end{tabular} & 3 & 60 & 201.858 & 3 & $\begin{array}{ll}69 \\
\end{array}$ & 201.871 & -- & -- & - \\
\hline 6 & 6 & 201.861 & 6 & 15 & 201.919 & 6 & 24 & 201.976 & 6 & 33 & 201.930 & 6 & 42 & 201.959 & 6 & 51 & 201.902 & 6 & 60 & 201.890 & 6 & 69 & 201.941 & - & -- & - \\
\hline 9 & 6 & 201.914 & 9 & 15 & 201.946 & 9 & 24 & 202.028 & 9 & 33 & \begin{tabular}{|l}
202.009 \\
\end{tabular} & 9 & 42 & 201.968 & 9 & 51 & \begin{tabular}{|l}
201.963 \\
\end{tabular} & 9 & 60 & 201.993 & 9 & 69 & \begin{tabular}{|l}
202.025 \\
\end{tabular} & -- & -- & -- \\
\hline 12 & 6 & 202.011 & 12 & 15 & 202.036 & 12 & 24 & 202.057 & 12 & 33 & 202.069 & 12 & 42 & 201.965 & 12 & 51 & 202.013 & 12 & 60 & 202.055 & 12 & 69 & \begin{tabular}{|l}
202.099 \\
\end{tabular} & -- & -- & -- \\
\hline 15 & 6 & 202.066 & 15 & 15 & \begin{tabular}{|l}
202.067 \\
\end{tabular} & 15 & 24 & 202.036 & 15 & 33 & \begin{tabular}{|l}
202.059 \\
\end{tabular} & 15 & 42 & 202.083 & 15 & 51 & \begin{tabular}{|l|l|}
202.104
\end{tabular} & 15 & 60 & 202.139 & 15 & 69 & 202.116 & -- & -- & -- \\
\hline 18 & 6 & 202.120 & 18 & 15 & 202.093 & 18 & 24 & 202.049 & 18 & 33 & 202.095 & 18 & 42 & 202.140 & 18 & 51 & 202.148 & 18 & $\begin{array}{ll}60 \\
\end{array}$ & 202.131 & 18 & $\begin{array}{ll}69 \\
\end{array}$ & 202.135 & -- & -- & -- \\
\hline 21 & 6 & 202.101 & 21 & 15 & 202.103 & 21 & 24 & 202.028 & 21 & 33 & \begin{tabular}{|l}
202.042 \\
\end{tabular} & 21 & 42 & 202.097 & 21 & 51 & 202.080 & 21 & \begin{tabular}{|l|l}
60 \\
\end{tabular} & 202.100 & 21 & $\begin{array}{ll}69 \\
\end{array}$ & 202.056 & -- & - & - \\
\hline 24 & 6 & 202.049 & 24 & 15 & 202.009 & 24 & 24 & 202.050 & 24 & 33 & \begin{tabular}{|l|l|}
202.050 \\
\end{tabular} & 24 & 42 & 202.026 & 24 & 51 & \begin{tabular}{|l|}
201.993 \\
\end{tabular} & 24 & 60 & 202.054 & 24 & \begin{tabular}{|l|l|}
69 \\
\end{tabular} & 202.002 & -- & -- & -- \\
\hline 27 & 6 & 202.015 & 27 & 15 & 202.026 & 27 & 24 & 201.972 & 27 & 33 & \begin{tabular}{|l|}
201.991 \\
\end{tabular} & 27 & 42 & 201.922 & 27 & 51 & \begin{tabular}{|l|l|}
201.900 \\
\end{tabular} & 27 & 60 & 201.972 & 27 & \begin{tabular}{|l|l|l|}
69 \\
\end{tabular} & \begin{tabular}{|l|l|}
201.932 \\
\end{tabular} & -- & -- & \begin{tabular}{|l|l}
-- \\
\end{tabular} \\
\hline 30 & 6 & 201.881 & 30 & 15 & 201.929 & 30 & 24 & 201.878 & 30 & 33 & 201.866 & 30 & 42 & 201.866 & 30 & 51 & \begin{tabular}{|l|l}
201.866 \\
\end{tabular} & 30 & 60 & 201.822 & 30 & \begin{tabular}{|l|l|}
69 \\
\end{tabular} & \begin{tabular}{|l|l}
201.778 \\
\end{tabular} & -- & -- & -- \\
\hline
\end{tabular}


Table A.4. Prototype Hanford Barrier Surface Elevations (in Meters Above Mean Sea Level) on May 14, 2004. Locations represent distance in meters from Stake 1,1 (Figure 1). (Two pages)

\begin{tabular}{|c|c|c|c|c|c|c|c|c|c|c|c|c|c|c|c|c|c|c|c|c|c|c|c|c|c|c|}
\hline \multicolumn{3}{|c|}{ Location } & \multicolumn{3}{|c|}{ Location } & \multicolumn{3}{|c|}{ Location } & \multicolumn{3}{|c|}{ Location } & \multicolumn{3}{|c|}{ Location } & \multicolumn{3}{|c|}{ Location } & \multicolumn{3}{|c|}{ Location } & \multicolumn{3}{|c|}{ Location } & \multicolumn{3}{|c|}{ Location } \\
\hline 33 & 6 & 201.743 & 33 & 15 & 201.787 & 33 & 24 & 201.738 & 33 & 33 & 201.750 & 33 & 42 & 201.815 & 33 & 51 & 201.750 & 33 & 60 & 201.751 & 33 & 69 & 201.725 & -- & -- & -- \\
\hline 36 & 6 & 201.628 & 36 & 15 & 201.661 & 36 & 24 & 201.613 & 36 & 33 & 201.691 & 36 & 42 & 201.770 & 36 & 51 & 201.685 & 36 & 60 & 201.636 & 36 & 69 & 201.559 & -- & -- & -- \\
\hline
\end{tabular}

Table A.5. Elevations and Elevation Changes, in Meters,

of Settlement Gauges from December 1994.

\begin{tabular}{|l|l|l|l|l||}
\hline \multicolumn{5}{|c|}{ of Settlement Gauges from December 1994. } \\
\hline Date & DSG1 $(\mathrm{W})$ & $\begin{array}{l}\text { Elevation Change } \\
(\mathrm{m})\end{array}$ & DSG2 (E) & $\begin{array}{l}\text { levation Change } \\
(\mathrm{m})\end{array}$ \\
\hline Dec-94 & 201.954 & 0 & 201.687 & 0 \\
\hline Sep-95 & 201.958 & 0.004 & 201.69 & 0.003 \\
\hline Jan-96 & 201.967 & 0.013 & 201.698 & 0.011 \\
\hline Sep-96 & 201.965 & 0.011 & 201.698 & 0.011 \\
\hline Jan-97 & 201.961 & 0.007 & 201.686 & -0.001 \\
\hline Sep-97 & 201.963 & 0.009 & 201.698 & 0.011 \\
\hline Jul-99 & 201.95 & -0.004 & 201.683 & -0.004 \\
\hline Aug-00 & 201.951 & -0.003 & 201.658 & -0.029 \\
\hline Aug-01 & 201.947 & -0.007 & 201.675 & -0.012 \\
\hline Aug-02 & 201.948 & -0.006 & 201.683 & -0.004 \\
\hline Aug-03 & 201.953 & -0.001 & 201.687 & 0 \\
\hline May-04 & 202.032 & 0.078 & 201.763 & 0.076 \\
\hline
\end{tabular}


Table A.6. Prototype Hanford Barrier Creep Gauge Locations and Elevations (in Meters Above Mean Sea Level) with Differences Between December 1994 and May 2004.

\begin{tabular}{|c|c|c|c|c|c|c|c|c|c|c|c|c|c|c|c|}
\hline \multicolumn{4}{|c|}{ May 14, 2004 Survey } & \multicolumn{6}{|c|}{ Change From Previous Survey (August 15, 2003) } & \multicolumn{6}{|c|}{ Change From First Survey (December 1994) } \\
\hline Gauge \# & Northing & Easting & Elevation & $\Delta \mathbf{N}$ & $\Delta \mathbf{E}$ & $\Delta \mathbf{V}$ & $\begin{array}{c}\text { Horizontal } \\
\text { Resultant }\end{array}$ & $\begin{array}{l}\text { Bearing } \\
\text { Degrees }\end{array}$ & $\begin{array}{l}\text { Bearing } \\
\text { Radians }\end{array}$ & $\Delta \mathbf{N}$ & $\Delta \mathbf{E}$ & $\Delta \mathbf{V}$ & $\begin{array}{l}\text { Horizontal } \\
\text { Resultant }\end{array}$ & $\begin{array}{l}\text { Bearing } \\
\text { Degrees }\end{array}$ & $\begin{array}{l}\text { Bearing } \\
\text { Radians }\end{array}$ \\
\hline 1 & 137535.98 & 573524.43 & 200.30 & -0.006 & 0.013 & 0.073 & 0.015 & 114.25 & 5.86 & -0.004 & 0.050 & 0.077 & 0.050 & 94.52 & 6.20 \\
\hline 2 & 137544.96 & 573525.71 & 200.62 & -0.011 & -0.001 & 0.065 & 0.011 & 184.81 & 4.63 & -0.002 & -0.013 & 0.071 & 0.013 & 262.02 & 3.28 \\
\hline 3 & 137554.18 & 573525.75 & 200.32 & 0.001 & 0.004 & 0.061 & 0.004 & 81.17 & 6.44 & -0.002 & 0.026 & 0.076 & 0.026 & 95.34 & 6.19 \\
\hline 4 & 137563.12 & 573525.86 & 200.36 & 0.005 & 0.011 & 0.068 & 0.013 & 65.31 & 6.71 & 0.028 & 0.025 & 0.073 & 0.038 & 41.97 & 7.12 \\
\hline 5 & 137572.30 & 573525.93 & 200.36 & 0.014 & 0.007 & 0.067 & 0.015 & 26.11 & 7.40 & 0.019 & -0.001 & 0.066 & 0.019 & 355.98 & 1.64 \\
\hline 6 & 137578.01 & 573525.87 & 199.99 & 0.018 & 0.001 & 0.066 & 0.018 & 4.64 & 7.77 & 0.021 & 0.010 & 0.077 & 0.023 & 26.70 & 7.39 \\
\hline 7 & 137583.98 & 573525.55 & 200.26 & 0.013 & -0.004 & 0.065 & 0.014 & 342.72 & 1.87 & 0.013 & -0.017 & 0.070 & 0.022 & 308.08 & 2.48 \\
\hline 8 & 137588.74 & 573525.43 & 200.41 & 0.019 & -0.003 & 0.063 & 0.019 & 351.66 & 1.72 & 0.018 & 0.002 & 0.069 & 0.018 & 7.28 & 7.73 \\
\hline 9 & 137593.21 & 573525.55 & 200.25 & 0.011 & -0.005 & 0.066 & 0.012 & 334.28 & 2.02 & 0.016 & 0.001 & 0.072 & 0.016 & 2.54 & 7.81 \\
\hline $10 \mathrm{a}$ & 137599.10 & 573524.08 & 200.85 & 0.006 & -0.011 & 0.160 & 0.012 & 300.74 & 2.61 & 0.007 & 0.005 & 0.063 & 0.009 & 36.04 & 7.23 \\
\hline $10 \mathrm{~b}$ & 137599.36 & 573526.18 & 199.67 & 0.024 & 0.021 & 0.059 & 0.032 & 41.83 & 7.12 & 0.029 & 0.014 & 0.064 & 0.032 & 26.28 & 7.40 \\
\hline 11 & 137604.96 & 573525.75 & 200.34 & 0.004 & 0.003 & 0.065 & 0.005 & 34.50 & 7.25 & 0.004 & 0.018 & 0.059 & 0.018 & 77.98 & 6.49 \\
\hline 12 & 137518.54 & 573513.22 & 198.96 & 0.001 & 0.002 & 0.107 & 0.002 & 57.02 & 6.86 & 0.011 & -0.013 & 0.060 & 0.017 & 309.78 & 2.45 \\
\hline $13 a$ & 137531.25 & 573524.17 & 200.54 & 0.002 & 0.008 & 0.068 & 0.008 & 72.99 & 6.58 & 0.010 & 0.019 & 0.079 & 0.022 & 61.20 & 6.79 \\
\hline $13 b$ & 137530.56 & 573524.72 & 200.03 & -0.007 & -0.003 & 0.064 & 0.008 & 202.99 & 4.31 & 0.014 & -0.010 & 0.078 & 0.017 & 323.51 & 2.21 \\
\hline
\end{tabular}


Table A.7. Prototype Hanford Barrier New Creep Gauge Locations and Elevations (in Meters Above Mean Sea Level) with Differences Between May 2000 and May 2004

\begin{tabular}{||c|c|c|c|c|c|c|c|c|c|c|c|c|c|c|c||}
\hline \multicolumn{4}{|c|}{ May 14, 2004 Survey } & \multicolumn{3}{c|}{ Change From Previous Survey (August 15, 2003) } & \multicolumn{3}{|c|}{ Change From First Survey (February 07, 2000) } \\
\hline $\begin{array}{c}\text { Gauge } \\
\#\end{array}$ & Northing & Easting & Elevation & D N & D E & D V & $\begin{array}{c}\text { Horizontal } \\
\text { Resultant }\end{array}$ & $\begin{array}{c}\text { Bearing } \\
\text { Degrees }\end{array}$ & $\begin{array}{c}\text { Bearing } \\
\text { Radians }\end{array}$ & D N & D E & D V & $\begin{array}{c}\text { Horizontal } \\
\text { Resultant }\end{array}$ & $\begin{array}{c}\text { Bearing } \\
\text { Degrees }\end{array}$ & $\begin{array}{c}\text { Bearing } \\
\text { Radians }\end{array}$ \\
\hline 12 & 137535.98 & 573524.43 & 200.30 & 0.011 & -0.003 & 0.095 & 0.011 & 346.00 & 0.011 & 1.82 & 0.005 & 0.018 & 0.085 & 0.019 & 74.59 \\
\hline $13 \mathrm{a}$ & 137518.54 & 573513.22 & 198.96 & -0.010 & -0.006 & 0.080 & 0.012 & 212.53 & -0.010 & 4.14 & 0.011 & -0.013 & 0.060 & 0.017 & 309.78 \\
\hline $13 \mathrm{~b}$ & 137531.25 & 573524.17 & 200.54 & 0.021 & -0.017 & 0.089 & 0.027 & 321.62 & 0.021 & 2.24 & 0.010 & 0.019 & 0.079 & 0.022 & 61.20 \\
\hline \hline
\end{tabular}




\section{Appendix B}

Vegetation Survey Measurements Taken at the PROTOTYPE HANFORD BARRIER, 2004 


\section{Appendix B: Vegetation Survey Measurements Taken at the PROTOTYPE HANFORD BARRIER, 2004}

Table B.1. Nonirrigated Shrub Measurements for the Prototype Hanford Barrier, 2003 ...................... B-1

Table B.2. Irrigated Shrub Measurements for the Prototype Hanford Barrier, 2003 …........................ B-2

Table B.3. Percent Canopy Cover on the Prototype Hanford Barrier, 2003 ......................................... B-3

Table B.4. Canopy Cover Distribution on the Prototype Hanford Barrier, 2003. ................................ B-4

Table B.5. Percent Total Canopy Cover on the Prototype Hanford Barrier, 2003 ............................... B-9

B. 1 

Table B.1. Non-Irrigated Shrub Measurements for the Prototype Hanford Barrier, 2004

\begin{tabular}{|c|c|c|c|c|}
\hline Species & Height (cm) & Width (cm) & Length (cm) & Area $\left(\mathrm{cm}^{2}\right)$ \\
\hline Artemisia tridentata (Big sagebrush) & 60 & 77 & 57 & 4,389 \\
\hline Artemisia tridentata (Big sagebrush) & 66 & 86 & 69 & 5,934 \\
\hline Artemisia tridentata (Big sagebrush) & 89 & 104 & 76 & 7,904 \\
\hline Artemisia tridentata (Big sagebrush) & 52 & 42 & 36 & 1,512 \\
\hline Artemisia tridentata (Big sagebrush) & 68 & 64 & 52 & 3,328 \\
\hline Artemisia tridentata (Big sagebrush) & 54 & 42 & 55 & 2,310 \\
\hline Artemisia tridentata (Big sagebrush) & 61 & 106 & 76 & 8,056 \\
\hline Artemisia tridentata (Big sagebrush) & 40 & 55 & 43 & 2,365 \\
\hline Artemisia tridentata (Big sagebrush) & 87 & 98 & 65 & 6,370 \\
\hline Artemisia tridentata (Big sagebrush) & 64 & 87 & 72 & 6,264 \\
\hline Artemisia tridentata (Big sagebrush) & 92 & 82 & 100 & 8,200 \\
\hline Artemisia tridentata (Big sagebrush) & 61 & 80 & 71 & 5,680 \\
\hline Artemisia tridentata (Big sagebrush) & 75 & 59 & 77 & 4,543 \\
\hline Artemisia tridentata (Big sagebrush) & 80 & 102 & 71 & 7,242 \\
\hline Artemisia tridentata (Big sagebrush) & 80 & 90 & 85 & 7,650 \\
\hline Artemisia tridentata (Big sagebrush) & 65 & 85 & 46 & 3,910 \\
\hline Artemisia tridentata (Big sagebrush) & 63 & 56 & 58 & 3,248 \\
\hline Artemisia tridentata (Big sagebrush) & 68 & 63 & 57 & 3,591 \\
\hline Artemisia tridentata (Big sagebrush) & 63 & 50 & 46 & 2,300 \\
\hline Artemisia tridentata (Big sagebrush) & 71 & 62 & 78 & 4,836 \\
\hline Artemisia tridentata (Big sagebrush) & 59 & 72 & 71 & 5,112 \\
\hline Artemisia tridentata (Big sagebrush) & 67 & 55 & 97 & 5,335 \\
\hline Artemisia tridentata (Big sagebrush) & 40 & 24 & 21 & 504 \\
\hline Mean & 66 & 71 & 64 & 4,808 \\
\hline Range & $40-92$ & 24-106 & $21-100$ & $504-8,200$ \\
\hline Minimum & 40 & 24 & 21 & 504 \\
\hline Maximum & 92 & 106 & 100 & 8,200 \\
\hline Chrysothamnus nauseosus (Gray rabbitbrush) & 30 & 34 & 23 & 782 \\
\hline Chrysothamnus nauseosus (Gray rabbitbrush) & 39 & 43 & 20 & 860 \\
\hline Mean & 35 & 39 & 22 & 821 \\
\hline Range & 30-39 & $34-43$ & $20-23$ & $782-860$ \\
\hline Minimum & 30 & 34 & 20 & 782 \\
\hline Maximum & 39 & 43 & 23 & 860 \\
\hline
\end{tabular}


Table B.2. Irrigated Shrub Measurements for the Prototype Hanford Barrier, 2004

\begin{tabular}{|c|c|c|c|c|}
\hline Species & Height (cm) & Width (cm) & Length (cm) & Area $\left(\mathrm{cm}^{2}\right)$ \\
\hline Artemisia tridentata (Big sagebrush) & 78 & 50 & 115 & 5,750 \\
\hline Artemisia tridentata (Big sagebrush) & 72 & 65 & 67 & 4,355 \\
\hline Artemisia tridentata (Big sagebrush) & 30 & 23 & 27 & 621 \\
\hline Artemisia tridentata (Big sagebrush) & 65 & 54 & 77 & 4,158 \\
\hline Artemisia tridentata (Big sagebrush) & 73 & 88 & 94 & 8,272 \\
\hline Artemisia tridentata (Big sagebrush) & 75 & 66 & 87 & 5,742 \\
\hline Artemisia tridentata (Big sagebrush) & 86 & 57 & 90 & 5,130 \\
\hline Artemisia tridentata (Big sagebrush) & 61 & 43 & 66 & 2,838 \\
\hline Artemisia tridentata (Big sagebrush) & 84 & 49 & 52 & 2,548 \\
\hline Artemisia tridentata (Big sagebrush) & 53 & 52 & 76 & 3,952 \\
\hline Artemisia tridentata (Big sagebrush) & 42 & 5 & 74 & 370 \\
\hline Artemisia tridentata (Big sagebrush) & 94 & 62 & 70 & 4,340 \\
\hline Artemisia tridentata (Big sagebrush) & 54 & 66 & 81 & 5,346 \\
\hline Artemisia tridentata (Big sagebrush) & 69 & 52 & 75 & 3,900 \\
\hline Artemisia tridentata (Big sagebrush) & 77 & 54 & 67 & 3,618 \\
\hline Artemisia tridentata (Big sagebrush) & 118 & 112 & 138 & 15,456 \\
\hline Artemisia tridentata (Big sagebrush) & 37 & 24 & 64 & 1,536 \\
\hline Artemisia tridentata (Big sagebrush) & 68 & 35 & 66 & 2,310 \\
\hline Artemisia tridentata (Big sagebrush) & 80 & 76 & 93 & 7,068 \\
\hline Artemisia tridentata (Big sagebrush) & 70 & 26 & 64 & 1,664 \\
\hline Mean & 69 & 53 & 77 & 4,449 \\
\hline Range & $30-118$ & $5-112$ & $27-138$ & $370-15,456$ \\
\hline Minimum & 30 & 5 & 27 & 370 \\
\hline Maximum & 118 & 112 & 138 & 15,456 \\
\hline Chrysothamnus nauseosus (Gray rabbitbrush) & 45 & 58 & 64 & 3,712 \\
\hline Chrysothamnus nauseosus (Gray rabbitbrush) & 68 & 40 & 83 & 3,320 \\
\hline Chrysothamnus nauseosus (Gray rabbitbrush) & 38 & 17 & 40 & 680 \\
\hline Chrysothamnus nauseosus (Gray rabbitbrush) & 62 & 94 & 97 & 9,118 \\
\hline Chrysothamnus nauseosus (Gray rabbitbrush) & 57 & 26 & 45 & 1,170 \\
\hline Mean & 54 & 47 & 66 & 3,600 \\
\hline Range & $38-68$ & $17-94$ & 40-97 & $680-9,118$ \\
\hline Minimum & 38 & 17 & 40 & 680 \\
\hline Maximum & 68 & 94 & 97 & 9,118 \\
\hline
\end{tabular}


Table B.3. Percent Canopy Cover on the Prototype Hanford Barrier, 2004

\begin{tabular}{||l|c|c|c|c||}
\hline Measurement & Grass & Shrub & Litter & $\begin{array}{c}\text { Bare } \\
\text { Ground }\end{array}$ \\
\hline \multicolumn{5}{|c||}{ Irrigated } \\
\hline Mean & 28.8 & 36.8 & 48.2 & 45.7 \\
\hline Median & 15.0 & 37.5 & 50.0 & 37.5 \\
\hline Mode & 15.0 & 37.5 & 62.5 & 62.5 \\
\hline \multicolumn{5}{|c|}{ Non-Irrigated } \\
\hline Mean & 17.3 & 33.8 & 29.1 & 55.1 \\
\hline Median & 2.5 & 37.5 & 37.5 & 62.5 \\
\hline Mode & 2.5 & 37.5 & 37.5 & 62.5 \\
\hline \hline
\end{tabular}

$\begin{array}{ccc}\text { Class } & \text { Percent Cover } & \text { Midpoint } \\ 1 & 0 \text { to } 5 & 2.5 \\ 2 & 5 \text { to } 25 & 15 \\ 3 & 25 \text { to } 50 & 37.5 \\ 4 & 50 \text { to } 75 & 62.5 \\ 5 & 75 \text { to } 95 & 85 \\ 6 & 95 \text { to } 100 & 97.5\end{array}$


Table B.4. Canopy Cover Distribution on the Prototype Hanford Barrier, 2004 (1 of 4)

\begin{tabular}{|c|c|c|c|c|c|c|c|c|c|c|c|c|c|}
\hline \multicolumn{14}{|c|}{ Grass } \\
\hline & Row & 1 & 2 & 3 & 4 & 5 & 6 & 7 & 8 & 9 & 10 & 11 & 12 \\
\hline \multirow{11}{*}{$\begin{array}{c}\mathbf{I} \\
\mathbf{R} \\
\mathbf{R} \\
\mathbf{I} \\
\mathbf{G} \\
\mathbf{A} \\
\mathbf{T} \\
\mathbf{E} \\
\mathbf{D}\end{array}$} & 25 & 85 & 62.5 & 62.5 & 85 & 85 & 37.5 & 15 & 85 & 85 & 62.5 & 62.5 & 37.5 \\
\hline & 24 & 62.5 & 62.5 & 62.5 & 62.5 & 15 & 15 & 15 & 15 & 37.5 & 85 & 85 & 62.5 \\
\hline & 23 & 37.5 & 15 & 15 & 15 & 15 & 2.5 & 2.5 & 15 & 15 & 62.5 & 85 & 62.5 \\
\hline & 22 & 37.5 & 2.5 & 37.5 & 15 & 15 & 2.5 & 15 & 37.5 & 15 & 37.5 & 85 & 37.5 \\
\hline & 21 & 37.5 & 15 & 15 & 37.5 & 15 & 2.5 & 2.5 & 15 & 15 & 37.5 & 62.5 & 37.5 \\
\hline & 20 & 37.5 & 37.5 & 15 & 15 & 2.5 & 2.5 & 2.5 & 2.5 & 15 & 37.5 & 37.5 & 37.5 \\
\hline & 19 & 62.5 & 37.5 & 15 & 2.5 & 2.5 & 2.5 & 15 & 37.5 & 62.5 & 37.5 & 37.5 & 37.5 \\
\hline & 18 & 37.5 & 15 & 15 & 2.5 & 2.5 & 2.5 & 2.5 & 15 & 15 & 15 & 37.5 & 15 \\
\hline & 17 & 62.5 & 15 & 15 & 15 & 15 & 15 & 15 & 2.5 & 2.5 & 2.5 & 15 & 15 \\
\hline & 16 & 15 & 15 & 15 & 15 & 2.5 & 2.5 & 2.5 & 15 & 15 & 15 & 37.5 & 37.5 \\
\hline & 15 & 37.5 & 15 & 15 & 2.5 & 2.5 & 2.5 & 37.5 & 2.5 & 37.5 & 62.5 & 62.5 & 62.5 \\
\hline \multirow{14}{*}{$\begin{array}{l}\mathbf{N} \\
\mathbf{O} \\
\mathbf{N} \\
\mathbf{I} \\
\mathbf{R} \\
\mathbf{R} \\
\mathbf{I} \\
\mathbf{G} \\
\mathbf{A} \\
\mathbf{T} \\
\mathbf{E} \\
\mathbf{D}\end{array}$} & 14 & 15 & 2.5 & 2.5 & 2.5 & 2.5 & 2.5 & 2.5 & 15 & 2.5 & 2.5 & 2.5 & 37.5 \\
\hline & 13 & 15 & 2.5 & 2.5 & 15 & 2.5 & 2.5 & 2.5 & 15 & 2.5 & 2.5 & 2.5 & 37.5 \\
\hline & 12 & 37.5 & 2.5 & 2.5 & 2.5 & 2.5 & 15 & 2.5 & 2.5 & 2.5 & 15 & 15 & 15 \\
\hline & 11 & 2.5 & 15 & 15 & 15 & 2.5 & 2.5 & 2.5 & 15 & 15 & 15 & 37.5 & 15 \\
\hline & 10 & 15 & 62.5 & 62.5 & 85 & 85 & 85 & 62.5 & 37.5 & 62.5 & 62.5 & 15 & 62.5 \\
\hline & 9 & 62.5 & 15 & 2.5 & 2.5 & 2.5 & 2.5 & 2.5 & 15 & 2.5 & 2.5 & 15 & 15 \\
\hline & 8 & 15 & 2.5 & 2.5 & 2.5 & 2.5 & 2.5 & 2.5 & 2.5 & 15 & 2.5 & 15 & 15 \\
\hline & 7 & 15 & 2.5 & 2.5 & 2.5 & 2.5 & 2.5 & 2.5 & 2.5 & 2.5 & 2.5 & 15 & 37.5 \\
\hline & 6 & 15 & 15 & 2.5 & 62.5 & 15 & 85 & 85 & 62.5 & 62.5 & 15 & 37.5 & 37.5 \\
\hline & 5 & 37.5 & 2.5 & 2.5 & 2.5 & 2.5 & 2.5 & 2.5 & 2.5 & 2.5 & 15 & 15 & 37.5 \\
\hline & 4 & 15 & 15 & 2.5 & 2.5 & 2.5 & 2.5 & 2.5 & 2.5 & 2.5 & 2.5 & 2.5 & 2.5 \\
\hline & 3 & 37.5 & 15 & 2.5 & 2.5 & 2.5 & 2.5 & 2.5 & 2.5 & 2.5 & 2.5 & 15 & 37.5 \\
\hline & 2 & 37.5 & 15 & 15 & 2.5 & 2.5 & 2.5 & 2.5 & 2.5 & 2.5 & 15 & 15 & 37.5 \\
\hline & 1 & 15 & 15 & 2.5 & 62.5 & 15 & 85 & 85 & 62.5 & 62.5 & 15 & 37.5 & 37.5 \\
\hline
\end{tabular}

B.6 
Table B.4. Canopy Cover Distribution on the Prototype Hanford Barrier, 2004 (2 of 4)

\begin{tabular}{|c|c|c|c|c|c|c|c|c|c|c|c|c|c|}
\hline \multicolumn{14}{|c|}{ Shrubs } \\
\hline & Row & 1 & 2 & 3 & 4 & 5 & 6 & 7 & 8 & 9 & 10 & 11 & 12 \\
\hline \multirow{11}{*}{$\begin{array}{c}\mathbf{I} \\
\mathbf{R} \\
\mathbf{R} \\
\mathbf{I} \\
\mathbf{G} \\
\mathbf{A} \\
\mathbf{T} \\
\mathbf{E} \\
\mathbf{D}\end{array}$} & 25 & 62.5 & 15 & 15 & 15 & 37.5 & 37.5 & 37.5 & 15 & 15 & 2.5 & 15 & 15 \\
\hline & 24 & 37.5 & 37.5 & 37.5 & 62.5 & 62.5 & 37.5 & 37.5 & 37.5 & 15 & 2.5 & 2.5 & 15 \\
\hline & 23 & 37.5 & 62.5 & 15 & 37.5 & 15 & 37.5 & 37.5 & 37.5 & 15 & 37.5 & 2.5 & 15 \\
\hline & 22 & 62.5 & 62.5 & 37.5 & 62.5 & 37.5 & 37.5 & 15 & 62.5 & 37.5 & 37.5 & 37.5 & 37.5 \\
\hline & 21 & 62.5 & 62.5 & 15 & 62.5 & 62.5 & 37.5 & 37.5 & 37.5 & 15 & 37.5 & 62.5 & 15 \\
\hline & 20 & 62.5 & 37.5 & 37.5 & 37.5 & 62.5 & 15 & 62.5 & 37.5 & 37.5 & 37.5 & 15 & 37.5 \\
\hline & 19 & 62.5 & 37.5 & 37.5 & 37.5 & 37.5 & 37.5 & 37.5 & 37.5 & 15 & 15 & 37.5 & 62.5 \\
\hline & 18 & 37.5 & 37.5 & 62.5 & 37.5 & 15 & 37.5 & 37.5 & 37.5 & 62.5 & 62.5 & 15 & 15 \\
\hline & 17 & 37.5 & 37.5 & 37.5 & 15 & 15 & 37.5 & 15 & 37.5 & 15 & 37.5 & 37.5 & 62.5 \\
\hline & 16 & 62.5 & 15 & 62.5 & 15 & 37.5 & 37.5 & 62.5 & 62.5 & 62.5 & 37.5 & 37.5 & 62.5 \\
\hline & 15 & 37.5 & 62.5 & 62.5 & 37.5 & 37.5 & 2.5 & 15 & 62.5 & 15 & 37.5 & 37.5 & 62.5 \\
\hline \multirow{14}{*}{$\begin{array}{c}\mathbf{N} \\
\mathbf{O} \\
\mathbf{N} \\
\mathbf{I} \\
\mathbf{R} \\
\mathbf{R} \\
\mathbf{I} \\
\mathbf{G} \\
\mathbf{A} \\
\mathbf{T} \\
\mathbf{E} \\
\mathbf{D}\end{array}$} & 14 & 62.5 & 15 & 37.5 & 37.5 & 37.5 & 15 & 15 & 37.5 & 15 & 37.5 & 37.5 & 37.5 \\
\hline & 13 & 62.5 & 37.5 & 37.5 & 37.5 & 15 & 37.5 & 37.5 & 37.5 & 37.5 & 62.5 & 15 & 62.5 \\
\hline & 12 & 15 & 37.5 & 15 & 37.5 & 37.5 & 37.5 & 15 & 37.5 & 15 & 37.5 & 37.5 & 62.5 \\
\hline & 11 & 37.5 & 37.5 & 37.5 & 37.5 & 37.5 & 15 & 37.5 & 62.5 & 37.5 & 37.5 & 37.5 & 37.5 \\
\hline & 10 & 37.5 & 15 & 2.5 & 15 & 2.5 & 2.5 & 2.5 & 15 & 2.5 & 15 & 15 & 15 \\
\hline & 9 & 37.5 & 62.5 & 37.5 & 37.5 & 37.5 & 15 & 15 & 37.5 & 15 & 37.5 & 37.5 & 37.5 \\
\hline & 8 & 62.5 & 15 & 37.5 & 37.5 & 62.5 & 37.5 & 37.5 & 37.5 & 37.5 & 15 & 15 & 15 \\
\hline & 7 & 62.5 & 37.5 & 15 & 37.5 & 37.5 & 37.5 & 37.5 & 15 & 37.5 & 37.5 & 37.5 & 15 \\
\hline & 6 & 15 & 37.5 & 37.5 & 37.5 & 15 & 62.5 & 37.5 & 37.5 & 37.5 & 37.5 & 15 & 62.5 \\
\hline & 5 & 37.5 & 15 & 15 & 37.5 & 15 & 37.5 & 37.5 & 37.5 & 15 & 15 & 37.5 & 37.5 \\
\hline & 4 & 62.5 & 37.5 & 37.5 & 15 & 62.5 & 37.5 & 37.5 & 15 & 37.5 & 37.5 & 15 & 37.5 \\
\hline & 3 & 37.5 & 37.5 & 62.5 & 15 & 37.5 & 37.5 & 15 & 15 & 37.5 & 15 & 15 & 15 \\
\hline & 2 & 37.5 & 62.5 & 62.5 & 15 & 62.5 & 37.5 & 62.5 & 62.5 & 62.5 & 62.5 & 85 & 15 \\
\hline & 1 & 15 & 37.5 & 37.5 & 37.5 & 15 & 62.5 & 37.5 & 37.5 & 37.5 & 37.5 & 15 & 62.5 \\
\hline
\end{tabular}

B. 7 
Table B.4. Cover Distribution on the Prototype Hanford Barrier, 2004 (3 of 4)

\begin{tabular}{|c|c|c|c|c|c|c|c|c|c|c|c|c|c|}
\hline \multicolumn{14}{|c|}{ Litter } \\
\hline & Row & 1 & 2 & 3 & 4 & 5 & 6 & 7 & 8 & 9 & 10 & 11 & 12 \\
\hline \multirow{11}{*}{$\begin{array}{c}\mathbf{I} \\
\mathbf{R} \\
\mathbf{R} \\
\mathbf{I} \\
\mathbf{G} \\
\mathbf{A} \\
\mathbf{T} \\
\mathbf{E} \\
\mathbf{D}\end{array}$} & 25 & 37.5 & 62.5 & 85 & 85 & 85 & 37.5 & 15 & 85 & 85 & 97.5 & 97.5 & 62.5 \\
\hline & 24 & 85 & 85 & 62.5 & 62.5 & 15 & 37.5 & 15 & 37.5 & 37.5 & 85 & 97.5 & 85 \\
\hline & 23 & 62.5 & 15 & 15 & 62.5 & 15 & 15 & 2.5 & 15 & 15 & 85 & 97.5 & 62.5 \\
\hline & 22 & 62.5 & 62.5 & 62.5 & 62.5 & 37.5 & 37.5 & 37.5 & 37.5 & 37.5 & 37.5 & 85 & 62.5 \\
\hline & 21 & 62.5 & 37.5 & 37.5 & 62.5 & 37.5 & 15 & 15 & 37.5 & 15 & 37.5 & 62.5 & 62.5 \\
\hline & 20 & 62.5 & 62.5 & 15 & 62.5 & 15 & 15 & 2.5 & 15 & 62.5 & 37.5 & 62.5 & 62.5 \\
\hline & 19 & 62.5 & 62.5 & 37.5 & 15 & 15 & 15 & 37.5 & 37.5 & 62.5 & 62.5 & 62.5 & 62.5 \\
\hline & 18 & 85 & 62.5 & 15 & 37.5 & 37.5 & 15 & 37.5 & 62.5 & 37.5 & 37.5 & 85 & 37.5 \\
\hline & 17 & 85 & 85 & 62.5 & 37.5 & 37.5 & 37.5 & 37.5 & 62.5 & 15 & 62.5 & 62.5 & 62.5 \\
\hline & 16 & 62.5 & 62.5 & 15 & 15 & 15 & 2.5 & 15 & 62.5 & 62.5 & 62.5 & 85 & 85 \\
\hline & 15 & 85 & 37.5 & 37.5 & 15 & 15 & 15 & 15 & 37.5 & 62.5 & 62.5 & 62.5 & 62.5 \\
\hline \multirow{14}{*}{$\begin{array}{l}\mathbf{N} \\
\mathbf{O} \\
\mathbf{N} \\
\mathbf{I} \\
\mathbf{R} \\
\mathbf{R}\end{array}$} & 14 & 15 & 62.5 & 37.5 & 37.5 & 2.5 & 2.5 & 2.5 & 37.5 & 37.5 & 15 & 37.5 & 37.5 \\
\hline & 13 & 37.5 & 37.5 & 15 & 37.5 & 2.5 & 15 & 15 & 2.5 & 15 & 37.5 & 62.5 & 62.5 \\
\hline & 12 & 37.5 & 37.5 & 2.5 & 15 & 15 & 15 & 2.5 & 15 & 15 & 37.5 & 15 & 62.5 \\
\hline & 11 & 62.5 & 37.5 & 37.5 & 2.5 & 2.5 & 2.5 & 15 & 15 & 15 & 37.5 & 37.5 & 15 \\
\hline & 10 & 62.5 & 37.5 & 62.5 & 15 & 15 & 37.5 & 37.5 & 62.5 & 15 & 37.5 & 37.5 & 37.5 \\
\hline & 9 & 37.5 & 62.5 & 2.5 & 2.5 & 15 & 15 & 37.5 & 62.5 & 15 & 15 & 62.5 & 37.5 \\
\hline & 8 & 37.5 & 37.5 & 15 & 2.5 & 37.5 & 15 & 15 & 2.5 & 15 & 15 & 2.5 & 2.5 \\
\hline & 7 & 37.5 & 37.5 & 15 & 15 & 15 & 15 & 37.5 & 15 & 37.5 & 62.5 & 15 & 15 \\
\hline & 6 & 62.5 & 37.5 & 62.5 & 15 & 2.5 & 15 & 15 & 37.5 & 62.5 & 62.5 & 37.5 & 37.5 \\
\hline & 5 & 62.5 & 37.5 & 15 & 2.5 & 2.5 & 2.5 & 37.5 & 15 & 37.5 & 15 & 15 & 62.5 \\
\hline & 4 & 37.5 & 15 & 37.5 & 15 & 2.5 & 2.5 & 15 & 15 & 37.5 & 62.5 & 15 & 37.5 \\
\hline & 3 & 37.5 & 37.5 & 37.5 & 62.5 & 2.5 & 37.5 & 15 & 15 & 15 & 37.5 & 2.5 & 62.5 \\
\hline & 2 & 37.5 & 62.5 & 62.5 & 37.5 & 62.5 & 2.5 & 15 & 37.5 & 37.5 & 62.5 & 37.5 & 37.5 \\
\hline & 1 & 62.5 & 37.5 & 62.5 & 15 & 2.5 & 15 & 15 & 37.5 & 62.5 & 62.5 & 37.5 & 37.5 \\
\hline
\end{tabular}

B. 8 
Table B.4. Canopy Cover Distribution on the Prototype Hanford Barrier, 2004. (4 of 4)

\begin{tabular}{|c|c|c|c|c|c|c|c|c|c|c|c|c|c|}
\hline \multicolumn{14}{|c|}{ Bare Ground } \\
\hline & Row & 1 & 2 & 3 & 4 & 5 & 6 & 7 & 8 & 9 & 10 & 11 & 12 \\
\hline \multirow{11}{*}{$\begin{array}{c}\text { I } \\
\text { R } \\
\text { R } \\
\text { I } \\
\text { G } \\
\text { A } \\
\text { T } \\
\text { E } \\
\text { D }\end{array}$} & 25 & 2.5 & 15 & 15 & 15 & 15 & 62.5 & 62.5 & 15 & 15 & 2.5 & 2.5 & 15 \\
\hline & 24 & 15 & 2.5 & 37.5 & 15 & 85 & 85 & 97.5 & 62.5 & 62.5 & 37.5 & 2.5 & 15 \\
\hline & 23 & 62.5 & 62.5 & 85 & 85 & 85 & 62.5 & 85 & 85 & 62.5 & 2.5 & 2.5 & 37.5 \\
\hline & 22 & 15 & 37.5 & 37.5 & 37.5 & 62.5 & 62.5 & 62.5 & 37.5 & 62.5 & 37.5 & 2.5 & 37.5 \\
\hline & 21 & 37.5 & 62.5 & 62.5 & 37.5 & 62.5 & 62.5 & 85 & 62.5 & 62.5 & 62.5 & 15 & 37.5 \\
\hline & 20 & 15 & 37.5 & 62.5 & 62.5 & 62.5 & 85 & 62.5 & 62.5 & 62.5 & 62.5 & 37.5 & 37.5 \\
\hline & 19 & 15 & 15 & 62.5 & 85 & 85 & 85 & 62.5 & 37.5 & 37.5 & 15 & 15 & 15 \\
\hline & 18 & 15 & 15 & 62.5 & 62.5 & 62.5 & 85 & 62.5 & 37.5 & 37.5 & 37.5 & 15 & 62.5 \\
\hline & 17 & 15 & 15 & 37.5 & 62.5 & 85 & 62.5 & 85 & 37.5 & 85 & 15 & 15 & 15 \\
\hline & 16 & 15 & 85 & 85 & 85 & 62.5 & 85 & 62.5 & 15 & 37.5 & 37.5 & 15 & 15 \\
\hline & 15 & 15 & 37.5 & 62.5 & 85 & 85 & 85 & 85 & 15 & 37.5 & 15 & 15 & 15 \\
\hline \multirow{14}{*}{$\begin{array}{l}\mathbf{N} \\
\mathbf{O} \\
\mathbf{N} \\
\mathbf{I} \\
\mathbf{R} \\
\mathbf{R} \\
\mathbf{I} \\
\mathbf{G} \\
\mathbf{A} \\
\mathbf{T} \\
\mathbf{E} \\
\mathbf{D}\end{array}$} & 14 & 62.5 & 37.5 & 37.5 & 62.5 & 85 & 85 & 85 & 62.5 & 37.5 & 37.5 & 62.5 & 37.5 \\
\hline & 13 & 37.5 & 62.5 & 62.5 & 62.5 & 85 & 85 & 62.5 & 62.5 & 85 & 62.5 & 62.5 & 15 \\
\hline & 12 & 37.5 & 62.5 & 85 & 85 & 85 & 62.5 & 85 & 85 & 62.5 & 62.5 & 62.5 & 15 \\
\hline & 11 & 15 & 62.5 & 62.5 & 85 & 85 & 85 & 37.5 & 62.5 & 62.5 & 37.5 & 62.5 & 62.5 \\
\hline & 10 & 37.5 & 62.5 & 15 & 37.5 & 62.5 & 62.5 & 37.5 & 62.5 & 62.5 & 37.5 & 62.5 & 62.5 \\
\hline & 9 & 15 & 15 & 62.5 & 85 & 85 & 85 & 85 & 62.5 & 85 & 62.5 & 37.5 & 62.5 \\
\hline & 8 & 37.5 & 37.5 & 62.5 & 62.5 & 62.5 & 62.5 & 62.5 & 85 & 85 & 85 & 37.5 & 62.5 \\
\hline & 7 & 15 & 37.5 & 62.5 & 85 & 62.5 & 85 & 62.5 & 62.5 & 62.5 & 37.5 & 37.5 & 62.5 \\
\hline & 6 & 15 & 62.5 & 37.5 & 85 & 85 & 62.5 & 62.5 & 37.5 & 15 & 37.5 & 37.5 & 15 \\
\hline & 5 & 15 & 62.5 & 62.5 & 62.5 & 85 & 62.5 & 62.5 & 62.5 & 37.5 & 85 & 62.5 & 37.5 \\
\hline & 4 & 37.5 & 62.5 & 37.5 & 62.5 & 62.5 & 85 & 62.5 & 62.5 & 37.5 & 15 & 62.5 & 62.5 \\
\hline & 3 & 15 & 62.5 & 62.5 & 62.5 & 37.5 & 62.5 & 62.5 & 62.5 & 62.5 & 85 & 15 & 15 \\
\hline & 2 & 15 & 15 & 2.5 & 62.5 & 15 & 85 & 85 & 62.5 & 62.5 & 15 & 37.5 & 37.5 \\
\hline & 1 & 15 & 62.5 & 37.5 & 85 & 85 & 62.5 & 62.5 & 37.5 & 15 & 37.5 & 37.5 & 15 \\
\hline
\end{tabular}


Table B.5. Percent Total Canopy Cover on the Prototype Hanford Barrier, 2004

\begin{tabular}{|c|c|c|c|c|c|}
\hline & Row & $\begin{array}{c}\text { Bare } \\
\text { Ground }\end{array}$ & Grass & Litter & Shrub \\
\hline \multirow{12}{*}{$\begin{array}{c}\mathbf{I} \\
\mathbf{R} \\
\mathbf{R} \\
\mathbf{I} \\
\mathbf{G} \\
\mathbf{A} \\
\mathbf{T} \\
\mathbf{E} \\
\mathbf{D}\end{array}$} & 25 & 19.8 & 63.8 & 69.6 & 23.5 \\
\hline & 24 & 43.1 & 48.3 & 58.8 & 32.1 \\
\hline & 23 & 59.8 & 28.5 & 38.5 & 29.2 \\
\hline & 22 & 41.0 & 28.1 & 51.9 & 44.0 \\
\hline & 21 & 54.2 & 24.4 & 40.2 & 42.3 \\
\hline & 20 & 54.2 & 20.2 & 39.6 & 40.0 \\
\hline & 19 & 44.2 & 29.2 & 44.4 & 37.9 \\
\hline & 18 & 46.3 & 14.6 & 45.8 & 38.1 \\
\hline & 17 & 44.2 & 15.8 & 54.0 & 32.1 \\
\hline & 16 & 50.0 & 15.6 & 45.4 & 46.3 \\
\hline & 15 & 46.0 & 28.3 & 42.3 & 39.2 \\
\hline & MEAN & 45.7 & 28.8 & 48.2 & 36.8 \\
\hline \multirow{15}{*}{$\begin{array}{l}\mathbf{N} \\
\mathbf{O} \\
\mathbf{N} \\
\mathbf{I} \\
\mathbf{R} \\
\mathbf{R} \\
\mathbf{I} \\
\mathbf{G} \\
\mathbf{A} \\
\mathbf{T} \\
\mathbf{E} \\
\mathbf{D}\end{array}$} & 14 & 57.7 & 7.5 & 27.1 & 32.1 \\
\hline & 13 & 62.1 & 8.5 & 28.3 & 40.0 \\
\hline & 12 & 65.8 & 9.6 & 22.5 & 32.1 \\
\hline & 11 & 60.0 & 12.7 & 23.3 & 37.7 \\
\hline & 10 & 50.2 & 58.1 & 38.1 & 11.7 \\
\hline & 9 & 61.9 & 11.7 & 30.4 & 34.0 \\
\hline & 8 & 61.9 & 6.7 & 16.5 & 34.2 \\
\hline & 7 & 56.0 & 7.5 & 26.5 & 34.0 \\
\hline & 6 & 46.0 & 41.3 & 37.1 & 36.0 \\
\hline & 5 & 58.1 & 10.4 & 25.4 & 28.1 \\
\hline & 4 & 54.2 & 4.6 & 24.4 & 36.0 \\
\hline & 3 & 50.4 & 10.4 & 30.2 & 28.3 \\
\hline & 2 & 41.3 & 12.5 & 41.0 & 52.3 \\
\hline & 1 & 46.0 & 41.3 & 37.1 & 36.0 \\
\hline & MEAN & 55.1 & 17.3 & 29.1 & 33.8 \\
\hline
\end{tabular}

B. 10 


\section{Distribution}

No. of

Copies

ONSITE

3 U.S. Department of Energy-Richland Operations

Bryan Foley

A6-38

Kevin Leary

A6-38

DOE Public Reading Room

$\mathrm{H} 2-53$

2 Lockheed Martin Information Technology Central Files

B1-07

Document Processing Center

A3-94

10 CH2M Hill Hanford, Inc.

Jenifer Linville

$\mathrm{H} 0-23$

Frank Anderson

E6-35

William McMahon

E6-35

Chris Kemp

R1-51

Terry Sams

H6-05

Curtis Wittreich (5)

H6-62
No. of

Copies

ONSITE

5 Fluor Hanford, Inc.

Scott Petersen E6-35

Tom Fogwell E6-35

Bruce Ford E6-35

Mary Todd E6-35

Ron Jackson E6-35

9 Pacific Northwest National Laboratory

Mike Fayer

K9-33

Glendon Gee

K9-33

Andy Ward (5)

K9-33

Hanford Technical Library (2) P8-55 